\title{
AVALIAÇÃO DA OCORRÊNCIA E DO TRANSPORTE DE MICRORGANISMOS NO AQÜÍFERO FREÁTICO DO CEMITÉRIO DE VILA NOVA CACHOEIRINHA, MUNICÍPIO DE SÃO PAULO
}

Bolivar Antunes Matos

Orientador: Prof. Dr. Alberto Pacheco

TESE DE DOUTORAMENTO

Programa de Pós-Graduação em Recursos Minerais e Hidrogeologia

SÃO PAULO 
Aos meus pais Evódio e Jaci Antunes;

aos meus irmãos Ivete, Hussein e Ian;

e à minha sobrinha Lais. 


\section{AGRADECIMENTOS}

Ao Prof. Dr. Alberto Pacheco, que foi muito além da orientação acadêmica. Sou-lhe imensamente grato por compartilhar sua experiência, pelo incentivo a este projeto e à minha vida profissional;

À Profa. Dra. Vívian Pellizari e aos colegas do Laboratório de Microbiologia Ambiental do Instituto de Ciências Biomédicas da USP, pela dedicação a este projeto. À Profa. Dra. Dolores Mehnert e ao Laboratório de Virologia do Instituto de Ciências Biomédicas da USP, pelas sugestões, coleta e análise das amostras;

Ao saudoso Prof. Dr. José Milton Mendes, pela orientação nos estudos de geofísica;

Aos professores doutores Dorothy Casarini, Itabaraci Cavalcante, João Manoel Filho, Jorge Kazuo Yamamoto, Raphael Hypólito, Ricardo Hirata e Uriel Duarte, pela colaboração, incentivo e sugestões valiosas;

Ao mestre Manoel Conejo Lopes, pela revisão e sugestões ao texto. Aos doutores Mara Iritani e Seiju Hassuda, pela colaboração e sugestões;

Aos técnicos da USP Elaine Sinfrônio, Lúcia Helena da Silva, Natália Oliveira e Rosa Gamba, pelas sugestões, coleta e análise das amostras. Aos técnicos da USP Cláudio dos Santos, Sérgio Martins e Sílvio Pereira, pela confecção e instalação de equipamentos. À bibliotecária Maristela Prestes Severino, pela revisão das referências bibliográficas;

Aos colegas Débora Rodrigues, Jamile Dehaini, Rosângela Oliveira, Douglas Bastianon e Édson Batello, pelos esforços e dedicação ao projeto. Aos colegas Aimar Nicoletto, Alexandre Maximiano, Rodrigo Espíndola, Lezíro Silva e Wagner Aquino, pela contribuição;

Aos funcionários do Serviço Funerário do Município de São Paulo Cláudio Vergnianini, Fábio Leite de Oliveira, Israel dos Santos e Luis Carlos Leite, pela colaboração;

Ao Prof. Antônio Santos Oliveira, pela revisão do texto;

À Universidade de São Paulo, pela infraestrutura colocada à disposição, em particular, o Centro de Pesquisas de Águas Subterrâneas (CEPAS), o Laboratório de Sedimentologia, o Laboratório de Difratometria de Raio X e o Laboratório de Fluorescência do Instituto de Geociências; o Laboratório de Engenharia de Transportes da Escola Politécnica; o Laboratório de Solos da Escola Luiz de Queiroz;

À Companhia de Tecnologia de Saneamento Ambiental (CETESB), por parte dos estudos de geofísica. À Secretaria Municipal do Verde e do Meio Ambiente de São Paulo, pelo apoio institucional;

À Fundação de Amparo à Pesquisa do Estado de São Paulo (FAPESP), que viabilizou a execução do projeto e ao Conselho Nacional de Desenvolvimento Científico e Tecnológico $(\mathrm{CNPq})$, pelo apoio financeiro ao pesquisador;

Ao Dr. Fábio José Guida, pela revisão do texto. Aos amigos Ilce Campos e Sílvio Rodrigues de Oliveira, pelo apoio;

Aos meus estimados parentes Geralda e Clodoves Araújo, Sílvia e Humberto Marchina, Sélida e Ariosto Lima, Luíza e Galber Araújo, Valda e Antônio Lima, pela maneira carinhosa como me acolheram em São Paulo;

Aos meus amados pais e irmãos, pelo apoio, tolerância e paciência, durante a minha ausência. 
(Nossa Senhora da Luz)

Nesta terra ninguém jaz, pois também não jaz um rio noutro rio, nem o mar é cemitério de rios.

Nenhum dos mortos daqui vem vestido de caixão. Portanto, eles não se enterram, são derramados no chão.

Vêm em redes de varandas abertas ao sol e à chuva. Trazem suas próprias moscas. O chão lhes vai como luva.

Mortos ao ar-livre, que eram, hoje à terra-livre estão. São tão da terra que a terra nem sente sua intrusão.

Em Cemitério Pernambucano de João Cabral de Melo Neto 


\section{SUMÁRIO}

LISTA DE FIGURAS …............................................................................................ VIII

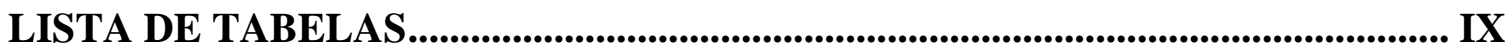

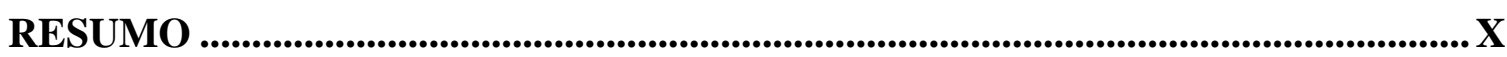

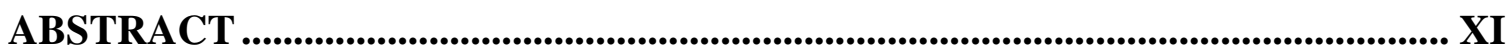

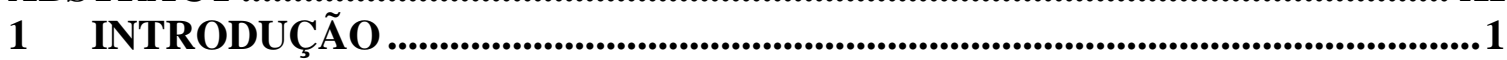

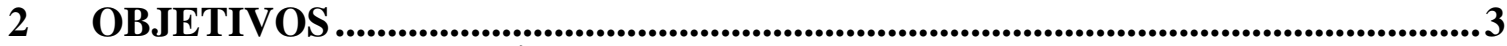

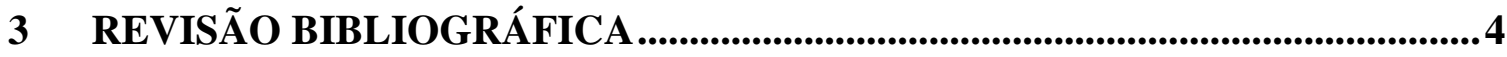

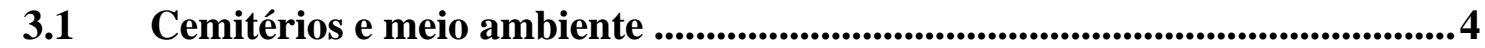

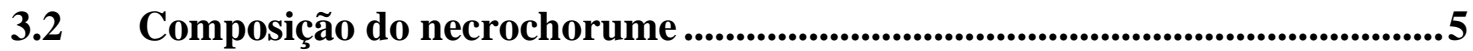

3.3 Fenômenos transformativos .....................................................................7

3.4 Agentes causadores de doenças de veiculação hídrica ..................................8

3.5 Sobrevivência de microrganismos ..................................................................10

3.6 Transporte de microrganismos ...........................................................10

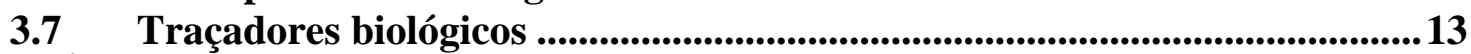

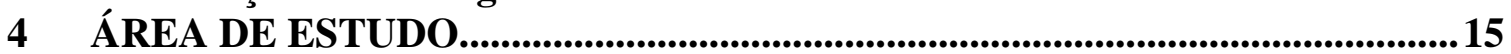

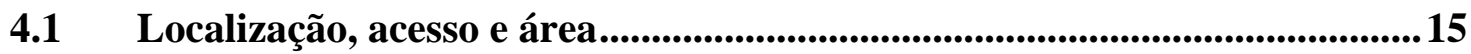

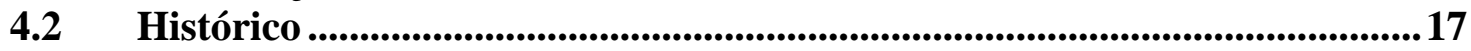

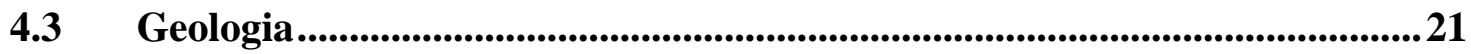

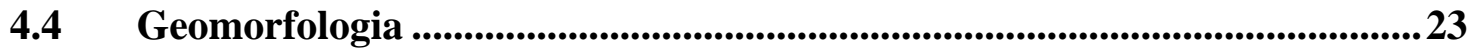

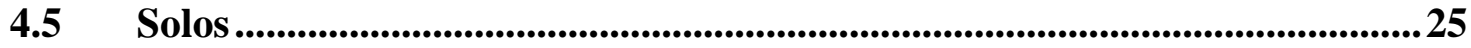

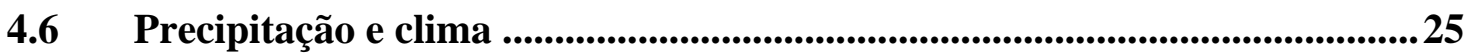

4.7 Bacia hidrográfica ......................................................................................... 27

4.8 Águas subterrâneas ..................................................................................... 28

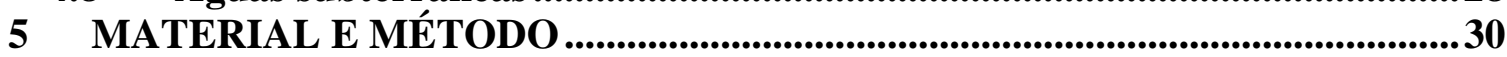

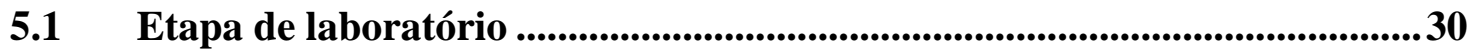

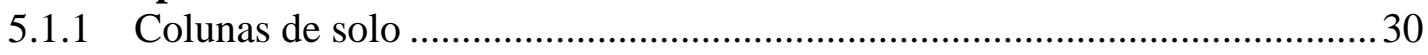

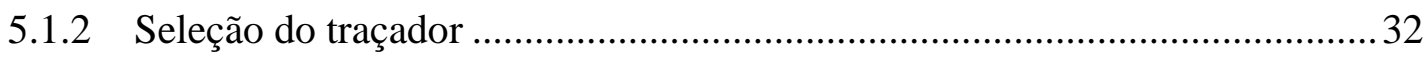

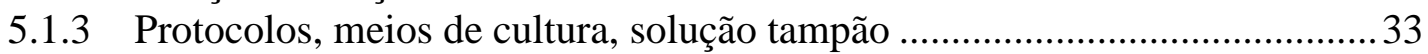

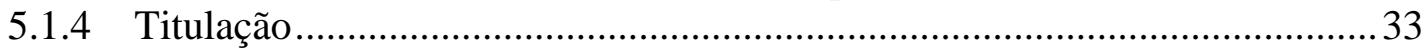

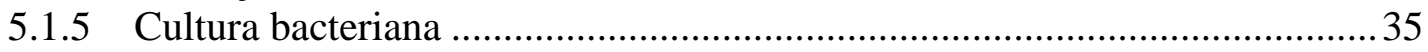

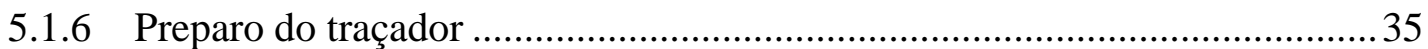

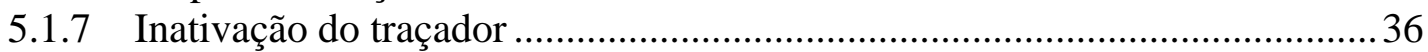

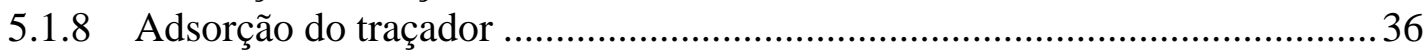

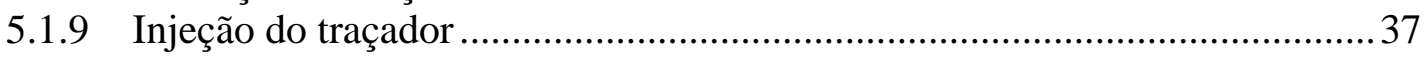

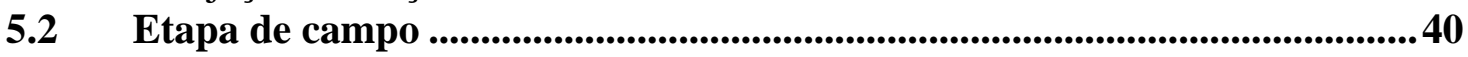

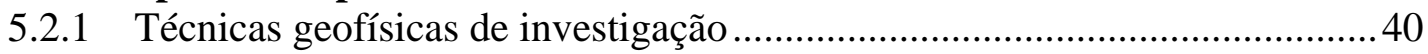

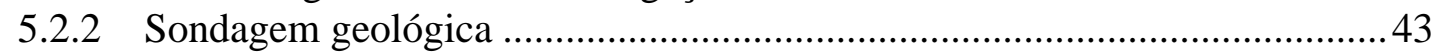

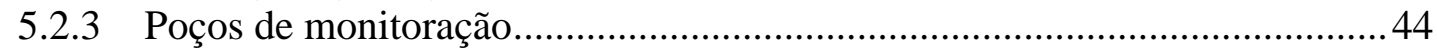

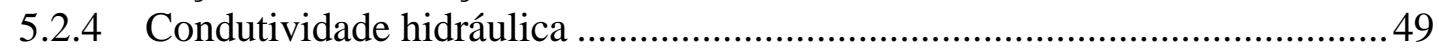

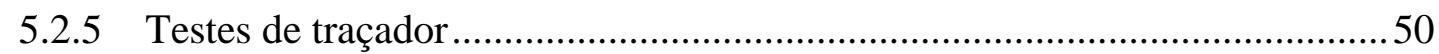

5.2.6 Amostragem de águas subterrâneas .........................................................51

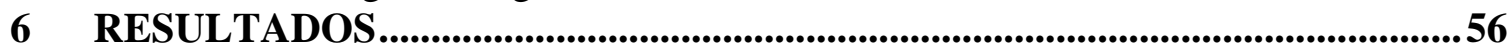

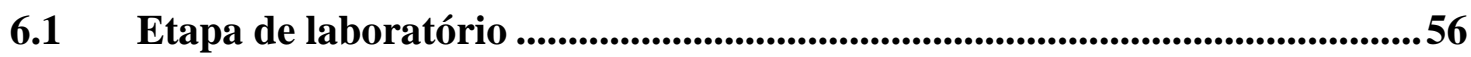




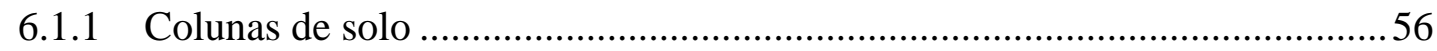

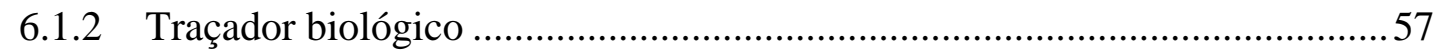

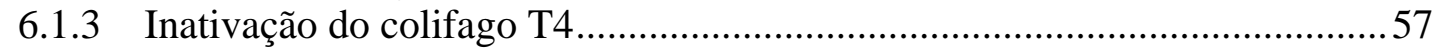

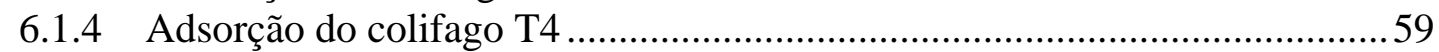

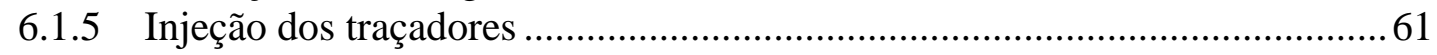

6.2 Etapa de campo ...............................................................................................................6 66

6.2.1 Sondagem elétrica e caminhamento eletromagnético ..................................66 66

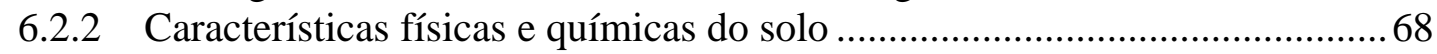

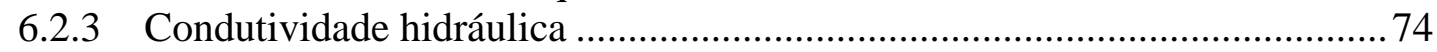

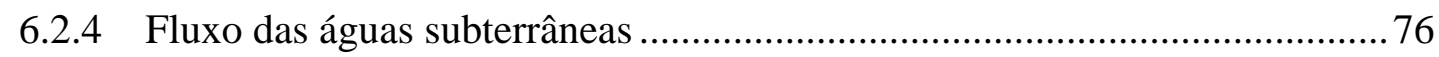

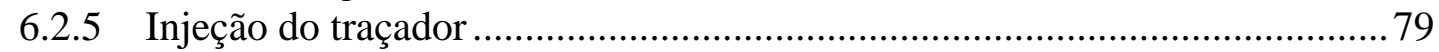

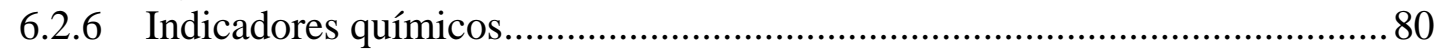

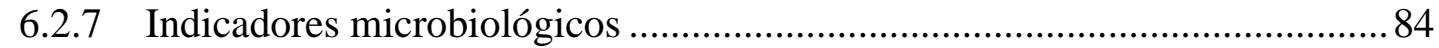

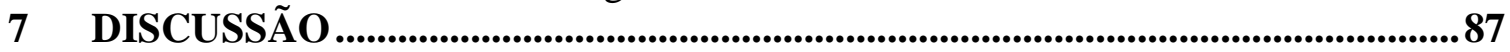

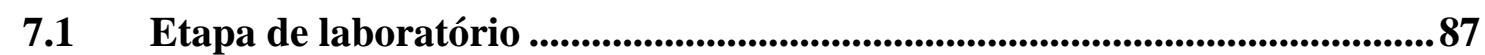

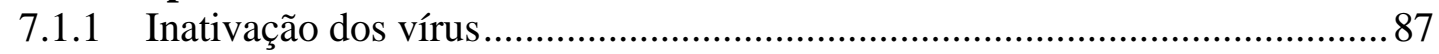

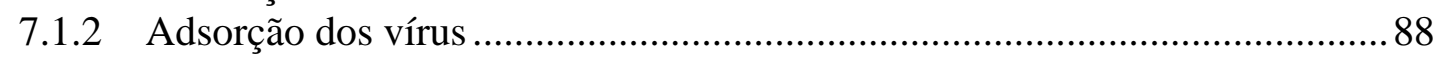

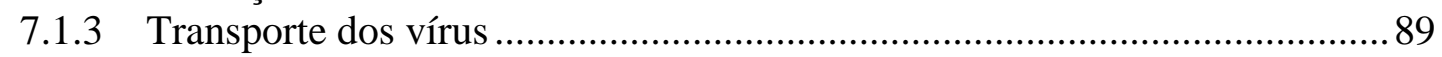

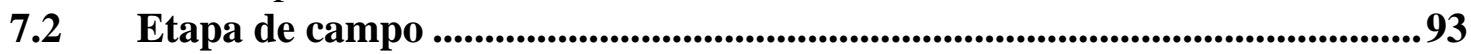

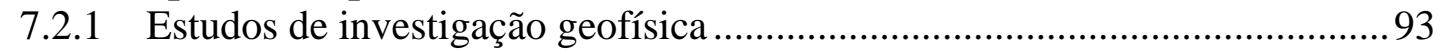

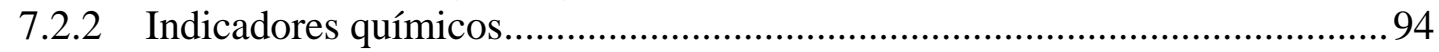

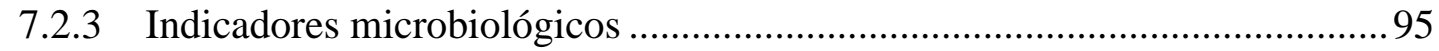

8 ASPECTOS LEGAIS........................................................................................99

8.1 Âmbito federal ..................................................................................................99

8.2 Âmbito estadual..................................................................................................99

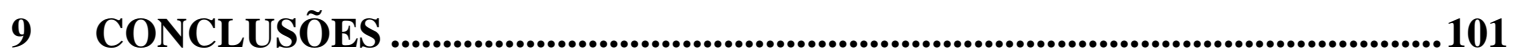

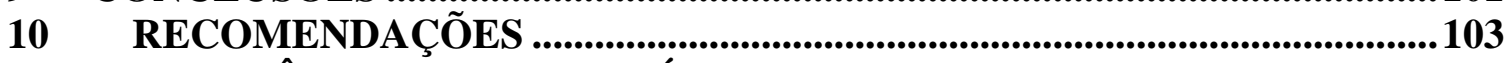

11 REFERÊNCIAS BIBLIOGRÁFICAS ........................................................ 104

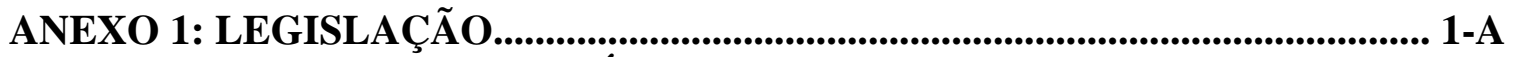

ANEXO 2: SONDAGENS ELÉTRICAS VERTICAIS E CAMINHAMENTOS

ELETROMAGNÉTICOS............................................................. 11-A

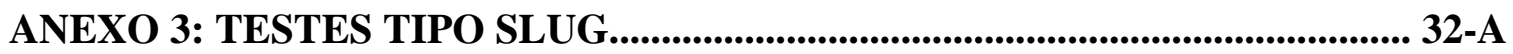




\section{LISTA DE FIGURAS}

Figura 3.1 Fotomicrografia do bacteriófago T4

Figura 4.1 Localização do cemitério de Vila Nova Cachoeirinha ............................................ 15

Figura 4.2 Aerofoto do cemitério de Vila Nova Cachoeirinha ................................................ 16

Figura 4.3 Principais causas de morte no município de São Paulo (1996-2000) .......................... 18

Figura 4.4 Extravasamento do necrochorume (março de 2000) ............................................ 20

Figura 4.5 Mapa geológico da área. .......................................................................................22

Figura 4.6 Descrição lito-estratigráfica do poço no Hospital Vila Nova Cachoeirinha................23

Figura 4.7 Altimetria do cemitério de Vila Nova Cachoeirinha ..................................................2 24

Figura 4.8 Precipitação mensal média (Posto Santana) ............................................................ 26

Figura 4.9 Bacia hidrográfica do rio Cabuçu de Baixo............................................................ 27

Figura 5.1 Esquema das colunas de solos .................................................................... 31

Figura 5.2 Esquema de titulação .................................................................................... 34

Figura 5.3 Placa de Petri com as unidades formadoras de placa do T4 ................................... 34

Figura 5.4 Esquema de injeção dos traçadores .................................................................... 37

Figura 5.5 Localização das sondagens elétricas, caminhamentos eletromagnéticos e sondagens

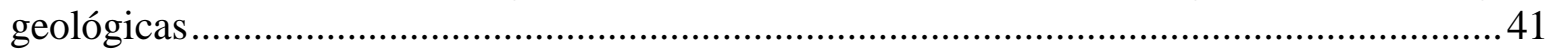

Figura 5.6 Mapa de localização dos poços de monitoração .................................................... 45

Figura 5.7 Mapa de detalhe dos poços de monitoração empregados no teste de traçador............46

Figura 5.8 Esquema construtivo dos poços de monitoração .................................................... 47

Figura 5.9 Poço de monitoração com os parâmetros do teste slug .............................................50

Figura 6.1 Concentração relativa $\left(C / C_{0}\right)$ do colifago $\mathrm{T} 4$ ao longo do tempo $(\mathrm{pH}=5,0) \ldots \ldots \ldots \ldots . . .58$

Figura 6.2 Concentração relativa $\left(C / C_{0}\right)$ do colifago $\mathrm{T} 4$ ao longo do tempo $(\mathrm{pH}=6,5) \ldots \ldots \ldots \ldots . . .59$

Figura 6.3 Quantidade adsorvida $\left(C^{*}\right)$ em função da concentração em equilíbrio $(C)$ do T4 ......60

Figura 6.4 Carga hidráulica calculada ao longo da coluna de solo arenoso.............................. 62

Figura 6.5 Relação entre valores de carga hidráulica $(\mathrm{m})$ calculados e observados .....................62

Figura 6.6 Concentração relativa $\left(C / C_{0}\right)$ do cloreto no efluente da coluna de solo arenoso.........63 63

Figura 6.7 Concentração relativa $\left(C / C_{0}\right)$ do T4 no efluente da coluna de solo arenoso ............... 64

Figura 6.8 Concentração relativa $\left(C / C_{0}\right)$ do cloreto no efluente da coluna de solo do cemitério.65

Figura 6.9 Concentração relativa $\left(C / C_{0}\right)$ do $\mathrm{T} 4$ no efluente da coluna de solo do cemitério.........65

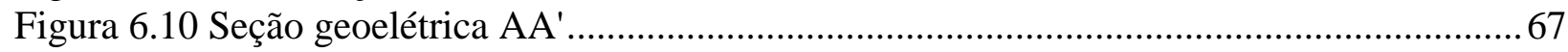

Figura 6.11 Condutividade elétrica aparente $(\mathrm{mS} / \mathrm{m})$ com campo indutor horizontal ...................69

Figura 6.12 Condutividade elétrica aparente $(\mathrm{mS} / \mathrm{m})$ com campo indutor vertical .................... 70

Figura 6.13 Perfil de alteração das rochas no cemitério ........................................................... 75

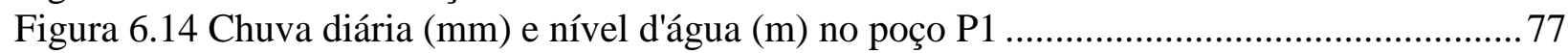

Figura 6.15 Mapa potenciométrico (março de 2000) ............................................................... 78

Figura 6.16 Concentração relativa $\left(C / C_{0}\right)$ observada e modelo ajustado no poço $\mathrm{P} 2$................. 79

Figura 6.17 Diagrama de Piper .................................................................................... 83

Figura 6.18 Resultados da reação em cadeia da polimerase (PCR) para pesquisa de adenovírus 86

Figura 7.1 Mapa de localização e data aproximada dos sepultamentos. 


\section{LISTA DE TABELAS}

Tabela 6.1 Características físico-químicas dos solos das colunas .............................................56

Tabela 6.2 Comprimento e condutividade hidráulica das colunas de solos...............................57

Tabela 6.3 Concentração $(C)$ do colifago T4 ao longo do tempo em dois pHs ...........................58

Tabela 6.4 Concentrações do colifago T4 no teste de adsorção nos solos..................................60

Tabela 6.5 Ajuste da isoterma de adsorção linear aos dados observados ..................................61

Tabela 6.6 Concentração observada do T4 no efluente da coluna de solo arenoso ..................... 63

Tabela 6.7 Parâmetros determinados na coluna de solo arenoso ..............................................64

Tabela 6.8 Parâmetros determinados na coluna de solo do cemitério ........................................65

Tabela 6.9 Resultados dos modelos geoelétricos de camadas ...................................................66

Tabela 6.10 Características físico-químicas das amostras de solos das sondagens geológicas .... 71

Tabela 6.11 Características físico-químicas das amostras de solos dos poços de monitoração.... 72

Tabela 6.12 Condutividade hidráulica $K$ determinada nos testes tipo slug ................................ 76

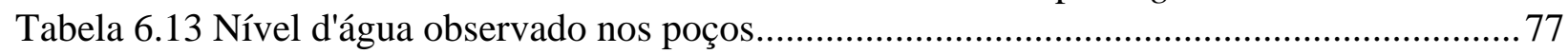

Tabela 6.14 Resultados dos indicadores químicos medidos in situ ....................................... 81

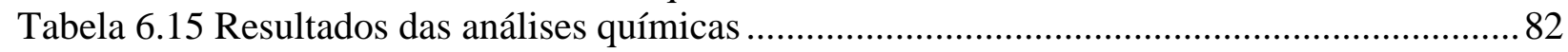

Tabela 6.16 Cátions e ânions maiores em \% de meq/L e classificação ..................................... 83

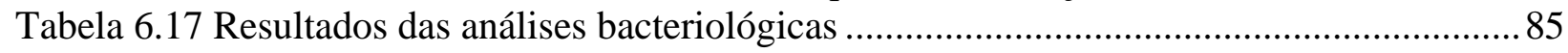

Tabela 6.18 Resultados das análises para pesquisa de vírus humano ....................................... 86 


\section{RESUMO}

Este trabalho avaliou a ocorrência e o transporte de microrganismos no aquífero freático do cemitério de Vila Nova Cachoeirinha, localizado em terrenos pré-cambrianos, zona norte do município de São Paulo.

A metodologia aplicada foi dividida em etapas de laboratório e de campo. No laboratório, foram montadas colunas de solo do cemitério. Traçadores químico e biológico foram injetados nas colunas e o seu fluxo monitorado no efluente. Um modelo numérico foi usado para simular o transporte dos traçadores nas colunas. Em campo, foram realizadas investigações a fim de caracterizar o aquífero freático. A monitoração da qualidade das águas foi realizada para estudar a ocorrência e o transporte de elementos químicos, bactérias e vírus nas águas subterrâneas.

No cemitério, o embasamento está a cerca de $9,0 \mathrm{~m}$ de profundidade na cota mais baixa e $20,5 \mathrm{~m}$ no topo. O nível freático encontra-se entre 4 e mais de $16 \mathrm{~m}$. O solo do cemitério é formado pelo material de alteração das rochas graníticas, de caráter predominantemente argiloso ( $43 \%$ de argila), $\mathrm{pH}=5,0$, matéria orgânica entre 0,7 e $4,2 \%$ e capacidade de troca de cátions entre 10,2 e 109,0 mmolc $/ \mathrm{kg}$. A condutividade hidráulica do aquífero varia de $2,90 \times 10^{-8}$ a 8,41 x $10^{-5} \mathrm{~m} / \mathrm{s}$. O gradiente hidráulico na porção oeste do cemitério é de aproximadamente $0,07 \mathrm{~m} / \mathrm{m}$; considerando o meio homogêneo e isotrópico e uma porosidade efetiva de $2 \%$, a velocidade linear média foi estimada em $8 \mathrm{~cm} /$ dia.

As amostras de água do aquífero freático do cemitério de Vila Nova Cachoeirinha apresentaram, principalmente, bactérias heterotróficas $\left(53 \times 10^{3} \mathrm{UFC} / \mathrm{mL}\right)$, bactérias proteolíticas (31 NMP/100 mL) e clostrídios sulfito-redutores (45 NMP/100 mL). Também foram encontrados enterovírus e adenovírus nas amostras. As principais fontes de contaminação das águas subterrâneas no cemitério são as sepulturas com menos de um ano, localizadas nas cotas mais baixas, próximas ao nível freático. Nestes locais, é maior a ocorrência de bactérias em geral. Há um grande consumo do oxigênio existente nas águas. As sepulturas ainda provocam um acréscimo na quantidade de sais minerais, aumentando a condutividade elétrica destas águas. Parece haver um aumento na concentração dos íons maiores bicarbonato, cloreto, sódio e cálcio, e dos metais ferro, alumínio, chumbo e zinco nas águas próximas de sepulturas.

As bactérias são transportadas poucos metros, diminuindo em concentração com o aumento da distância à fonte de contaminação. Os vírus parecem ter uma mobilidade maior que as bactérias, podendo atingir algumas dezenas de metros no aqüífero freático do cemitério de Vila Nova Cachoeirinha. Os vírus foram transportados, no mínimo, $3,2 \mathrm{~m}$ na zona não saturada até alcançar o aqüífero. 


\begin{abstract}
This work assessed occurrence and transport of microorganisms in the unconfined aquifer of Vila Nova Cachoeirinha cemetery, located on pre-cambrian terrains at the northern zone of the city of São Paulo

The applied methodology was divided in laboratory and field stages. In the lab, cemetery soil columns were designed; chemical and biological tracers were injected in the columns and the effluent was monitored. A numerical model was used to simulate the tracers' transport through the columns. In the field, several investigations were done to characterize the unconfined aquifer; water quality was monitored to study occurrence and transport of chemicals, bacteria and viruses in groundwater.

In Vila Nova Cachoeirinha cemetery, the depth to the bedrock is about $9.0 \mathrm{~m}$ at small elevation areas and $20.5 \mathrm{~m}$ at the top of the hill. The depth to the water table varies from 4 to over $16 \mathrm{~m}$. The soil is formed by the weathered material of the granite rocks, clay content of $43 \%, \mathrm{pH}=5,0$, cation exchange capacity between 10.2 and $109.0 \mathrm{mmolc} / \mathrm{kg}$. The hydraulic conductivity of the aquifer varies from $2.90 \times 10^{-8}$ to $8.41 \times 10^{-5} \mathrm{~m} / \mathrm{s}$. The hydraulic gradient at the western part of the study area is about $0.07 \mathrm{~m} / \mathrm{m}$; considering a homogeneous and isotropic medium and an effective porosity of $2 \%$, the average linear velocity was estimated in $8 \mathrm{~cm} /$ day.

The water samples of the unconfined aquifer of Vila Nova Cachoeirinha cemetery presented, mainly, heterotrophic bacteria $\left(53 \times 10^{3} \mathrm{UFC} / \mathrm{mL}\right)$, proteolitic bacteria $(31 \mathrm{NMP} / 100$ $\mathrm{mL}$ ) and clostridium perfringes (45 NMP/100 $\mathrm{mL})$. We have also found enterovirus and adenovirus in groundwater. The main sources of contamination are the within-a-year-graves located at the low elevation areas, close to the water table. At these sites, the occurrence of bacteria is greater and there is a greater consumption of oxygen in the water due to oxidation of organic matter. Moreover, the graves cause an increase in salts and electrical conductivity of the groundwater. There seems to be an increase in major ions: hydrogen carbonate, chloride, sodium, calcium; and metals: iron, aluminium, lead and zinc, next to the graves.

The bacteria traveled a distance of a few meters, decreasing in concentration with increasing distance to the graves. The viruses seem to be more mobile than bacteria, they traveled distances of tens of meters at the Vila Nova Cachoeirinha cemetery. The viruses were transported at least $3.2 \mathrm{~m}$ through the unsaturated zone before reaching the unconfined aquifer.
\end{abstract}




\section{INTRODUÇÃO}

A palavra cemitério do grego koimetérion, "dormitório", do latim coemeteriu, designava, a princípio, o lugar onde se dorme, quarto, dormitório. Sob a influência do cristianismo, o termo tomou o sentido de campo de descanso após a morte. O cemitério também é conhecido como necrópole, carneiro, sepulcrário, campo-santo e vários eufemismos, como "cidade dos pésjuntos" e "última morada".

Aquela palavra teve uma evolução semântica ao longo do tempo, impondo-se definitivamente na língua francesa, desde o século XVI. Em inglês, o emprego da palavra cemetery na linguagem corrente parece mais tardio. Churchyard ou graveyard só foram substituídas por cemetery no século XIX e para designar, por oposição, uma outra forma de cemitério, o rural cemetery (ARIÈS, 1977). Segundo BAYARD (1993), na terminologia hebraica, o cemitério é designado por termos bastante surpreendentes: Berth Olam (casa da eternidade) e Beth ha' hayim (casa da vida).

Os cemitérios de cadáveres humanos são monumentos à memória daqueles que morreram e que os vivos fazem questão de perpetuar. Conseqüentemente, ao longo do tempo, este tipo de construção adquiriu a condição de inviolabilidade no que tange à pesquisa científica nos seus diferentes aspectos. Entretanto, sociólogos, antropólogos, folcloristas e outros têm dado excelentes contribuições para um melhor conhecimento dos hábitos, costumes e práticas funerárias.

Se houve uma consolidação científica da pesquisa sobre a temática da morte, outro tanto não se poderá dizer sobre a questão "cemitérios e meio ambiente". Os cemitérios nunca foram incluídos nas listas de fontes tradicionais de contaminação ambiental, nunca foram objeto de um estudo deste tipo, apesar da existência de alguns relatos históricos (MULDER, 1954 apud BOUWER, 1978; SCHRAPS, 1972 apud PACHECO, 2000; RAGON, 1981 apud PACHECO, 2000) sobre contaminação das águas subterrâneas e poços de abastecimento público. A questão sobre cemitérios precisa ser conhecida em todos os seus aspectos, principalmente, quando o cadáver humano possa ser causa de alterações ambientais e pôr em risco a saúde dos vivos.

Depois de morto, o corpo humana se transforma. Passa a ser um ecossistema de 
populações formado por artrópodes, bactérias, microrganismos patogênicos e destruidores de matéria orgânica e outros, podendo pôr em risco o meio ambiente e a saúde pública. Sendo os cemitérios repositórios de cadáveres e laboratórios de decomposição, apresentam riscos que exigem cuidados técnicos e científicos na sua implantação e operação.

Conseqüentemente, investigações estão sendo desenvolvidas no Centro de Pesquisas de Águas Subterrâneas do Instituto de Geociências da Universidade de São Paulo (USP), sob a coordenação do Professor Alberto Pacheco, e em outras instituições de pesquisa no Brasil e no exterior, visando o conhecimento das relações do corpo morto, no seu processo de desintegração, com o meio ambiente - solo e águas subterrâneas. Os trabalhos sobre o tema têm o apoio indispensável do Laboratório de Microbiologia Ambiental do Instituto de Ciências Biomédicas da USP. Inicialmente, orientados pela Profa. Therezinha Martins, e posteriormente, pela equipe da Profa. Vívian Pellizari.

Dentro da linha de pesquisa "cemitérios e meio ambiente", foi desenvolvido o nosso projeto, que procurou avaliar a ocorrência e o transporte de microrganismos no cemitério de Vila Nova Cachoeirinha, localizado na zona norte do município de São Paulo, escolhido devido à sua situação topográfica, aos problemas de operação relacionados com sepultamentos por inumação no solo e grande adensamento populacional no em torno.

Os estudos foram desenvolvidos no aqüífero freático, de porosidade primária granular. A eventual ocorrência de fraturas e falhas não foi considerada. A metodologia aplicada foi dividida em duas etapas: de laboratório e de campo. No laboratório, o transporte de vírus no aquíffero foi simulado, montando colunas de solo do cemitério, alimentadas por uma vazão constante de água destilada. Traçadores químico (cloreto) e biológico (colifago T4) foram injetados nas colunas e o seu fluxo monitorado no efluente. Um modelo numérico foi ajustado aos dados observados para estimar a dispersividade e adsorção dos vírus no meio. Em campo, foram realizadas investigações geofísicas, sondagens geológicas, coleta de amostras de solo e testes para determinação da condutividade hidráulica do meio, a fim de caracterizar o aquífero freático. A monitoração da qualidade das águas foi realizada para estudar a ocorrência e o transporte de elementos químicos, bactérias e vírus nas águas subterrâneas. 


\section{OBJETIVOS}

O objetivo desta pesquisa foi avaliar a ocorrência e o transporte de microrganismos no aquífero freático do cemitério de Vila Nova Cachoeirinha, situado na zona norte do município de São Paulo.

Também foi estudado o transporte de vírus no aqüífero freático do cemitério, através da simulação em colunas de solo no laboratório. 


\section{REVISÃO BIBLIOGRÁFICA}

\subsection{Cemitérios e meio ambiente}

Os estudos sobre cemitérios e meio ambiente são incipientes. A WORLD HEALTH ORGANIZATION - WHO (1998) se mostrou preocupada com o impacto que os cemitérios poderiam causar ao meio ambiente, através do aumento da concentração de substâncias orgânicas e inorgânicas nas águas subterrâneas e a eventual presença de microrganismos patogênicos, e enfatizou a necessidade de mais pesquisa a respeito do assunto. PACHECO (2000) fez uma sistematização crítica das pesquisas sobre cemitérios e meio ambiente realizadas até 2000, indicando a carência de trabalhos correlatos sobre o tema.

BERGAMO (1954) defendeu a necessidade de estudos geológicos e sanitários das áreas de cemitérios e a verificação das possibilidades de contaminação das águas subterrâneas e superficiais. PACHECO (1986) alertou para a necessidade de implantação cuidadosa de cemitérios e fixação de faixas de proteção sanitária como forma de garantir a preservação das águas subterrâneas e o uso potável das mesmas.

Parece que a pesquisa de maior impacto no Brasil, e no mundo, sobre contaminação de águas subterrâneas por cemitérios é a de PACHECO et al. (1991) que estudaram três cemitérios dos municípios de São Paulo e de Santos e constataram a contaminação do aquífero freático por microrganismos - coliformes totais, coliformes fecais, estreptococos fecais, clostrídios sulfitoredutores e outros - oriundos da decomposição dos corpos sepultados por inumação no solo.

MENDES et al. (1989) foram os primeiros a aplicar técnicas geofísicas para estudar a contaminação em cemitérios, correlacionando anomalias de condutividade elétrica aparente, em estudos eletromagnéticos, com a contaminação oriunda dos sepultamentos. MIOTTO (1990) propôs uma metodologia baseada em mapeamentos de informações geológicas, geotécnicas e hidrológicas, visando a adequabilidade de solos para áreas destinadas à implantação de cemitérios. MIGLIORINI (1994) observou o aumento na concentração de íons e de produtos nitrogenados nas águas subterrâneas do Cemitério de Vila Formosa em São Paulo. DENT (1995) apud WHO (1998) constatou o aumento da condutividade elétrica e sais minerais nas águas subterrâneas próximas de sepultamentos recentes no cemitério Botany na Austrália. 
CARVALHO JUNIOR \& COSTA E SILVA (1997) aplicaram potencial espontâneo e eletrorresistividade no estudo do cemitério do Bengui, em Belém do Pará, comprovando o fluxo de águas subterrâneas, do cemitério em direção a uma área residencial. PEQUENO MARINHO (1998) constatou a presença de bactérias e produtos nitrogenados no aqüífero freático do Cemitério São João Batista em Fortaleza. BRAZ et al. (2000) encontraram números elevados de coliformes totais e fecais em poços a jusante do cemitério do Bengui em Belém.

\subsection{Composicão do necrochorume}

A composição do corpo de um homem adulto de $70 \mathrm{~kg}$ é mostrada no Quadro 3.1; a da mulher situa-se entre um quarto e dois terços da do homem (DENT \& KNIGHT apud WHO (1998).

Quadro 3.1 Composição aproximada do corpo de um homem adulto de $70 \mathrm{~kg}$

\begin{tabular}{|lr|}
\hline Substância & Quantidade \\
\hline Carbono & $16.000 \mathrm{~g}$ \\
Nitrogênio & $1.800 \mathrm{~g}$ \\
Cálcio & $1.100 \mathrm{~g}$ \\
Fósforo & $500 \mathrm{~g}$ \\
Enxofre & $140 \mathrm{~g}$ \\
Potássio & $140 \mathrm{~g}$ \\
Sódio & $100 \mathrm{~g}$ \\
Cloreto & $95 \mathrm{~g}$ \\
Magnésio & $19 \mathrm{~g}$ \\
Ferro & $4,2 \mathrm{~g}$ \\
Água & $70-74 \%$ \\
\hline
\end{tabular}

Fonte: DENT \& KNIGHT (1998) apud WHO (1998)

Após a morte, o corpo humano sofre putrefação, que é a destruição dos tecidos do corpo por ação das bactérias e enzimas, resultando na dissolução gradual dos tecidos em gases, líquidos e sais. Os gases produzidos são $\mathrm{H}_{2} \mathrm{~S}, \mathrm{CH}_{4}, \mathrm{CO}_{2}, \mathrm{NH}_{3}$ e $\mathrm{H}_{2}$. O odor é causado por alguns destes gases e por pequena quantidade de mercaptan (POUNDER, 1995) - substância que contém sulfeto de hidrogênio ligado a carbono saturado.

Dependendo das condições ambientais, a putrefação pode ser observada 24 horas após a morte, com a formação dos gases em dois ou três dias. A decomposição do corpo pode durar 
alguns meses até vários anos, dependendo da ação ambiental. Em clima tropical, o cadáver demora aproximadamente três anos para ser decomposto; em clima temperado, a decomposição pode durar dez anos (POUNDER, 1995). Com o rompimento dos tecidos, ocorre a liberação dos gases, líquidos e sais para o meio ambiente.

A contaminação pode atingir o aqüífero através do necrochorume - neologismo que designa o líquido liberado intermitentemente pelos cadáveres em putrefação, que também pode conter microrganismos patogênicos - transportado pelas chuvas infiltradas nas covas ou pelo contato dos corpos com a água subterrânea. Trata-se de uma solução aquosa rica em sais minerais e substâncias orgânicas degradáveis, de cor castanho-acinzentada, viscosa, polimerizável, de cheiro forte e com grau variado de patogenicidade. SILVA (1998) afirma que o necrochorume é constituído por $60 \%$ de água, $30 \%$ de sais minerais e $10 \%$ de substâncias orgânicas. Segundo SMITH et al. (1983) apud MIGLIORINI (1994), a decomposição destas substâncias orgânicas pode produzir diaminas, como a cadaverina $\left(\mathrm{C}_{5} \mathrm{H}_{14} \mathrm{~N}_{2}\right)$ e a putrescina $\left(\mathrm{C}_{4} \mathrm{H}_{12} \mathrm{~N}_{2}\right)$, que podem ser degradadas, gerando amônio $\left(\mathrm{NH}_{4}{ }^{+}\right)$. De acordo com WILHELM et al. (1994), o amônio pode ser gerado, em condições anaeróbias, pela hidrólise das moléculas orgânicas, ou seja:

$$
\begin{aligned}
& \text { Proteínas }+\mathrm{H}_{2} \mathrm{O} \rightarrow \text { aminoácidos (carboxila }+ \text { amina) } \\
& \text { Aminoácidos (carboxila }+ \text { amina) } \rightarrow \mathrm{NH}_{4}{ }^{+}+\text {compostos orgânicos }
\end{aligned}
$$

Para MADIGAN et al. (1997), um grupo de clostrídios obtém sua energia através da fermentação de aminoácidos. Os produtos da fermentação podem ser: ácido isobutírico, sulfeto de hidrogênio, metilmercaptan, cadaverina e putrescina. Esses clostrídios são capazes de fermentar a putrescina da seguinte forma (MADIGAN et al., op. cit.):

$$
10 \mathrm{C}_{4} \mathrm{H}_{12} \mathrm{~N}_{2}^{+}+26 \mathrm{H}_{2} \mathrm{O} \rightarrow \text { 6acetato }^{-}+7 \text { butirato }^{-}+20 \mathrm{NH}_{4}^{+}+16 \mathrm{H}_{2}+13 \mathrm{H}^{+}
$$

Consumindo oxigênio, a matéria orgânica é oxidada: $\mathrm{CH}_{2} \mathrm{O}+\mathrm{O}_{2} \rightarrow \mathrm{CO}_{2}+\mathrm{H}_{2} \mathrm{O}$, e o amônio é transformado em nitrato (WILHELM et al., op. cit.):

$$
\mathrm{NH}_{4}{ }^{+}+2 \mathrm{O}_{2} \rightarrow \mathrm{NO}_{3}^{-}+2 \mathrm{H}^{+}+\mathrm{H}_{2} \mathrm{O}
$$


Não sabemos muito sobre a composição do necrochorume em relação à carga microbiológica. Devido a sua composição química, é provável que encontremos números elevados de bactérias degradadoras de matéria orgânica (bactérias heterotróficas), de proteínas (bactérias proteolíticas) e lipídios (bactérias lipolíticas). Devemos encontrar bactérias que são normalmente excretadas por humanos (e animais), como Escherichia coli, Enterobacter, Klebsiella e Citrobacter (as quatro formam o grupo coliforme total), Streptococcus faecalis; alguns clostrídios como Clostridium perfringes e Clostridium welchii, entre outros. É provável que estejam presentes bactérias patogênicas, como Salmonella typhi, e vírus humanos, como enterovírus. Biólogos são de opinião que o perigo do necrochorume está na sua patogenicidade (OTTMAN, 1987).

\subsection{Fenômenos transformativos}

Os corpos sepultados em cemitérios, normalmente, estão sujeitos aos fenômenos transformativos destrutivos. Porém, sob certas condições ambientais, podem ocorrer fenômenos transformativos conservadores, como a mumificação e a saponificação (PACHECO \& BATELLO, 2000).

A mumificação é a dessecação ou desidratação dos tecidos. Aparece em condições de clima quente, seco, com correntes de ar. Existem determinados tipos de solos que propiciam a mumificação, como os arenosos das regiões desérticas. Em solos calcários, os corpos inumados podem sofrer uma fossilização incipiente, graças à substituição catiônica de sódio e potássio pelo cálcio. Assim, têm sido encontradas múmias naturais, muito bem conservadas, sem ataúdes, depositadas no solo, em cavernas ou catacumbas (PACHECO \& MATOS, 2000).

A saponificação é a hidrólise da gordura com liberação de ácidos graxos, os quais, pela acidez, inibem as bactérias putrefativas, atrasando a decomposição do cadáver. A adipocera é resultante da saponificação. É a massa branca, mole, de aspecto céreo, que se forma nos diversos tecidos e órgãos do cadáver. Segundo POUNDER (1995), um ambiente quente, úmido e anaeróbio, assim como a presença de bactérias endógenas, favorece a saponificação. $\mathrm{O}$ solo argiloso, pouco permeável, quando saturado de água facilita esse tipo de fenômeno. Cabe dizer, que os solos com elevada percentagem de argila não são recomendáveis para a instalação de cemitérios. 
Na cidade de São Paulo, com uma população aproximada de 10 milhões de habitantes e 36 cemitérios, a escassez de espaços para a construção de novos cemitérios levou os serviços funerários da Prefeitura a adotarem a prática de reuso das sepulturas. Conforme o Artigo 551 (Anexo 1) do Código Sanitário Estadual (SÃO PAULO, 1991), após um período mínimo de três anos para adultos e dois para crianças, os restos mortais são retirados da sepultura, possibilitando a reutilização daquele espaço. A saponificação dos cadáveres se constitui num problema sério para a referida prática, por retardar a reutilização das sepulturas (PACHECO \& MATOS, 2000).

\subsection{Agentes causadores de doenças de veiculação hídrica}

Em cemitérios, as águas subterrâneas podem ser contaminadas por microrganismos existentes nos corpos em decomposição. Se essa água for captada por poços, quem fizer uso da mesma, corre, eventualmente, riscos de saúde, pois este recurso pode veicular doenças como a febre tifóide, paratifóide, cólera e outras.

Em geral, as doenças de veiculação hídrica causam fortes distúrbios gastrintestinais, tais como vômitos, cólicas e diarréias. As mais comuns no Brasil são a hepatite, a leptospirose, a febre tifóide e a cólera. No Quadro 3.2 são apresentados alguns tipos de protozoários, bactérias e vírus encontrados nas águas; o tamanho médio destes organismos; algumas características e as doenças que podem provocar no homem.

As bactérias são microrganismos procariontes. Algumas têm papéis importantes na natureza, como nos processos de decomposição da matéria orgânica, fermentação e fixação do nitrogênio, enquanto outras são prejudiciais à saúde humana. Os seres procariontes são caracterizados por uma estrutura celular simples desprovidos de membrana nuclear. O envoltório celular destes organismos é formado pela membrana citoplasmática e pela parede celular. A membrana citoplasmática é uma estrutura altamente especializada, constituída de lipídeos e proteínas. Algumas proteínas presentes na membrana são responsáveis pelo transporte de elétrons, importante na retenção dos microrganismos ao solo por adsorção.

Menores que as bactérias, os vírus são obrigatoriamente parasitas, isto é, eles não possuem a capacidade de viver e reproduzir sem a presença de uma célula hospedeira que forneça energia. São constituídos de uma molécula de ácido nucléico (DNA ou RNA), circundado por uma capa protéica. Os vírus infectam animais, plantas e bactérias. Mais de cem tipos diferentes de vírus podem ser excretados em fezes humanas. Podendo-se encontrar mais de 
um milhão de partículas viróticas por gramas de fezes de pessoa infectada, manifestando ou não a doença. Já foram encontradas concentrações de $1 \times 10^{5}$ partículas virais infecciosas por litro de esgotos (ORGANIZACIÓN MUNDIAL DE LA SALUD - OMS, 1979).

Quadro 3.2 Patógenos humanos comuns em águas

\begin{tabular}{|c|c|c|}
\hline Tipo & Tamanho & Características e efeitos \\
\hline Protozoários & $(\mu \mathrm{m})$ & \\
\hline Cryptosporidium & $4-6$ & Resistente à cloração. Provoca gastrenterite. \\
\hline Entamoeba histolytica & $20-40$ & $\begin{array}{l}\text { Locomove-se e alimenta-se por meio de pseudópodes. } \\
\text { Causa amebíase. }\end{array}$ \\
\hline Giardia lamblia & $6-12$ & Apresenta simetria bilateral. Causa gastrenterite. \\
\hline Bactérias & $(\mu \mathrm{m})$ & \\
\hline Escherichia coli & $\begin{array}{c}1,1-1,5 \mathrm{x} \\
2,0-6,0\end{array}$ & $\begin{array}{l}\text { Bacilo reto, gram-negativo, anaeróbio facultativo, pode } \\
\text { provocar diarréia, dores abdominais. }\end{array}$ \\
\hline Legionella pneumophila & $\begin{array}{l}0,3-0,9 x \\
2,0-20\end{array}$ & $\begin{array}{l}\text { Bacilo, gram-negativo, aeróbio, pode provocar } \\
\text { pneumonia e febre. }\end{array}$ \\
\hline Leptospira interrogans & $\begin{array}{c}0,1 \times \\
6,0-12\end{array}$ & $\begin{array}{l}\text { Célula em forma de hélice flexível, gram-negativo, } \\
\text { aeróbio, causa leptospirose. }\end{array}$ \\
\hline Salmonella typhi & $\begin{array}{c}0,7-1,5 \mathrm{x} \\
2,0-5,0\end{array}$ & $\begin{array}{l}\text { Gram-negativo, anaeróbio facultativo, causa febre } \\
\text { tifóide. }\end{array}$ \\
\hline $\begin{array}{l}\text { Shigella dysenteriae, } \\
\text { S. flexneri, S. sonnei }\end{array}$ & $\begin{array}{c}0,7-1,5 \mathrm{x} \\
2,0-5,0\end{array}$ & $\begin{array}{l}\text { Bacilo reto, anaeróbio facultativo, gram-negativo, } \\
\text { causa febre intestinal, gastrenterite, disenteria. }\end{array}$ \\
\hline Vibrio cholerae & $\begin{array}{c}0,5-0,8 \times \\
1,4-2,6 \\
\end{array}$ & $\begin{array}{l}\text { Bacilo reto ou curvo, gram-negativo, anaeróbio } \\
\text { facultativo, causa cólera. }\end{array}$ \\
\hline Vírus & $(n \mathrm{~m})$ & \\
\hline Adenovírus & 100 & Resistente no ambiente. Provoca infecções respiratórias \\
\hline Agente Norwalk & $30-38$ & $\begin{array}{l}\text { Icosaedro, inativação ocorre em } \mathrm{pH} \text { entre três e cinco, } \\
\text { pode causar gastrenterite, vômito, diarréia. }\end{array}$ \\
\hline $\begin{array}{l}\text { Coxsackie humano } \\
\text { A1 a A22, A24, B1 a B6 }\end{array}$ & $22-30$ & $\begin{array}{l}\text { Família Picornaviridae: Icosaedro, algumas espécies } \\
\text { são instáveis em pH abaixo de sete. Podem provocar } \\
\text { doenças respiratórias, meningite, miocardite. }\end{array}$ \\
\hline $\begin{array}{l}\text { Echo humano } \\
1 \text { a } 27,11 \text { a } 27,29 \text { a } 33\end{array}$ & $22-30$ & $\begin{array}{l}\text { Doenças associadas: meningite, doenças respiratórias, } \\
\text { erupções cutâneas, diarréia, febre. }\end{array}$ \\
\hline Hepatite A & $22-30$ & $\begin{array}{l}\text { Muito estável, resistente em meio ácido e em elevada } \\
\text { temperatura. Provoca hepatite e gastrenterite. }\end{array}$ \\
\hline Poliovírus humano 1, 2, 3 & $22-30$ & Doenças associadas: paralisia, meningite, febre. \\
\hline Reovírus $1,2,3$ & $60-80$ & $\begin{array}{l}\text { Icosaedro, mas muitos apresentam a forma esférica. } \\
\text { Relativamente estáveis. Doenças: infecções do trato } \\
\text { respiratório superior, enterite em crianças e bebês. }\end{array}$ \\
\hline Rotavírus grupo B & 70 & $\begin{array}{l}\text { Icosaedro, estável até o pH } 3,0 \text { e relativamente } \\
\text { resistente ao calor. Provoca gastrenterite. }\end{array}$ \\
\hline
\end{tabular}

Adaptado de OMS (1979); KESWICK (1984); INTERNATIONAL COMMITTEE OF TAXONOMY OF VIRUS - ICTV (1995); MADIGAN et al. (1997). 


\subsection{Sobrevivência de microrganismos}

A sobrevivência e o transporte dos microrganismos na subsuperfície dependem de três fatores básicos: clima, tipo de solo e natureza dos microrganismos. Os parâmetros que influem são muitos: temperatura, precipitação, teor de umidade do solo, atividade microbiana, pH, quantidade de matéria orgânica presente, textura do solo, e outros (GERBA \& BITTON, 1984).

Alguns autores (GERBA et al., 1975; GERBA \& BITTON, op. cit.; YATES \& YATES, 1988) resumem os estudos sobre a influência dos fatores citados na sobrevivência e transporte dos microrganismos. Em geral, as bactérias sobrevivem por mais tempo em temperaturas mais baixas, em solos mais úmidos, com menor atividade microbiana, em ambiente mais alcalino e com maior quantidade de matéria orgânica. Os vírus também são mais persistentes em temperaturas mais baixas; alguns sofrem inativação na presença de atividade microbiana, mas outros são protegidos pela adsorção, podendo sobreviver por mais tempo. A presença de matéria orgânica e de cátions também pode prolongar a sobrevivência por adsorção, em alguns casos. Os vírus são mais persistentes em ambiente mais úmido e em $\mathrm{pH}$ próximo a neutro. Portanto, solos com alto teor de umidade e levemente alcalinos são os mais favoráveis para a sobrevivência dos microrganismos.

O tempo de sobrevivência de bactérias e vírus varia muito, em geral, é de dois a três meses, apesar de terem sido observados períodos de sobrevivência de até cinco anos em condições ideais (ROMERO, 1970).

\subsection{Transporte de microrganismos}

Os microrganismos, ao serem transportados na subsuperfície, estão sujeitos a diversos processos que podem removê-los das águas subterrâneas. Eles podem ser sorvidos na superfície de minerais do aqüífero ou por moléculas orgânicas presentes no meio, podendo também interagir quimicamente com o meio. Em resposta a estes processos, os microrganismos serão transportados em velocidades menores do que as das águas subterrâneas. Este efeito é chamado retardamento (MCDOWELL-BOYER et al., 1986).

A remoção dos microrganismos é inversamente proporcional ao tamanho dos grãos do solo. A maior remoção acontece no manto superficial que se forma nos primeiros dois a seis 
milímetros de solo. Com o tempo, alguns microrganismos poderão ficar presos entre os grãos a maiores profundidades, passando a agir como filtros. Esta acumulação de microrganismos na superfície aumenta o poder de filtragem do meio. É claro que esse mecanismo de retenção tem sua maior importância para organismos maiores como as bactérias. Para os vírus que são bem menores, o mecanismo de adsorção é mais importante (MCDOWELL-BOYER et al., 1986).

Os primeiros estudos sobre o transporte de microrganismos em meios porosos são do início do século XX. DITTHORN \& LUERSSEN (1909) apud ROMERO (1970) injetaram uma solução de água com bactérias em um aqüífero de litologia de areia e cascalho e observaram que o tempo de transporte para atingir um poço de observação, à distância de $18 \mathrm{~m}$ do poço injetor, foi de nove dias.

Naquela época, era comum a utilização de latrinas para a disposição de excrementos humanos. Aquelas eram deliberadamente construídas para atingirem o aqüífero freático, com o propósito de obter a decomposição do material fecal (CALDWELL \& PARR, 1937). Alguns autores (CALDWELL \& PARR, op. cit.; CALDWELL, 1938; CALDWELL \& PARR, 1938) examinaram como os contaminantes eram transportados desde as latrinas até poços de observação instalados em torno das mesmas. As principais conclusões daqueles trabalhos podem ser resumidas da seguinte forma: o contaminante segue a direção preferencial do fluxo das águas subterrâneas (CALDWELL \& PARR, 1937; CALDWELL, op. cit.); o mecanismo mais importante de transporte é a advecção (CALDWELL \& PARR, 1938); a contaminação química consegue atingir distâncias maiores que a biológica que sofre filtragem no meio (CALDWELL \& PARR, 1937). Os trabalhos mencionados apontaram o perigo de contaminação devido à proximidade entre o nível freático e a superfície, e distâncias mínimas recomendadas entre fontes de contaminação e de abastecimento. Ou seja, naqueles tempos já eram discutidos os problemas comuns da hidrogeologia moderna, como a vulnerabilidade e proteção de aqüíferos.

Os conhecimentos foram se ampliando, em virtude dos estudos de viabilidade para a injeção de efluentes de esgotos domésticos e industriais em solos (BAARS, 1957; KRONE et al., 1957; WESNER \& BAIER, 1970; BOUWER et al., 1974a; BOUWER et al., 1974b; GOLDSHMID, 1974). Acreditava-se que a injeção do contaminante no solo poderia ser uma maneira adequada de eliminar o esgoto, repor as reservas do aqüífero e aumentar a produtividade agrícola. Atualmente, fala-se novamente em reciclagem e reuso das águas, mas recomenda-se estudos detalhados da área em questão e maiores cuidados na utilização do sistema de injeção de efluentes em solos, pois em alguns casos, foram observadas as presenças de vírus e bactérias a 
grandes distâncias do poço injetor (FLETCHER \& MEYERS, 1974; SINTON, 1979 apud KESWICK et al., 1982).

Os estudos sobre o transporte de vírus em solos são mais recentes e menos abundantes do que os de bactérias, devido principalmente às dificuldades na análise e detecção de organismos tão pequenos $(20-80 \mathrm{~nm})$. Um dos trabalhos mais relevantes foi desenvolvido por DREWRY \& ELIASSEN (1968) que utilizaram colunas de solos com nove composições de areia, silte e argila para entender os mecanismos de movimento de vírus através dos solos. Três bacteriófagos foram marcados com um traçador radioativo e introduzidos em colunas de solos saturadas; um fluxo contínuo foi mantido, e as concentrações dos vírus foram observadas para diversas alturas das colunas. Aqueles autores notaram que o processo de adsorção dos vírus nas paredes do solo pode ser representado pela isoterma de adsorção linear. Ou seja, a concentração de partículas adsorvidas cresce linearmente com a concentração de partículas em solução. Apesar de autores modernos (GRANT et al., 1993) proporem outros modelos mais complexos para representar a adsorção de vírus nos solos, a isoterma de adsorção linear ainda é bastante utilizada pela sua simplicidade.

Os vírus possuem cargas negativas para a maioria dos $\mathrm{pHs}$ encontrados nos solos. Minerais e vírus possuem cargas negativas para pHs acima de sete e tendem a repelir uns aos outros. Esta eletronegatividade é reduzida com a diminuição do $\mathrm{pH}$, permitindo uma maior aderência entre as partículas e o meio. Os vírus possuem cargas positivas em pHs abaixo do seu ponto isoelétrico, podendo ser adsorvidos por superfícies de carga negativa como minerais de argila e matéria orgânica coloidal. Acima do ponto isoelétrico, os vírus têm carga negativa e podem ser imobilizados via adsorção aniônica (SCHAUB \& SORBER, 1976).

A imobilização também aumenta com o aumento da concentração de sais e cátions bi ou trivalentes. A concentração destes cátions tende a comprimir a espessura da camada de cátions adsorvidos em torno das partículas de argila, permitindo que os vírus se aproximem das partículas de argila e que sejam mais fortemente atraídos (BOUWER, 1984).

O processo mais intenso de retardamento do vírus no solo acontece por adsorção, porém este mecanismo de retenção do vírus nas paredes dos grãos de solo pode não ser permanente, ou seja, os vírus podem eventualmente desagregar das partículas sólidas, retornar a solução, e continuar se movimentando (BALES et al., 1991; BALES et al., 1993).

Para alguns autores (VILKER \& BURGE, 1980; CORAPCIOGLU \& HARIDAS, 1984; CORAPCIOGLU \& HARIDAS, 1985; TIM \& MOSTAGHIMI, 1991; PARK et al.; 1994; SIM 
\& CHRYSIKOPOULOS, 1995; CHRYSIKOPOULOS \& $\quad$ SIM, 1996; $\quad$ SIM \& CHRYSIKOPOULOS, 1996), os vírus são tão pequenos que teriam um comportamento semelhante ao de um soluto, e a equação de transporte dispersivo-convectivo (FETTER, 1999) descreveria parte dos mecanismos de transporte dos vírus em meio poroso.

\subsection{Tracadores biológicos}

KESWICK et al. (1982) fazem uma revisão dos trabalhos que utilizam microrganismos como traçadores. Aqueles autores mostram que alguns microrganismos - que não são naturalmente encontrados nas águas subterrâneas - podem ser utilizados como traçadores, desde que observados os cuidados necessários na manipulação destes. Os autores recomendam a utilização de bacteriófagos para simular o transporte de vírus humanos nas águas subterrâneas, já que eles não são patogênicos ao homem, são estáveis, semelhantes aos vírus e fáceis de serem detectados.

Os bacteriófagos (ou fagos) são vírus cujos hospedeiros são bactérias. O colifago T4 é um exemplo de bacteriófago utilizado como traçador em diversos estudos (TANIMOTO et al., 1968 apud GERBA et al., 1975; HORI et al., 1971 apud GERBA et al., 1975; YOUNG \& BURBANK, 1973 apud GERBA et al., op. cit.; FLETCHER \& MEYERS, 1974; NOONAN \& MCNABB, 1979 apud KESWICK et al., 1982).

De taxonomia conhecida (Quadro 3.3), o T4 é um vírus complexo, formado por: cabeça (ou capsídeo) em forma de icosaedro (poliedro de 20 faces), com um diâmetro aproximado de 85 nm, pescoço e cauda helicoidal com filamentos na sua extremidade (Figura 3.1). Para infectar o hospedeiro, o T4 adere-se à bactéria através desses filamentos, interagindo com os polissacarídeos da membrana externa e provocando um pequeno furo nela. Em seguida, retrai os filamentos, dando lugar à cauda por onde é injetado o DNA que está armazenado dentro do capsídeo. Depois da infecção, ocorre a replicação, transcrição e tradução da informação genética, produzindo novos fagos que, ao romperem a membrana celular da bactéria, são liberados no meio externo aquoso (MADIGAN et al., 1997).

Veremos adiante que o T4 foi escolhido como traçador biológico, para simular o transporte dos vírus humanos no cemitério, através de estudos em colunas de solo em laboratório. 
Quadro 3.3. Taxonomia do colifago T4

\begin{tabular}{|ll|}
\hline Código do vírus & ICTV: 43.0.1.0.001; ATCC: 11303-B4 \\
\hline Gênero & colifago do grupo T4 \\
\hline Família & Myoviridae \\
\hline Ordem & Caudovirales \\
\hline $\begin{array}{l}\text { Características } \\
\text { principais }\end{array}$ & $\begin{array}{l}\text { Fagos com cauda contrátil, longa }(113 \text { x 16 nm) e complexa, consistindo } \\
\text { de um tubo central envolto por uma bainha contrátil separada da cabeça } \\
\text { por um pescoço. Apresentam capsídios relativamente grandes. }\end{array}$ \\
\hline Ácido nucléico & $\begin{array}{l}\text { Contém uma molécula circular de DNA de fita dupla, com peso molecular } \\
\text { de } 175 \times 10^{6}, \text { correspondendo a 48\% do peso da partícula. O conteúdo de } \\
\text { G+C é de 35\%, possuem 150-160 genes. }\end{array}$ \\
\hline Replicação & Adsorção à parede celular; infecção virulenta. \\
\hline Hospedeiros & $\begin{array}{l}\text { Enterobactérias. Mais utilizado: Escherichia coli (Migula), chamada } \\
\text { Castellani \& Chalmers, designada Escherichia coli B. ATCC: } 11303\end{array}$ \\
\hline
\end{tabular}

Fonte: ICTV (1995) e AMERICAN TYPE CULTURE COLLECTION - ATCC (2000).

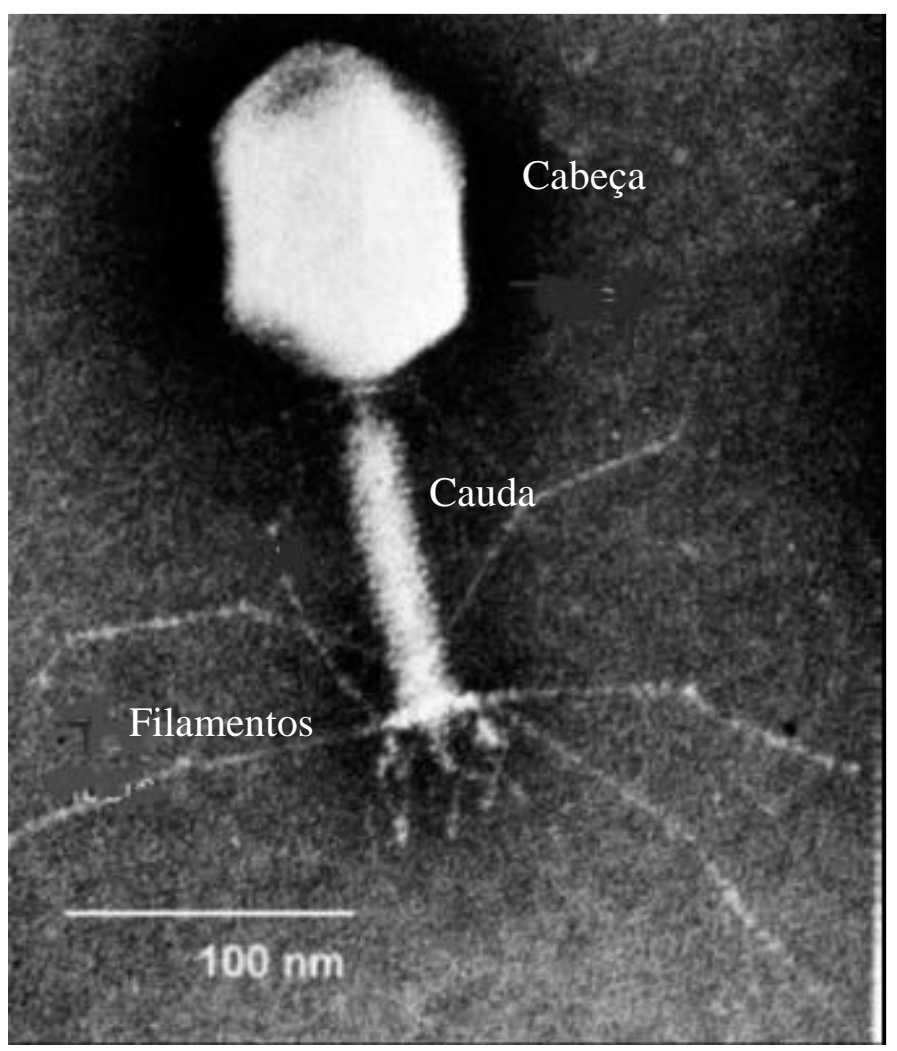

Figura 3.1 Fotomicrografia do bacteriófago T4 Fonte: ICTV (2000). 


\section{4 ÁREA DE ESTUDO}

\subsection{Localização, acesso e área}

O cemitério de Vila Nova Cachoeirinha está localizado no bairro de mesmo nome, na Zona Norte do município de São Paulo (46 40'10”W e 2328'40”S), distando cerca de 9 km do marco zero da cidade (Figura 4.1). O acesso ao local é fácil, podendo ser realizado através da Marginal Tietê, tomando a ponte da Freguesia do Ó e seguindo em direção norte na Av. Inajar de Sousa e Av. Dep. Emílio Carlos (Figura 4.2).

O cemitério possui uma área de $360.000 \mathrm{~m}^{2}$, sendo menor apenas que o cemitério de Vila Formosa $\left(763.000 \mathrm{~m}^{2}\right)$, na cidade de São Paulo. Localizado em uma região dinâmica e de intensa urbanização, o em torno do cemitério é, em grande parte, constituído por residências e apartamentos modestos; pequenas casas de comércio, como floriculturas, lanchonetes, supermercados, panificadoras e lojas de material de construção; hospital e maternidade de Vila Nova Cachoeirinha; terminal de ônibus; Colégio 14 de Julho; Administração Regional da Freguesia do Ó; favela Boi Malhado e favela Morro da Esperança.

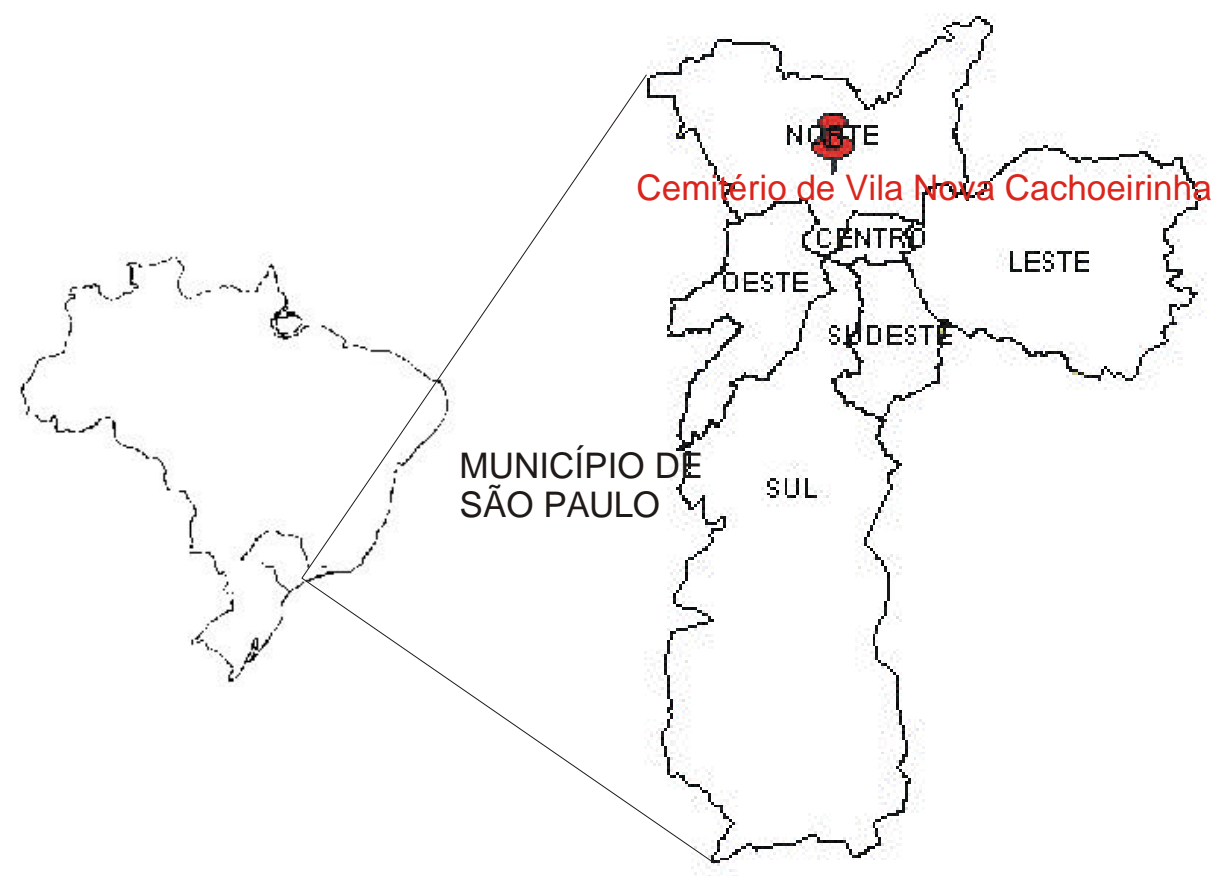

Figura 4.1 Localização do cemitério de Vila Nova Cachoeirinha 


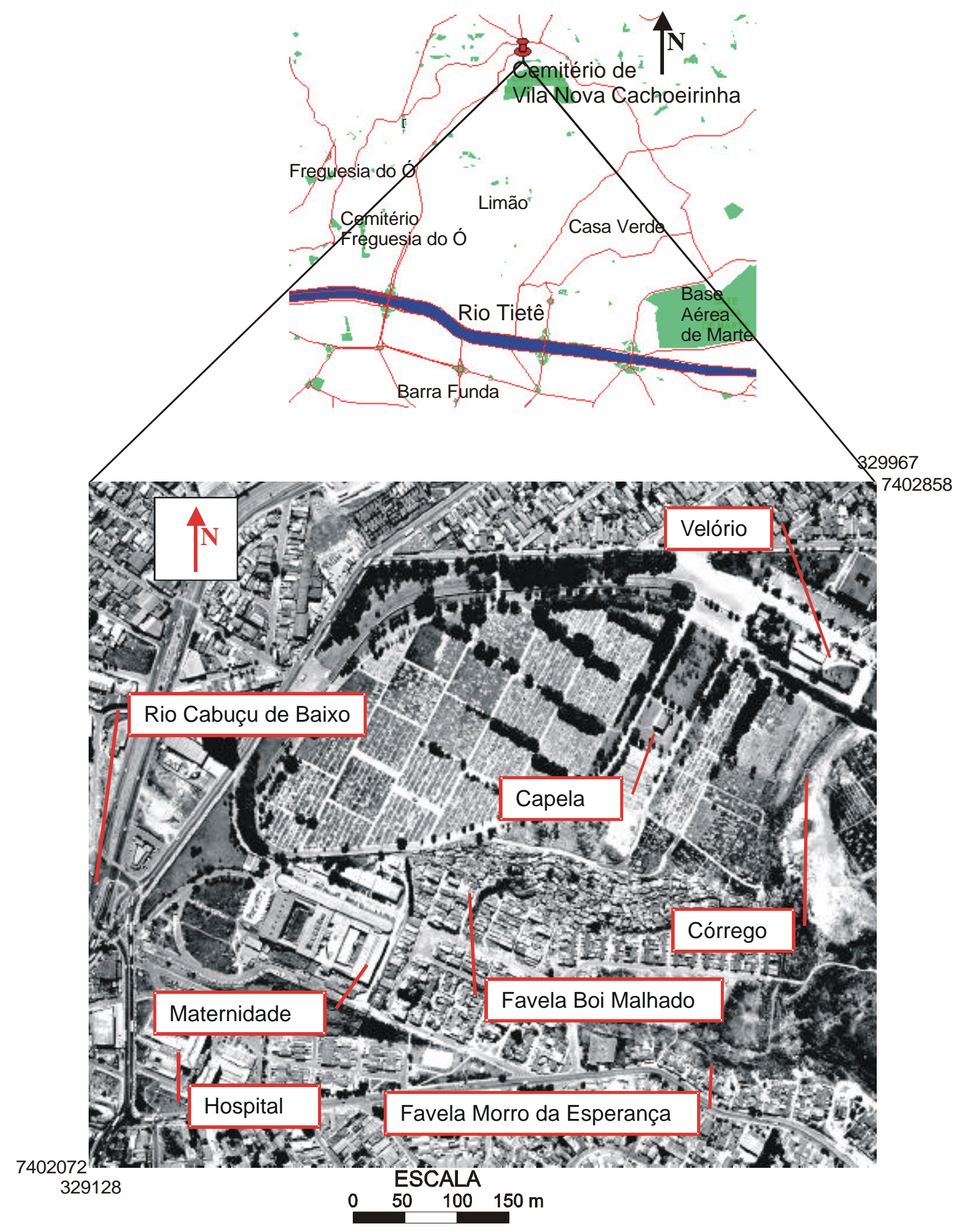

Figura 4.2 Aerofoto do cemitério de Vila Nova Cachoeirinha Fonte: BASE (1996). Coordenadas em UTM. 


\subsection{Histórico}

Em operação desde dezembro de 1968, o cemitério de Vila Nova Cachoeirinha é um dos vinte e um cemitérios públicos administrados pelo Serviço Funerário do Município de São Paulo (SFMSP).

O cemitério possui áreas construídas para administração, recepção, capela, velório, necrotério (desativado), depósito de materiais e ferramentas, vestiários, instalações sanitárias para empregados e para o público, de acordo com o Artigo 156 (Anexo 1) do Código Sanitário Estadual (SÃO PAULO, 1991). Está dividido em quadras, predominando o sepultamento por inumação no solo (caixão colocado diretamente na cova), com pequena cobertura de terra. Não há construções do tipo mausoléu, o cemitério ainda possui um columbário subterrâneo com nichos destinados a receber as urnas funerárias.

Semelhante a outros cemitérios municipais de construção recente, as sepulturas do cemitério de Vila Nova Cachoeirinha, em sua expressiva maioria, não são perpétuas, havendo reutilização das covas. Após um período mínimo de três anos para adultos e dois para crianças, os restos mortais são retirados da sepultura e dispostos em ossuários construídos ao longo do muro do cemitério. Caso o corpo não esteja decomposto, caracterizando um estado de conservação (saponificação ou mumificação), o mesmo permanece no local por mais algum tempo (o Código Sanitário não faz referência a este problema) até que o processo de decomposição seja efetivado. Conforme a administração do cemitério, aproximadamente $25 \%$ dos corpos exumados estão em estado de conservação. Isso levou a administração do cemitério a desistir da realização de sepultamentos em algumas quadras onde o nível freático encontra-se próximo da superfície.

Até seis de fevereiro de 2001 , foram sepultadas $190.066^{1}$ pessoas no local. Segundo o Programa de Aprimoramento das Informações de Mortalidade no Município de São Paulo (PROAIM) mantido pela Secretaria Municipal da Saúde com o auxílio do Serviço Funerário e da Companhia de Processamento de Dados do Município de São Paulo (PRODAM), as principais causas de morte na cidade entre 1996 e 2000 são: doenças ligadas ao aparelho circulatório (principalmente isquemias do coração) com 21,8\% dos óbitos; seguidas de causas externas como homicídios e acidentes de trânsito $(14,7 \%)$; as doenças respiratórias ocupam a terceira posição

\footnotetext{
${ }^{1}$ Livros da administração do cemitério de Vila Nova Cachoeirinha
} 
com 11,4\%; seguidas de neoplasias (10,8\%); doenças cérebro-vasculares (8,9\%); doenças endócrinas, nutricionais e metabólicas (4\%); problemas perinatais (3,3\%); AIDS (2,8\%); algumas doenças infecciosas e parasitárias (2,8\%); doenças do aparelho digestivo (2,7\%); doenças do aparelho geniturinário $(1,1 \%)$ e outras (Figura 4.3$)$.

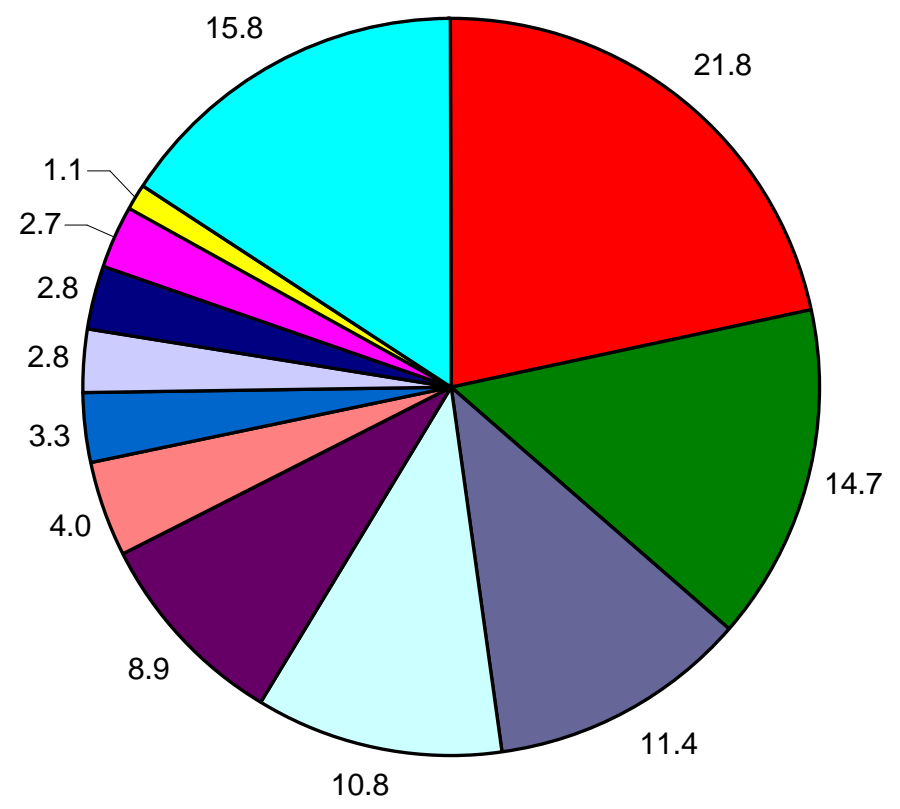

\begin{tabular}{|lll|}
\hline$\square$ Ap. circulatório & $\square$ Causas externas & $\square$ Sist. respiratório \\
$\square$ Neoplasias (Tumores) & $\square$ Sist. nervoso & $\square$ Endóc., nutric. e metab. \\
$\square$ Perinatal & $\square$ Aids & $\square$ Algumas infec. e paras. \\
$\square$ Ap. digestivo & $\square$ Ap. geniturinário & $\square$ Outras \\
\hline
\end{tabular}

Figura 4.3 Principais causas de morte no município de São Paulo (1996-2000) Fonte: PRO-AIM ${ }^{2}$

É usual a falta de cuidados higiênicos e sanitários na operação do cemitério de Vila Nova Cachoeirinha. Pessoas utilizam as águas empoçadas em covas abertas para regar plantas; coveiros executam exumações sem proteção adequada; restos de caixão e vestes funerárias são encontrados dispostos ao ar livre junto com restos de varrição, capina e poda do cemitério. A

${ }^{2}$ Banco de dados do PRO-AIM. Secretaria Municipal da Saúde/Serviço Funerário do Município de São Paulo/Companhia de Processamento de Dados do Município de São Paulo. 
disposição final do lixo funerário no cemitério de Vila Nova Cachoeirinha é inadequada. PACHECO et al. (1999) mostram que o lixo citado é transportado para o Aterro Sanitário Bandeirantes por caminhões contratados pelo Serviço Funerário, não tendo o mesmo tratamento dado aos resíduos sólidos gerados pelos serviços de saúde, como recomenda a Norma Técnica L1.040 (Anexo 1) da COMPANHIA DE TECNOLOGIA DE SANEAMENTO AMBIENTAL CETESB (1999), que regulamenta a implantação de cemitérios no Estado de São Paulo.

No período de chuvas mais intensas pode ocorrer o empoçamento de água nas sepulturas, com o conseqüente extravasamento do necrochorume para a superfície, o qual acaba por escoar nas calçadas e ruelas do cemitério onde circulam pessoas e animais (Figura 4.4). Em março de 2000, a amostra de solo impregnada com aquele líquido mostrou a presença de bactérias proteolíticas (9.000 NMP/100 mL), enquanto outra amostra de solo do cemitério, sem a presença do mencionado líquido, apresentou menos de $2 \mathrm{NMP} / 100 \mathrm{~mL}$.

Quando este trabalho teve início, em 1997, o extremo sul do cemitério havia sido invadido por famílias das favelas Boi Malhado e Morro da Esperança que construíram suas casas na encosta da elevação que abriga o cemitério, em área de risco geotécnico sujeita a desmoronamentos. Alguns moradores das favelas eram abastecidos pela rede pública da SABESP, e outros entravam com baldes no cemitério para utilizar água das torneiras existentes no local. Como não havia coleta de lixo, as pessoas o lançavam para dentro do cemitério, por cima do muro parcialmente destruído. O esgoto doméstico era lançado no pequeno córrego que atravessa a área de estudo e deságua no rio Cabuçu de Baixo. Mesmo a montante das favelas, este córrego já apresentava números elevados de coliformes totais (>16.000 NMP/100 mL), fecais (>16.000 NMP/100 mL) e clostrídios sulfito-redutores (230 NMP/100 mL), demonstrando a contribuição direta de esgotos ou outra fonte de contaminação de origem humana ou animal (MATOS et al., 1998).

Durante o desenvolvimento do trabalho, foi comum observar a utilização do espaço cemiterial para lazer de crianças (às vezes, sem calçados ou mesmo roupas), tráfico e consumo de drogas, assaltos e outros. REZENDE (2000) também observou a utilização do cemitério de Vila Formosa para atividades lúdicas, devido à carência de espaços adequados na cidade de São Paulo.

Dezesseis anos após o primeiro projeto habitacional (REINACH, 1984) para construção de casas e urbanização das favelas Boi Malhado e Morro da Esperança, o qual nunca foi concluído, os moradores foram removidos para um novo conjunto habitacional construído no 
sopé do Morro da Esperança. Porém, até o momento, não houve recuperação da área ocupada pelos barracos, estando sujeita a novas invasões.

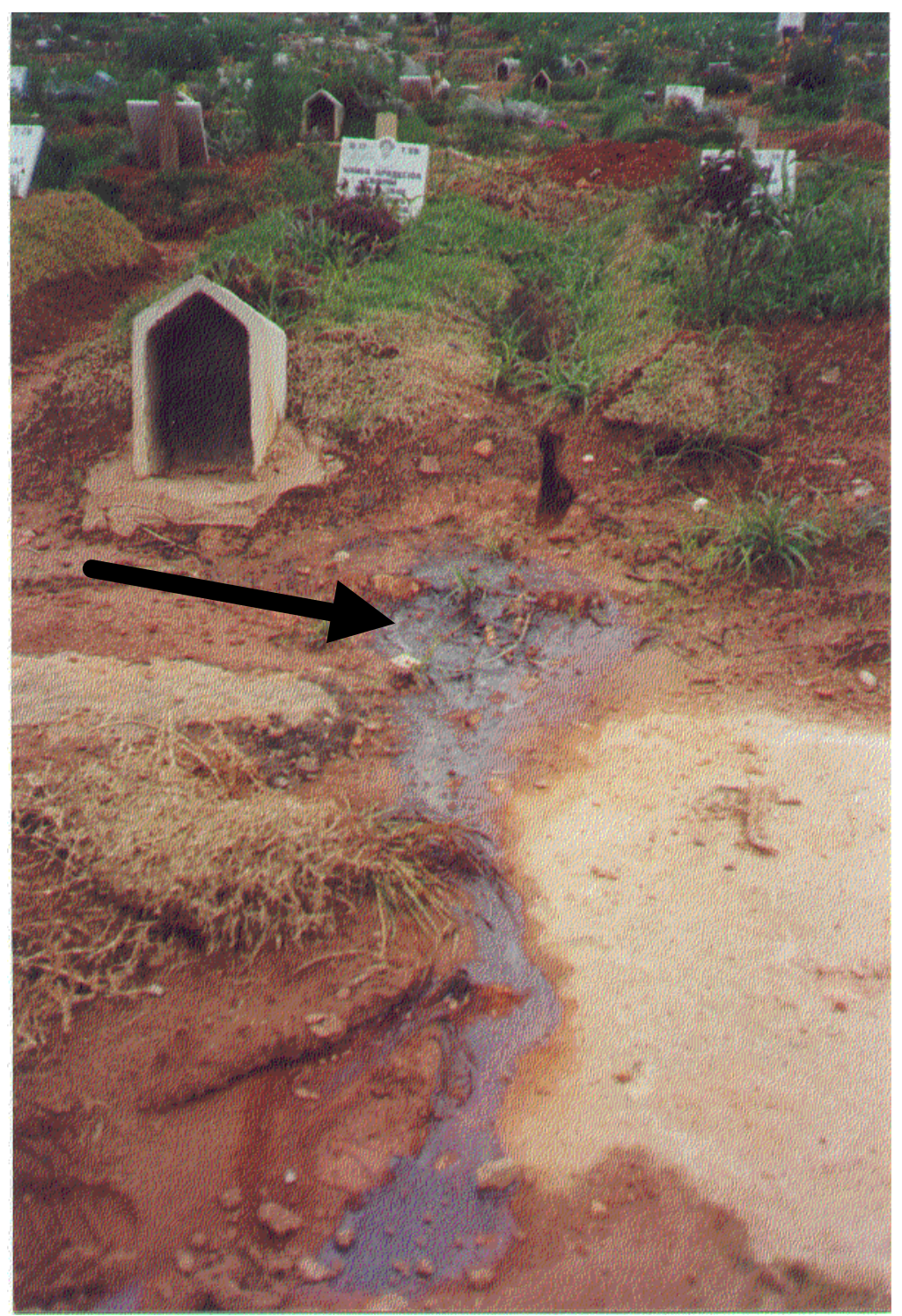

Figura 4.4 Extravasamento do necrochorume (março de 2000) Fonte: MATOS \& PACHECO, 2000. 


\section{3 $\quad$ Geologia}

A Região Metropolitana de São Paulo (RMSP) está sobrejacente às rochas cristalinas, metamórficas e ígneas (85\% da área) de idade Pré-Cambriana e às rochas sedimentares do Cenozóico (DEPARTAMENTO DE ÁGUAS E ENERGIA ELÉTRICA - DAEE, 1975). O cemitério de Vila Nova Cachoeirinha está localizado sobre o manto de alteração das rochas granitóides intrusivas que formam o maciço da Cantareira, próximo aos limites da bacia sedimentar de São Paulo.

O maciço da Cantareira "compreende um corpo de forma aproximadamente triangular, alongado segundo a direção NE-SW, estendendo-se desde os bairros de Pirituba-Vila Guedes (região norte da Capital), até o bairro Pirucaia (município de Mairiporã)" (DANTAS, 1990). A rocha é composta essencialmente por minerais de plagioclásio, biotita, microclíneo e quartzo (DAEE, op. cit), dominando um caráter cálcio-alcalino peraluminoso (DANTAS, op. cit.).

Aquele autor realizou o mapeamento geológico da área compreendida pela Folha Guarulhos (INSTITUTO BRASILEIRO DE GEOGRAFIA E ESTATÍSTICA - IBGE, 1984), inferindo um contato próximo ao limite da área do cemitério, entre as rochas do maciço da Cantareira $\left(\gamma_{2} \mathrm{C}_{1}\right)$ e as rochas calciossilicáticas ( $\mathrm{SiCs}$ ), como mostra a Figura 4.5. Segundo o autor, no local, a passagem dos granitóides para os metassedimentos do Grupo São Roque e ortognaisses do embasamento é mascarada pelo manto de alteração e pela ocupação urbana.

MENDES et al. (1989) realizaram 6 sondagens elétricas na parte oeste do cemitério e verificaram que o topo da rocha sã fica entre 8 e 36 metros no local. A descrição litológica ${ }^{3}$ de um poço tubular construído pela GEOPLAN Poços Artesianos no Hospital Vila Nova Cachoeirinha (300 $\mathrm{m}$ a sudoeste da área estudada) mostra que a rocha granítica encontra-se a 12 $\mathrm{m}$ de profundidade no local (Figura 4.6). Dois poços ${ }^{4}$ perfurados pela JUNDSONDAS Poços Artesianos (800 $\mathrm{m}$ a sudoeste do cemitério) também apresentaram descrições litológicas semelhantes ao poço citado, um deles encontrando a rocha granítica a $18 \mathrm{~m}$ de profundidade.

\footnotetext{
${ }^{3}$ Ficha do poço tubular profundo fornecida pela Secretaria de Saúde do Estado de São Paulo (Hospital Vila Nova Cachoeirinha).

${ }^{4}$ Banco de dados de poços do DAEE da Secretaria de Recursos Hídricos Saneamento e Obras do Estado de São Paulo.
} 

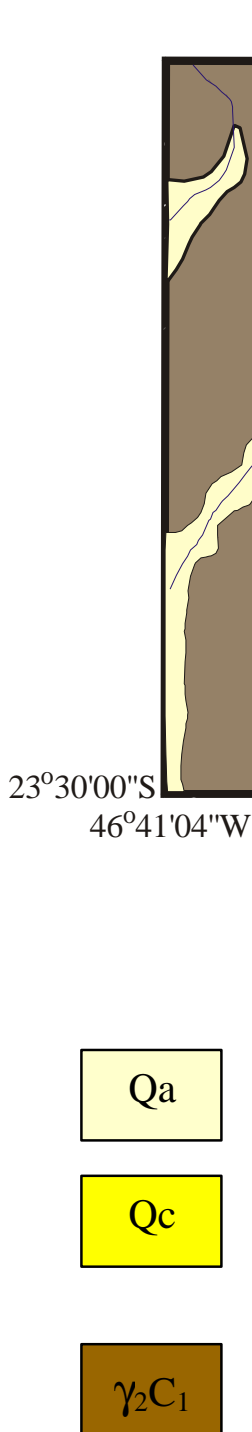

\section{DESCRIÇÃO DAS UNIDADES LITO-ESTRATIGRÁFICAS}

\section{COBERTURAS CENOZÓICAS}

Depósitos aluvionares e colúvio-eluvionares. Areias, siltes e argilas preenchendo várzeas atuais.

Depósitos colúvio-eluvionares. Coberturas síltico-argilosas, argilo-arenosas com pedregulhos esparsos na matriz.

\section{ROCHAS GRANITÓIDES INTRUSIVAS}

Biotita granodioritos e granodioritos, com variações monzograníticas a quartzomonzodioríticas, textura porfiróide, com megacristais subédricos a euédricos de microclínio. Matriz tonalítica-granodiorítica orientada a isótropa.

GRUPO SÃO ROQUE, UNIDADE SUPERIOR

SiCs Metassedimentos químico-detríticos. Rochas calciossilicáticas.

\section{EMBASAMENTO PRÉ-SÃO ROQUE}

Ortognaisses miloníticos a blastomiloníticos. Rochas leucocráticas, cinza clara a rósea, de estrutura gnáissica maciça

Contato definido

$$
\text { CONVENÇÕES GEOLÓGICAS }
$$

Contato inferido
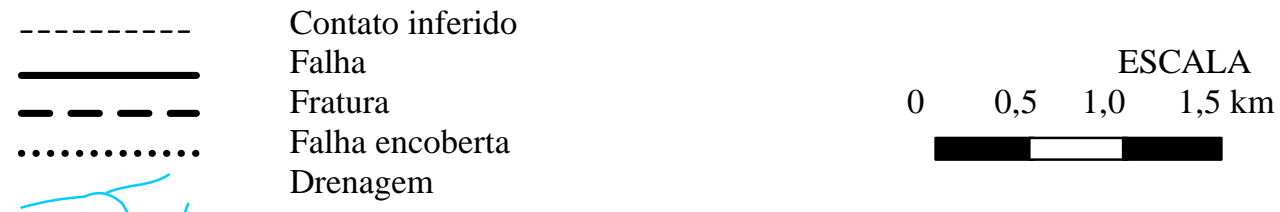

Figura 4.5 Mapa geológico da área.

Fonte: Adaptado de DANTAS (1990). 


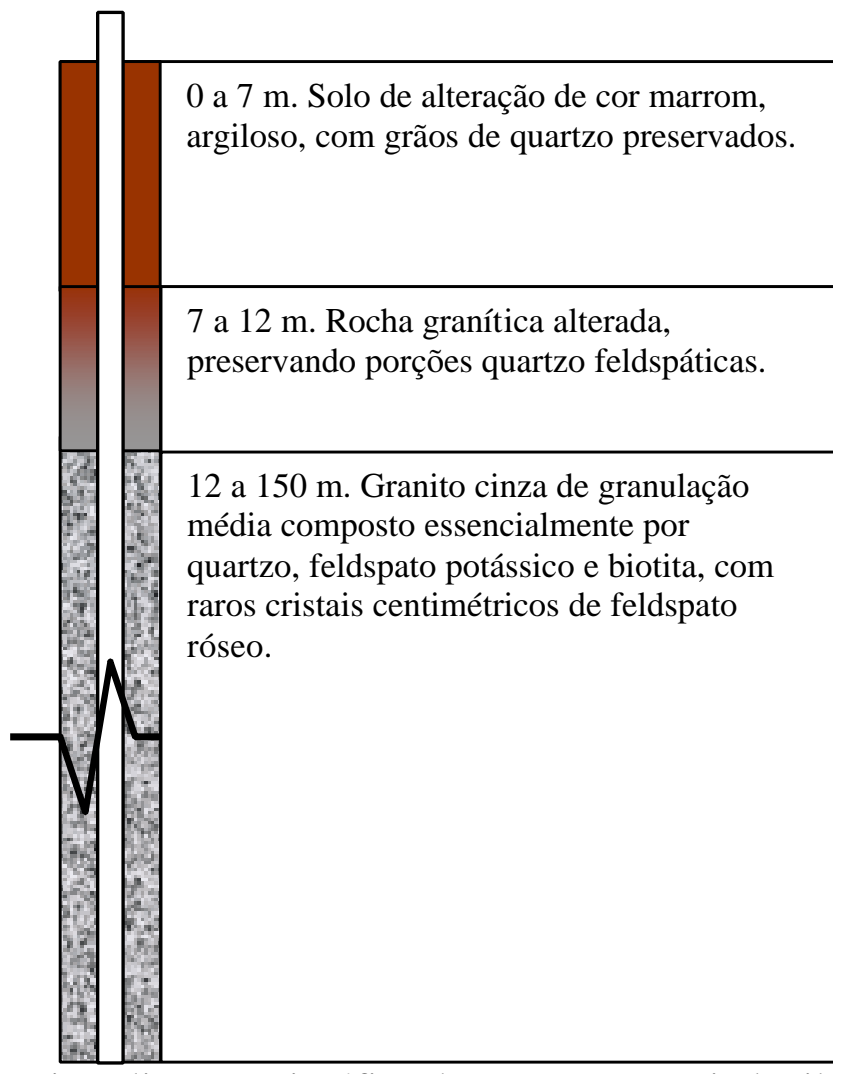

Figura 4.6 Descrição lito-estratigráfica do poço no Hospital Vila Nova Cachoeirinha Obs.: Perfil da GEOPLAN Poços Artesianos

\subsection{Geomorfologia}

Situado na unidade morfológica denominada Planalto Paulistano e inserido na bacia hidrográfica do Alto Tietê, o cemitério de Vila Nova Cachoeirinha encontra-se em terrenos de relevo formado por morros médios e altos com topos convexos (ROSS \& MOROZ, 1997), em acordo com o Artigo 151 (Anexo 1) do Código Sanitário Estadual (SÃO PAULO, 1991), que afirma que os cemitérios devem ser construídos em áreas elevadas. No local, as altitudes estão entre 745 e $781 \mathrm{~m}$ e as declividades variam de 12 a 15\% (Figura 4.7). Os sepultamentos são realizados ao longo de suas vertentes.

A drenagem apresenta um padrão dendrítico, às vezes obedecendo às direções estruturais regionais, mas em alguns casos pode ter traçados independentes. Com vales entalhados e densidade de drenagem média a alta, essa área apresenta um nível de fragilidade potencial médio, estando sujeita a fortes atividades erosivas (ROSS \& MOROZ, op. cit.). 


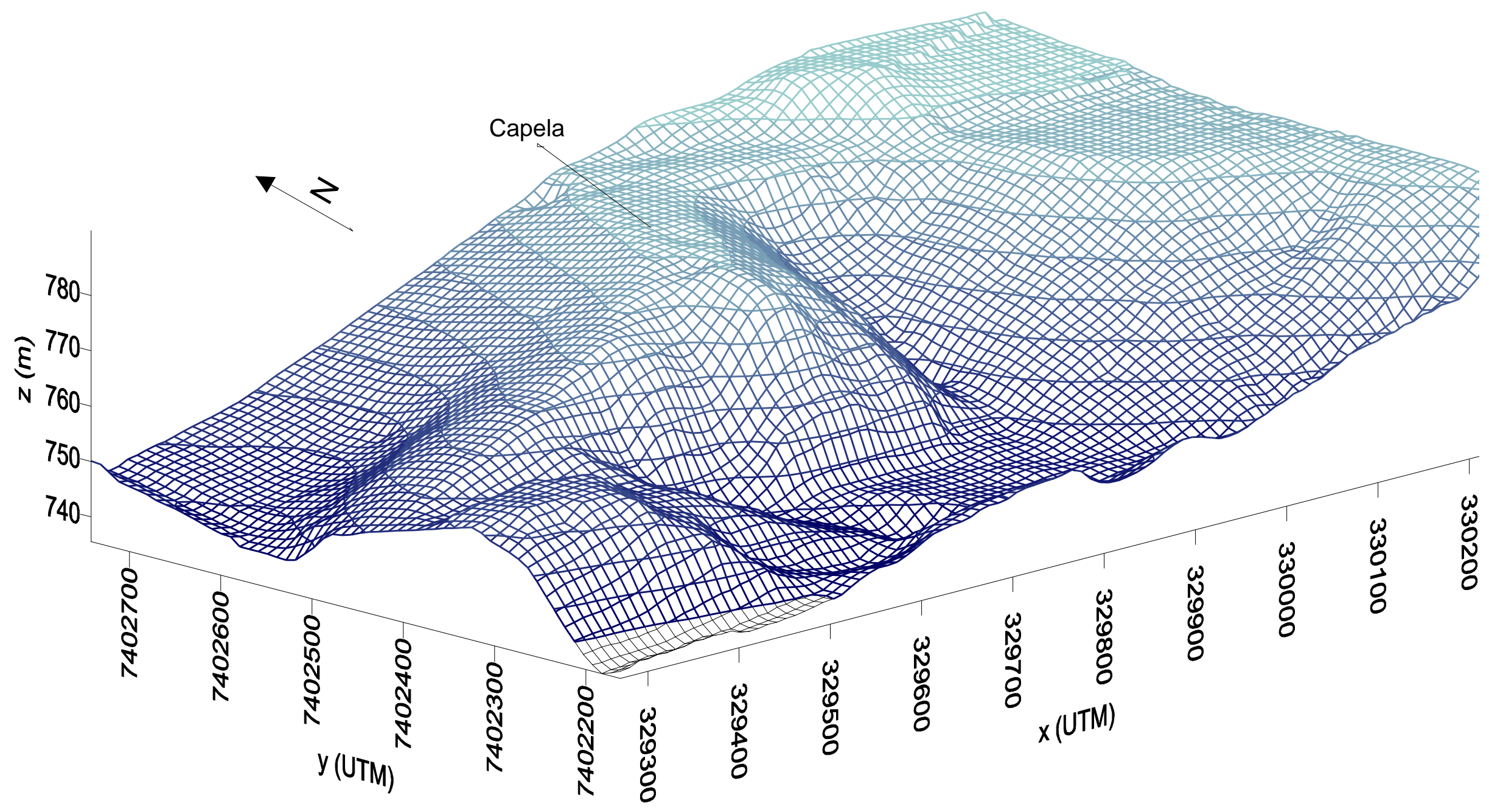

Figura 4.7 Altimetria do cemitério de Vila Nova Cachoeirinha Adaptado de EMPLASA (1974a, 1974b, 1974c, 1974d) 


\subsection{Solos}

Em geral, os solos ao norte da malha urbana da cidade são do tipo argissolos vermelhoamarelos. São solos com nítida diferenciação entre os horizontes, com teor de argila do horizonte B bem mais elevado que o horizonte A. Esses solos são ácidos e com saturação de bases baixa (LEPSCH, 1975). De acordo com OLIVEIRA et al. (1999), são solos com baixa capacidade de troca de cátions $(<27 \mathrm{cmol} / \mathrm{kg})$.

O solo do cemitério é proveniente da alteração de granitos. Amostras de uma sondagem geológica realizada por TÔRRES (1992a), na porção oeste do cemitério, mostraram a predominância de materiais argilosos e argilo-arenosos, em que a porosidade média, determinada em lâminas, diminui de 9,8 para 2,12\% com o aumento da profundidade, em um perfil de 0 a 4 $\mathrm{m}$. As análises realizadas pelo autor indicam a seguinte característica para o perfil:

0 - 1 m: caráter areno-argiloso, porosidade entre 8,50 e 9,80\%;

1 - 1,50 m: sedimentos argilo-arenosos com decréscimo da porosidade (6,46 a 7,29\%);

1,50 - 2,00 m: material predominantemente argiloso com porosidade entre 1,70 e 7,21\%;

2,00 - 2,60 m: aumento da porosidade de 1,70 para 5,78\%;

2,60 - 3,50 m: material estritamente argiloso, porosidade entre 1,02 e 5,44\%;

3,50 m: incremento da porosidade de 1,02 para 4,30\%;

4,00 m: composta de argilominerais com porosidade de 2,12 a 4,30\%.

Para TÔRRES (op. cit.), os contrastes de porosidade, observados entre 2,0 e 2,60 m e a 3,5 m, indicam a presença de materiais com menor teor de argila, formando horizontes mais arenosos.

\subsection{Precipitacão e clima}

A cidade de São Paulo tem precipitação média anual de 1.300 mm (DAEE, 1975), sendo que as chuvas são mais intensas durante o verão do hemisfério sul, como mostra a Figura 4.8. As chuvas no cemitério foram estimadas a partir do posto pluviométrico Santana (Código: E3-071, 
Altitude: $760 \mathrm{~m}$, Latitude: $23^{\circ} 30^{\prime} \mathrm{S}$, Longitude: $\left.46^{\circ} 36^{\prime} \mathrm{W}\right)$ que está em operação desde 1936 (DAEE, 1998). Neste posto, a precipitação média é de $1.400 \mathrm{~mm}$ por ano.

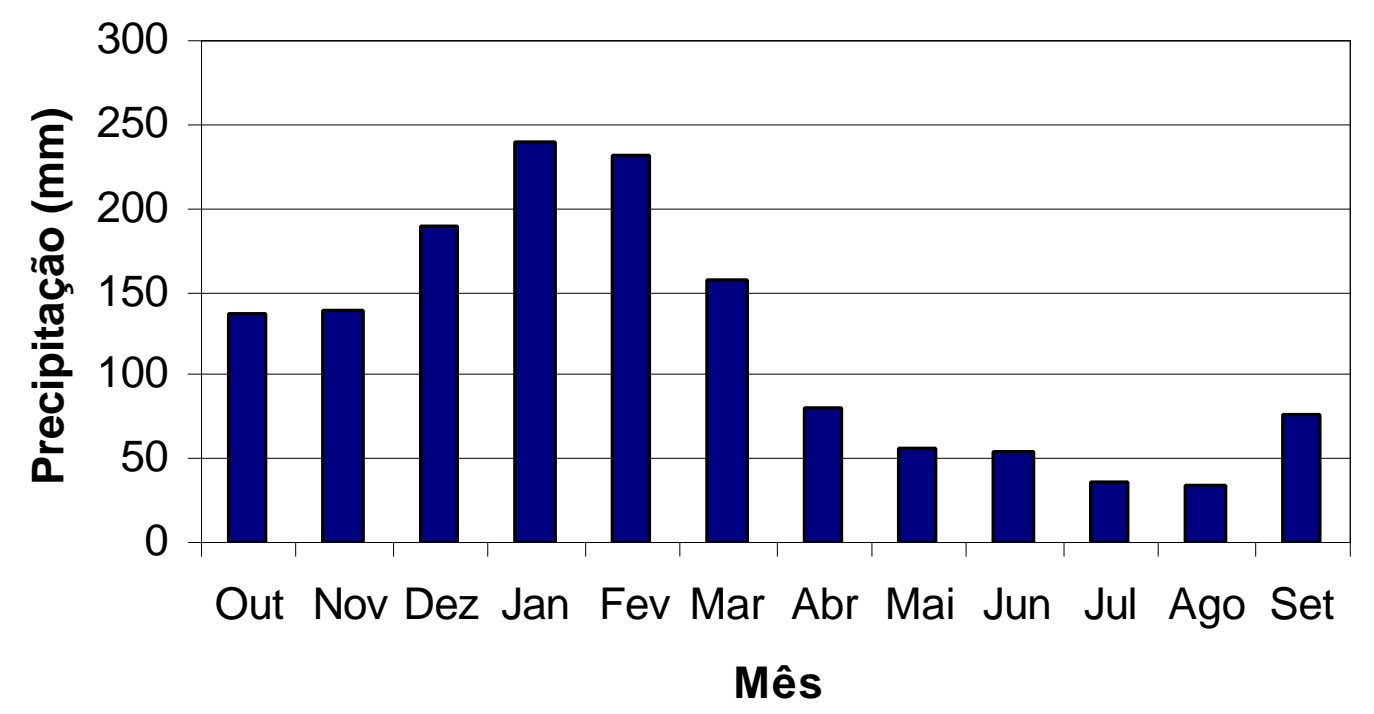

Figura 4.8 Precipitação mensal média (Posto Santana) Fonte: DAEE (1998)

A precipitação na Zona Norte da cidade é influenciada por efeitos orográficos locais e, principalmente, pelo clima da região, que segundo SILVA (2000), é do tipo tropical temperado de altitude. A temperatura média anual é de $25^{\circ} \mathrm{C}$, e as médias mensais oscilam entre $27^{\circ} \mathrm{C}$, em fevereiro, e $12-14^{\circ} \mathrm{C}$, em julho. A evaporação potencial fica entre 1.000 e $1.300 \mathrm{~mm}$ por ano (DAEE, 1975).

A chuva na cidade de São Paulo tem um caráter ácido com elevada concentração de íons, principalmente sulfato, nitrato e cloreto, devido às atividades antrópicas (CASTRO, 1993). MOREIRA-NORDEMANN et al. (1985) obtiveram um pH médio de 4,9 em amostras coletadas na Cidade Universitária e teores elevados de $\mathrm{SO}_{4}{ }^{2-}(2,05 \pm 3,32 \mathrm{mg} / \mathrm{L}), \mathrm{NO}_{3}{ }^{-}(2,17 \pm 1,33), \mathrm{Cl}^{-}$ $(0,71 \pm 1,17), \mathrm{Ca}^{2+}(0,92 \pm 0,80) \mathrm{e} \mathrm{NH}_{4}{ }^{+}(0,82 \pm 0,55)$. CASTRO (op. cit.) obteve pH médio de 4,74 em amostras de chuva coletadas principalmente na Vila Clementino. A autora observou uma sazonalidade nos dados, com águas ligeiramente mais ácidas no outono-inverno ( $\mathrm{pH}$ médio $=4,60)$. 


\subsection{Bacia hidrográfica}

O cemitério de Vila Nova Cachoeirinha está situado a $100 \mathrm{~m}$ da margem esquerda do rio Cabuçu de Baixo, afluente do rio Tietê, à margem direita. A bacia hidrográfica do rio Cabuçu de Baixo (Figura 4.9) tem aproximadamente $50 \mathrm{~km}^{2}$, sua drenagem - e de seus pequenos tributários - é influenciada pela intensa urbanização da área, desde o limite da Reserva Florestal da Cantareira (região da nascente) até a foz, que está situada próxima da ponte da Freguesia do Ó. É notável a intervenção no escoamento natural pelos processos antrópicos de impermeabilização do solo e canalização do rio e de córregos. Comum em áreas urbanas brasileiras, o rio Cabuçu de Baixo é utilizado para escoar parte dos resíduos sólidos e esgotos gerados naquela região.

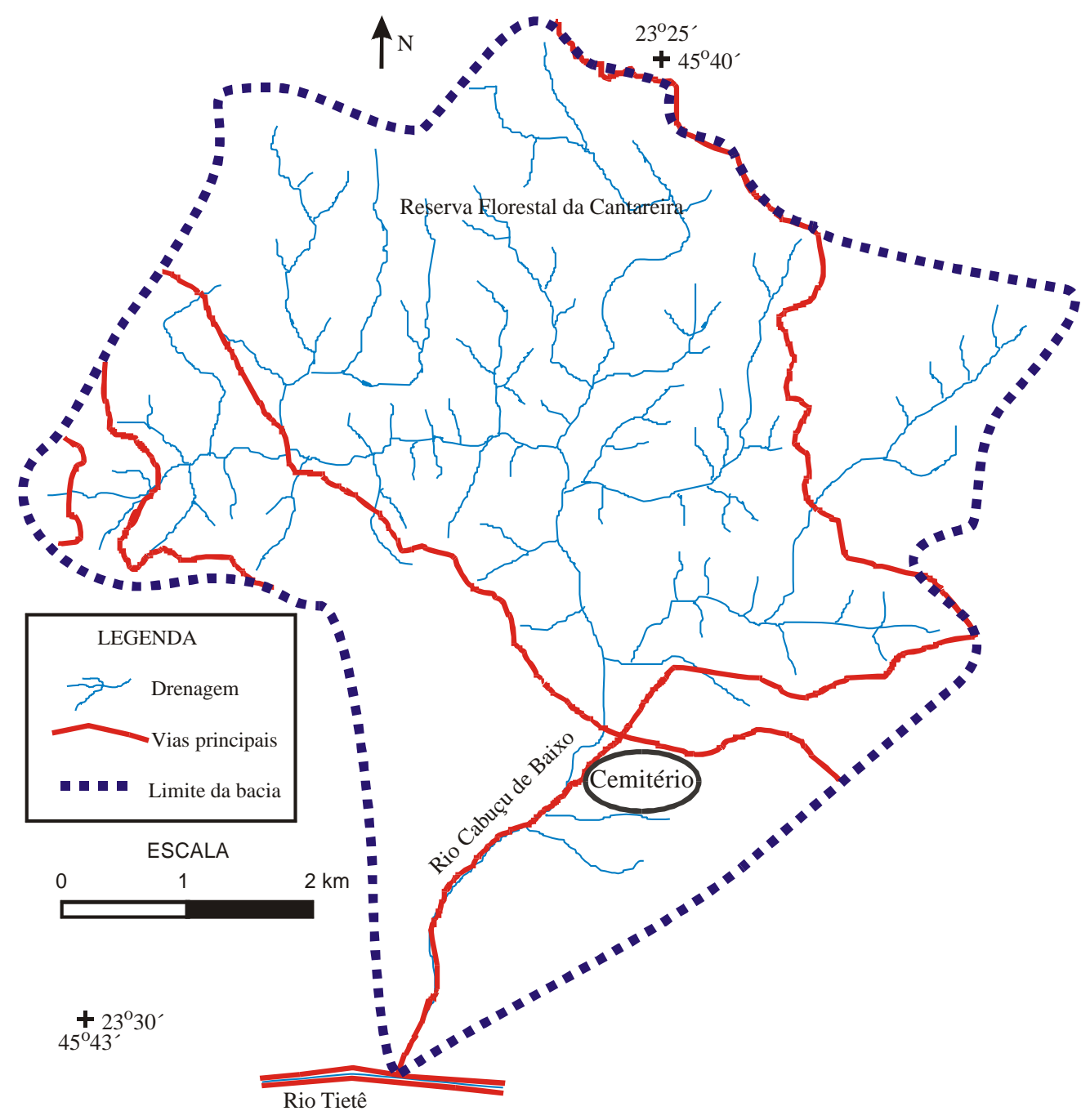

Figura 4.9 Bacia hidrográfica do rio Cabuçu de Baixo

Fonte: Adaptado de IBGE (1984) 


\section{8}

As águas subterrâneas na RMSP são explotadas de dois sistemas aqüíferos principais, o cristalino e o sedimentar da bacia de São Paulo.

O sistema aqüífero cristalino na RMSP pode ser dividido em duas unidades distintas. A parte superior, com espessura média de $50 \mathrm{~m}$, é formada por materiais de caráter argiloso procedentes do manto de intemperismo das rochas subjacentes e por depósitos alóctones, enquanto a parte inferior é constituída pela rocha sã fraturada, apresentando características de aqüífero livre ou localmente confinado (DAEE, 1975). REBOUÇAS \& CAVALCANTE (1987) apud MENEGASSE (1991) apresentam as seguintes características hidráulicas para o aqüífero cristalino:

1. Terço superior do perfil: $K=10^{-6}$ a $10^{-7} \mathrm{~m} / \mathrm{s}, n_{e}=0,1$ a $2,0 \%$;

2. Zona de material friável: $K=10^{-4}$ a $10^{-5} \mathrm{~m} / \mathrm{s}, n_{e}=2$ a $5,0 \%$;

3. Zona de rocha fraturada: $K=10^{-3}$ a $10^{-5} \mathrm{~m} / \mathrm{s}$.

No cemitério de Vila Nova Cachoeirinha, as sondagens elétricas realizadas na parte oeste mostraram que o nível freático estava em profundidades de 4 a 9 metros (MENDES et al. 1989). As sondagens também indicaram a existência de aqüífero suspenso no local. Piezômetros construídos por TÔRRES (1992b), no extremo oeste do local, mostram que o nível freático encontra-se entre 4,30 e 5,30 $\mathrm{m}$ de profundidade.

Em geral, as águas subterrâneas na bacia do Alto Tietê, tanto no sistema aquiúfero cristalino quanto na bacia sedimentar de São Paulo, apresentam baixas concentrações de íons (DAEE, op. cit.), sendo que o ânion predominante é o $\mathrm{HCO}_{3}{ }^{-}$e o cátion é o $\mathrm{Ca}^{2+}$. A condutividade elétrica dessas águas é baixa, com totais de sólidos dissolvidos inferiores a $500 \mathrm{mg} / \mathrm{L}$ (REBOUÇAS, 1992) e o pH é ácido, oscilando entre 5 e 6,5 (DAEE, op. cit.). Às vezes, as águas apresentam teores restritivos de ferro, apesar de raramente ultrapassarem $5 \mathrm{mg} / \mathrm{L}$ (PARISOT, 1983). O Quadro 4.1 mostra o pH, a condutividade elétrica e os íons predominantes em alguns estudos realizados na RMSP.

PARISOT (1983) observou que as águas do aqüífero cristalino (profundidade média dos poços amostrados de 150 a $250 \mathrm{~m}$ ) são mais mineralizadas que as do sedimentar (profundidade média dos poços amostrados de 100 a $200 \mathrm{~m}$ ), apresentando nítido aumento de $\mathrm{Na}^{+}, \mathrm{Ca}^{2+}$ e $\mathrm{HCO}_{3}{ }^{-}$. A autora mostra que as águas do aqüífero cristalino são classificadas como águas 
bicarbonatadas cálcicas e sódicas, enquanto as águas do outro são bicarbonatadas sódicas e potássicas.

Quadro 4.1. Propriedades das águas subterrâneas da RMSP

\begin{tabular}{|lcccl|}
\hline \multicolumn{1}{|c}{ Local } & pH & $\begin{array}{c}\text { Cond. Elét. } \\
(\mu \mathrm{S} / \mathrm{cm})\end{array}$ & $\begin{array}{c}\text { Íons } \\
\text { predominantes }\end{array}$ & \multicolumn{1}{c|}{ Fonte } \\
\hline $\begin{array}{l}\text { Centro-Oeste do } \\
\text { município de São Paulo }\end{array}$ & $5-8$ & $5-760$ & $\mathrm{HCO}_{3}^{-}, \mathrm{Na}^{+}, \mathrm{Ca}^{2+}$ & PARISOT (1983) \\
Cidade Universitária & $5-6$ & $27-185$ & $\mathrm{HCO}_{3}^{-}, \mathrm{Ca}^{2+}$ & SZIKSZAY et al. (1990) \\
Cidade Universitária & $3-7$ & $36-690$ & $\mathrm{HCO}_{3}^{-}, \mathrm{SO}_{4}^{2-}, \mathrm{Ca}^{2+}$ & IRITANI (1993) \\
NW da RMSP & $5-8$ & $88-370$ & $\mathrm{HCO}_{3}^{-}, \mathrm{Ca}^{2+}$ & MENEGASSE (1991) \\
Sumaré e Pompéia & $4-7$ & $50-300$ & $\mathrm{HCO}_{3}^{-}, \mathrm{Ca}^{2+}$ & MENEGASSE \\
& & & & VELASQUEZ (1996) \\
Itaquera & $4-7$ & $22-321$ & $\mathrm{HCO}_{3}^{-}, \mathrm{SO}_{4}^{2-}, \mathrm{Ca}^{2+}$ & SILVA (2000) \\
\hline
\end{tabular}

As águas subterrâneas da RMSP são de boa qualidade para o consumo humano (REBOUÇAS, 1992), porém as águas dos aqüíferos mais superficiais, tanto nos sedimentos como no cristalino, estão contaminadas principalmente por esgotos e fossas sépticas (ROSS, 1981). Já os aqüíferos mais profundos são contaminados, fundamentalmente, devido à má qualidade técnica construtiva dos poços tubulares (PACHECO \& REBOUÇAS, 1985).

O Quadro 4.2 mostra os resultados encontrados no cemitério de Vila Nova Cachoeirinha por PACHECO et al. (1991) nos estudos realizados em três cemitérios de São Paulo. Segundo os autores, em Vila Nova Cachoeirinha, o aqüífero do cemitério apresentou números elevados de bactérias heterotróficas e proteolíticas.

Quadro 4.2. Indicadores bacteriológicos estudados no cemitério de Vila Nova Cachoeirinha

\begin{tabular}{|lrrr|}
\hline \multicolumn{1}{|c}{ Indicador } & Máximo & Mínimo & $\begin{array}{c}\text { Média } \\
\text { Geométrica }\end{array}$ \\
\hline Coliformes totais (NMP/100mL) & 1.600 & 27 & 163 \\
Coliformes fecais (NMP/100mL) & 7 & 2 & 2 \\
Estreptococos fecais (NMP/100mL) & 1.600 & 2 & 8 \\
Clostrídios sulfito redutores (NMP/100mL) & 27 & 2 & 7 \\
Bact. proteolíticas (NMP/100mL) & 9.000 & 220 & 1.018 \\
Bact. heterotróficas aeróbias (UFC/mL) & $53 \times 10^{3}$ & 2.800 & 10.821 \\
Bact. het. anaeróbias (UFC/mL) & $16 \times 10^{4}$ & 440 & 16.383 \\
Bact. lipolíticas (UFC/mL) & $36 \times 10^{3}$ & 160 & 3.942 \\
\hline
\end{tabular}

Fonte: PACHECO et al. (1991). 


\section{MATERIAL E MÉTODO}

\subsection{Etapa de laboratório}

As atividades descritas foram realizadas no Laboratório de Microbiologia Ambiental do Instituto de Ciências Biomédicas da Universidade de São Paulo, entre janeiro de 1997 e fevereiro de 2000 .

Os procedimentos empregados visaram o estudo do transporte de vírus em meio poroso. Foram realizados experimentos in vitro para determinar quanto tempo os vírus conseguem sobreviver antes de sofrerem inativação e como são adsorvidos pela matriz sólida através de interações iônicas. Também foi simulado o transporte dos vírus pelo fluxo hidráulico subterrâneo através da injeção de traçadores químico e biológico em colunas de solo proveniente da área de estudo. Um modelo numérico foi ajustado para determinar a dispersão e adsorção do vírus.

\subsubsection{Colunas de solo}

Duas colunas de vidro de base circular (comprimento, $l=50 \mathrm{~cm}$; diâmetro interno, d.i. $=$ $8 \mathrm{~cm}$; espessura, $e=3 \mathrm{~mm}$ ) foram construídas para sustentar amostras deformadas de solo do cemitério de Vila Nova Cachoeirinha.

A superfície interna de cada coluna foi tratada com areia para aumentar a sua rugosidade, diminuindo o fluxo preferencial de água ao longo da parede. Quatro bicos laterais $($ d.i. $=1 \mathrm{~mm})$ foram implantados, espaçados de 14,2 cm: dois nas extremidades, para garantir a entrada e saída de água e dois ao longo da coluna, para a instalação de manômetros; os quatro bicos foram revestidos com filtros de silk-screen para evitar a carreação do solo (Figura 5.1).

Depois de esterilizado em autoclave e seco em estufa, o solo foi disposto no interior da coluna em intervalos de aproximadamente $5 \mathrm{~cm}$ e levemente remexido com uma espátula para evitar a sua estratificação, até atingir cerca de $30 \mathrm{~cm}$.

A coluna de solo foi alimentada, através de mangueiras de silicone, por um bécher de $2 \mathrm{~L}$ adaptado com furos nas extremidades inferior e superior, funcionando como um reservatório de 
nível d'água constante (Figura 5.1). Por sua vez, o reservatório foi abastecido por um barrilete de água destilada com capacidade de $20 \mathrm{~L}$.

Para a saturação do meio, permitiu-se à água descer lentamente por gravidade e penetrar na coluna de baixo para cima, expulsando eventuais bolhas de ar. Após 48 horas, com o sistema estável, iniciou-se o experimento, realizado em temperatura ambiente, com a monitoração da condutividade elétrica, temperatura, $\mathrm{pH}$ e potencial redox do efluente da coluna. Diferentes vazões foram aplicadas através da variação na carga hidráulica $h$. No bico de saída, foram utilizadas provetas para a medição da vazão $Q$ do efluente. A condutividade hidráulica $K$ foi determinada através da regressão linear entre valores observados da velocidade de Darcy $q$ e respectivas medidas do gradiente hidráulico $d h / d l$ observadas entre os dois manômetros.

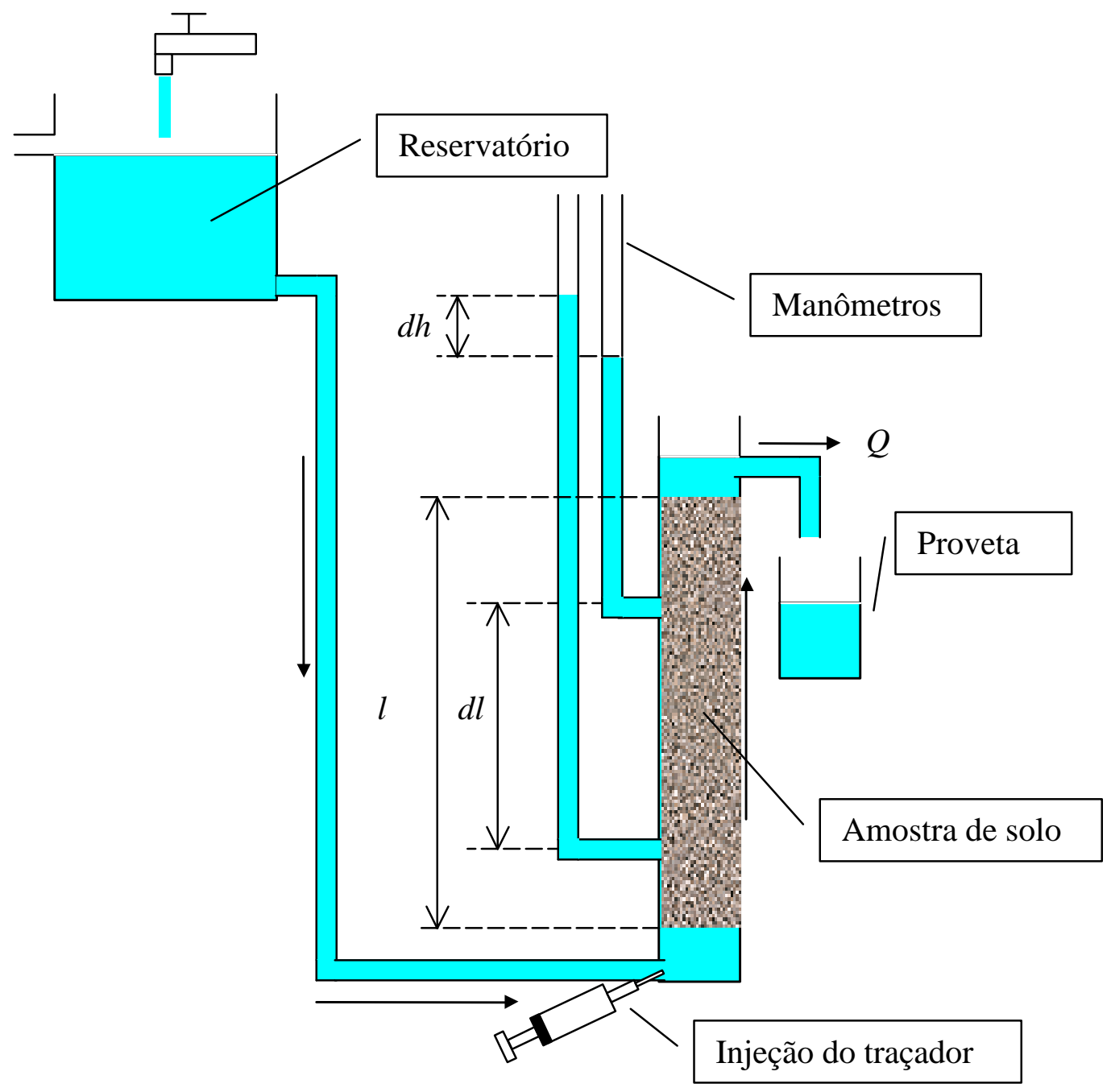

Figura 5.1 Esquema das colunas de solos 
Antes de realizar os experimentos com o solo proveniente do cemitério, a coluna foi preenchida com um solo de textura arenosa (90\% de fração de areia). Desta forma, foi possível comparar o transporte e a retenção dos traçadores químico e biológico entre o solo bastante permeável e o solo do cemitério.

O equipamento utilizado foi autoclave, estufa, colunas de vidro, mangueiras de silicone, espátulas, silk-screen, fitas e cintas de vedação, bécher, barrilete, provetas, trena, cronômetro. Todo o material empregado na montagem foi autoclavado a $121^{\circ} \mathrm{C}$ por $15 \mathrm{~min}$, para a esterilização.

\subsubsection{Seleção do traçador}

O critério para seleção do traçador biológico foi adaptado de KESWICK et al. (1982). O organismo escolhido precisou satisfazer os seguintes itens:

- ter comportamento e característica semelhantes aos de um vírus;

- não deve ser patogênico ao homem, animais ou vegetais;

- estar naturalmente ausente nas águas subterrâneas;

- $\quad$ ser estável no meio ambiente durante o período dos experimentos;

- ser de fácil preparo, atingindo altas concentrações;

- ser de fácil detecção através de métodos econômicos.

Os trabalhos de preparo e concentração do traçador biológico tiveram início com três fagos: os colifagos 30 e T134 isolados de ambiente aquático por VAL (1997) e a cepa selvagem do colifago T4 gentilmente cedida pelo Prof. Carlos Menck do Instituto de Ciências Biomédicas da USP. O colifago T4 foi aquele que melhor se adequou às exigências acima mencionadas, sendo obtido em maiores concentrações e mantendo-se estável por um maior tempo.

O traçador biológico selecionado para os estudos seguintes foi o colifago T4. 


\subsubsection{Protocolos, meios de cultura, solução tampão}

Os protocolos de manipulação do T4 incluíram a produção e estocagem do hospedeiro. As culturas puras foram usadas em meios líquidos ou semi-sólidos (ágar), ricos em aminoácidos, vitaminas, sais e glicose, para que todas as etapas bioquímicas necessárias para a produção do T4 fossem efetuadas com sucesso, produzindo uma alta concentração do traçador biológico (CARLSON \& MILLER, 1994a).

Os meios de cultura para produção e estocagem das bactérias foram o caldo de soja e triptona (TSB) e o meio de ácido de casamino e glicerol (GCA) que, de acordo com CARLSON \& MILLER (op. cit.), é o meio mais adequado para obter altas concentrações do T4. O meio semi-sólido utilizado para contagem dos colifagos em placa foi o ágar de soja e triptona (TSA) modificado de acordo com AMERICAN PUBLIC HEALTH ASSOCIATION - APHA (1995). A solução de Tris-HCl e NaCl (TSG), mostrada em CARLSON \& MILLER (op. cit.), foi utilizada como meio de diluição e tampão em todos os experimentos.

Os equipamentos necessários para a manipulação do T4 não diferem dos materiais comumente encontrados em laboratório, incluindo vidraria, micropipetas, placas de Petri, autoclaves, banhos com termostato, shakers com termostato, incubadoras e centrífugas. Vidraria, pipetas, meios, diluentes, e outros devem ser estéreis.

\subsubsection{Titulação}

A contagem dos colifagos T4 foi obtida a partir de suspensões dos mesmos que foram diluídas sucessivamente até obter a contagem em placas de Petri. A $1 \mathrm{~mL}$ de cada diluição (meio diluente: TSG), foram acrescentados $2 \mathrm{~mL}$ da cepa hospedeira e 5,5 $\mathrm{mL}$ de TSA modificado, fundido. A mistura foi levemente homogeneizada e disposta em placas de Petri, como mostra a Figura 5.2. Após a solidificação do ágar, as placas foram incubadas para crescimento a $37^{\circ} \mathrm{C}$ por 24 horas (CARLSON \& MILLER, 1994b). A contagem das placas de lise foram realizadas e o resultado expresso em unidades formadoras de placa por $\mathrm{mL}$ (UFP/mL) representadas pelos pontos na placa de lise da Figura 5.3. 


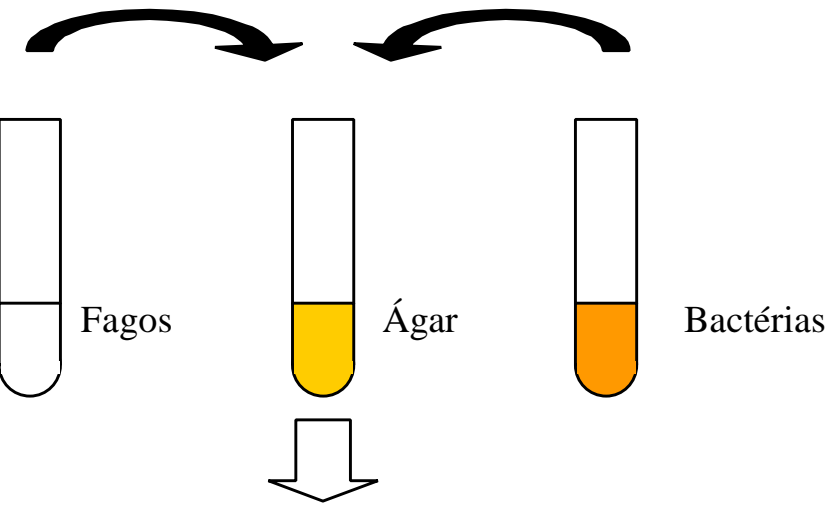

Colocar a mistura em placa de Petri
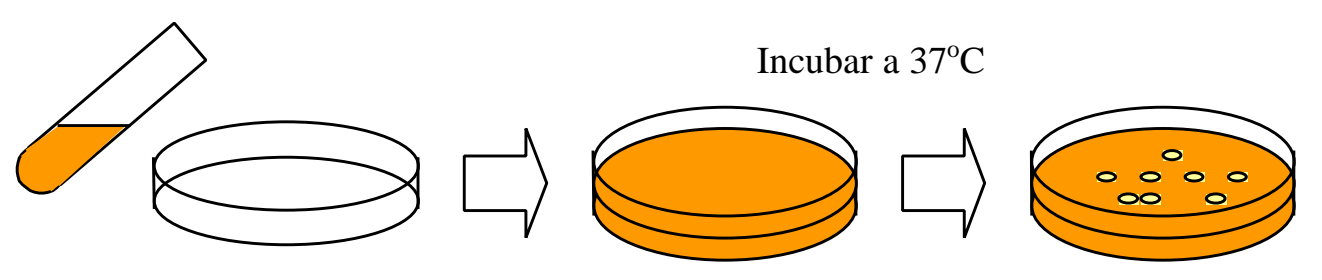

Contar após 24 h em UFP/mL

Figura 5.2 Esquema de titulação

Fonte: Adaptado de MADIGAN et al. (1997).

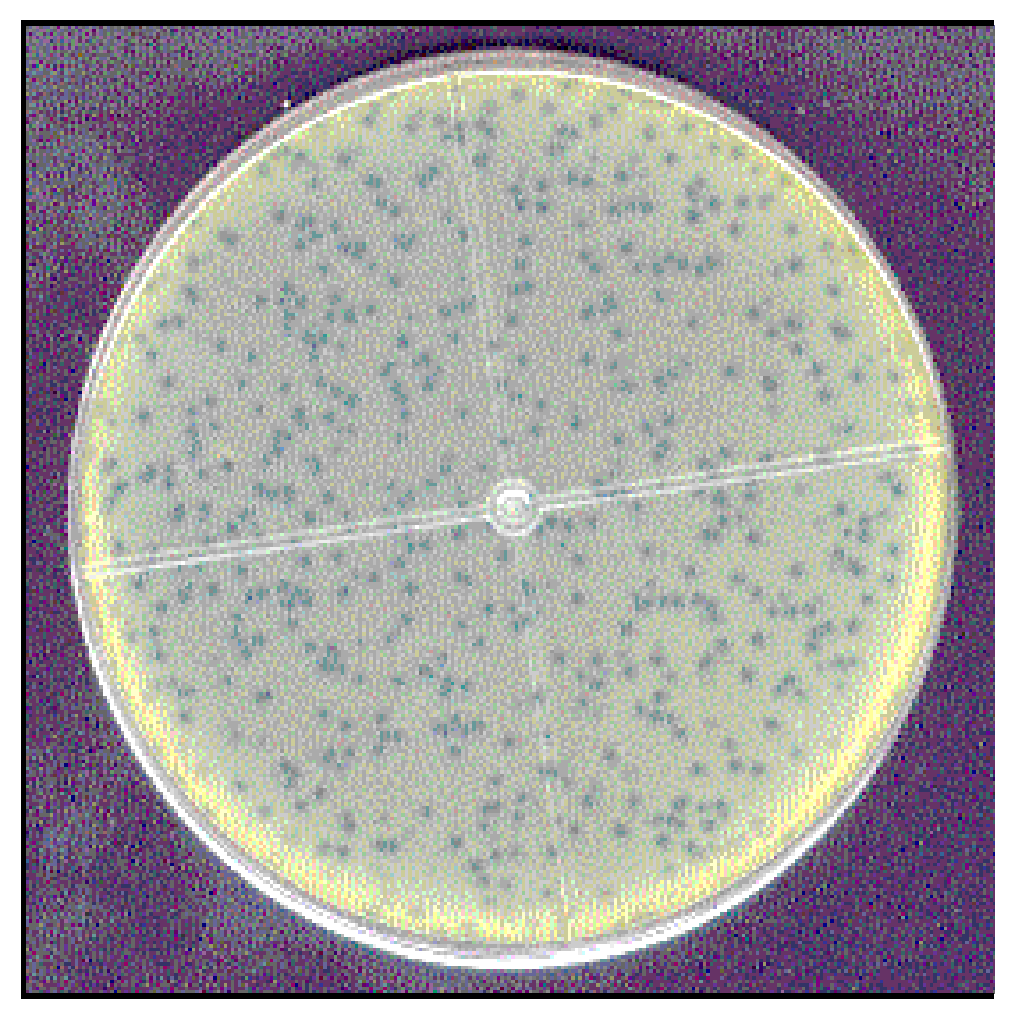

Figura 5.3 Placa de Petri com as unidades formadoras de placa do T4 


\subsubsection{Cultura bacteriana}

Para a estocagem das bactérias utilizou-se o TSB (com 10\% de glicerol), aonde foi inoculada a Escherichia coli $\mathrm{B}$. As bactérias foram incubadas a $37^{\circ} \mathrm{C}$, sob aeração, até obter uma densidade óptica de 0,6 a $490 \mathrm{~nm}$ (equivalente a $3 \times 10^{8}$ células $/ \mathrm{mL}$ ). A densidade óptica foi medida através de um espectrofotômetro previamente calibrado. Em seguida, a suspensão bacteriana foi transferida para tubos e estocada a $-20^{\circ} \mathrm{C}$ (CARLSON \& MILLER, 1994a).

\subsubsection{Preparo do traçador}

Os colifagos T4 multiplicam-se melhor em células de Escherichia coli B, quando infectadas na fase de crescimento exponencial destas. O número de partículas viróticas acrescentadas por célula bacteriana (multiplicidade de infecção) deve ser entre 3 e 15, para obter uma boa concentração de colifagos (CARLSON \& MILLER, op. cit.). É fundamental obter uma alta concentração do traçador para que este seja detectado em amostras, permitindo diluições de diversas ordens de magnitude. Em geral, os fagos podem ser concentrados até $10^{13}-10^{14}$ UFP/mL (MCKAY et al., 1993).

A cepa hospedeira (E. coli B), previamente estocada, foi de novo inoculada em TSB (algumas vezes em GCA) e deixou-se crescer por 3 horas, a $37^{\circ} \mathrm{C}$, ou até atingir a densidade ótica desejada (anteriormente citada). Neste instante, as bactérias passaram por um estímulo térmico de 8 min a $45^{\circ} \mathrm{C}$ para provocar um aumento na produção dos colifagos (WIBERG, 1994). Em seguida, os fagos T4 foram acrescentados à solução.

As células infectadas foram incubadas por um período de 6 a 8 horas em ambiente aerado (shaker), pois consomem bastante oxigênio (KUTTER et al., 1994). Depois, algumas gotas de clorofórmio foram adicionadas, a fim de destruir completamente as células restantes e liberar os fagos eventualmente presos no seu interior (CARLSON \& MILLER, 1994a). Após quinze minutos, a solução foi centrifugada, para que os restos celulares sedimentassem no fundo dos tubos. O sobrenadante foi filtrado em membrana e ultracentrifugado por duas horas. Finalmente, os fagos foram suspensos de novo em meio tampão (TSG). A solução foi titulada e estocada a $4^{\circ} \mathrm{C}$. 


\subsubsection{Inativação do traçador}

Os testes para determinação da inativação dos colifagos foram realizados em temperatura ambiente e pHs de soluções semelhantes aos observados na coluna de solo do cemitério de Vila Nova Cachoeirinha.

Uma alíquota de $18 \mathrm{~mL}$ do efluente da coluna foi disposta em um erlenmeyer de $125 \mathrm{~mL}$ e esterilizada por $15 \mathrm{~min}$ a $120^{\circ} \mathrm{C}$. Depois de esfriada, foram adicionados $2 \mathrm{~mL}$ de uma solução contendo o T4 com uma concentração conhecida. A solução foi homogeneizada e deixada em repouso à temperatura ambiente de $25^{\circ} \mathrm{C}$. Os testes de sobrevivência constaram basicamente em observar a inativação do colifago T4 em solução, ao longo do tempo, através de coletas de amostras, análises e titulações sucessivas. Os experimentos foram realizados em duplicata e as amostras tituladas em triplicatas.

A inativação do colifago T4 foi aproximada pela função exponencial proposta por MERKLI (1975) apud PEKDEGER \& MATTHES (1983):

$$
C=C_{0} e^{-\lambda t}
$$

onde,

$C=$ concentração dos vírus em solução no tempo $t\left[\mathrm{ML}^{-3}\right]$;

$C_{0}=$ concentração inicial $\left[\mathrm{ML}^{-3}\right]$;

$\lambda=$ constante de inativação $\left[\mathrm{T}^{-1}\right]$ dada por $\frac{(\ln 2)}{\tau_{1 / 2}}$, onde $\tau_{1 / 2}$ é a meia-vida do organismo.

\subsubsection{Adsorção do traçador}

A adsorção do T4 nas partículas de solo foi simulada in vitro adicionando $13,5 \mathrm{~mL}$ do efluente da coluna às amostras de $15 \mathrm{~g}$ do solo permeável seco. $\mathrm{O}$ conjunto foi colocado em tubos de centrífuga de $50 \mathrm{~mL}$ e autoclavado por $15 \mathrm{~min}$ a $120^{\circ} \mathrm{C}$. Após o resfriamento, uma alíquota de $1,5 \mathrm{~mL}$ com uma concentração conhecida do colifago T4 $\left(C_{0}\right)$ foi inoculada em cada tubo. Os tubos foram mantidos sob agitação em shaker horizontal por 90 min à temperatura 
ambiente de $25^{\circ} \mathrm{C}$. Em seguida foram centrifugados por 15 min com uma força centrífuga relativa de $1600 \mathrm{~g}$. O mesmo procedimento foi utilizado com o solo do cemitério, mudando o volume do efluente para $27 \mathrm{~mL}$ e a alíquota do colifago T4 para $3 \mathrm{~mL}$. O sobrenadante foi analisado (titulação em triplicatas) para a presença de colifagos remanescentes em suspensão $C$ (DREWRY \& ELIASSEN, 1968). A quantidade de fagos adsorvidos $C^{*}\left[\mathrm{MM}^{-1}\right]$ foi determinada através da relação (FETTER, 1994):

$$
C^{*}=\left(C-C_{0}\right) \frac{\text { Volume da solução }}{\text { peso da amostra }}
$$

A isoterma de adsorção linear foi ajustada aos dados observados da quantidade adsorvida $C^{*}$ em função da concentração em equilíbrio $C$, por mínimos quadrados. A isoterma assume que a quantidade adsorvida é diretamente proporcional à concentração em equilíbrio:

$$
C^{*}=K_{d} C
$$

onde $K_{d}$ é o coeficiente de partição ou distribuição $\left[\mathrm{L}^{3} \mathrm{M}^{-1}\right]$.

\subsubsection{Injeção do traçador}

Depois de atingida a estabilidade desejada (saturação e vazão constante), traçadores químico e biológico foram injetados na coluna em $x=0$ e $t=0$ (Figura 5.4).

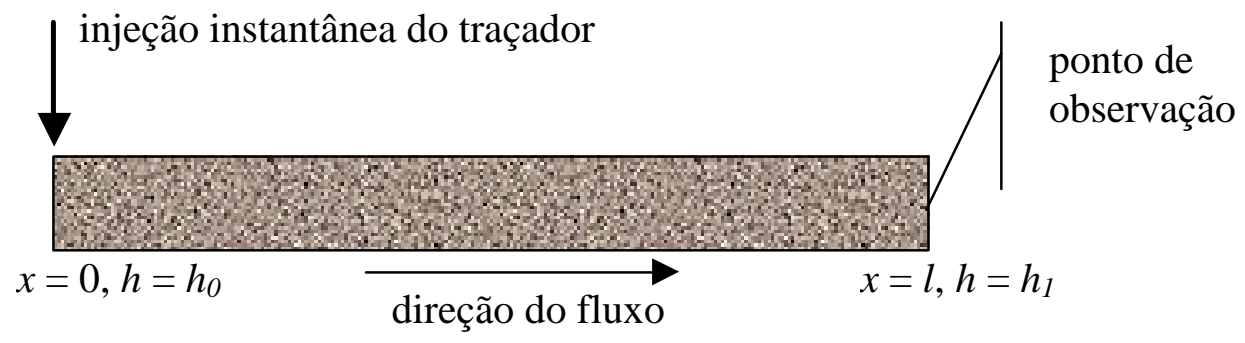

Figura 5.4 Esquema de injeção dos traçadores 
A carga hidráulica $h$ ao longo da coluna foi determinada através da equação de Darcy e através da solução numérica, por diferenças finitas, da equação de fluxo em meio homogêneo e isotrópico, em regime estacionário (equação de Laplace), em uma dimensão:

$$
\frac{\partial^{2} h}{\partial x^{2}}=0
$$

Antes da injeção do traçador biológico, uma solução de cloreto foi injetada na coluna. O fluxo do traçador químico foi monitorado por um condutivímetro instalado na saída da coluna e medida a condutividade elétrica $(\mu \mathrm{S} / \mathrm{cm})$ em intervalos regulares. Supondo que o traçador químico conservativo é transportado na mesma velocidade do efluente, a velocidade linear média $v$ foi determinada por:

$$
v=\frac{x}{t_{\max }}
$$

Como as observações foram feitas na saída da coluna, $x$ é o comprimento da coluna de solo $l$, e $t_{\max }$ é o tempo correspondente à concentração máxima observada (tempo de trânsito). Em seguida, a porosidade efetiva $n_{e}$ do meio foi calculada através de:

$$
v=\frac{q}{n_{e}}=\frac{Q}{n_{e} A}
$$

A dispersividade $\alpha[\mathrm{L}]$ foi determinada a partir da solução numérica (ZHENG, 1992) da equação de dispersão-advecção, a qual em uma dimensão para meio homogêneo e isotrópico é dada por:

$$
D \frac{\partial^{2} C}{\partial x^{2}}-v \frac{\partial C}{\partial x}=\frac{\partial C}{\partial t}
$$

onde $D$ é a dispersão hidrodinâmica longitudinal $D\left[\mathrm{~L}^{2} \mathrm{~T}^{-1}\right]$ definida como:

$$
D=\alpha v+D^{*}
$$


onde $D^{*}$ é o coeficiente de difusão efetivo $\left[\mathrm{L}^{2} \mathrm{~T}^{-1}\right]$.

Após algumas horas da injeção do traçador químico, uma concentração conhecida do colifago T4 em meio inócuo foi injetada na coluna. O transporte do traçador biológico foi observado através da coleta regular de alíquotas de $5 \mathrm{~mL}$ do efluente da coluna, seguida de análise das amostras para a presença do colifago T4 e sua titulação.

A equação de dispersão-advecção foi ajustada aos dados observados de concentração do colifago T4 na saída da coluna, mas desta vez considerando os efeitos de inativação e retardamento provocado pela adsorção dos fagos nos solos:

$$
D \frac{\partial^{2} C}{\partial x^{2}}-v \frac{\partial C}{\partial x}-\frac{\rho}{n_{e}} \frac{\partial C^{*}}{\partial t}-\lambda C=\frac{\partial C}{\partial t}
$$

onde $\rho$ é a massa específica da coluna de solo $\left[\mathrm{ML}^{-3}\right]$.

A ferramenta utilizada para a solução numérica das equações foi o pacote de softwares chamado Visual MODFLOW da WATERLOO HYDROGEOLOGIC (1998). 


\subsection{Etapa de campo}

O conjunto de operações de campo visou caracterizar o aqüífero freático, incluindo geometria, parâmetros hidrodinâmicos, qualidade das águas e estudar o transporte e a retenção do contaminante no cemitério de Vila Nova Cachoeirinha.

\subsubsection{Técnicas geofísicas de investigação}

Sondagens elétricas verticais (SEVs) e caminhamentos eletromagnéticos (EMs) foram utilizados para obter informações sobre o subsolo do cemitério. As duas técnicas são baseadas nas propriedades elétricas das rochas e dos minerais (a condutividade elétrica ou o seu inverso, a resistividade elétrica).

As SEVs fornecem informação sobre a variação em profundidade da resistividade aparente, medindo-se a diferença de potencial elétrico entre eletrodos, quando se faz circular no solo uma corrente elétrica contínua. Essa técnica permite avaliações na natureza e estrutura do subsolo, porque, em geral, as rochas sãs apresentam uma resistividade muito maior que as rochas alteradas; a presença de água nos poros e nas fissuras diminui a resistividade do meio. Assim como a proporção de argila existente também influi nesse valor.

Oito SEVs foram realizadas para obter as profundidades aproximadas do topo da camada saturada e do embasamento cristalino. O Quadro 5.1 detalha data, localização e cota das SEVs e a Figura 5.5 mostra a sua localização na área de estudo.

Quadro 5.1. Data, localização e cota das sondagens elétricas verticais

\begin{tabular}{|lcccc|}
\hline $\begin{array}{c}\text { Sondagem } \\
\text { Elétrica }\end{array}$ & Data & $\begin{array}{c}\mathbf{x} \\
\text { (UTM) }\end{array}$ & $\begin{array}{c}\mathbf{y} \\
\text { (UTM) }\end{array}$ & $\begin{array}{c}\mathbf{z} \\
(\mathbf{m})\end{array}$ \\
\hline SEV-1 & $03 / 05 / 98$ & 329.760 & 7.402 .545 & 780 \\
SEV-2 & $03 / 05 / 98$ & 329.833 & 7.402 .528 & 772 \\
SEV-3 & $04 / 06 / 98$ & 329.801 & 7.402 .535 & 775 \\
SEV-4 & $04 / 06 / 98$ & 329.867 & 7.402 .522 & 761 \\
SEV-5 & $09 / 06 / 98$ & 329.665 & 7.402 .609 & 776 \\
SEV-6 & $09 / 06 / 98$ & 329.525 & 7.402 .575 & 763 \\
SEV-7 & $10 / 07 / 98$ & 329.456 & 7.402 .559 & 756 \\
SEV-8 & $10 / 07 / 98$ & 329.350 & 7.402 .544 & 748 \\
\hline
\end{tabular}




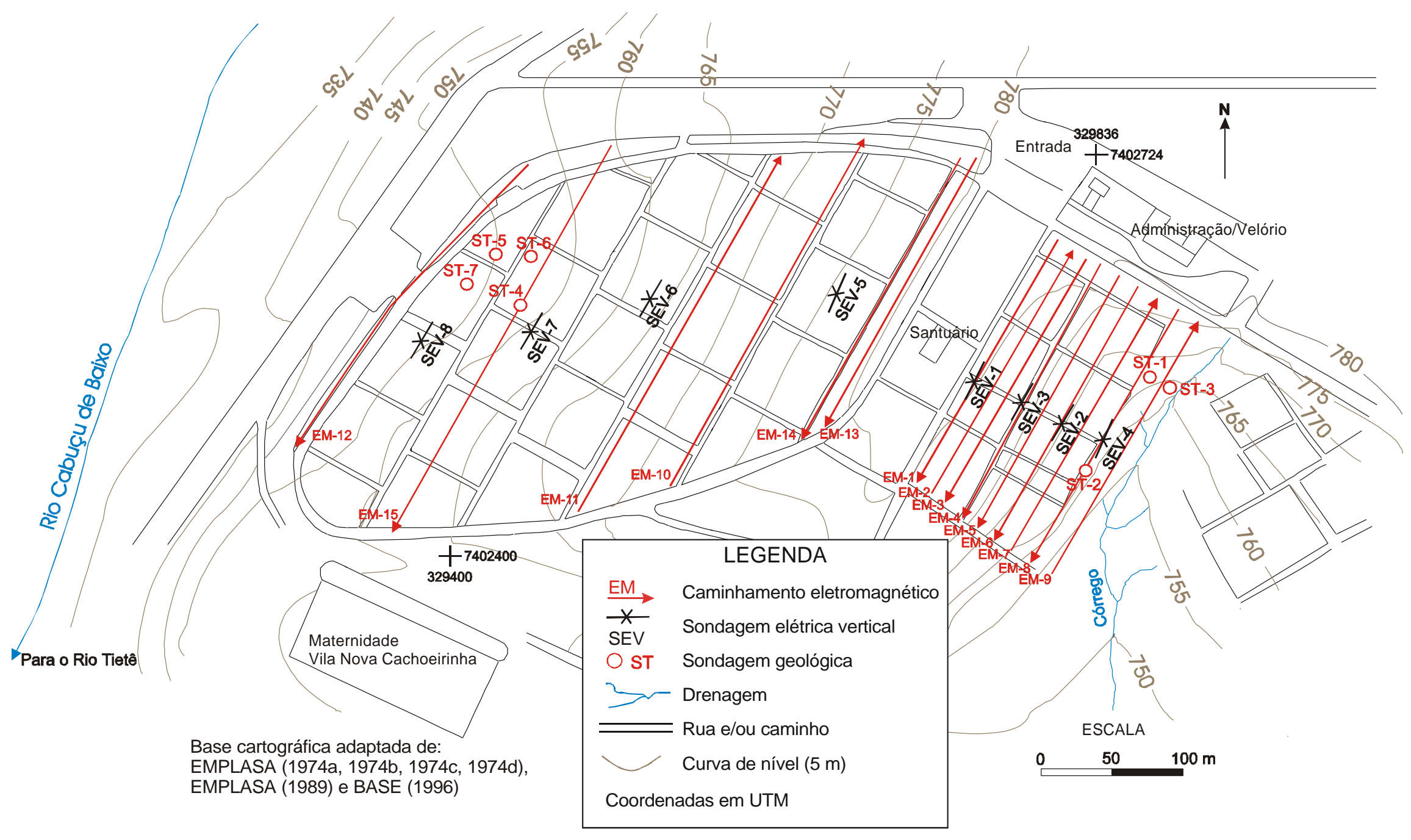

Figura 5.5 Localização das sondagens elétricas, caminhamentos eletromagnéticos e sondagens geológicas 
A configuração dos eletrodos foi a de Schlumberger, com abertura máxima entre os eletrodos de corrente de $320 \mathrm{~m}$. O equipamento utilizado foi um transmissor de corrente contínua (Marca Tectrol, Modelo: TDC 1000/12, P=500 W), um receptor (milivoltímetro com precisão de 0,2 $\mathrm{mV}$ ), eletrodos de corrente e de potencial, e fios. Um modelo de camadas geoelétricas foi ajustado aos dados de campo para cada sondagem.

O método eletromagnético consiste na propagação de campos eletromagnéticos através e acima do subsolo. A resposta de um corpo condutor no subsolo à propagação de um campo eletromagnético primário é a geração de um campo eletromagnético secundário. O campo resultante é medido em uma bobina receptora (KEAREY \& BROOKS, 1984). Este método permite estudar a variação lateral na condutividade elétrica do subsolo.

Quinze EMs foram executados no cemitério (Ver Figura 5.5), para identificar anomalias de condutividade elétrica e associá-las à presença de contaminação no subsolo, totalizando 3.490 $\mathrm{m}$ de percurso. A distância entre o receptor e o transmissor foi fixada em $10 \mathrm{~m}$, garantindo uma profundidade de penetração de aproximadamente $15 \mathrm{~m}$ com o campo eletromagnético vertical à superfície, e de 7,5 m com o campo horizontal à superfície. Os locais que apresentaram maior condutividade elétrica foram escolhidos para a realização das sondagens geológicas, instalação dos poços de monitoração e coleta de amostras. Utilizou-se o equipamento EM 34-3 da Geonics, com bobinas transmissora e receptora. O Quadro 5.2 mostra data e comprimento dos EMs.

Quadro 5.2 Datas e comprimentos dos caminhamentos eletromagnéticos

\begin{tabular}{|ccc|}
\hline Caminhamento eletromagnético & Data & Tamanho $(\mathbf{m})$ \\
\hline EM-1 & $10 / 03 / 98$ & 190 \\
EM-2 & $10 / 03 / 98$ & 210 \\
EM-3 & $10 / 03 / 98$ & 210 \\
EM-4 & $11 / 03 / 98$ & 210 \\
EM-5 & $11 / 03 / 98$ & 200 \\
EM-6 & $12 / 03 / 98$ & 210 \\
EM-7 & $12 / 03 / 98$ & 230 \\
EM-8 & $12 / 03 / 98$ & 210 \\
EM-9 & $12 / 03 / 98$ & 220 \\
EM-10 & $02 / 04 / 98$ & 220 \\
EM-11 & $02 / 04 / 98$ & 300 \\
EM-12 & $02 / 04 / 98$ & 300 \\
EM-13 & $16 / 04 / 98$ & 180 \\
EM-14 & $16 / 04 / 98$ & 300 \\
EM-15 & $16 / 04 / 98$ & 300 \\
\hline
\end{tabular}




\subsubsection{Sondagem geológica}

Sete sondagens a trado foram executadas no cemitério para a investigação das características do solo, seguindo as recomendações da ASSOCIAÇÃO BRASILEIRA DE GEOLOGIA DE ENGENHARIA - ABGE (1990). A Figura 5.5 indica a localização e o Quadro 5.3 mostra as datas, coordenadas, cotas, profundidades e amostras coletadas das sondagens. As ferramentas utilizadas foram trado manual de 3", cruzetas, hastes e luvas de ferro galvanizado, ponteiras, chaves de grifo, trena, sacos plásticos e medidor de nível d'água.

Quadro 5.3 Datas, coordenadas e cotas das sondagens geológicas

\begin{tabular}{|ccccccr|}
\hline $\begin{array}{c}\text { Sondagem } \\
\text { geológica }\end{array}$ & Data & $\begin{array}{c}\mathbf{x} \\
(\mathbf{U T M})\end{array}$ & $\begin{array}{c}\mathbf{y} \\
(\mathbf{U T M})\end{array}$ & $\begin{array}{c}\mathbf{z} \\
(\mathbf{m})\end{array}$ & $\begin{array}{c}\text { Profundidade } \\
(\mathbf{m})\end{array}$ & Amostra coletada \\
\hline ST-1 & $09 / 05 / 98$ & 329.886 & 7.402 .577 & 766,8 & 2,45 & ST-1/0, ST-1/80, ST-1/140 \\
ST-2 & $09 / 05 / 98$ & 329.864 & 7.402 .532 & 765,2 & 1,92 & ST-2/0, ST-2/80, ST-2/140 \\
ST-3 & $09 / 05 / 98$ & 329.888 & 7.402 .576 & 766,5 & 0,8 & ST-3/0, ST-3/80 \\
ST-4 & $17 / 05 / 98$ & 329.445 & 7.402 .584 & 752,7 & 2,9 & ST-4/0, ST-4/80, ST-4/140 \\
ST-5 & $17 / 05 / 98$ & 329.428 & 7.402 .617 & 750,0 & 2,9 & ST-5/0, ST-5/80, ST-5/140 \\
ST-6 & $17 / 05 / 98$ & 329.444 & 7.402 .622 & 750,8 & 1,0 & ST-6/0, ST-6/80 \\
ST-7 & $17 / 05 / 98$ & 329.404 & 7.402 .603 & 748,8 & 2,44 & ST-7/0, ST-7/80, ST-7/140 \\
\hline
\end{tabular}

Dezenove amostras de solo foram coletadas em profundidades de 0 a 20 (ST-/0), 80 a 100 (ST-/80), 140 a 160 cm (ST-/140) ou até encontrar o nível de água. As amostras foram acondicionadas em sacos plásticos transparentes de alta resistência e enviadas para análises física e química no Laboratório de Análises de Solo da Escola Superior de Agricultura Luíz de Queiroz (ESALQ) da USP.

O solo foi analisado para determinar a textura, o $\mathrm{pH}$, a quantidade de matéria orgânica, a capacidade de troca de cátions e a presença de $\mathrm{Ca}^{+}, \mathrm{Mg}^{+}, \mathrm{P}$ e $\mathrm{K}^{+}$. A granulometria foi determinada por tamisação e pelo método do densímetro (EMPRESA BRASILEIRA DE PESQUISA AGROPECUÁRIA - EMBRAPA, 1997). A classificação textural foi realizada através do diagrama triangular adotado pela SOCIEDADE BRASILEIRA DE CIÊNCIA DO SOLO apud PREVEDELLO (1996). O potencial foi medido por meio de eletrodo combinado imerso em uma suspensão solo:líquido (água, $\mathrm{KCl}$ e $\mathrm{CaCl}_{2}$ ). $\mathrm{Ca}^{+}, \mathrm{Mg}^{+}, \mathrm{P}$ e $\mathrm{K}^{+}$foram extraídos das amostras através de resinas de troca iônica. A determinação de $\mathrm{P}$ foi realizada por colorimetria, a de $\mathrm{Ca}^{+2}$ e $\mathrm{Mg}^{+2}$ por espectrofotometria de absorção atômica e a de $\mathrm{K}^{+}$por 
fotômetro de chama. A quantidade de matéria orgânica presente na amostra foi calculada pelo método de Walkley-Black (EMBRAPA, 1997). A capacidade de troca de cátions foi obtida a partir da soma total dos cátions que o solo pode reter na superfície coloidal (EMBRAPA, op. cit.).

\subsubsection{Poços de monitoração}

Vinte poços de monitoração foram construídos no cemitério de Vila Nova Cachoeirinha, de acordo com a norma NBR 13.895 da ASSOCIAÇÃO BRASILEIRA DE NORMAS TÉCNICAS - ABNT (1997), entre dezembro de 1998 e agosto de 1999, para monitorar a carga hidráulica do aqüífero livre, a qualidade da água subterrânea e a realização de testes de traçador.

A localização dos poços (Figura 5.6) foi definida através dos estudos eletromagnéticos já citados. As áreas que apresentaram maiores valores de condutividade elétrica foram escolhidas para a instalação dos poços. Três dos vinte poços foram construídos para servirem como valores de fundo, sendo localizados em áreas a montante das sepulturas (P11) ou com o nível d'água profundo (P6 e P8). Como o teste preliminar tipo slug, realizado no furo de sondagem ST-1 em 24/05/98, mostrara uma baixa condutividade hidráulica (1,07E-6 m/s) e as sondagens geológicas indicaram alto teor de argila, alguns poços (P1 a P4; P12 a P20) foram espaçados de 0,5 a 3 m para a aplicação dos testes de traçador. A Figura 5.7 mostra, em detalhes, a localização dos poços usados nos testes de traçador.

Os furos para instalação dos poços foram executados com trado manual de 4" de diâmetro. O revestimento interno é de tubos de PVC de 2" de diâmetro. O filtro é formado por ranhuras horizontais de 2 a $3 \mathrm{~mm}$ de espessura, espaçadas de $1 \mathrm{~cm}$. Uma tela de náilon envolve a porção ranhurada do tubo. O espaço anelar, entre o tubo e o furo, foi preenchido com quartzo moído até cobrir as ranhuras, servindo como pré-filtro. Na porção acima do pré-filtro, foi colocada bentonita, e acima desta, o solo retirado do furo. Em volta da boca do poço, uma laje de concreto de aproximadamente $40 \mathrm{~cm}$ funciona como selo sanitário. Acima deste foi colocado um tubo de proteção de ferro, com uma tampa na parte superior, fechada a cadeado para evitar a penetração de elementos estranhos. Os poços foram esgotados após a construção. 


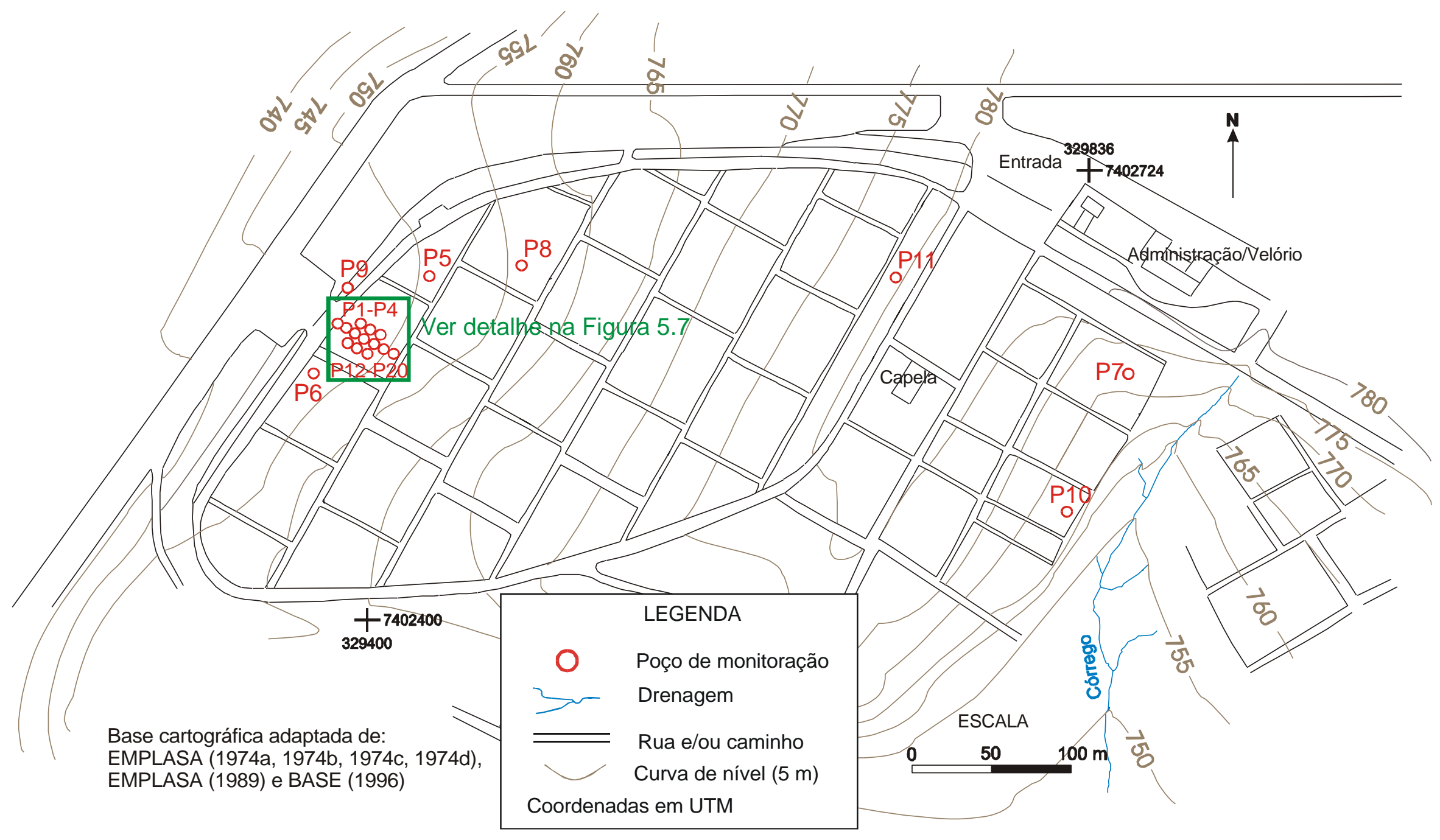

Figura 5.6 Mapa de localização dos poços de monitoração 


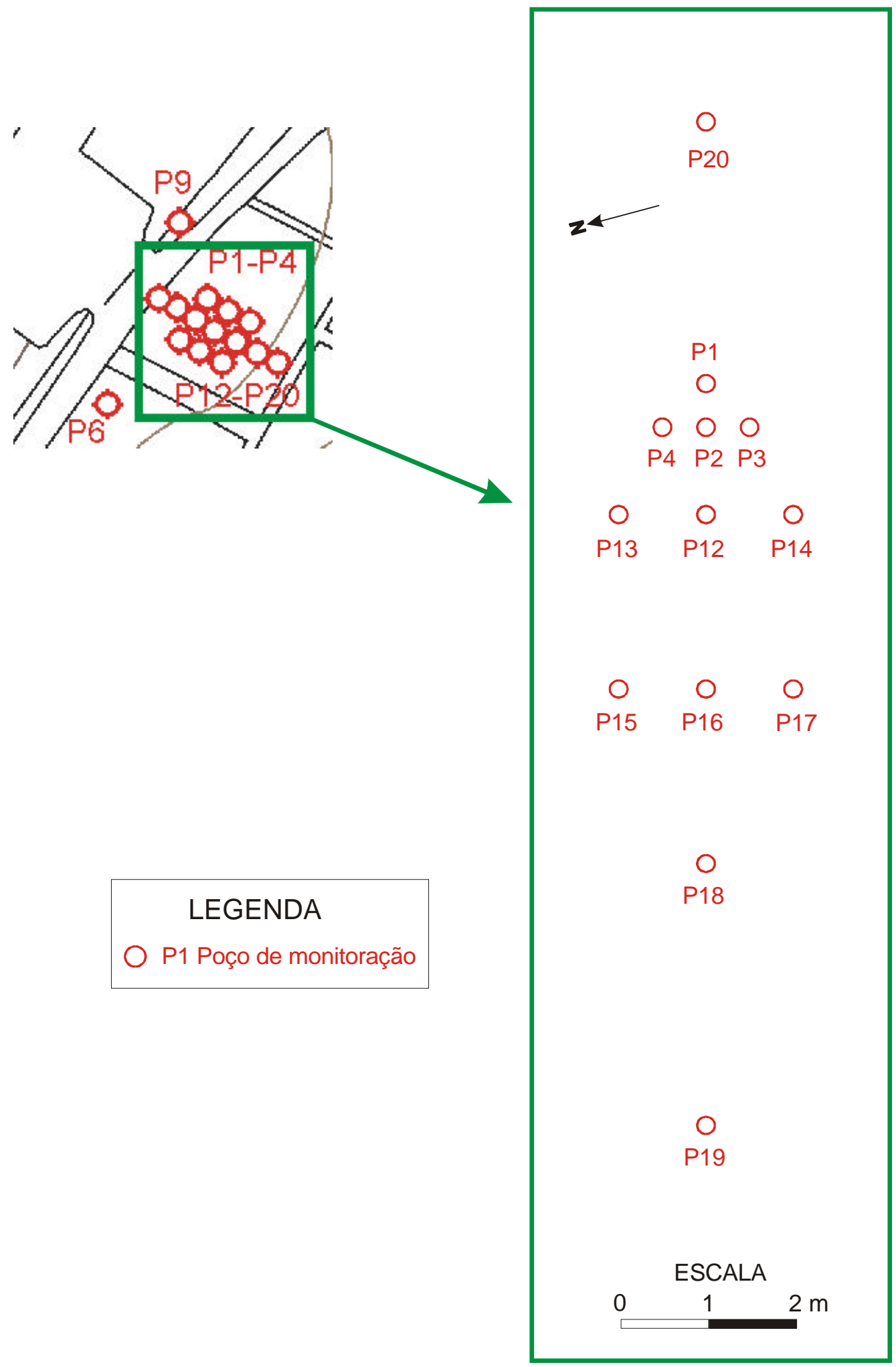

Figura 5.7 Mapa de detalhe dos poços de monitoração empregados no teste de traçador 
Os equipamentos utilizados foram o trado manual de 4", cruzetas, hastes e luvas de ferro galvanizado, ponteira, chaves de grifo, barras de $6 \mathrm{~m}$ de PVC branco de 2", luvas e caps plásticos de $60 \mathrm{~mm}$, quartzo moído, bentonita PA 25, tela e linha de náilon, cimento, areia, brita, água, tubo de ferro, zarcão, cadeado, serra, trena, amostrador, corda, balde e medidor de nível d'água. A Figura 5.8 mostra um esquema construtivo dos poços de monitoração.

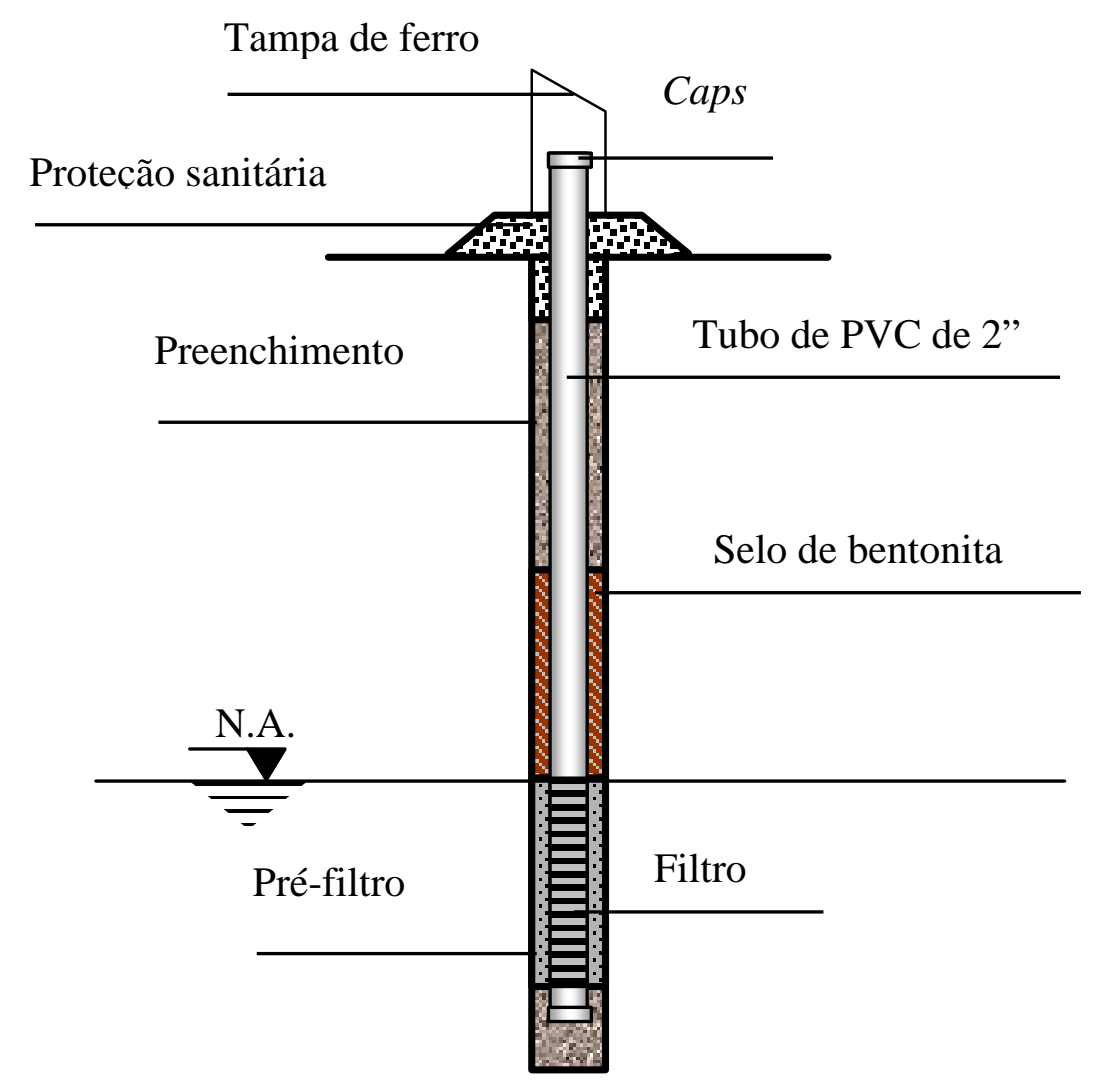

Figura 5.8 Esquema construtivo dos poços de monitoração

Os poços foram construídos para que atingissem a profundidade de $1 \mathrm{~m}$ abaixo do nível freático. As cotas dos poços foram determinadas a partir do levantamento aerofotogramétrico realizado pela EMPRESA DE PLANEJAMENTO DA GRANDE SÃO PAULO - EMPLASA (1974a, 1974b, 1974c, 1974d), pelo nivelamento geométrico realizado em campo e por rastreamento por satélites através de instrumentos de GPS. Os poços P1, P5 a P10 e P18 possuem filtros de 1,00 m. Os poços P2 a P4 e P12 a P17 - a jusante do poço injetor (P1) - foram construídos com filtros de $0,50 \mathrm{~m}$ para evitar diluições das amostras nos testes de traçador. Os poços P11, P19 e P20 possuem filtros maiores $(2,00,3,00$ e 2,24 m, respectivamente) para a 
monitoração do nível freático com maior segurança. O Quadro 5.4 destaca a localização e características construtivas dos poços instalados.

Durante a construção e operação dos poços foram registradas dificuldades, como: a violação de alguns poços, com a ruptura dos cadeados e danificação das proteções de ferro; o nível d'água no poço P11 permaneceu abaixo do filtro durante a maior parte da amostragem; o acúmulo de argila nos filtros, imediatamente após a construção, obstruiu permanentemente os poços P14 e P18.

Quadro 5.4 Localização e características construtivas dos poços de monitoração.

\begin{tabular}{|lrrrcrr|}
\hline Poço & $\begin{array}{c}\text { Data da } \\
\text { construção }\end{array}$ & \multicolumn{1}{c}{$\mathbf{c}$ (UTM) } & \multicolumn{1}{c}{$\begin{array}{c}\text { y } \\
\text { UTM) }\end{array}$} & \multicolumn{1}{c}{$\begin{array}{c}\text { (m) } \\
\text { Profundidade }\end{array}$} & $\begin{array}{c}\text { Filtro } \\
(\mathbf{m})\end{array}$ \\
\hline P1 & $01 / 12 / 98$ & $329.393,7$ & $7.402 .592,4$ & 747,430 & 4,90 & 1,0 \\
P2 & $01 / 12 / 98$ & $329.393,2$ & $7.402 .592,6$ & 747,408 & 4,84 & 0,5 \\
P3 & $01 / 12 / 98$ & $329.393,0$ & $7.402 .592,1$ & 747,413 & 4,84 & 0,5 \\
P4 & $02 / 12 / 98$ & $329.393,4$ & $7.402 .593,0$ & 747,412 & 4,84 & 0,5 \\
P5 & $22 / 06 / 99$ & 329.418 & 7.402 .634 & 748,802 & 5,43 & 1,0 \\
P6 & $23 / 06 / 99$ & 329.358 & 7.402 .603 & 747,509 & 7,60 & 1,0 \\
P7 & $24 / 06 / 99$ & 329.892 & 7.402 .596 & 767,529 & 6,20 & 1,0 \\
P8 & $25 / 06 / 99$ & 329.480 & 7.402 .634 & 753,017 & 7,80 & 1,0 \\
P9 & $29 / 06 / 99$ & 329.377 & 7.402 .615 & 745,843 & 7,84 & 1,0 \\
P10 & $30 / 06 / 99$ & 329.863 & 7.402 .535 & 765,364 & 5,30 & 1,0 \\
P11 & $06 / 07 / 99$ & 329.727 & 7.402 .651 & 779,695 & 17,15 & 2,0 \\
P12 & $06 / 07 / 99$ & $329.392,3$ & $7.402 .593,4$ & 747,366 & 5,00 & 0,5 \\
P13 & $07 / 07 / 99$ & $329.392,7$ & $7.402 .593,9$ & 747,375 & 4,84 & 0,5 \\
P14 & $13 / 07 / 99$ & $329.391,9$ & $7.402 .592,1$ & 747,377 & 4,84 & 0,5 \\
P15 & $13 / 07 / 99$ & $329.390,9$ & $7.402 .594,8$ & 747,304 & 4,84 & 0,5 \\
P16 & $14 / 07 / 99$ & $329.390,5$ & $7.402 .593,9$ & 747,281 & 4,84 & 0,5 \\
P17 & $14 / 07 / 99$ & $329.390,1$ & $7.402 .593,0$ & 747,263 & 4,84 & 0,5 \\
P18 & $15 / 07 / 99$ & $329.388,7$ & $7.402 .594,7$ & 747,135 & 4,84 & 1,0 \\
P19 & $23 / 07 / 99$ & 329.386 & 7.402 .596 & 746,891 & 6,00 & 3,0 \\
P20 & $23 / 07 / 99$ & $329.396,4$ & $7.402591,1$ & 747,590 & 7,50 & 2,24 \\
\hline
\end{tabular}

As amostras de solo coletadas durante a construção dos vinte poços de monitoração foram levadas para o Laboratório de Sedimentologia do Instituto de Geociências da USP para análise textural e preparação de lâminas da fração de argila para identificação de minerais. A granulometria foi determinada por tamisação e pipetagem (EMBRAPA, 1997). As frações de argila foram dispostas em lâminas de vidro para análise mineralógica realizada pelo Laboratório de Difratometria de Raios X do Instituto de Geociências da USP. As frações de argila das amostras, cujas análises mineralógicas não foram conclusivas, foram submetidas à análise 
química total realizada no Laboratório de Fluorescência de Raios X do Instituto de Geociências da USP, onde foram determinados $\mathrm{SiO}_{2}, \mathrm{Al}_{2} \mathrm{O}_{3}, \mathrm{MnO}, \mathrm{MgO}, \mathrm{CaO}, \mathrm{Na}_{2} \mathrm{O}, \mathrm{K}_{2} \mathrm{O}, \mathrm{TiO}_{2}, \mathrm{P}_{2} \mathrm{O}_{5}$, $\mathrm{Fe}_{2} \mathrm{O}_{3}$ e perda ao fogo.

\subsubsection{Condutividade hidráulica}

Testes tipo slug foram feitos nos poços de monitoração para determinar a condutividade hidráulica in situ. No teste, uma quantidade conhecida de água é adicionada ou retirada do poço e, imediatamente, o nível d'água é observado ao longo do tempo.

A condutividade hidráulica $K$ foi determinada através da solução analítica proposta por HVORSLEV (1951) apud FETTER (1994) para um poço parcialmente penetrante em um aqüífero livre:

$$
K=\frac{r^{2} \ln (L / R)}{2 L T_{o}}
$$

onde, $r$ é o raio do poço, $L$ é o comprimento do filtro, $R$ é o raio do furo, e $T_{o}$ é o tempo necessário para que o nível do poço suba ou desça de $37 \%$ da variação inicial $h / h_{o}=0,37$.

O procedimento de campo consistiu no seguinte:

1. Medir e registrar o nível estático e a profundidade do poço;

2. Registrar o volume do amostrador;

3. Submergir totalmente o amostrador abaixo do nível estático e esperar de 2 a 5 minutos até atingir as condições de regime permanente;

4. Rapidamente remover o amostrador e registrar o nível de água até que este retornasse às condições iniciais.

O procedimento analítico consistiu de:

1. Tabular dados de campo e calcular a carga hidráulica normalizada $(H-h) /\left(H-H_{o}\right)$ como mostra a Figura 5.9. $H_{0}$ foi estimado a partir do volume do amostrador;

2. Desenhar o gráfico de $(H-h) /\left(H-H_{o}\right)$ em função do tempo em escala semi-log;

3. Ajustar uma reta aos dados em escala semi-log;

4. Determinar $T_{o}$ em $(H-h) /\left(H-H_{o}\right)=0,37$; 
5. Calcular $K$ usando a equação citada anteriormente.

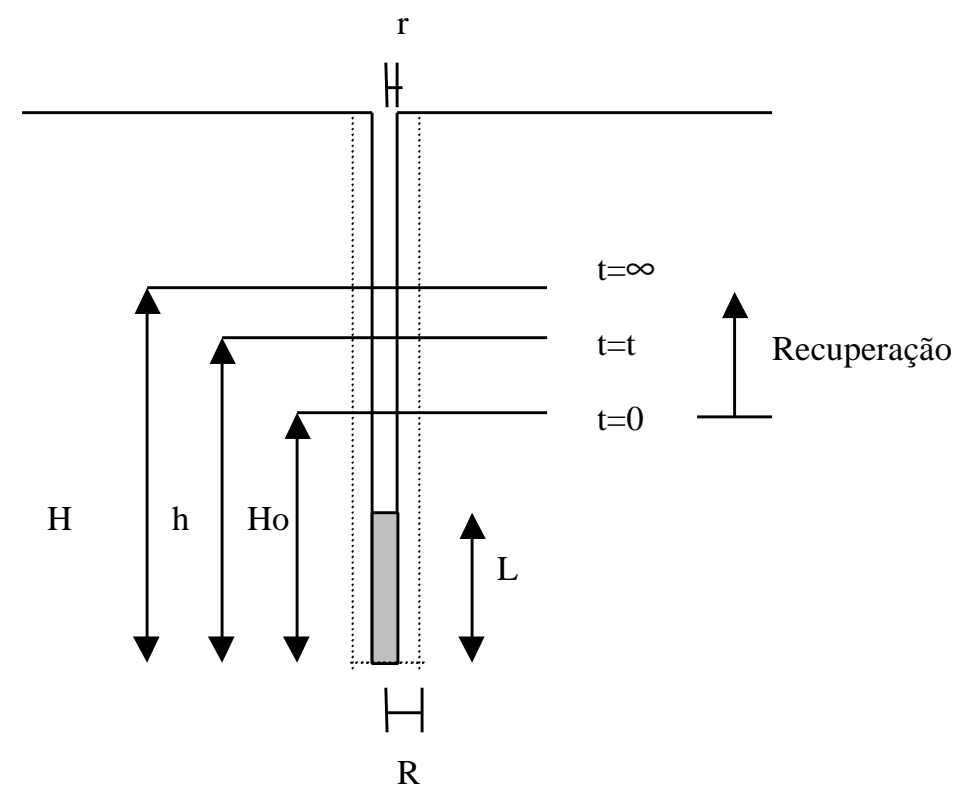

Figura 5.9 Poço de monitoração com os parâmetros do teste slug

O teste assume que o meio é infinito, isotrópico e homogêneo, que a água e o solo são incompressíveis, que a Lei de Darcy pode ser aplicada, que não existem perdas por atrito ou fugas e que as flutuações temporais são mínimas. As principais limitações do teste são sedimentação ou corrosão do filtro, erosão durante o seu desenvolvimento e a presença de bolhas de ar (PERSON, 1991). Como a porção do aqüífero ensaiada é limitada, a condutividade hidráulica determinada no teste é um valor pontual que não deve ser estendido além das proximidades do poço em consideração (FETTER, 1994).

Os equipamentos utilizados foram amostradores, cordas, cronômetro, medidor de nível e trena.

\subsubsection{Testes de traçador}

Uma solução saturada de $\mathrm{NaCl}$ e água destilada (40 L) foi introduzida no aquífero freático através do poço de monitoração P1. As mudanças de condutividade elétrica de amostras de águas subterrâneas foram monitoradas ao longo do tempo no poço injetor e em poços de observação a jusante (P2, P3, P4, P12, P13, P14, P15, P16, P17, P18, P19) a fim de acompanhar o deslocamento da pluma de $\mathrm{NaCl}$. 
Os dados observados foram ajustados a um modelo numérico de fluxo de água subterrânea e de transporte de massa para estimar a dispersividade $\alpha$ de forma semelhante aos trabalhos de injeção do traçador em colunas de solo mostrados anteriormente. A ferramenta utilizada para a solução numérica das equações foi o pacote de softwares chamado Visual MODFLOW da WATERLOO HYDROGEOLOGIC (1998). A área modelada é aquela onde estão concentrados os poços P1 a P4 e P12 a P20. As condições de contorno foram definidas para o aqüífero freático, com cargas hidráulicas especificadas nos poços P20 e P19. Ao poço P1 foi acrescentada a carga hidráulica observada durante a injeção do traçador químico. O modelo foi simulado em uma dimensão, em regime transiente, e calibrado através das observações dos poços de monitoração.

\subsubsection{Amostragem de águas subterrâneas}

Inicialmente, o nível estático do poço a ser amostrado foi medido. Depois, este foi esgotado de três vezes a quantidade correspondente à coluna de água existente no seu interior. Finalmente, as amostras de águas subterrâneas foram coletadas com amostradores de acrílico, previamente lavados e desinfetados em laboratório, presos a uma corda limpa e introduzidos no interior do poço. Boca do poço, amostrador e corda foram desinfetados com etanol (70\%) minutos antes da coleta. Um conjunto amostrador foi utilizado para cada poço.

As amostras foram coletadas e armazenadas segundo CETESB (1988). As amostras foram armazenadas em frascos:

- estéreis de plástico de boca larga (200 mL);

- $\quad$ estéreis de vidro (5 L);

- de polipropileno de baixa densidade de boca larga $(250 \mathrm{~mL})$;

- de polipropileno de baixa densidade de boca larga (125 mL) e congeladas;

- de polipropileno de baixa densidade de boca larga $(125 \mathrm{~mL})$ e preservadas com $\mathrm{HNO}_{3}$;

- de polipropileno de baixa densidade de boca larga $(125 \mathrm{~mL})$ e preservadas com $\mathrm{H}_{2} \mathrm{SO}_{4}$. 
As amostras foram mantidas sob refrigeração e enviadas no prazo de 24 horas para:

- Laboratório de Hidrogeoquímica do Centro de Pesquisas de Águas Subterrâneas do Instituto de Geociências da USP, para análise química;

- Laboratório de Microbiologia Ambiental do Instituto de Ciências Biomédicas da USP, para indicadores biológicos;

- Laboratório de Virologia do Instituto de Ciências Biomédicas da USP, para análise de vírus.

Alguns parâmetros físicos e químicos foram determinados in situ com aparelhos previamente calibrados. Eletrodos foram limpos e imersos nas amostras para medir:

- Temperatura $\left({ }^{\circ} \mathrm{C}\right)$. Equipamento: Condutivímetro, marca WTW, modelo LF 330, resolução: $0,1 \mathrm{~K}$, precisão de $0,5 \%$ do valor medido \pm 1 dígito;

- pH. Equipamento: Medidor de pH/potencial redox, marca WTW, modelo: pH 330, resolução: 0,01, precisão: 0,01 \pm 1 dígito. Modelo do eletrodo: Sentix 41;

- Potencial redox $(\mathrm{mV})$. Equipamento: Medidor de $\mathrm{pH} /$ potencial redox, marca WTW, modelo: pH 330, resolução: $1 \mathrm{mV}$, precisão: $1 \mathrm{mV} \pm 1$ dígito. Modelo do eletrodo: Sentix ORP;

- Condutividade elétrica $(\mu \mathrm{S} / \mathrm{cm})$. Equipamento: Condutivímetro, marca WTW, modelo LF 330, resolução: $1 \mu \mathrm{S} / \mathrm{cm}$, precisão: $\pm 1 \%$ do valor medido \pm 1 dígito, modelo da célula de condutividade: TetraCon 325. Foi utilizada compensação linear para a temperatura de $25^{\circ} \mathrm{C}$;

- Oxigênio dissolvido (mg/L). Equipamento: Oxímetro, marca WTW, modelo: Oxi 330 , resolução $0,01 \mathrm{mg} / \mathrm{L}$, precisão: $\pm 0,5 \%$ do valor medido \pm 1 dígito. Modelo da sonda: CellOx 325, bico de calibração de ar: OxiCal - SL.

A alcalinidade (em mg/L de $\mathrm{HCO}_{3}{ }^{-}$) foi determinada in situ, por titulação alcalinimétrica, de acordo com HYPOLITO (1998).

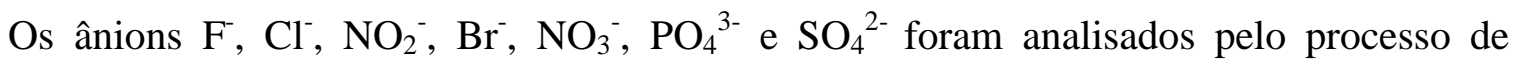
cromatografia líquida no aparelho DIONEX 2010i; os cátions $\mathrm{Na}^{+}$e $\mathrm{K}^{+}$foram analisados pelo processo de fotometria de chama desenvolvido no fotômetro B 262 da Micronal; os cátions $\mathrm{Cu}^{2+}$, 


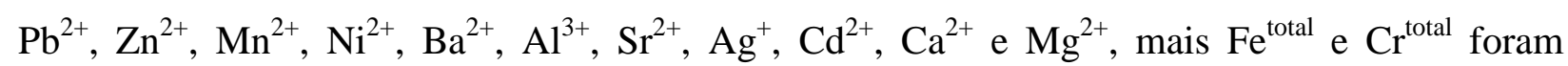
analisados pelo processo de espectrofotometria desenvolvido no aparelho de absorção atômica CG AA7000 BC. Os íons maiores foram transformados em meq/L e os balanços iônicos realizados para as amostras de água dos poços. Foram utilizadas apenas as amostras que satisfizeram o afastamento entre cátions e ânions de até $10 \%$. Os resultados foram transformados em percentagem de meq/L para a confecção do diagrama de Piper e classificação das águas.

As primeiras amostras coletadas foram destinadas à análise microbiológica. Foram analisados os seguintes indicadores:

- Bactérias heterotróficas. O método de detecção das bactérias heterotróficas aeróbias e anaeróbias facultativas usado foi a contagem em placas, onde alíquotas adequadas da amostra são inoculadas em placas de Petri com posterior adição de um meio de cultura apropriado, de acordo com a norma L5.201 da CETESB (1996);

- Coliformes totais e fecais. A determinação dos coliformes totais e fecais foi realizada pela técnica de tubos múltiplos, como recomenda a norma L5.202 da CETESB (1993a);

- Bactérias proteolíticas. Geralmente utilizado na microbiologia de alimentos, o método de detecção dessas bactérias foi aplicado em amostras ambientais por MARTINS et al. (1991), durante os estudos realizados em três cemitérios do Estado de São Paulo. Esse método é baseado na hidrólise da gelatina pelas bactérias proteolíticas (VERA \& DUMOFF, 1974). O meio utilizado é um caldo nutriente onde são acrescentados $12 \%$ de gelatina. Pode-se também empregar meios prontos, como o Nutrient Gelatin OXOID. O meio foi distribuído em tubos e autoclavado a $121^{\circ} \mathrm{C}$ por $15 \mathrm{~min}$. Depois da amostra ter sido inoculada, os tubos foram incubados a $21^{\circ} \mathrm{C}\left( \pm 2^{\circ} \mathrm{C}\right)$ por 72 horas. Em seguida, foram dispostos a $4^{\circ} \mathrm{C}$ por duas horas. A liquefação do meio indicava a ocorrência da hidrólise. O número mais provável de bactérias foi determinado pela técnica de tubos múltiplos;

- Clostridium perfringes. O ensaio foi baseado na propriedade dos clostrídios sulfitoredutores de fermentar o leite tornassolado provocando a coagulação do caseinogênio, utilizando a técnica de tubos múltiplos descrita pela norma L5.213 da CETESB (1993b); 
- Vírus humanos. Realizada em caráter experimental, a pesquisa de vírus humanos nas amostras de água subterrânea do cemitério de Vila Nova Cachoeirinha é inédita, pois não há registros de estudos semelhantes em cemitérios. A pesquisa baseou-se na detecção de adenovírus e vírus pertencentes ao gênero Enterovirus, uma vez que estes são resistentes a diversos fatores ambientais como temperatura e pH. Além disto, são excretados em grandes concentrações pelas fezes dos indivíduos infectados, sendo freqüentemente isolados de águas de esgoto e de superfície. A concentração das partículas virais foi realizada conforme MEHNERT et al. (1997). O método molecular para detecção de adenovírus baseou-se na reação em cadeia da polimerase (PCR) para amplificação da seqüência gênica, utilizando o par de primers hexAA1885 e hexAA1913 (ALLARD et al., 1990). Para a detecção de enterovírus foram usados os primers Entero e Entero 1 (SCHWAB et al., 1995).

O programa de amostragem teve início em janeiro de 1999 com a coleta e análise de água dos primeiros poços construídos para os testes de traçador (P1-P4). Restrita a uma pequena porção do cemitério, estas amostragens tiveram um caráter experimental, definindo-se os indicadores a serem analisados. Com a construção dos novos poços, em julho de 1999, a amostragem ficou mais representativa abrangendo uma área maior do cemitério.

O Quadro 5.5 resume o programa de amostragem realizado no cemitério, indicando mensalmente os poços amostrados e os indicadores analisados. Entre setembro de 1999 e março de 2000, foram realizados seis programas de coleta para análise microbiológica (total de 54 amostras) e seis para análise química (total de 50 amostras). Devido a resultados insatisfatórios no balanço iônico de algumas análises químicas, um segundo laboratório (AMBIENTAL Laboratório e Equipamento Ltda.) foi contratado para realizar as análises das amostras coletadas no dia 21/03/00, em que foram utilizados frascos plásticos de $1000 \mathrm{~mL}$ com os preservantes adequados cedidos pelo laboratório citado. 
Quadro 5.5. Programa de amostragem no cemitério

\begin{tabular}{|c|c|c|c|c|c|}
\hline \multirow{2}{*}{ Data } & \multicolumn{5}{|c|}{ Parâmetros } \\
\hline & N.A. & T, pH, e outros & Íons & Bacteriológicos & Vírus \\
\hline $12 / 98$ & P1 a P4 & P1 a P4 & & & \\
\hline $01 / 99$ & P1 a P4 & & & $\mathrm{P} 1$ & \\
\hline $02 / 99$ & P1 a P4 & & & $\mathrm{P} 1$ & \\
\hline $03 / 99$ & P1 a P4 & $\mathrm{P} 1 \mathrm{a}$ P4 & & $\mathrm{P} 1$ & \\
\hline $04 / 99$ & P1 a P4 & P1 a P4 & & P1 & P1 \\
\hline $05 / 99$ & $\mathrm{P} 1 \mathrm{a}$ P4 & $\mathrm{P} 1$ a P4 & & $\mathrm{P} 1$ & $\mathrm{P} 1$ \\
\hline $06 / 99$ & P1 a P6 & $\mathrm{P} 1$ a P4 & & $\mathrm{P} 1$ & $\mathrm{P} 1$ \\
\hline $07 / 99$ & P1 a P18 & P1 a P10, P15 & & & \\
\hline $09 / 99$ & P1 a P20 & $\begin{array}{l}\text { P2, P4 a P11, } \\
\text { P15, P19, P20 }\end{array}$ & $\begin{array}{r}\mathrm{P} 4 \mathrm{a} \mathrm{P} 11, \mathrm{P} 13, \\
\mathrm{P} 15, \mathrm{P} 19 \mathrm{a} \\
\mathrm{P} 20\end{array}$ & $\begin{array}{r}\mathrm{P} 1, \mathrm{P} 2, \mathrm{P} 4 \text { a P11, } \\
\mathrm{P} 13, \mathrm{P} 15, \mathrm{P} 19, \mathrm{P} 20\end{array}$ & \\
\hline $10 / 99$ & P1 a P20 & $\begin{array}{r}\mathrm{P} 2, \mathrm{P} 4 \text { a P10, } \mathrm{P} 15, \\
\mathrm{P} 20\end{array}$ & $\begin{array}{r}\mathrm{P} 2, \mathrm{P} 4 \mathrm{a} \mathrm{P} 10, \\
\mathrm{P} 15, \mathrm{P} 19 \mathrm{a} \\
\mathrm{P} 20\end{array}$ & $\begin{array}{r}\mathrm{P} 1 \text { a P2, P4 a P7, } \\
\mathrm{P} 9 \text { a P10, } \\
\mathrm{P} 13, \mathrm{P} 15, \mathrm{P} 19 \text { a } \\
\mathrm{P} 20\end{array}$ & $\begin{array}{r}\text { P5, P8, } \\
\text { P10 }\end{array}$ \\
\hline $11 / 99$ & P5 a P11 & P5 a P10 & P5 a P10 & P5 a P10 & \\
\hline $12 / 99$ & $\begin{array}{r}\text { P1 a P4, } \\
\text { P13 a P20 }\end{array}$ & $\begin{array}{r}\mathrm{P} 1 \text { a P4, P13, } \\
\text { P15, P20 }\end{array}$ & $\begin{array}{r}\mathrm{P} 1 \text { a } \mathrm{P} 4, \mathrm{P} 13, \\
\mathrm{P} 15, \mathrm{P} 20\end{array}$ & $\begin{array}{l}\mathrm{P} 2 \text { a } \mathrm{P} 4, \mathrm{P} 13, \\
\mathrm{P} 15, \mathrm{P} 19, \mathrm{P} 20\end{array}$ & \\
\hline $01 / 00$ & P1 a P20 & $\begin{array}{r}\text { P1 a P10, P13, } \\
\text { P15 a 17, P19 a P20 }\end{array}$ & & & \\
\hline $02 / 00$ & P1 a P20 & $\begin{array}{r}\text { P1 a P10, P12, P13, } \\
\text { P15 a P17, P19 }\end{array}$ & $\begin{array}{l}\text { P5 a P10, } \\
\text { P19 a P20 }\end{array}$ & P5 a P10, P19, P20 & $\begin{array}{r}\mathrm{P} 5, \mathrm{P} 8, \\
\mathrm{P} 10\end{array}$ \\
\hline $03 / 00$ & $\begin{array}{r}\text { P5 a P10, P13, } \\
\text { P15 a P16, } \\
\text { P19 }\end{array}$ & P5 a P10 & P5 a P10 & P5 a P10 & $\begin{array}{r}\text { P5, P8, } \\
\text { P10 }\end{array}$ \\
\hline $05 / 00$ & P1 a P20 & $\begin{array}{l}\text { P1 a P10, P12, P13, } \\
\text { P15 a P16, P19 a P20 }\end{array}$ & & & \\
\hline
\end{tabular}




\section{RESULTADOS}

\subsection{Etapa de laboratório}

\subsubsection{Colunas de solo}

As colunas foram preenchidas com dois solos com características diferentes. O solo denominado 1, coletado fora do cemitério, é predominantemente arenoso (90\%) com apenas 6\% de argila, com $\mathrm{pH}=4,0$, pouca matéria orgânica $(0,5 \%)$ e baixa capacidade de troca de cátions (45,6 mmolc/kg). O solo 2, proveniente do cemitério de Vila Nova Cachoeirinha, possui mais de $40 \%$ de argila, $\mathrm{pH}=5,0$, com $0,5 \%$ de matéria orgânica e também baixa capacidade de troca de cátions $(35,3 \mathrm{mmolc} / \mathrm{kg})$. A Tabela 6.1 mostra as características físicas e químicas dos dois solos, cujas análises foram realizadas pelo Laboratório de Análises de Solos - Departamento de Ciência do Solo da Escola Superior de Agricultura Luiz de Queiroz da USP.

Tabela 6.1 Características físico-químicas dos solos das colunas

\begin{tabular}{lcc}
\hline \multicolumn{1}{c}{ Parâmetro } & Solo 1 & Solo 2 \\
\hline Frações do solo & & \\
$\quad$ Argila & $6 \%$ & $46 \%$ \\
Silte & $4 \%$ & $22 \%$ \\
Frações de areia & & \\
0,05-0,10 mm & $6 \%$ & $2 \%$ \\
0,10-0,25 mm & $23 \%$ & $7 \%$ \\
$\quad 0,25-0,50 \mathrm{~mm}$ & $22 \%$ & $6 \%$ \\
$\quad 0,50-1,00 \mathrm{~mm}$ & $24 \%$ & $12 \%$ \\
$\quad 1,00-2,00 \mathrm{~mm}$ & $15 \%$ & $5 \%$ \\
Textura & arenosa & argilosa \\
Diâmetro médio dos grãos & $0,53 \mathrm{~mm}$ & $0,21 \mathrm{~mm}$ \\
$\mathrm{pH}$ & 4,0 & 5,0 \\
Matéria orgânica & $5 \mathrm{~g} / \mathrm{kg}$ & $5 \mathrm{~g} / \mathrm{kg}$ \\
Capacidade de troca de cátions & $45,6 \mathrm{mmolc} / \mathrm{kg}$ & $35,3 \mathrm{mmolc} / \mathrm{kg}$ \\
$\mathrm{P}$ & $4 \mathrm{mg} / \mathrm{kg}$ & $2 \mathrm{mg} / \mathrm{kg}$ \\
$\mathrm{K}$ & $0,6 \mathrm{mmolc} / \mathrm{kg}$ & $0,3 \mathrm{mmolc} / \mathrm{kg}$ \\
$\mathrm{Ca}$ & $14 \mathrm{mmolc} / \mathrm{kg}$ & $7 \mathrm{mmolc} / \mathrm{kg}$ \\
$\mathrm{Mg}$ & $3 \mathrm{mmolc} / \mathrm{kg}$ & $2 \mathrm{mmolc} / \mathrm{kg}$ \\
$\mathrm{Al}$ & $24 \mathrm{mmolc} / \mathrm{kg}$ & $0 \mathrm{mmolc} / \mathrm{kg}$ \\
\hline
\end{tabular}


As colunas de solo foram montadas no Laboratório de Microbiologia Ambiental do Instituto de Ciências Biomédicas da USP, entre julho de 1998 e fevereiro de 2000. A Tabela 6.2 mostra o tipo de solo, o comprimento das colunas montadas, valores médios observados da condutividade hidráulica $K$ em dois dos seis experimentos. Os valores de $K$ para cada coluna foram obtidos a partir da regressão linear de $q(Q / A)$ em função de $d h / d l$.

Tabela 6.2 Comprimento e condutividade hidráulica das colunas de solos

\begin{tabular}{ccc}
\hline Coluna & $\begin{array}{c}\text { Comprimento Cond. Hidráulica } \\
L(\mathrm{~m})\end{array}$ & $K(\mathrm{~m} / \mathrm{s})$ \\
\hline Solo arenoso & 0,40 & $1,69 \mathrm{E}-4$ \\
Solo argiloso & 0,34 & $1,00 \mathrm{E}-5$ \\
\hline
\end{tabular}

\subsubsection{Traçador biológico}

Mostrado no capítulo anterior, o traçador biológico escolhido foi o bacteriófago T4. As concentrações obtidas do T4 variaram entre $10^{7}$ e $10^{10} \mathrm{UFP} / \mathrm{mL}$, sendo produzidas alíquotas entre 100 e $500 \mathrm{~mL}$ destinadas aos experimentos de inativação, adsorção e injeção do traçador.

\subsubsection{Inativação do colifago $\mathrm{T} 4$}

Os testes para determinação da inativação dos colifagos foram realizados à temperatura de $25^{\circ} \mathrm{C}$ com $\mathrm{pH}=5,0$ para o efluente da coluna de solo 1 e $\mathrm{pH}=6,5$ para a coluna de solo 2 . A Tabela 6.3 mostra as concentrações do colifago T4 observadas ao longo do tempo. Os experimentos foram realizados em duplicatas (erlenmeyers 1 e 2), e as amostras tituladas em triplicatas (valores médios são apresentados). 
Tabela 6.3 Concentração $(C)$ do colifago T4 ao longo do tempo em dois pHs

\begin{tabular}{ccc}
\hline$T=25^{\circ} \mathrm{C}, \mathrm{pH}=5,0$ & \multicolumn{2}{c}{$C(\mathrm{UFP} / \mathrm{mL})$} \\
\cline { 2 - 3 } Tempo $(\mathrm{h})$ & Erlenmeyer 1 & Erlenmeyer 2 \\
\hline 0 & $9 \mathrm{E} 9$ & $9 \mathrm{E} 9$ \\
1,5 & $89 \mathrm{E} 8$ & $53 \mathrm{E} 8$ \\
27 & $56 \mathrm{E} 8$ & $39 \mathrm{E} 8$ \\
51 & $32 \mathrm{E} 8$ & $27 \mathrm{E} 8$ \\
76 & $32 \mathrm{E} 8$ & $27 \mathrm{E} 8$ \\
\hline$T=25^{\circ} \mathrm{C}, \mathrm{pH}=6,5$ & \multicolumn{2}{c}{$C(\mathrm{UFP} / \mathrm{mL})$} \\
\cline { 2 - 3 } Tempo $(\mathrm{h})$ & Erlenmeyer 1 & Erlenmeyer 2 \\
\hline 0 & $2 \mathrm{E} 7$ & $5 \mathrm{E} 7$ \\
24 & $2 \mathrm{E} 7$ & $1 \mathrm{E} 7$ \\
48 & $7 \mathrm{E} 6$ & $5 \mathrm{E} 6$ \\
72 & $2 \mathrm{E} 7$ & $2 \mathrm{E} 7$ \\
96 & $2 \mathrm{E} 7$ & $2 \mathrm{E} 7$ \\
120 & $2 \mathrm{E} 7$ & $6 \mathrm{E} 6$ \\
144 & $6 \mathrm{E} 6$ & $5 \mathrm{E} 6$ \\
168 & $1 \mathrm{E} 6$ & $1 \mathrm{E} 6$ \\
192 & $2 \mathrm{E} 7$ & $5 \mathrm{E} 6$ \\
216 & $1 \mathrm{E} 7$ & $1 \mathrm{E} 7$ \\
240 & $1 \mathrm{E} 7$ & $2 \mathrm{E} 7$ \\
\hline
\end{tabular}

A Figura 6.1 mostra a concentração relativa $\left(C / C_{0}\right)$ ao longo do tempo no experimento de inativação para o $\mathrm{pH}=5,0$. Uma função exponencial $\left(C=C_{0} e^{-\lambda t}\right)$ foi ajustada aos dados por mínimos quadrados, obtendo-se a constante de inativação $\lambda=0,012 \mathrm{~h}^{-1}$. Da equação 5.1 , a meia vida $\left(\tau_{1 / 2}\right)$ do colifago foi determinada em $58 \mathrm{~h}$. Já para o $\mathrm{pH}=6,5$, outra função exponencial foi ajustada aos dados (Figura 6.2), onde foram determinados $\lambda=0,004 \mathrm{~h}^{-1} \mathrm{e} \tau_{1 / 2}=161 \mathrm{~h}$.

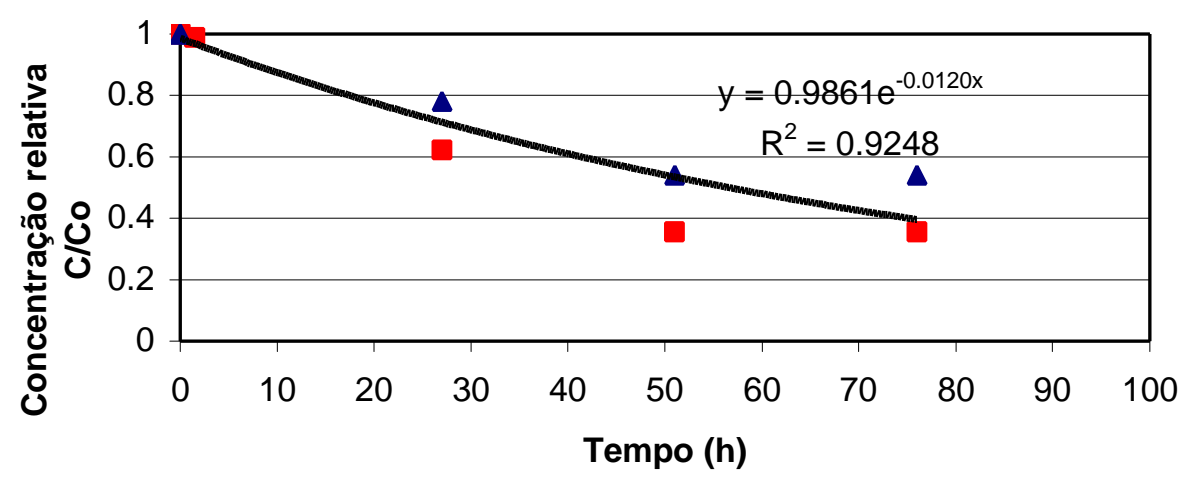

- Erlenmeyer 1 \ Erlenmeyer 2 - Expon.

Figura 6.1 Concentração relativa $\left(C / C_{0}\right)$ do colifago T4 ao longo do tempo $(\mathrm{pH}=5,0)$ 


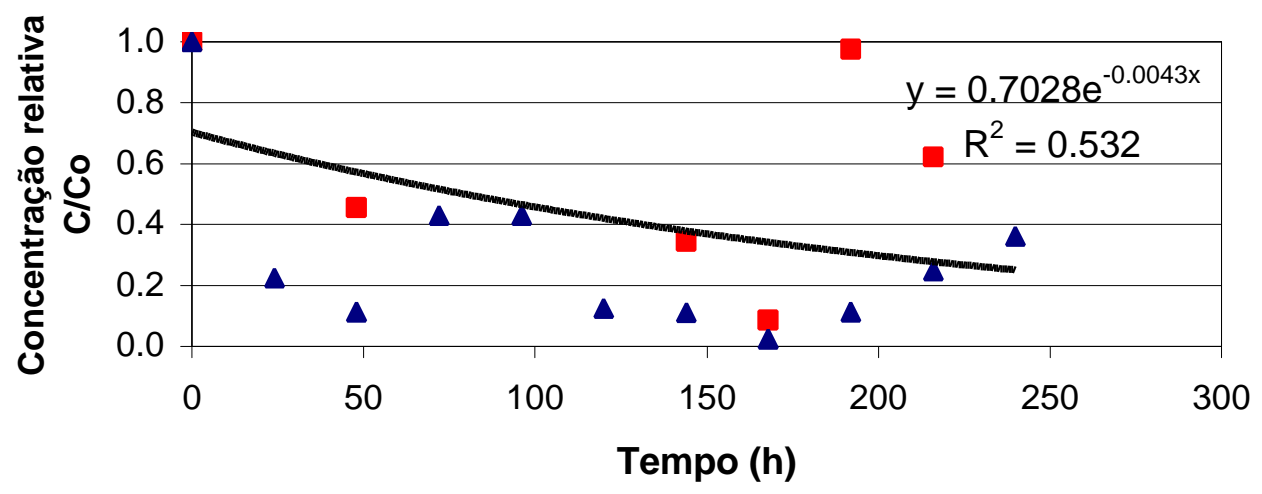

\section{- Erlenmeyer 1 \ Erlenmeyer 2 - Expon.}

Figura 6.2 Concentração relativa $\left(C / C_{0}\right)$ do colifago T4 ao longo do tempo $(\mathrm{pH}=6,5)$

\subsubsection{Adsorção do colifago T4}

Isotermas de adsorção do colifago T4 nos solos 1 e 2 foram ajustadas às concentrações em equilíbrio $(C)$ e quantidade adsorvida $\left(C^{*}\right)$ observadas em experimentos in vitro realizados a temperatura ambiente de $25^{\circ} \mathrm{C}$ (Tabela 6.4). As concentrações inicial $\left(C_{o}\right)$ e em equilíbrio $(C)$ da tabela são valores médios das titulações realizadas em triplicatas. $\mathrm{O}$ valor de $C^{*}$ foi determinado subtraindo $C$ de $C_{o}$ e multiplicando este resultado pelo volume da solução (15 mL para o solo 1 e $30 \mathrm{~mL}$ para o solo 2) e dividindo pelo peso da amostra de solo seco (15 g). A concentração em equilíbrio $C$ foi corrigida para a inativação sofrida pelo T4 durante o teste de adsorção $(1,5 \mathrm{~h})$, de acordo com as equações determinadas no item anterior, considerando a constante de inativação $\lambda=0,012 \mathrm{~h}^{-1}$ no efluente da coluna de solo 1 e $\lambda=0,004 \mathrm{~h}^{-1}$ no efluente da coluna de solo 2 .

A relação existente entre a quantidade de fagos adsorvidos pelos solos e a concentração destes em equilíbrio é mostrada na Figura 6.3. A isoterma de adsorção linear (FETTER, 1999) foi ajustada aos dados obtidos de adsorção dos colifagos T4 nos solos. A Tabela 6.5 mostra o coeficientes de distribuição determinados e respectivos coeficiente de determinação $\left(R^{2}\right)$ para os solos 1 e 2. As curvas foram ajustadas por mínimos quadrados e alguns valores extremos foram excluídos. Se considerarmos a isoterma de adsorção linear como a mais adequada para representar a adsorção, temos o coeficiente de partição ou distribuição $K_{d}=51 \mathrm{~mL} / \mathrm{g}$ para o solo 1 e $295 \mathrm{~mL} / \mathrm{g}$ para o solo 2. 
Tabela 6.4 Concentrações do colifago T4 no teste de adsorção nos solos

\begin{tabular}{cccc}
\hline $\begin{array}{c}\text { Conc. Inicial } \\
C_{o}(\mathrm{UFP} / \mathrm{mL})\end{array}$ & $\begin{array}{c}\text { Conc. em equilíbrio } \\
C(\mathrm{UFP} / \mathrm{mL})\end{array}$ & $\begin{array}{c}\text { Quant. adsorvida } \\
C^{*}(\mathrm{UFP} / \mathrm{g})\end{array}$ & Solo \\
\hline $1 \mathrm{E} 9$ & $6 \mathrm{E} 8$ & $3 \mathrm{E} 8$ & 1 \\
$1 \mathrm{E} 9$ & $2 \mathrm{E} 6$ & $10 \mathrm{E} 7$ & 1 \\
$1 \mathrm{E} 9$ & $2 \mathrm{E} 5$ & $10 \mathrm{E} 6$ & 1 \\
$1 \mathrm{E} 8$ & $9 \mathrm{E} 8$ & $8 \mathrm{E} 7$ & 1 \\
$1 \mathrm{E} 8$ & $2 \mathrm{E} 6$ & $10 \mathrm{E} 7$ & 1 \\
$1 \mathrm{E} 8$ & $2 \mathrm{E} 5$ & $10 \mathrm{E} 6$ & 1 \\
$1 \mathrm{E} 7$ & $9 \mathrm{E} 8$ & $8 \mathrm{E} 7$ & 1 \\
$1 \mathrm{E} 7$ & $2 \mathrm{E} 6$ & $10 \mathrm{E} 7$ & 1 \\
$1 \mathrm{E} 7$ & $2 \mathrm{E} 5$ & $10 \mathrm{E} 6$ & 1 \\
$2 \mathrm{E} 9$ & $1 \mathrm{E} 7$ & $4 \mathrm{E} 9$ & 2 \\
$2 \mathrm{E} 9$ & $2 \mathrm{E} 6$ & $4 \mathrm{E} 7$ & 2 \\
$2 \mathrm{E} 9$ & $1 \mathrm{E} 5$ & $4 \mathrm{E} 6$ & 2 \\
$2 \mathrm{E} 8$ & $1 \mathrm{E} 4$ & $4 \mathrm{E} 9$ & 2 \\
$2 \mathrm{E} 8$ & $1 \mathrm{E} 7$ & $4 \mathrm{E} 8$ & 2 \\
$2 \mathrm{E} 8$ & $1 \mathrm{E} 6$ & $4 \mathrm{E} 7$ & 2 \\
$2 \mathrm{E} 7$ & $1 \mathrm{E} 5$ & $4 \mathrm{E} 6$ & 2 \\
$2 \mathrm{E} 7$ & $1 \mathrm{E} 4$ & $4 \mathrm{E} 9$ & 2 \\
$2 \mathrm{E} 7$ & $1 \mathrm{E} 7$ & $4 \mathrm{E} 8$ & 2 \\
$2 \mathrm{E} 6$ & $3 \mathrm{E} 6$ & $4 \mathrm{E} 7$ & 2 \\
$2 \mathrm{E} 6$ & $1 \mathrm{E} 5$ & $4 \mathrm{E} 6$ & 2 \\
$2 \mathrm{E} 6$ & $1 \mathrm{E} 4$ & &
\end{tabular}

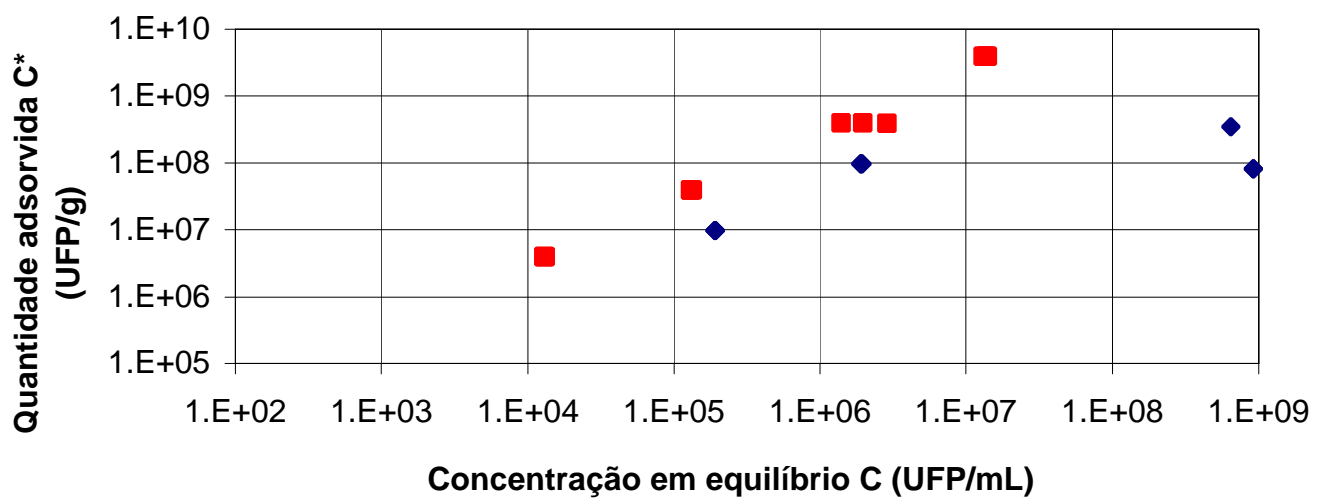

- solo 1 solo 2

Figura 6.3 Quantidade adsorvida $\left(C^{*}\right)$ em função da concentração em equilíbrio $(C)$ do T4 
Tabela 6.5 Ajuste da isoterma de adsorção linear aos dados observados

\begin{tabular}{ccc}
\hline Isoterma de sorção linear & $\begin{array}{c}\text { Coeficiente de distribuição } \\
C^{*}=K_{d} C\end{array}$ & $R^{2}$ \\
\hline Solo 1 (arenoso) & $K_{d}(\mathrm{~mL} / \mathrm{g})$ & \\
Solo 2 (argiloso) & 51 & 0,99 \\
\hline
\end{tabular}

\subsubsection{Injeção dos traçadores}

O fluxo de água nas colunas de solos foi mantido constante durante os experimentos de injeção. Os traçadores químico e biológico foram injetados nas colunas como mostrado no capítulo anterior. Os modelos numéricos foram ajustados aos dados observados, sendo estimados a dispersividade $\alpha$ e o coeficiente de partição $K_{d}$.

\section{Coluna de solo arenoso}

Os primeiros experimentos de injeção foram realizados com o solo de textura arenosa. A Figura 6.4 mostra a carga hidráulica ao longo da coluna de solo arenoso determinada através da solução numérica por diferenças finitas da equação de Laplace. A Figura 6.5 compara os valores de carga hidráulica observados nos manômetros 1 e 2 com os valores calculados, para a calibração do modelo numérico.

A Figura 6.6 mostra a concentração relativa $\left(C / C_{0}\right)$ do cloreto, ao longo do tempo, obtida a partir da medição da condutividade elétrica $(\mu \mathrm{S} / \mathrm{cm})$ na saída da coluna, após a injeção de 40 $\mathrm{mL}$ do cloreto na concentração $C_{0}=3.400 \mathrm{mg} / \mathrm{L}$ em $t=0$ e $x=0$. O tempo correspondente ao pico da curva da Figura $6.6\left(t_{\max }=19 \mathrm{~min}\right)$ foi utilizado para determinar a porosidade efetiva $n_{e}=$ 0,3. A figura ainda apresenta a solução numérica ajustada aos dados para determinação da dispersividade $\alpha=0,003 \mathrm{~m}$. 


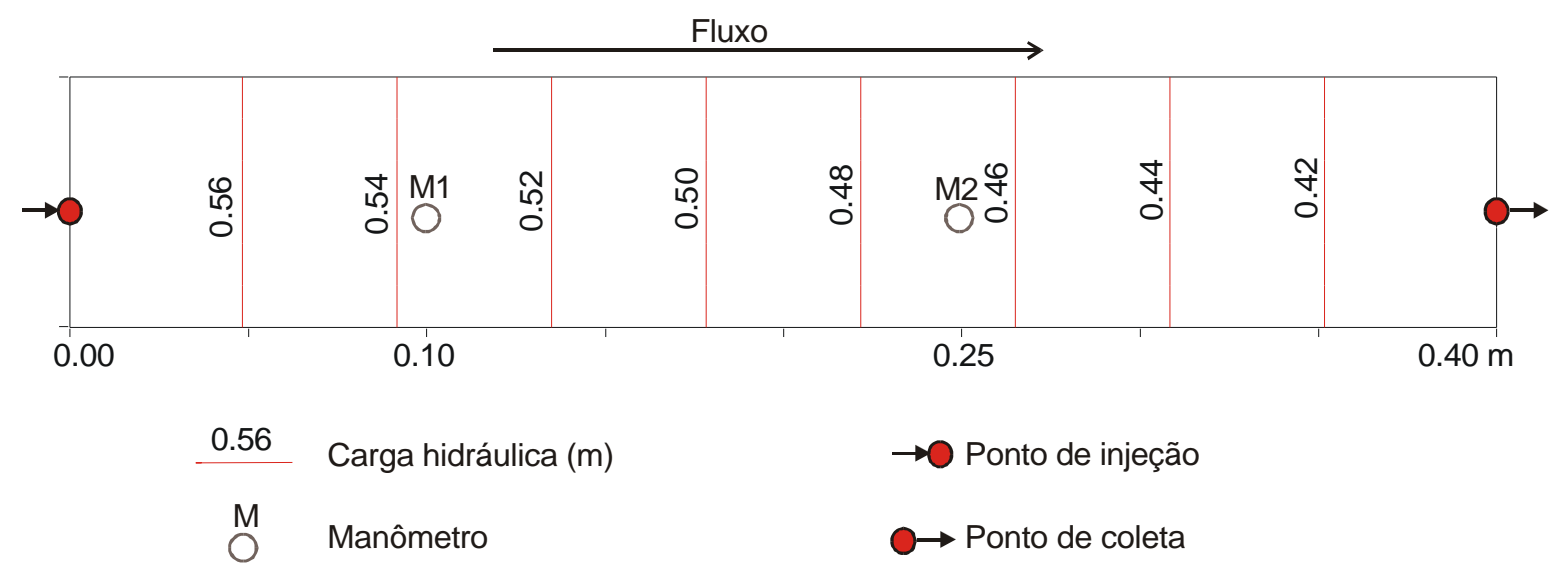

Figura 6.4 Carga hidráulica calculada ao longo da coluna de solo arenoso

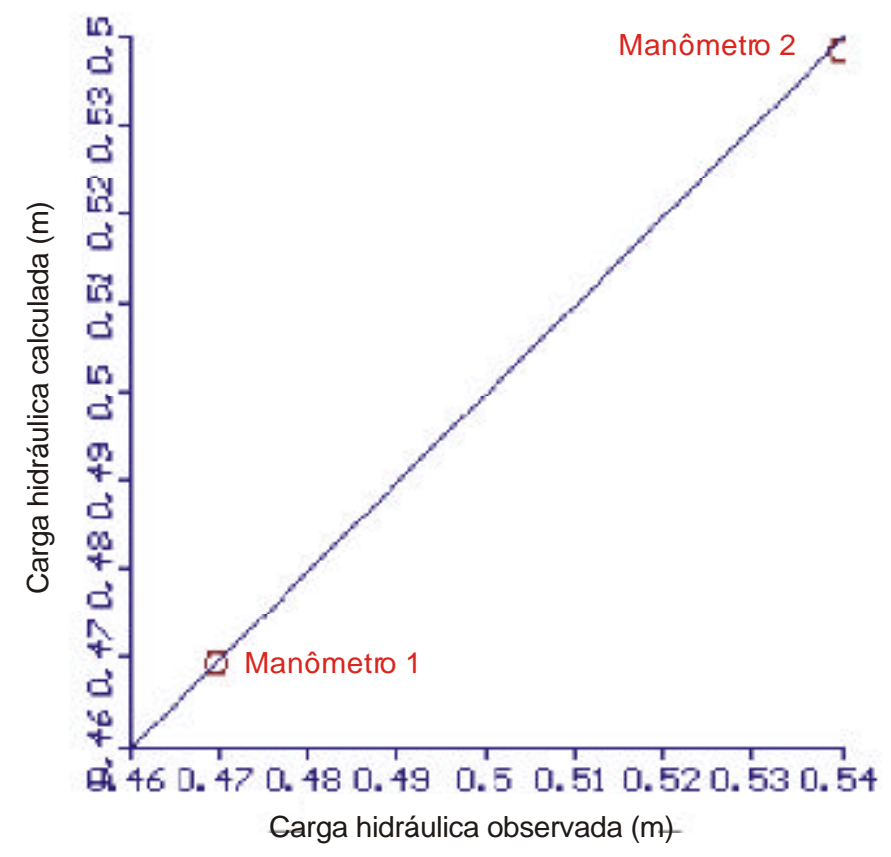

Figura 6.5 Relação entre valores de carga hidráulica (m) calculados e observados 


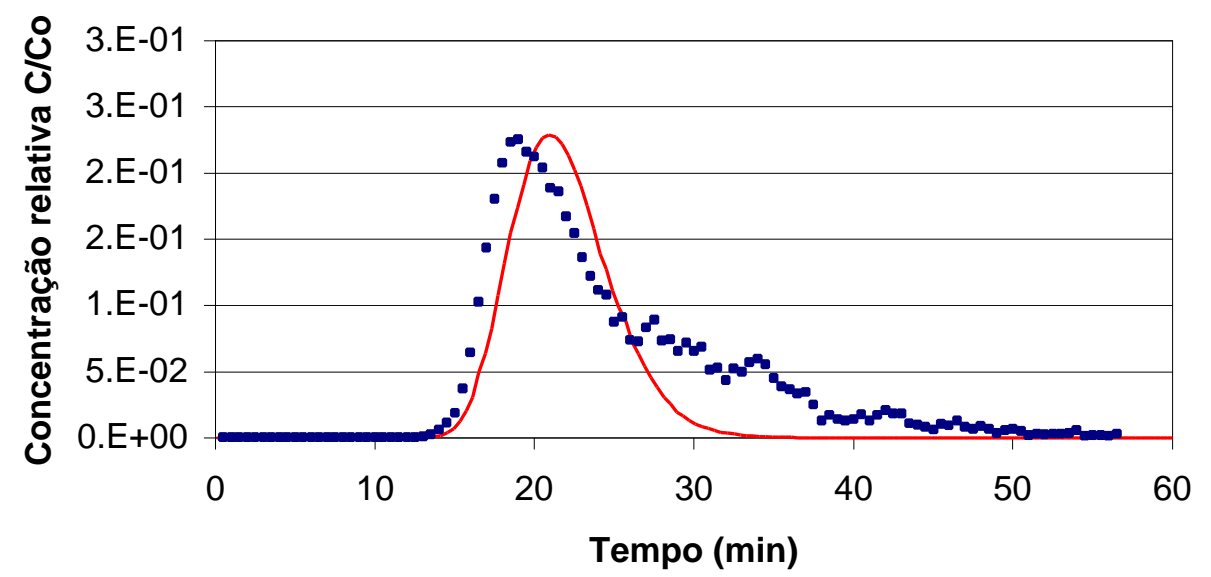

- Observado — Modelo numérico

Figura 6.6 Concentração relativa $\left(C / C_{0}\right)$ do cloreto no efluente da coluna de solo arenoso

A Tabela 6.6 mostra a concentração observada do colifago T4 no efluente após a injeção de $10 \mathrm{~mL}$ do traçador na concentração $C_{0}=1,3 \mathrm{E} 9 \mathrm{UFP} / \mathrm{mL}$ em $t=0$ e $x=0$. O modelo numérico ajustado levou em consideração a adsorção e inativação do T4. A Figura 6.7 mostra a concentração do T4 observada no efluente da coluna e o modelo ajustado. A Tabela 6.7 mostra os valores de condutividade hidráulica $K$, dispersividade $\alpha$, coeficiente de partição $K_{d}$ e constante de inativação $\lambda$ estimados para a coluna de solo arenoso.

Tabela 6.6 Concentração observada do T4 no efluente da coluna de solo arenoso

\begin{tabular}{cc|cc}
\hline Tempo $(\mathrm{min})$ Concentração $C(\mathrm{UFP} / \mathrm{mL})$ & Tempo $(\mathrm{min})$ Concentração $C(\mathrm{UFP} / \mathrm{mL})$ \\
\hline 0 & $0,00 \mathrm{E} 0$ & 255 & $6,00 \mathrm{E} 5$ \\
15 & $1,30 \mathrm{E} 3$ & 285 & $9,00 \mathrm{E} 4$ \\
30 & $2,00 \mathrm{E} 5$ & 315 & $2,70 \mathrm{E} 5$ \\
45 & $1,20 \mathrm{E} 7$ & 345 & $9,00 \mathrm{E} 4$ \\
60 & $4,40 \mathrm{E} 6$ & 375 & $1,65 \mathrm{E} 5$ \\
75 & $8,10 \mathrm{E} 6$ & 405 & $2,00 \mathrm{E} 4$ \\
90 & $6,10 \mathrm{E} 6$ & 435 & $1,91 \mathrm{E} 5$ \\
105 & $4,30 \mathrm{E} 6$ & 450 & $2,00 \mathrm{E} 4$ \\
135 & $2,30 \mathrm{E} 6$ & 480 & $2,50 \mathrm{E} 5$ \\
165 & $2,80 \mathrm{E} 6$ & 495 & $4,33 \mathrm{E} 5$ \\
195 & $1,00 \mathrm{E} 6$ & 510 & $3,00 \mathrm{E} 4$ \\
225 & $1,36 \mathrm{E} 6$ & & \\
\hline
\end{tabular}




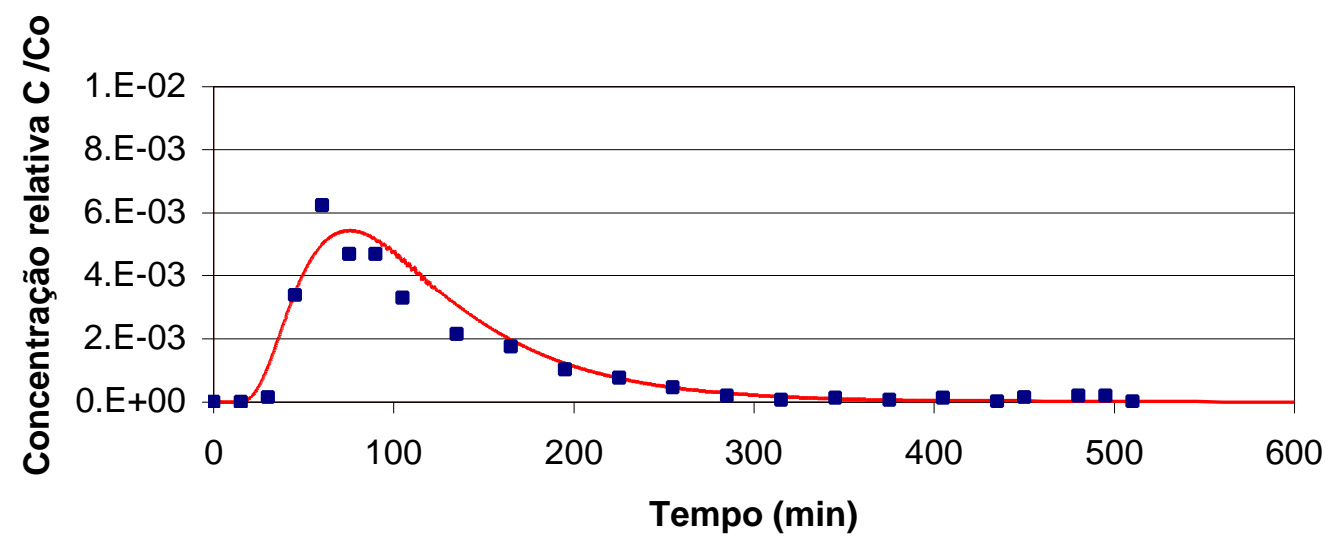

- Observado — Modelo numérico

Figura 6.7 Concentração relativa $\left(C / C_{0}\right)$ do $\mathrm{T} 4$ no efluente da coluna de solo arenoso

Tabela 6.7 Parâmetros determinados na coluna de solo arenoso

Condutividade hidráulica Dispersividade Coef. de distribuição Const. de inativação

\begin{tabular}{cccc}
$K(\mathrm{~m} / \mathrm{s})$ & $\alpha(\mathrm{m})$ & $K_{d}(\mathrm{~mL} / \mathrm{g})$ & $\lambda\left(\mathrm{h}^{-1}\right)$ \\
\hline $1,69 \mathrm{E}-4$ & 0,08 & 0,4 & 0,012 \\
\hline
\end{tabular}

\section{Coluna de solo do cemitério}

A Figura 6.8 mostra a concentração relativa $\left(C / C_{0}\right)$ do cloreto em função do tempo no efluente da coluna de solo do cemitério de Vila Nova Cachoeirinha. Foram injetados $100 \mathrm{~mL}$ do traçador químico na concentração $C_{0}=5100 \mathrm{mg} / \mathrm{L}$. A figura também mostra a solução numérica ajustada aos dados para determinação da dispersividade $\alpha=0,2 \mathrm{~m}$. A Figura 6.9 mostra a concentração do T4 no efluente da coluna, para uma concentração inicial $C_{0}$ de $16 \mathrm{E} 8 \mathrm{UFP} / \mathrm{mL}$ e a solução numérica com a determinação de condutividade hidráulica $K$, dispersividade $\alpha$, coeficiente de partição $K_{d}$ e constante de inativação $\lambda$ (Tabela 6.8). 


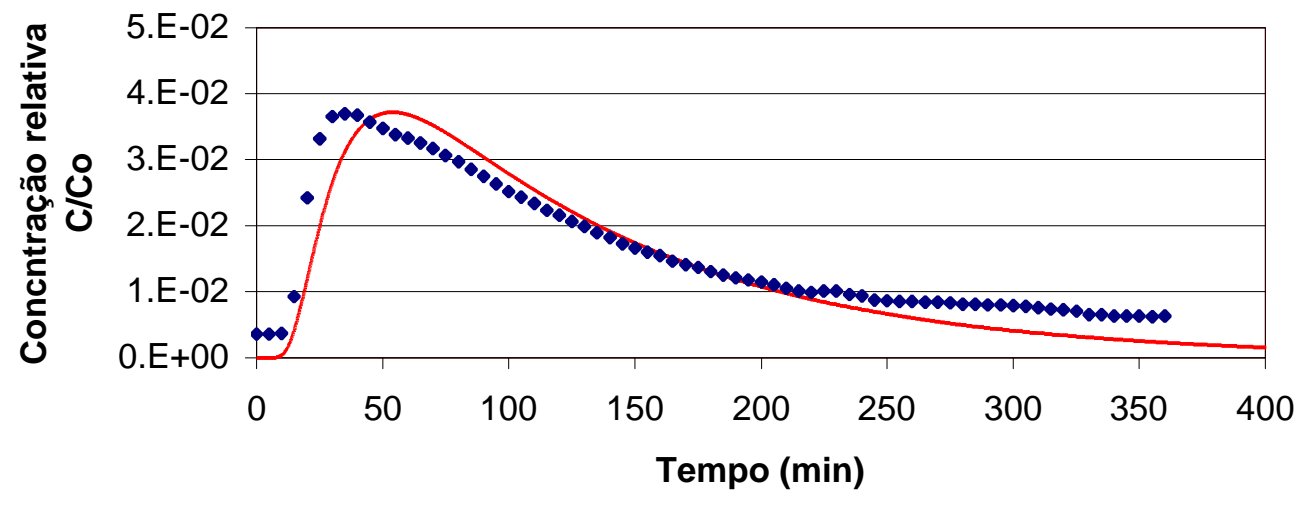

- Observado - Modelo

Figura 6.8 Concentração relativa $\left(C / C_{0}\right)$ do cloreto no efluente da coluna de solo do cemitério

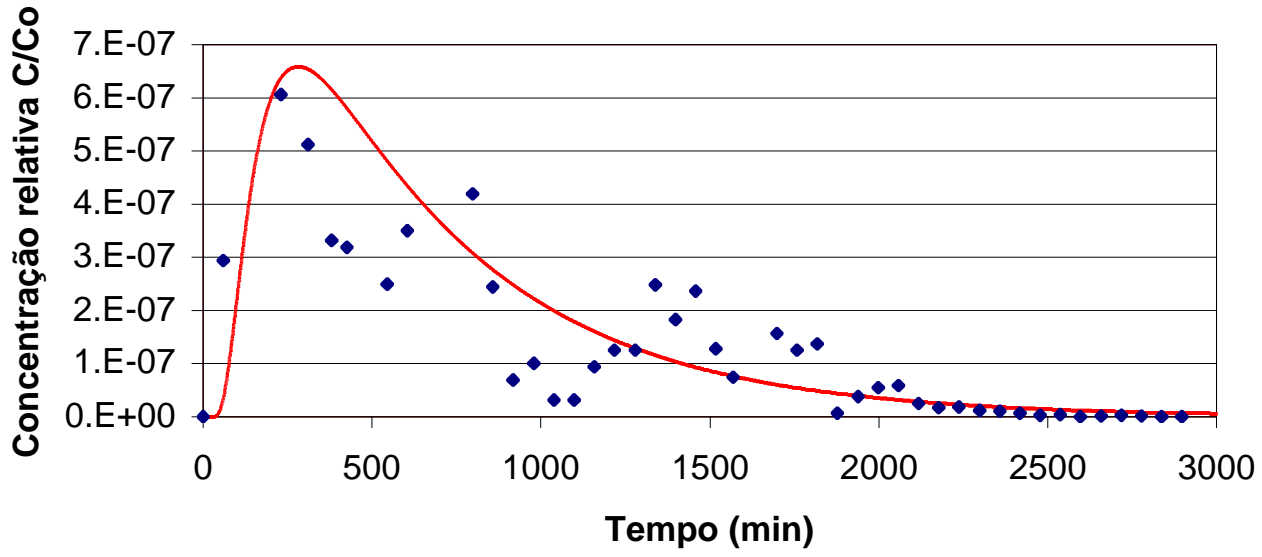

- Observado — Modelo

Figura 6.9 Concentração relativa $\left(C / C_{0}\right)$ do $\mathrm{T} 4$ no efluente da coluna de solo do cemitério

Tabela 6.8 Parâmetros determinados na coluna de solo do cemitério

Condutividade hidráulica Dispersividade Coef. de distribuição Const. de inativação $K(\mathrm{~m} / \mathrm{s})$ $\alpha(\mathrm{m})$ $K_{d}(\mathrm{~mL} / \mathrm{g})$ $\lambda\left(\mathrm{h}^{-1}\right)$

$1 \mathrm{E}-5$

0,2




\subsection{Etapa de campo}

\subsubsection{Sondagem elétrica e caminhamento eletromagnético}

As medições de resistividade aparente das oito sondagens elétricas verticais (SEVs) e os respectivos modelos geoelétricos estão no Anexo 2. A Tabela 6.9 mostra os valores de espessura (m) e resistividade (ohm.m) determinados pelos modelos e as profundidades inferidas do topo da camada saturada e do embasamento.

De acordo com os modelos geoelétricos, o embasamento no cemitério está a uma profundidade de 9,0 m na cota mais baixa (SEV-8) e 20,5 m no topo (SEV-5). A profundidade até a camada saturada varia de 1,0 (SEV-8) a 12,1 m (SEV-5).

Tabela 6.9 Resultados dos modelos geoelétricos de camadas

\begin{tabular}{|c|c|c|c|c|c|c|c|c|}
\hline \multirow{2}{*}{$\begin{array}{l}\text { Sondagem } \\
\text { Elétrica }\end{array}$} & & \multicolumn{5}{|c|}{ Camada } & \multicolumn{2}{|c|}{ Profundidade (m) (topo) } \\
\hline & & 1 & 2 & 3 & 4 & 5 & camada saturada & embasamento \\
\hline \multirow[t]{2}{*}{$\begin{array}{l}\text { SEV-1 } \\
\text { S }\end{array}$} & Espessura (m) & 1,0 & 3,0 & 10,0 & & & 4,0 & 14,0 \\
\hline & $\rho$ (ohm.m) & 220 & 680 & 165 & 520 & & & \\
\hline \multirow[t]{2}{*}{ SEV-2 } & Espessura (m) & 2,0 & 2,0 & 10,0 & & & 4,0 & 14,0 \\
\hline & $\rho$ (ohm.m) & 230 & 600 & 380 & 1.000 & & & \\
\hline \multirow[t]{2}{*}{ SEV-3 } & Espessura (m) & 1,5 & 4,0 & 10,0 & & & 5,5 & 15,5 \\
\hline & $\rho$ (ohm.m) & 90 & 500 & 350 & 550 & & & \\
\hline \multirow[t]{2}{*}{ SEV-4 } & Espessura (m) & 2,0 & 16,0 & & & & 2,0 & 18,0 \\
\hline & $\rho$ (ohm.m) & 90 & 35 & 530 & & & & \\
\hline \multirow[t]{2}{*}{ SEV-5 } & Espessura (m) & 3,5 & 2,1 & 6,5 & 8,4 & & 12,1 & 20,5 \\
\hline & $\rho$ (ohm.m) & 264 & 38 & 730 & 91 & 700 & & \\
\hline \multirow[t]{2}{*}{ SEV-6 } & Espessura (m) & 1,8 & 2,0 & 6,0 & 3,0 & & 9,8 & 12,8 \\
\hline & $\rho$ (ohm.m) & 190 & 50 & 350 & 8 & 300 & & \\
\hline \multirow[t]{2}{*}{ SEV-7 } & Espessura (m) & 2,5 & 14,0 & & & & 2,5 & 16,5 \\
\hline & $\rho$ (ohm.m) & 450 & 150 & 1.400 & & & & \\
\hline \multirow[t]{2}{*}{ SEV-8 } & Espessura (m) & 1,0 & 8,0 & & & & 1,0 & 9,0 \\
\hline & $\rho$ (ohm.m) & 540 & 50 & 2.000 & & & & \\
\hline
\end{tabular}

A Figura 6.10 mostra o corte transversal AA' no cemitério, são apresentados os valores de resistividade estimados pelos modelos, as profundidades do topo da camada saturada e do 


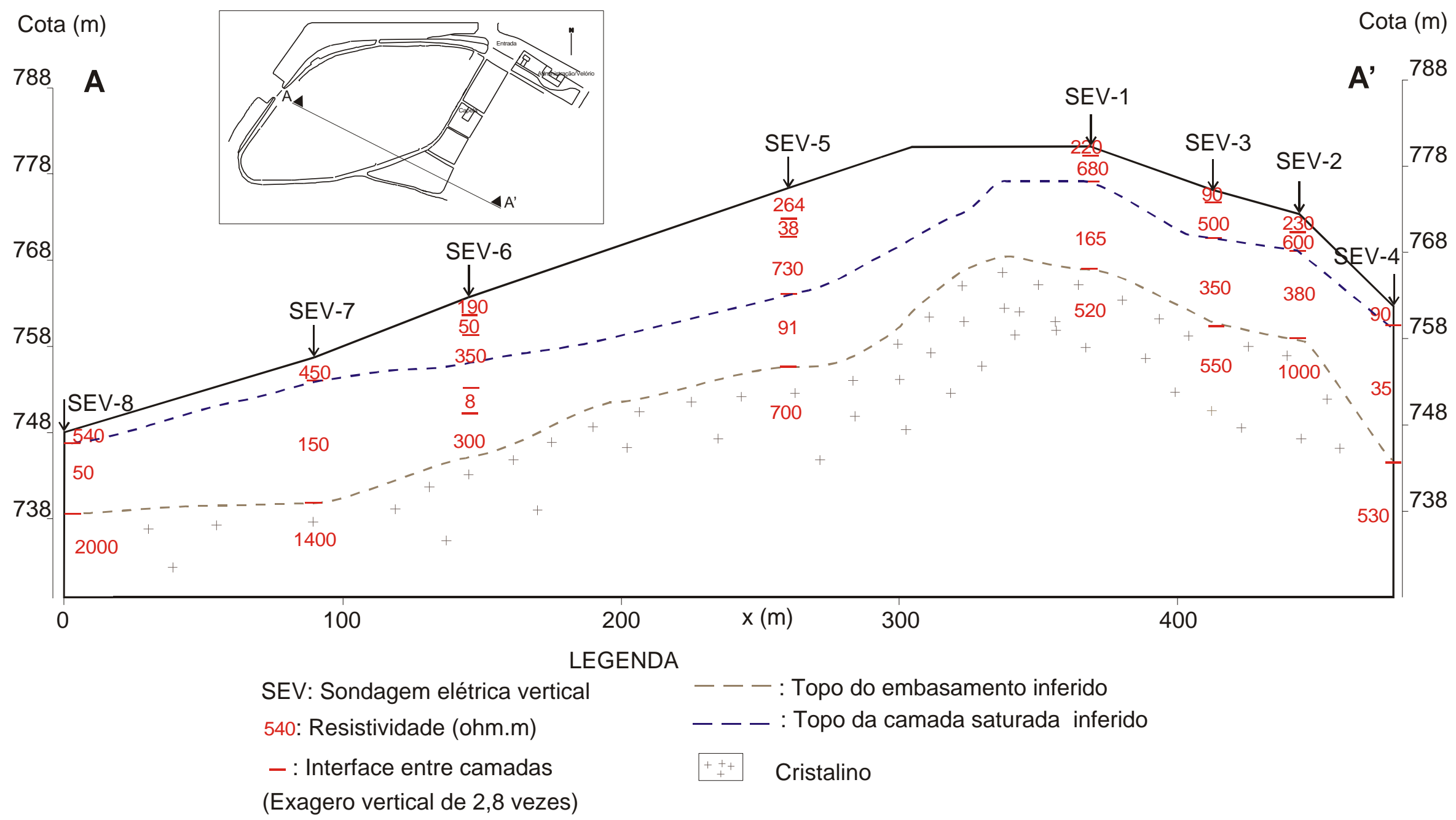

Figura 6.10 Seção geoelétrica AA' 
embasamento obtidos a partir das informações das sondagens elétricas e geológicas e dos poços tubulares próximos da área de estudos.

As figuras 6.11 e 6.12 mostram mapas do cemitério com isolinhas de condutividade elétrica aparente determinadas a partir dos valores observados nos quinze caminhamentos eletromagnéticos (Anexo 2). Na Figura 6.11 o campo eletromagnético indutor é horizontal à superfície, o que garante uma profundidade de investigação de aproximadamente 7,5 m, e na Figura 6.12, o campo eletromagnético é perpendicular à superfície e a profundidade de investigação fica em torno de $15 \mathrm{~m}$ (distância entre o receptor e o transmissor foi fixada em 10 $\mathrm{m})$. Pontos mais condutivos foram registrados em áreas de menores cotas.

\subsubsection{Características físicas e químicas do solo}

A análise táctil-visual das amostras de solo do cemitério mostrou o caráter argiloso deste, com predominância de cores de tons avermelhados. As características físico-químicas determinadas nas 46 amostras são mostradas nas tabelas 6.10 e 6.11. Há um domínio da fração argila (média de $43 \%$ com desvio padrão de 17\%), seguida de areia (média de 35\% com desvio padrão de $7 \%$ ) e silte (média de $20 \%$ com desvio padrão de 13\%). Na fração areia, pode-se observar uma maior quantidade de grãos mais finos, com metade destes entre 0,05 e 0,25 mm. Vinte e oito amostras foram identificadas como de textura argilosa, 7 de franco-argilosa, 5 de franca, 4 de muito argilosa e 2 de argilo-arenosa. $\mathrm{O}$ diâmetro médio dos grãos (média ponderada) é de $0,17 \mathrm{~mm}$ com desvio padrão de $0,06 \mathrm{~mm}$.

Análises químicas de 11 amostras coletadas nas sondagens geológicas (Tabela 6.10) mostram que o solo do cemitério é ácido, com pH em torno de 5,5. As amostras são pobres em matéria orgânica: o valor mais freqüente é $0,7 \%$, sendo o maior valor observado igual a 4,2\%. A capacidade de troca de cátions (CTC) é pequena, variando entre 10,2 e 109,0 mmolc/kg. O Ca é o elemento químico mais expressivo, com um valor médio de 10,6 mmolc/kg, mas variando entre 1 e 35 mmolc/kg, seguido do P (valor médio: 4 mmolc/kg, variando entre 1 e 14 mmolc/kg) e do $\mathrm{Mg}$ (valor médio: $3 \mathrm{mmolc} / \mathrm{kg}$, variando entre 1 e $8 \mathrm{mmolc} / \mathrm{kg}$ ). Mais de $70 \%$ das amostras não apresentaram $\mathrm{Al}$, mas quando presente, o maior valor deste é de $6 \mathrm{mmolc} / \mathrm{kg}$. 


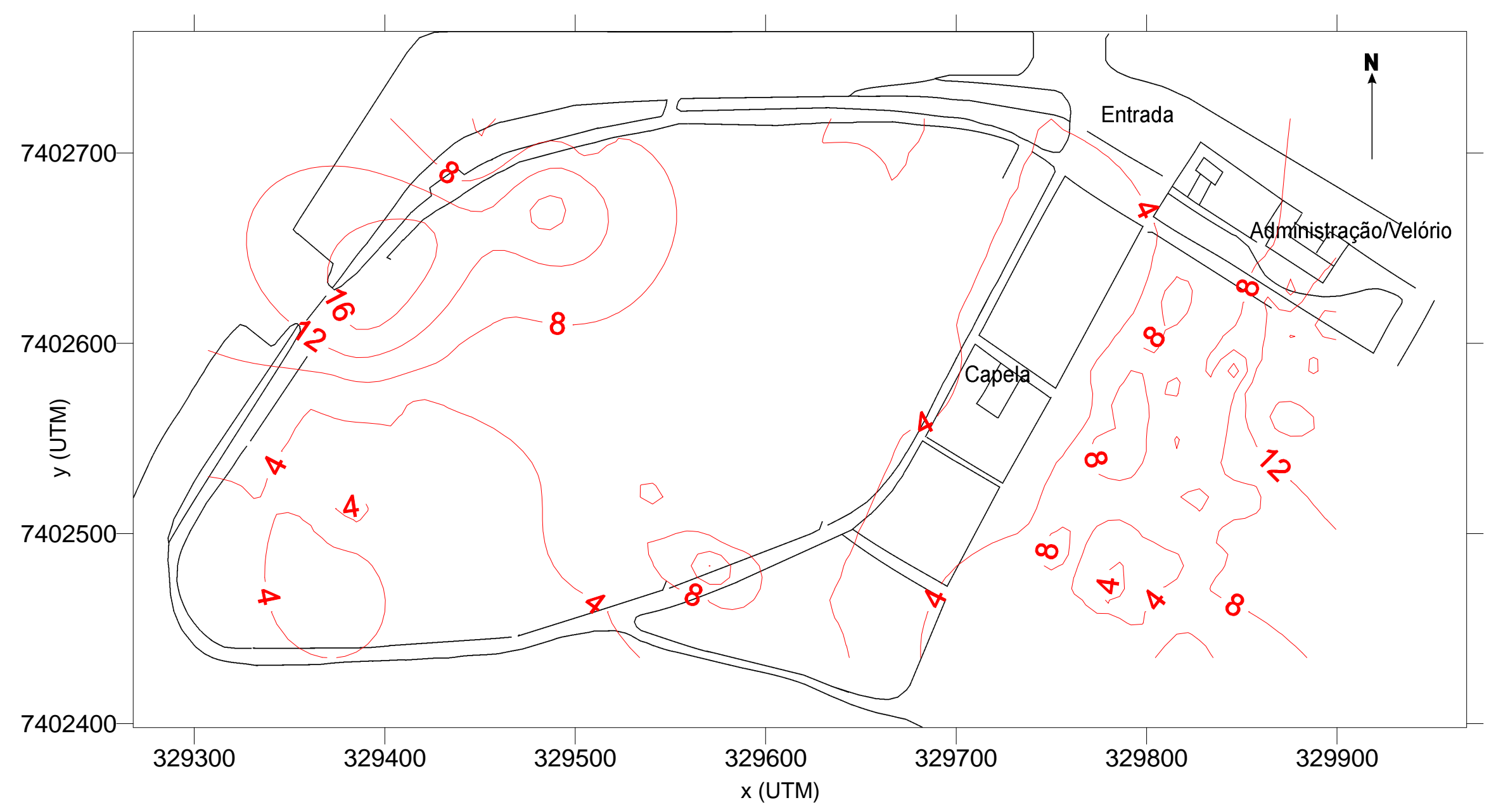

Coordenadas em UTM.Isolinhas a cada $4 \mathrm{mS} / \mathrm{m}$

Figura 6.11 Condutividade elétrica aparente $(\mathrm{mS} / \mathrm{m})$ com campo indutor horizontal 


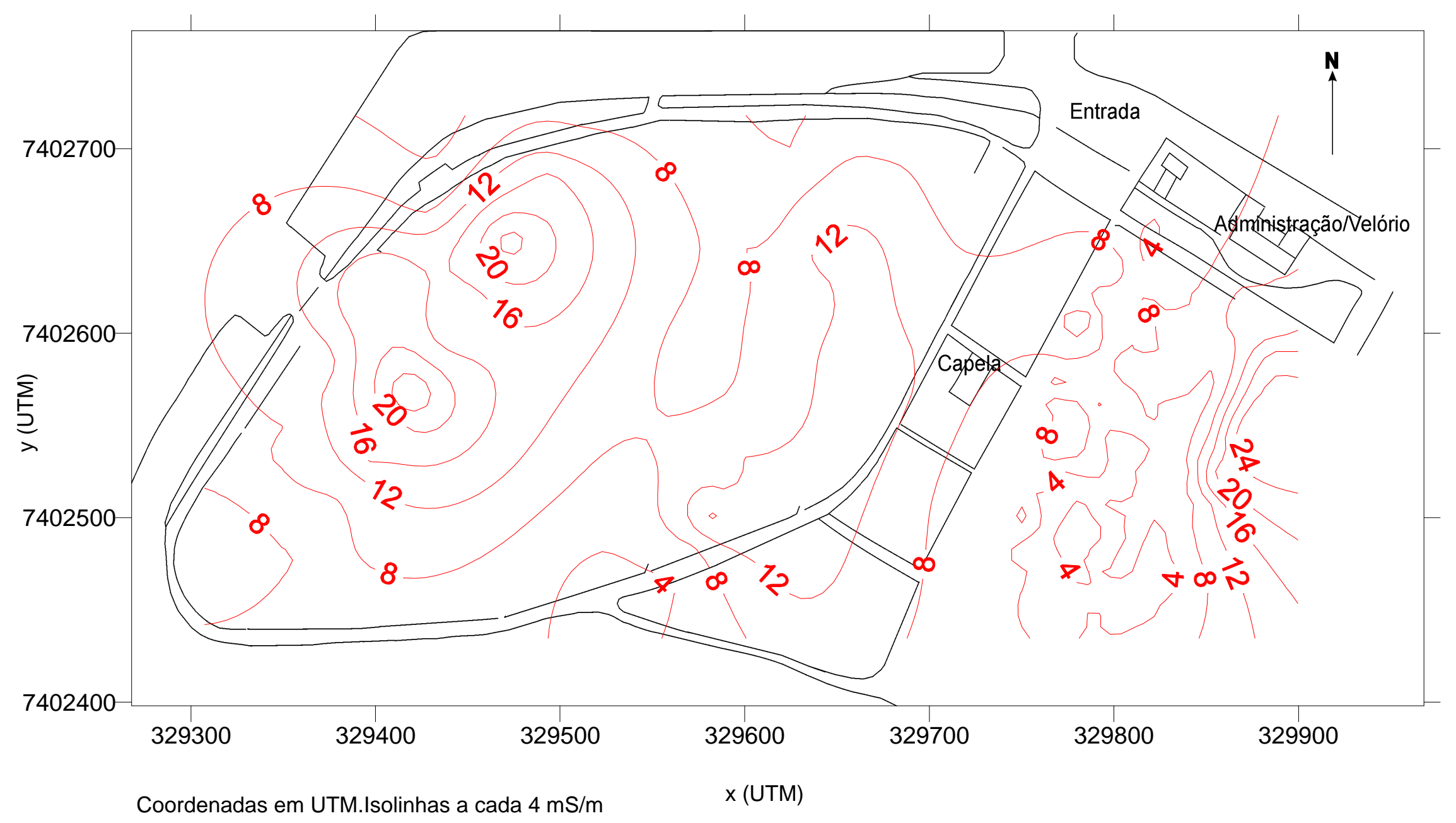

Figura 6.12 Condutividade elétrica aparente $(\mathrm{mS} / \mathrm{m})$ com campo indutor vertical 
Tabela 6.10 Características físico-químicas das amostras de solos das sondagens geológicas

\begin{tabular}{|c|c|c|c|c|c|c|c|c|c|c|c|c|c|c|c|c|c|c|c|}
\hline \multirow[t]{2}{*}{ Parâmetro } & \multicolumn{19}{|c|}{ Amostras de solos } \\
\hline & $\begin{array}{l}\text { ST- } \\
1 / 0\end{array}$ & $\begin{array}{l}\text { ST- } \\
1 / 80\end{array}$ & $\begin{array}{c}\text { ST- } \\
1 / 140\end{array}$ & $\begin{array}{l}\text { ST- } \\
2 / 0\end{array}$ & $\begin{array}{c}\text { ST- } \\
2 / 80\end{array}$ & $\begin{array}{c}\text { ST- } \\
2 / 140\end{array}$ & $\begin{array}{l}\text { ST- } \\
3 / 0\end{array}$ & $\begin{array}{l}\text { ST- } \\
3 / 80\end{array}$ & $\begin{array}{l}\text { ST- } \\
4 / 0\end{array}$ & $\begin{array}{l}\text { ST- } \\
4 / 80\end{array}$ & $\begin{array}{c}\text { ST- } \\
4 / 140\end{array}$ & $\begin{array}{l}\text { ST- } \\
5 / 0\end{array}$ & $\begin{array}{c}\text { ST- } \\
5 / 80\end{array}$ & $\begin{array}{c}\text { ST- } \\
5 / 140\end{array}$ & $\begin{array}{l}\text { ST- } \\
6 / 0\end{array}$ & $\begin{array}{l}\text { ST- } \\
6 / 80\end{array}$ & $\begin{array}{l}\text { ST- } \\
7 / 0\end{array}$ & $\begin{array}{c}\text { ST- } \\
7 / 80\end{array}$ & $\begin{array}{c}\text { ST- } \\
7 / 140\end{array}$ \\
\hline \multicolumn{20}{|l|}{ Frações (\%) } \\
\hline Argila & 54 & 34 & 34 & 46 & 44 & 60 & 54 & 50 & 44 & 34 & 34 & 48 & 38 & 66 & 46 & 40 & 50 & 32 & 57 \\
\hline Silte & 14 & 32 & 30 & 10 & 28 & 10 & 32 & 18 & 20 & 38 & 34 & 18 & 34 & 8 & 21 & 20 & 14 & 32 & 6 \\
\hline \multicolumn{20}{|l|}{ Areia } \\
\hline $0,05-0,10 \mathrm{~mm}$ & 4 & 3 & 3 & 4 & 3 & 3 & 1 & 5 & 3 & 4 & 4 & 3 & 4 & 3 & 4 & 5 & 4 & 5 & 3 \\
\hline 0,10 & 12 & 12 & 9 & 16 & 10 & 11 & 5 & 12 & 14 & 13 & 14 & 14 & 12 & 12 & 12 & 16 & 13 & 14 & 17 \\
\hline $\mathrm{nm}$ & 7 & 8 & 8 & 10 & 6 & 5 & 3 & 6 & 9 & 6 & 7 & 8 & 6 & 5 & 8 & 8 & 7 & 7 & 9 \\
\hline $0,50-$ & 7 & 8 & 12 & 11 & 6 & 7 & 4 & 7 & 8 & 4 & 5 & 7 & 5 & 5 & 7 & 9 & 8 & 8 & 6 \\
\hline $1,00-2$, & 2 & 3 & 4 & 3 & 3 & 4 & 1 & 2 & 2 & 1 & 2 & 2 & 1 & 1 & 2 & 2 & 4 & 2 & 2 \\
\hline Textura & arg. & $\begin{array}{l}\text { fran } \\
\text { arg. }\end{array}$ & $\begin{array}{l}\text { fran } \\
\text { arg. }\end{array}$ & $\sigma$ & rg. & $\begin{array}{l}\mathrm{m} . \\
\text { arg. }\end{array}$ & $\arg$. & rg. & arg. & $\begin{array}{l}\text { fran } \\
\text { arg. }\end{array}$ & $\begin{array}{l}\text { fran } \\
\text { arg. }\end{array}$ & arg. & arg. & $\begin{array}{l}\text { m. } \\
\text { arg. }\end{array}$ & arg. & arg. & arg. & $\begin{array}{l}\text { fran } \\
\text { arg. }\end{array}$ & arg. \\
\hline Diâme & 0,14 & 0,17 & 0,17 & 0,20 & 0,14 & 0,16 & 0,07 & 0,13 & 0,16 & 0,10 & 0,13 & 0,14 & 0,11 & 0,10 & 0,14 & 0,16 & 0,18 & 0,15 & 0,14 \\
\hline $\mathrm{pH}(\mathrm{em}$ & - & - & 5,4 & 6,0 & 5,3 & 5,5 & - & 5,3 & - & - & 5,1 & - & 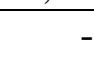 & 5,3 & - & 5,8 & 5,6 & 5,7 & 5,5 \\
\hline Mat. org. (g/kg) & - & - & 7 & 7 & 7 & 7 & - & 10 & - & - & 7 & - & - & 18 & - & 7 & 5 & 10 & 42 \\
\hline $\mathrm{CTC}(\mathrm{mmolc} / \mathrm{kg})$ & - & - & 30,5 & 56,2 & 37,7 & 56,9 & - & 28,2 & - & - & 32,0 & - & - & 61,0 & - & 28,4 & 35,3 & 10,2 & 109,0 \\
\hline $\mathrm{P}(\mathrm{mg} / \mathrm{kg})$ & - & - & 3 & 3 & 2 & 2 & - & 5 & - & - & 2 & - & - & 5 & - & 1 & 2 & 3 & 14 \\
\hline $\mathrm{K}(\mathrm{mmolc} / \mathrm{kg})$ & - & - & 0,5 & 1,2 & 0,7 & 0,9 & - & 1,2 & - & - & 1,0 & - & - & 1,0 & - & 0,4 & 0,3 & 0,2 & 2 \\
\hline $\mathrm{Ca}(\mathrm{m}$ & - & - & 3 & 20 & 13 & 11 & - & 10 & - & - & 4 & - & - & 6 & - & 7 & 7 & 1 & 35 \\
\hline $\operatorname{Mg}($ & - & - & 1 & 5 & 2 & 3 & - & 3 & - & - & 2 & - & - & 3 & - & 1 & 2 & 1 & 8 \\
\hline $\mathrm{Al}(\mathrm{mmolc} / \mathrm{kg})$ & - & - & 6 & 0 & 0 & 0 & - & 0 & - & - & 4 & 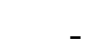 & - & 1 & - & 0 & 0 & 0 & 0 \\
\hline
\end{tabular}

ST-1/0: Amostra da sondagem ST-1 correspondendo a profundidade entre 0 e $20 \mathrm{~cm}$.

ST-7/140: Amostra da sondagem ST-7 correspondendo a profundidade entre 140 e $160 \mathrm{~cm}$.

Diâmetro: diâmetro médio dos grãos; Mat. org.: matéria orgânica; CTC: capacidade de troca de cátions; arg.: argilosa; fran arg.: francoargilosa; m. arg.: muito argilosa; -: não analisado. 
Tabela 6.11 Características físico-químicas das amostras de solos dos poços de monitoração

\begin{tabular}{|c|c|c|c|c|c|c|c|c|c|c|c|c|c|c|}
\hline \multirow[t]{2}{*}{ Parâmetro } & \multicolumn{14}{|c|}{ Amostras de solos } \\
\hline & $\mathrm{P} 5 / 340$ & $\mathrm{P} 5 / 400$ & $\mathrm{P} 6 / 640$ & $\mathrm{P} 6 / 700$ & $\mathrm{P} 7 / 460$ & $\mathrm{P} 7 / 520$ & $\mathrm{P} 8 / 700$ & $\mathrm{P} 8 / 760$ & $\mathrm{P} 10 / 160$ & $\mathrm{P} 10 / 220$ & $\mathrm{P} 10 / 280$ & $\mathrm{P} 10 / 340$ & $\mathrm{P} 10 / 400$ & $\mathrm{P} 10 / 460$ \\
\hline \multicolumn{15}{|c|}{ 20 } \\
\hline Argila & 51 & 31 & 14 & 12 & 54 & 57 & 8 & 10 & 52 & 45 & 37 & 58 & 54 & 63 \\
\hline Silte & 18 & 25 & 40 & 38 & 17 & 12 & 46 & 48 & 20 & 28 & 14 & 9 & 8 & 4 \\
\hline \multicolumn{15}{|l|}{ Areia } \\
\hline $0,05-0,10 \mathrm{~mm}$ & 8 & 9 & 10 & 11 & 4 & 6 & 15 & 13 & 5 & 4 & 6 & 5 & 5 & 5 \\
\hline $0,10-0,25 \mathrm{~mm}$ & 10 & 15 & 11 & 14 & 9 & 8 & 19 & 20 & 8 & 9 & 13 & 9 & 11 & 10 \\
\hline $0,25-0,50 \mathrm{~mm}$ & 7 & 10 & 7 & 8 & 6 & 6 & 10 & 7 & 5 & 6 & 12 & 6 & 8 & 9 \\
\hline $0,50-1,00 \mathrm{~mm}$ & 5 & 8 & 9 & 9 & 7 & 8 & 2 & 2 & 6 & 6 & 13 & 10 & 12 & 8 \\
\hline $1,00-2,00 \mathrm{~mm}$ & 1 & 2 & 9 & 8 & 3 & 2 & 0 & 0 & 2 & 2 & 4 & 3 & 3 & 0 \\
\hline Textura & arg. & fran arg. & fran. & fran. & arg. & arg. & fran. & fran. & arg. & arg. & arg are. & arg. & arg. & m. arg. \\
\hline Diâmetro (mm) & 0,11 & 0,16 & 0,26 & 0,26 & 0,15 & 0,14 & 0,11 & 0,10 & 0,13 & 0,13 & 0,24 & 0,16 & 0,18 & 0,12 \\
\hline $\begin{array}{l}\text { Identificação mineral } \\
\text { da fração argila }\end{array}$ & $\begin{array}{l}\text { ca., gi., } \\
\text { ve. }\end{array}$ & ca., gi. & & & & $\begin{array}{l}\text { ca., gi., } \\
\text { ve. }\end{array}$ & & & ca., gi. & ca., gi. & & $\begin{array}{l}\text { ca., gi., } \\
\text { ve. }\end{array}$ & & \\
\hline \multicolumn{15}{|c|}{$\begin{array}{l}\text { Composição da } \\
\text { fração argila }(\%)\end{array}$} \\
\hline $\mathrm{SiO}_{2}$ & - & - & 38,32 & 39,15 & - & - & 42,44 & 40,84 & - & - & - & - & - & - \\
\hline $\mathrm{Al}_{2} \mathrm{O}_{3}$ & - & - & 34,38 & 33,98 & - & - & 34,66 & 33,83 & - & - & - & - & - & - \\
\hline $\mathrm{MnO}$ & - & - & 0,052 & 0,035 & - & - & 0,055 & 0,395 & - & - & - & - & - & - \\
\hline $\mathrm{MgO}$ & - & - & 0,17 & 0,13 & - & - & 0,31 & 0,47 & - & - & - & - & - & - \\
\hline $\mathrm{CaO}$ & - & - & 0,03 & 0,03 & - & - & 0,05 & 0,04 & - & - & - & - & - & - \\
\hline $\mathrm{Na}_{2} \mathrm{O}$ & - & - & $<0,01$ & $<0,01$ & - & - & $<0,01$ & $<0,01$ & - & - & - & - & - & ( \\
\hline $\mathrm{K}_{2} \mathrm{O}$ & - & - & 0,47 & 0,37 & - & - & 0,56 & 0,48 & - & - & - & - & - & - \\
\hline $\mathrm{TiO}_{2}$ & - & - & 0,994 & 0,603 & - & - & 0,344 & 0,517 & - & - & - & - & - & - \\
\hline $\mathrm{P}_{2} \mathrm{O}_{5}$ & - & - & 0,283 & 0,306 & - & - & 0,455 & 0,352 & - & - & - & - & - & - \\
\hline $\mathrm{Fe}_{2} \mathrm{O}_{3}$ & - & - & 10,94 & 12,31 & - & - & 7,38 & 9,20 & - & - & - & - & - & - \\
\hline Loi & - & - & 14,06 & 13,5 & - & - & 13,69 & 13,84 & - & - & - & - & - & - \\
\hline
\end{tabular}

P5/340: Amostra de solo do poço P5 correspondendo a profundidade entre 340 e $360 \mathrm{~cm}$; Diâmetro: diâmetro médio dos grãos; Loi: queima ao fogo (principalmente água e carbono); arg.: argilosa; fran arg.: franco-argilosa; fran.: franca; arg are.: argilo-arenosa; m. arg.: muito argilosa; ca.: caulinita; gi.: gipsita; ve.: vermiculita. -: não analisado. 
Características físico-químicas das amostras de solos dos poços de monitoração (continuação da Tabela 6.11)

\begin{tabular}{|c|c|c|c|c|c|c|c|c|c|c|c|c|c|}
\hline \multirow[t]{2}{*}{ Parâmetro } & \multicolumn{13}{|c|}{ Amostras de solos } \\
\hline & $\begin{array}{l}\mathrm{P} 13 / 460 \\
\end{array}$ & P14/460 & P15/460 & P16/520 & P17/460 & P19/340 & P19/400 & P19/460 & $\mathrm{P} 19 / 520$ & P19/580 & $\mathrm{P} 20 / 580$ & $\mathrm{P} 20 / 700$ & $\mathrm{P} 20 / 760$ \\
\hline \multicolumn{14}{|l|}{ Frações $(\%)$} \\
\hline Argila & 55 & 52 & 49 & 51 & 50 & 45 & 44 & 50 & 51 & 71 & 28 & 24 & 37 \\
\hline Silte & 9 & 11 & 14 & 12 & 12 & 18 & 17 & 12 & 6 & 7 & 41 & 28 & 14 \\
\hline \multicolumn{14}{|l|}{ Areia } \\
\hline $0,05-0,10 \mathrm{~mm}$ & 6 & 9 & 8 & 7 & 9 & 8 & 8 & 9 & 7 & 6 & 8 & 8 & 9 \\
\hline $0,10-0,25 \mathrm{~mm}$ & 10 & 10 & 9 & 11 & 10 & 12 & 11 & 11 & 13 & 8 & 10 & 13 & 14 \\
\hline $0,25-0,50 \mathrm{~mm}$ & 6 & 7 & 7 & 7 & 8 & 6 & 7 & 5 & 8 & 4 & 6 & 8 & 10 \\
\hline $0,50-1,00 \mathrm{~mm}$ & 6 & 5 & 6 & 7 & 6 & 7 & 10 & 7 & 8 & 3 & 5 & 8 & 9 \\
\hline $1,00-2,00 \mathrm{~mm}$ & 6 & 7 & 7 & 6 & 5 & 4 & 2 & 6 & 8 & 1 & 2 & 12 & 8 \\
\hline Textura & arg. & arg. & arg. & arg. & arg. & arg. & arg. & arg. & arg. & m. arg. & fran arg. & fran & arg are. \\
\hline Diâmetro $(\mathrm{mm})$ & 0,19 & 0,19 & 0,20 & 0,19 & 0,18 & 0,17 & 0,17 & 0,20 & 0,24 & 0,07 & 0,13 & 0,30 & 0,25 \\
\hline $\begin{array}{l}\text { Identificação mineral } \\
\text { da fração argila }\end{array}$ & & $\begin{array}{l}\text { ca., gi., } \\
\text { cl. }\end{array}$ & $\begin{array}{l}\text { ca., gi., } \\
\text { ve., il. }\end{array}$ & $\begin{array}{l}\text { ca., gi., } \\
\text { ve. }\end{array}$ & $\begin{array}{l}\text { ca., gi., } \\
\text { ve., il. }\end{array}$ & $\begin{array}{l}\text { ca., gi., } \\
\text { ve. }\end{array}$ & $\begin{array}{l}\text { ca., gi., } \\
\text { ve. }\end{array}$ & $\begin{array}{l}\text { ca., gi., } \\
\text { ve. }\end{array}$ & $\begin{array}{l}\text { ca., gi., } \\
\text { ve. }\end{array}$ & & $\begin{array}{l}\text { ca., gi., } \\
\text { ve. }\end{array}$ & ca., il. & ca., cli. \\
\hline \multicolumn{14}{|l|}{$\begin{array}{l}\text { Composição da } \\
\text { fração argila (\%) }\end{array}$} \\
\hline $\mathrm{SiO}_{2}$ & - & - & - & - & - & - & - & - & - & - & - & - & 42,81 \\
\hline $\mathrm{Al}_{2} \mathrm{O}_{3}$ & - & - & - & - & - & - & - & - & - & - & - & - & 36,26 \\
\hline $\mathrm{MnO}$ & - & - & - & - & - & - & - & - & - & - & - & - & 0,003 \\
\hline $\mathrm{MgO}$ & - & - & - & - & - & - & - & - & - & - & - & - & 0,10 \\
\hline $\mathrm{CaO}$ & - & - & - & - & - & - & - & - & - & - & - & - & 0,05 \\
\hline $\mathrm{Na}_{2} \mathrm{O}$ & - & - & - & - & - & - & - & - & - & - & - & - & $<0,01$ \\
\hline $\mathrm{K}_{2} \mathrm{O}$ & - & - & - & - & - & - & - & - & - & - & - & - & 0,24 \\
\hline $\mathrm{TiO}_{2}$ & - & - & - & - & - & - & - & - & - & - & - & - & 1,434 \\
\hline $\mathrm{P}_{2} \mathrm{O}_{5}$ & - & - & - & - & - & - & - & - & - & - & - & - & 0,336 \\
\hline $\mathrm{Fe}_{2} \mathrm{O}_{3}$ & - & - & - & - & - & - & - & - & - & - & - & - & 4,45 \\
\hline Loi & - & - & - & - & - & - & - & - & - & - & - & - & 14,04 \\
\hline
\end{tabular}

P13/460: Amostra de solo do poço P13 correspondendo a profundidade entre 460 e $480 \mathrm{~cm}$; Diâmetro: diâmetro médio dos grãos; Loi: queima ao fogo (principalmente água e carbono); arg.: argilosa; m. arg.: muito argilosa; fran arg.: franco-argilosa; fran.: franca; arg are.: argilo-arenosa; ca.: caulinita; gi.: gipsita; cl.: clinocloro; ve.: vermiculita; cli.: clinoclasita; -: não analisado. 
As análises mineralógicas realizadas nas frações de argila de 17 amostras coletadas durante a instalação dos poços de monitoração mostram que estas são formadas principalmente por caulinita e gipsita, apresentando, algumas vezes, vermiculita, ilita, clinocloro e clinoclasita (Tabela 6.11). Análises químicas de cinco amostras das frações de argila (Tabela 6.11) indicam que estas são compostas principalmente por óxidos de sílica $(\sim 41 \%)$, alumínio $(\sim 35 \%)$ e ferro $(\sim 9 \%)$.

A Figura 6.13 resume as informações obtidas das sondagens geofísicas e geológicas e dos poços instalados no cemitério através de um perfil de alteração das rochas. Pouco diferenciado do horizonte B no cemitério de Vila Nova Cachoeirinha, o horizonte A é formado por um solo de cor vermelho-escuro, com espessura variando entre 0,25 e 1,30 m. O horizonte B possui uma espessura aproximada de 5,5 m e é predominantemente formado por argila vermelha-clara. A quantidade de argila presente neste horizonte é bastante variável (de 30 a 60\%), sem uma nítida diferenciação em função do aumento da profundidade. Em geral, depois dos $6 \mathrm{~m}$ de profundidade (horizonte C), há um acréscimo da quantidade de areia e silte, com o decréscimo da fração argila $(\sim 21 \%)$. Neste horizonte, o solo adquire cores como branco, amarelo, rosa e marrom.

\subsubsection{Condutividade hidráulica}

A condutividade hidráulica $K$ foi determinada através de testes tipo slug aplicados nos poços de monitoração. O Anexo 3 mostra os dados observados de campo e a Tabela 6.12 mostra os valores de $K$ em cada poço.

A condutividade hidráulica $K$ varia de $2,90 \times 10^{-8}$ (poço P19) a $8,41 \times 10^{-5} \mathrm{~m} / \mathrm{s}$ (poço P5), com uma média aritmética de $1,32 \times 10^{-5} \mathrm{~m} / \mathrm{s}$. Nos poços P5, P7, P10 e P6 foram observados os maiores valores de $\mathrm{K}$ (ordem de $10^{-5} \mathrm{~m} / \mathrm{s}$ ), enquanto os poços P12, P13, P15, P16 e P19 apresentaram os menores valores (ordem de $10^{-8} \mathrm{~m} / \mathrm{s}$ ). 


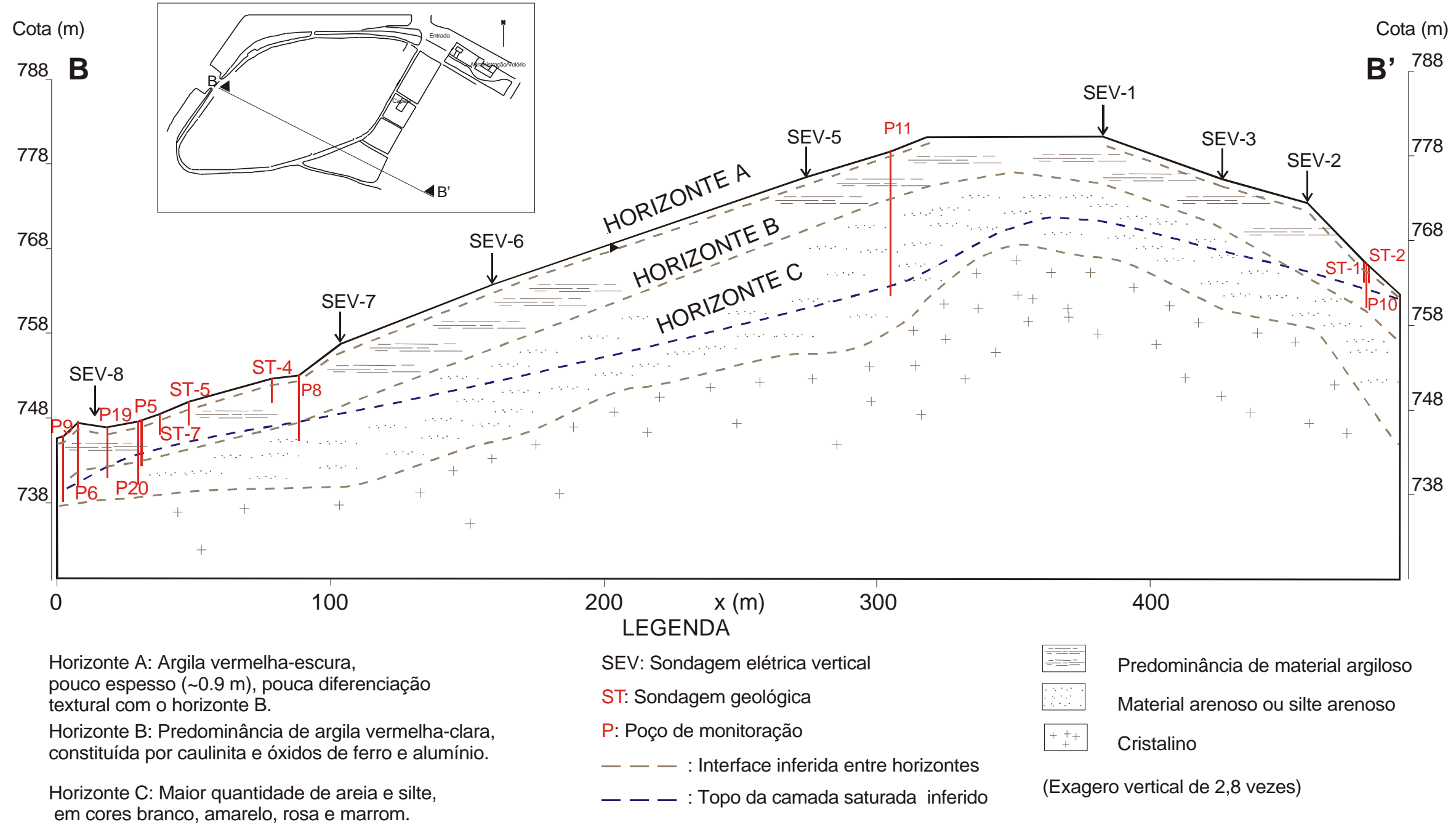

Figura 6.13 Perfil de alteração das rochas no cemitério 
Tabela 6.12 Condutividade hidráulica $K$ determinada nos testes tipo slug

\begin{tabular}{cc}
\hline Poço & Condutividade hidráulica $K(\mathrm{~m} / \mathrm{s})$ \\
\hline P1 & $5,61 \mathrm{E}-6$ \\
P2 & $6,55 \mathrm{E}-7$ \\
P3 & $1,97 \mathrm{E}-6$ \\
P4 & $2,01 \mathrm{E}-6$ \\
P5 & $8,41 \mathrm{E}-5$ \\
P6 & $1,87 \mathrm{E}-5$ \\
P7 & $4,81 \mathrm{E}-5$ \\
P8 & $2,90 \mathrm{E}-6$ \\
P9 & $5,61 \mathrm{E}-6$ \\
P10 & $2,85 \mathrm{E}-5$ \\
P12 & $6,87 \mathrm{E}-8$ \\
P13 & $4,03 \mathrm{E}-8$ \\
P15 & $7,11 \mathrm{E}-8$ \\
P16 & $7,48 \mathrm{E}-8$ \\
P19 & $2,90 \mathrm{E}-8$ \\
\hline$n$ & 15 \\
$\bar{X}$ & $1,32 \mathrm{E}-5$ \\
$s$ & $2,39 \mathrm{E}-5$ \\
$x_{\min }$ & $2,90 \mathrm{E}-8$ \\
$x_{\max }$ & $8,41 \mathrm{E}-5$ \\
\hline
\end{tabular}

$n$ : número de observações; $\bar{X}:$ média aritmética; $s$ : desvio padrão;

$x_{\min }$ : valor mínimo observado; $x_{\max }$ : valor máximo observado.

\subsubsection{Fluxo das águas subterrâneas}

No cemitério de Vila Nova Cachoeirinha, o topo do morro corresponde ao divisor de águas, onde o fluxo divide-se em direção ao rio Cabuçu de Baixo e ao córrego que atravessa o cemitério. A Tabela 6.13 mostra um resumo das observações de nível d'água nos poços de monitoração, sendo utilizadas para calcular as cargas hidráulicas ao longo do tempo. As menores cargas foram observadas em novembro de 1999 e as maiores em março de 2000, com uma variação média de 1,4 m. A Figura 6.14 mostra a variação do nível d'água no poço P1 ao longo do tempo e a chuva $(\mathrm{mm})$ diária estimada a partir do posto pluviométrico de Santana (Código: E3-071).

O mapa potenciométrico de março de 2000 (Figura 6.15) mostra que na porção oeste do cemitério a carga hidráulica varia de $762 \mathrm{~m}$, próximo ao topo, até $742 \mathrm{~m}$, nas menores cotas, o que nos dá um gradiente hidráulico de aproximadamente $0,07 \mathrm{~m} / \mathrm{m}$. 
Tabela 6.13 Nível d'água observado nos poços

\begin{tabular}{|c|c|c|c|c|c|c|c|c|c|c|c|}
\hline \multirow[t]{2}{*}{ Poço } & \multirow[t]{2}{*}{$n$} & \multicolumn{4}{|c|}{ Nível d'água (m) } & \multirow[t]{2}{*}{ Poço } & \multirow[t]{2}{*}{$n$} & \multicolumn{4}{|c|}{ Nível d'água (m) } \\
\hline & & $\bar{X}$ & $s$ & $x_{\min }$ & $x_{\max }$ & & & $\bar{X}$ & $s$ & $x_{\min }$ & $x_{\max }$ \\
\hline $\mathrm{P} 1$ & 26 & 2,94 & 0,73 & 1,97 & $>4,90$ & $\mathrm{P} 11$ & 4 & 16,85 & 0,3 & 16,53 & $>17,15$ \\
\hline $\mathrm{P} 2$ & 28 & 3,98 & 0,19 & 3,71 & 4,39 & $\mathrm{P} 12$ & 6 & 4,53 & 0,18 & 4,29 & $>5,0$ \\
\hline P3 & 28 & 4,12 & 0,26 & 3,63 & 4,57 & P13 & 14 & 4,11 & 0,18 & 3,58 & 4,3 \\
\hline P4 & 27 & 2,47 & 0,17 & 2,17 & 2,90 & $\mathrm{P} 14$ & 1 & 4,31 & & & \\
\hline P5 & 10 & 4,60 & 0,51 & 4,25 & 5,68 & $\mathrm{P} 15$ & 13 & 2,72 & 0,44 & 1,92 & 3,32 \\
\hline P6 & 10 & 6,29 & 0,81 & 5,10 & 7,30 & $\mathrm{P} 16$ & 9 & 3,37 & 0,6 & 2,85 & $>4,84$ \\
\hline P7 & 7 & 4,23 & 0,76 & 3,11 & 5,22 & $\mathrm{P} 17$ & 8 & 4,56 & 0,26 & 4,08 & $>4,84$ \\
\hline P8 & 10 & 5,70 & 0,66 & 4,75 & 6,42 & P18 & 1 & 4,32 & & & \\
\hline P9 & 9 & 5,17 & 0,67 & 4,13 & 5,87 & P19 & 14 & 4,59 & 0,63 & 3,70 & 5,39 \\
\hline P10 & 9 & 3,43 & 0,94 & 2,01 & 4,84 & P20 & 11 & 4,57 & 0,98 & 4,00 & 5,49 \\
\hline
\end{tabular}

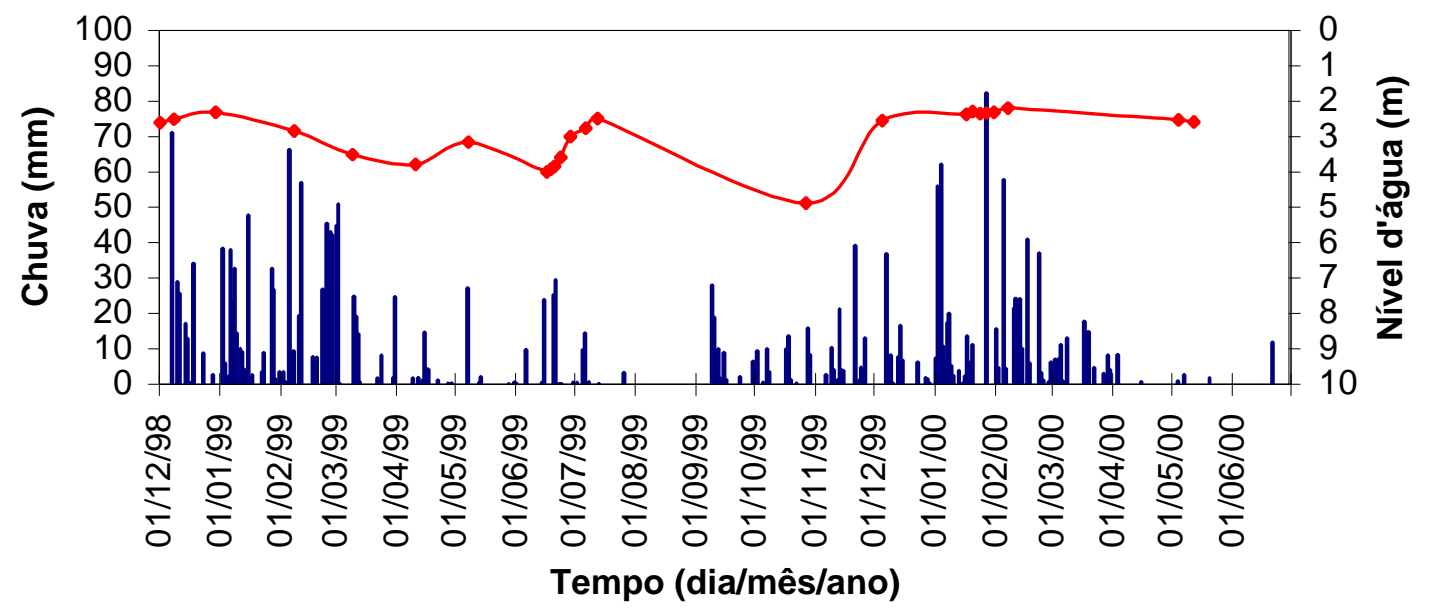

Chuva (mm) $\rightarrow$ Nível d'água (m)

Figura 6.14 Chuva diária (mm) e nível d'água $(\mathrm{m})$ no poço P1 Obs.: Precipitação do posto pluviométrico de Santana (Código: E3-071). 


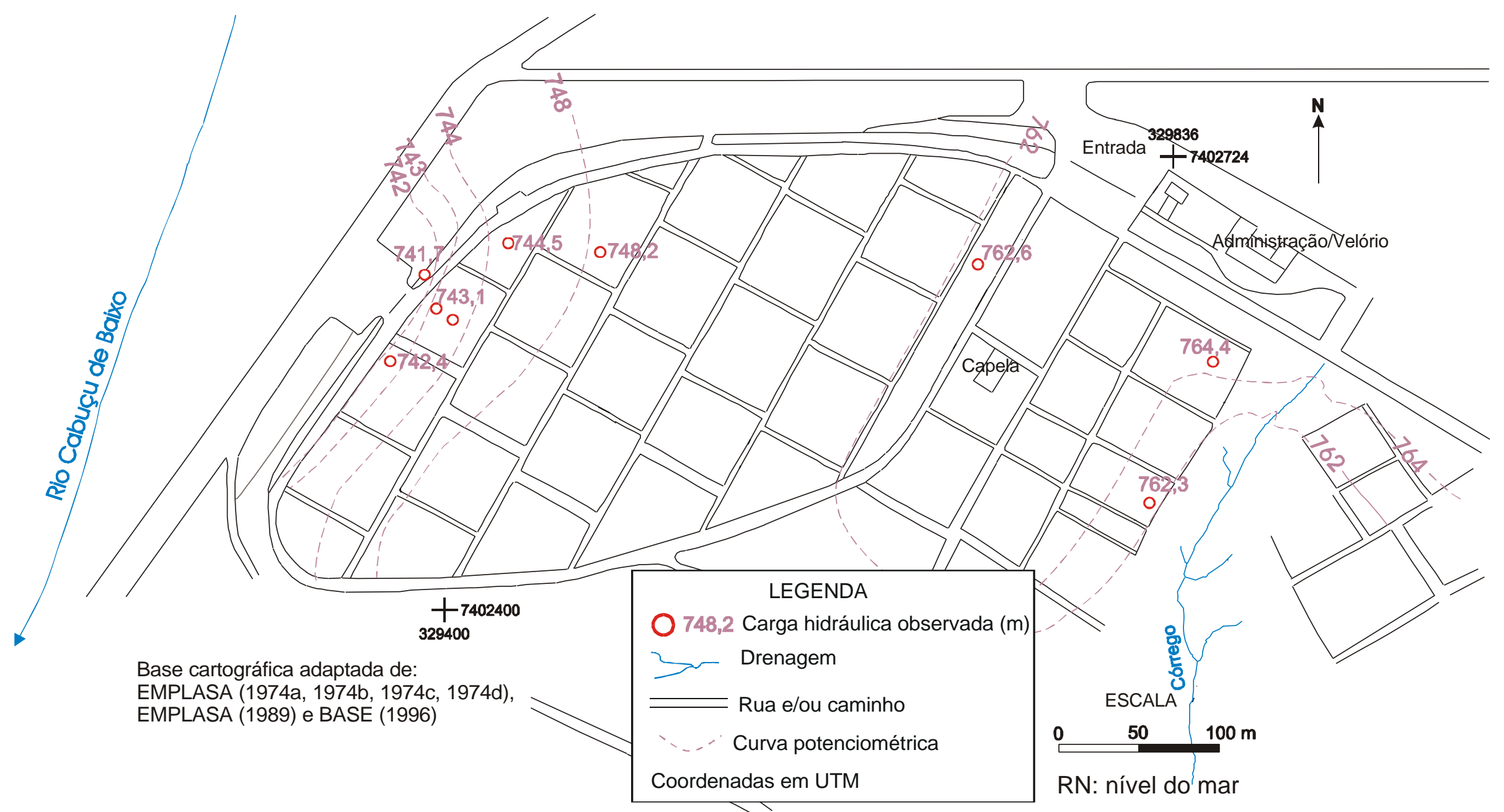

Figura 6.15 Mapa potenciométrico (março de 2000) 


\subsubsection{Injeção do traçador}

A Figura 6.16 mostra a concentração relativa observada ao longo do tempo no poço P2, a jusante do poço injetor P1. Um modelo numérico foi ajustado aos dados, considerando a injeção pontual do traçador químico, de forma semelhante aos trabalhos na coluna de solo. A dispersividade $\alpha$ foi estimada pelo modelo em $0,2 \mathrm{~m}$.

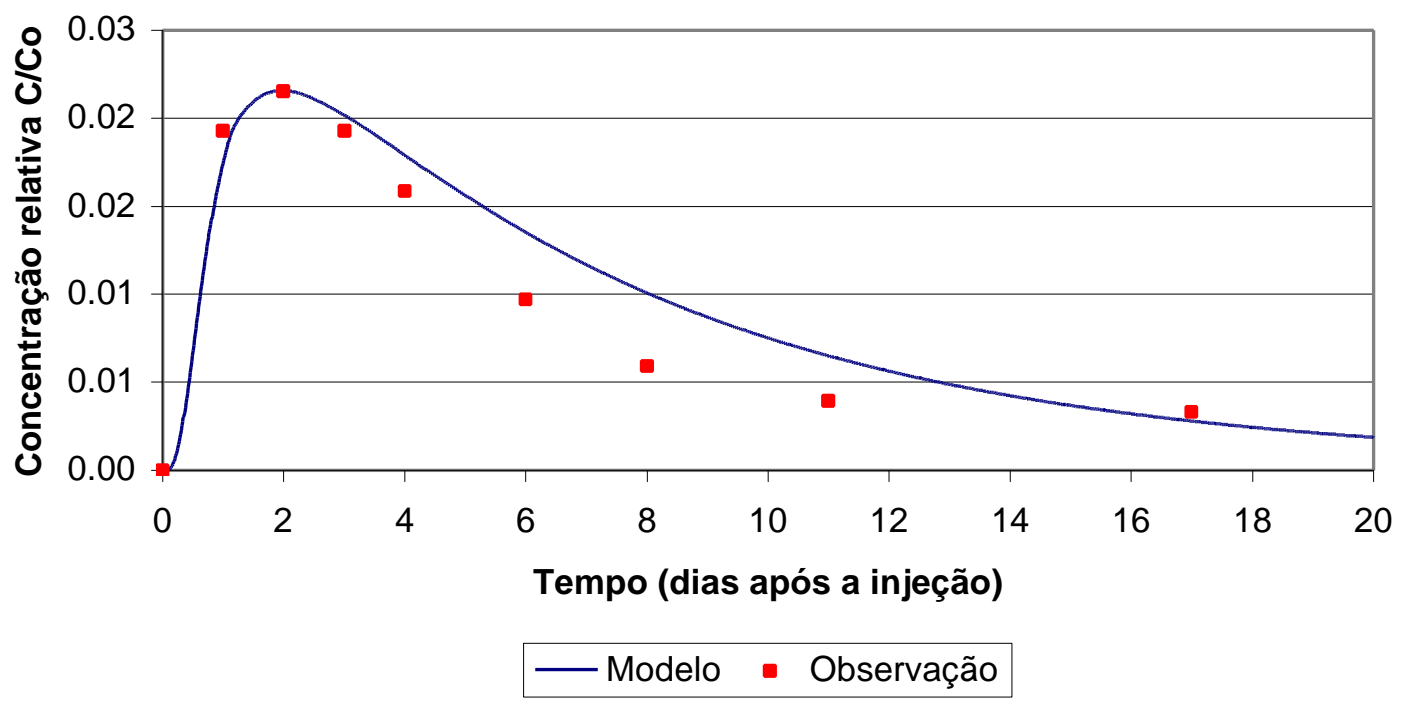

Figura 6.16 Concentração relativa $\left(C / C_{0}\right)$ observada e modelo ajustado no poço $\mathrm{P} 2$

Considerando o gradiente hidráulico determinado de $0,07 \mathrm{~m} / \mathrm{m}$ e o valor médio de condutividade hidráulica de 1,32E-5 m/s, a velocidade de Darcy $q$ é dada por 9,2E-7 m/s na porção oeste do cemitério. A porosidade efetiva $n_{e}$ foi estimada em $2 \%$, a partir dos valores sugeridos por REBOUÇAS \& CAVALCANTE (1987) apud MENEGASSE (1991) que citam porosidade efetiva $n_{e}$ entre 0,1 e $2,0 \%$ para o terço superior do aqǘfero cristalino; por MENEGASSE VELASQUEZ (1996) que menciona 3\% no estudo desenvolvido pelo Centro de Pesquisa de Águas Subterrâneas (CEPAS), e pelos trabalhos em lâminas, de amostras indeformadas de solo do cemitério de Vila Nova Cachoeirinha, realizados por TÔRRES (1992a), que calcula valores entre 9,8 e 2,12\% (porosidade diminuindo com o aumento da profundidade). Desta forma, a velocidade linear média é dada por aproximadamente $8 \mathrm{~cm} /$ dia. 


\subsubsection{Indicadores químicos}

A Tabela 6.14 mostra os valores médio, mínimo e máximo observados de temperatura, $\mathrm{pH}$, potencial redox, condutividade elétrica, oxigênio dissolvido e alcalinidade. A temperatura média das águas é de $23^{\circ} \mathrm{C}$. As águas do cemitério possuem um $\mathrm{pH}$ médio de 6,1 , mas as águas dos poços P6, P8 e P11 apresentam um pH menor $(\sim 5,4)$. Os resultados de potencial redox (Eh) são bastante variáveis (-225 a $350 \mathrm{mV}$ ), notando-se um ambiente redutor na maioria dos poços, sendo que os poços P6 e P8 apresentam um caráter oxidante. A condutividade elétrica das águas pode atingir $600 \mu \mathrm{S} / \mathrm{cm}$ em alguns poços, mas nos P6 e P11 não passa de $100 \mu \mathrm{S} / \mathrm{cm}$, e no P8, dificilmente passa de $200 \mu \mathrm{S} / \mathrm{cm}$. A quantidade de oxigênio dissolvido nas águas é de aproximadamente 1,6 mg/L, mas os poços P6 e P8 possuem, em média, 3,2 mg/L. A alcalinidade

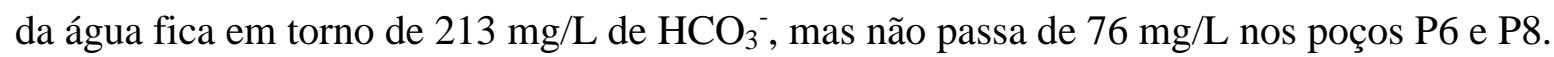

A Tabela 6.15 mostra os resultados das análises químicas. Apenas as amostras dos poços P5, P6, P8 e P10 satisfizeram o balanço iônico, com afastamento entre cátions e ânions de até 10\%. De acordo com a tabela, o ânion predominante é o $\mathrm{HCO}_{3}{ }^{-}$, sendo que este é bem mais expressivo nos poços P5 e P10 (> $100 \mathrm{mg} / \mathrm{L})$; nos poços P6 e P8, esta quantidade é menor (< 40 $\mathrm{mg} / \mathrm{L})$. O segundo ânion mais expressivo é o $\mathrm{Cl}^{-}(\sim 11 \mathrm{mg} / \mathrm{L})$ nos poços $\mathrm{P} 5$ e $\mathrm{P} 10$ e o $\mathrm{NO}_{3}{ }^{-}$nos P6 e P8 (11,56 e 21,62 mg/L, respectivamente). Sódio e cálcio são os cátions predominantes, sendo que os P5 e P10 também apresentam quantidades maiores destes elementos $(11,8-30 \mathrm{mg} / \mathrm{L})$, quando comparados com os P6 e P8 $(<5 \mathrm{mg} / \mathrm{L})$. As águas dos poços P5 e P10 possuem mais ferro, alumínio, chumbo e zinco do que os P6 e P8, como mostra a referida tabela.

A Tabela 6.16 mostra os íons maiores em percentagem de meq/L. Esta tabela foi utilizada para a confecção do diagrama de Piper (Figura 6.17) e classificação das águas. De acordo com o diagrama de Piper, as águas dos poços P5, P6 e P8 são bicarbonatadas sódicas, sendo que as amostras do P5 (11/1999) e do P10 são bicarbonatadas cálcicas. 
Tabela 6.14 Resultados dos indicadores químicos medidos in situ

\begin{tabular}{|c|c|c|c|c|c|c|c|c|c|c|c|c|c|c|c|c|c|c|c|c|c|c|c|c|}
\hline \multirow[t]{2}{*}{ Poço } & \multicolumn{4}{|c|}{$\begin{array}{c}\mathrm{T} \\
\left({ }^{\circ} \mathrm{C}\right) \\
\end{array}$} & \multicolumn{4}{|c|}{$\mathrm{pH}$} & \multicolumn{4}{|c|}{$\begin{array}{c}\mathrm{Eh} \\
(\mathrm{mV})\end{array}$} & \multicolumn{4}{|c|}{$\begin{array}{c}\text { Cond. Elétrica } \\
(\mu \mathrm{S} / \mathrm{cm})\end{array}$} & \multicolumn{4}{|c|}{$\begin{array}{c}\mathrm{O}_{2} \\
(\mathrm{mg} / \mathrm{L})\end{array}$} & \multicolumn{4}{|c|}{$\begin{array}{c}\text { Alcalinidade } \\
\left.\left(\mathrm{mg} / \mathrm{L} \mathrm{HCO}_{3}\right)^{-}\right)\end{array}$} \\
\hline & $n$ & $\bar{X}$ & $x_{\min }$ & $x_{\max }$ & $n$ & $\bar{X}$ & $x_{\min }$ & $x_{\max }$ & $n$ & $\bar{X}$ & $x_{\min }$ & $x_{\max }$ & $n$ & $\bar{X}$ & $x_{\min }$ & $x_{\max }$ & $n$ & $\bar{X}$ & $x_{\text {min }}$ & $x_{\max }$ & $n$ & $\bar{X}$ & $x_{\text {min }}$ & $x_{\max }$ \\
\hline P1 & 12 & 23 & 21,0 & 25,6 & 13 & 6,6 & 6,08 & 6,85 & 13 & -90 & -136 & 56 & 12 & 616 & 516 & 666 & 7 & 1,4 & 0,81 & 2,90 & 1 & 370 & & \\
\hline P2 & 14 & 23 & 21,3 & 26,5 & 15 & 6,6 & 6,44 & 6,80 & 15 & -60 & -146 & 8 & 15 & 527 & 455 & 652 & 9 & 1,6 & 0,85 & 3,40 & 2 & 228 & 196 & 261 \\
\hline P3 & 12 & 23 & 21,5 & 24,9 & 13 & 6,7 & 6,48 & 6,84 & 13 & -110 & -164 & -67 & 13 & 528 & 424 & 594 & 8 & 1,0 & 0,21 & 1,51 & 1 & 261 & & \\
\hline P4 & 14 & 23 & 20,8 & 25,7 & 15 & 6,7 & 6,61 & 6,84 & 15 & -120 & -171 & -80 & 15 & 592 & 544 & 621 & 11 & 1,1 & 0,34 & 2,46 & 2 & 335 & 332 & 337 \\
\hline P5 & 8 & 23 & 20,8 & 25,5 & 8 & 6,2 & 6,02 & 6,34 & 8 & -15 & -68 & 33 & 8 & 369 & 252 & 485 & 7 & 2,0 & 0,80 & 4,70 & 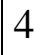 & 159 & 44 & 265 \\
\hline P6 & 8 & 23 & 20,5 & 23,6 & 8 & 4,8 & 4,47 & 5,46 & 8 & 200 & -226 & 350 & 8 & 55 & 42,4 & 85,4 & 7 & 3,5 & 2,90 & 3,93 & 4 & 30 & $<10$ & 76 \\
\hline P7 & 8 & 23 & 20,0 & 24,9 & 8 & 6,2 & 5,81 & 6,65 & 8 & -60 & -83 & -36 & 8 & 344 & 280 & 409 & 6 & 2,4 & 0,09 & 5,93 & 4 & 184 & 130 & 151 \\
\hline P8 & 9 & 23 & 20,7 & 25,2 & 9 & 5,0 & 4,59 & 5,51 & 9 & 180 & 66 & 305 & 9 & 181 & 65 & 305 & 8 & 2,8 & 1,83 & 3,78 & 5 & 20 & $<10$ & 34 \\
\hline P9 & 8 & 23 & 21,0 & 25,2 & 8 & 6,4 & 6,24 & 6,49 & 8 & -50 & -78 & -25 & 8 & 477 & 286 & 577 & 7 & 1,7 & 0,27 & 7,00 & 4 & 257 & 199 & 305 \\
\hline P10 & 8 & 23 & 18,8 & 25,2 & 8 & 6,0 & 5,85 & 6,41 & 8 & -10 & -38 & 32 & 8 & 237 & 186 & 280 & 6 & 2,3 & 0,12 & 6,65 & 4 & 140 & 109 & 188 \\
\hline P11 & 1 & 24 & & & 1 & 5,8 & & & 1 & 1 & & & 1 & 80 & & & 0 & & & & 0 & & & \\
\hline P12 & 10 & 23 & 18,5 & 27,0 & 2 & 5,5 & 4,57 & 6,37 & 2 & 120 & 21 & 229 & 10 & 285 & 240 & 378 & 1 & 0,6 & & & 0 & & & \\
\hline P13 & 15 & 23 & 19,9 & 27,0 & 5 & 6,6 & 6,60 & 6,69 & 5 & -110 & -174 & -50 & 15 & 586 & 503 & 627 & 4 & 0,4 & 0,20 & 0,70 & & 261 & & \\
\hline P15 & 15 & 23 & 19,0 & 27,6 & 8 & 6,5 & 6,17 & 6,75 & 8 & -60 & -147 & 30 & 15 & 320 & 213 & 610 & 8 & 1,0 & 0,30 & 2,27 & 2 & 258 & 250 & 266 \\
\hline P16 & 11 & 22 & 18,7 & 27,8 & 4 & 6,1 & 5,72 & 6,77 & 4 & -30 & -134 & 69 & 11 & 264 & 157 & 622 & 4 & 1,3 & 0,32 & 2,00 & J & & & \\
\hline P17 & 4 & 22 & 22,2 & 23,1 & 2 & 5,9 & 5,88 & 6,00 & 2 & 10 & -29 & 47 & 4 & 246 & 163 & 287 & 1 & 1,3 & & & 0 & & & \\
\hline P19 & 11 & 23 & 18,7 & 28,9 & 5 & 6,3 & 6,22 & 6,59 & 5 & 1 & -87 & 60 & 11 & 466 & 400 & 521 & 4 & 1,4 & 0,40 & 1,90 & 2 & 154 & 44 & 265 \\
\hline $\mathrm{P} 20$ & 6 & 23 & 21,6 & 26,2 & 4 & 6,6 & 6,38 & 6,77 & 4 & -85 & -134 & -50 & 6 & 606 & 521 & 652 & 4 & 1,3 & 0,32 & 2,23 & 2 & 321 & 283 & 359 \\
\hline$n$ & & 18 & & & & 18 & & & & 18 & & & & 18 & & & & 17 & & & & 14 & & \\
\hline $\bar{X}$ & & 23 & & & & 6,1 & & & & -16 & & & & 377 & & & & 1,6 & & & & 213 & & \\
\hline$s$ & & 0,4 & & & & 0,6 & & & & 94 & & & & 181 & & & & 0,8 & & & & 105 & & \\
\hline
\end{tabular}

$n$ : número de observações; $\bar{X}$ : média aritmética; $s$ : desvio padrão; $x_{\min }$ : valor mínimo observado; $x_{\max }$ : valor máximo observado. 
Tabela 6.15 Resultados das análises químicas

\begin{tabular}{|c|c|c|c|c|c|c|}
\hline \multirow{2}{*}{$\begin{array}{c}\text { Elemento } \\
(\mathrm{mg} / \mathrm{L})\end{array}$} & \multicolumn{6}{|c|}{ Poço (data da coleta) } \\
\hline & P5(01/9/99) & P5(28/11/99) & P6(28/11/99) & P8(28/11/99) & P8(21/3/00) & P10(26/10/99) \\
\hline $\mathrm{Na}^{+}$ & 27,5 & 11,8 & 4,8 & 3,9 & 4,2 & 5,8 \\
\hline $\mathrm{K}^{+}$ & 4,0 & 4,3 & 6,0 & 3,6 & 1,7 & 6,9 \\
\hline $\mathrm{Ca}^{2+}$ & 20,8 & 30 & 3,9 & 3,8 & 0,42 & 34,4 \\
\hline $\mathrm{Mg}^{2+}$ & 7,7 & 4,7 & 1,0 & 2,8 & 2,2 & 3,7 \\
\hline $\mathrm{Fe}^{\text {total }}$ & 35,73 & 19,84 & 7,56 & 1,07 & 1,7 & 81,3 \\
\hline $\mathrm{Mn}^{2+}$ & 0,53 & 0,80 & 0,62 & 0,45 & 0,11 & 4,24 \\
\hline $\mathrm{Al}^{3+}$ & 5,46 & 9,35 & 3,13 & 4,59 & $3 *$ & 33,59 \\
\hline $\mathrm{Ba}^{2+}$ & 0,3 & 0,41 & 0,29 & 0,46 & - & 0,57 \\
\hline $\mathrm{Sr}^{2+}$ & 0,10 & 0,11 & 0,01 & 0,03 & - & 0,24 \\
\hline $\mathrm{Ni}^{2+}$ & n.d. & n.d. & n.d. & n.d. & - & 0,02 \\
\hline $\mathrm{Pb}^{2+}$ & 0,62 & n.d. & 0,29 & 0,34 & - & 0,38 \\
\hline $\mathrm{Cu}^{2+}$ & 0,06 & 0,05 & 0,02 & 0,02 & - & 0,01 \\
\hline $\mathrm{Zn}^{2+}$ & 0,49 & 0,29 & 0,19 & 0,08 & - & 1,54 \\
\hline $\mathrm{Ag}^{+}$ & n.d. & n.d. & n.d. & n.d. & - & n.d. \\
\hline $\mathrm{Cd}^{2+}$ & n.d. & n.d. & n.d. & n.d & - & n.d. \\
\hline $\mathrm{Cr}^{\text {total }}$ & 0,01 & n.d. & 0,01 & 0,02 & - & n.d. \\
\hline $\mathrm{F}^{-}$ & 0,11 & 0,620 & 0,010 & 0,014 & 0,14 & 0,16 \\
\hline $\mathrm{Cl}^{-}$ & 10,4 & 12,33 & 1,93 & 2,35 & 3,5 & 6,23 \\
\hline $\mathrm{NO}_{2}^{-}$ & n.d. & n.d. & n.d. & n.d & 0,4 & n.d. \\
\hline $\mathrm{Br}^{-}$ & 0,50 & 0,06 & 0,04 & 0,22 & - & 0,80 \\
\hline $\mathrm{NO}_{3}{ }^{-}$ & 0,65 & 0,03 & 11,56 & 21,62 & 0,08 & n.d. \\
\hline $\mathrm{PO}_{4}{ }^{3-}$ & 0,06 & 0,060 & 0,013 & 0,009 & & 0,11 \\
\hline $\mathrm{SO}_{4}{ }^{2-}$ & 11,49 & 30,14 & 0,85 & 0,5 & 7 & 2,63 \\
\hline $\mathrm{HCO}_{3}{ }^{-}$ & 188 & 120 & 34 & 34 & 11 & 109 \\
\hline
\end{tabular}


Tabela 6.16 Cátions e ânions maiores em \% de meq/L e classificação

\begin{tabular}{c|ccc|ccc|c}
\hline Poço & \multicolumn{3}{|c|}{ Cátions (\% de meq/L) } & \multicolumn{3}{|c|}{$\hat{\mathrm{Anions} \mathrm{( \%} \mathrm{de} \mathrm{meq/L)}}$} & Classificação \\
& $\mathrm{Na}^{+}+\mathrm{K}^{+}$ & $\mathrm{Ca}^{2+}$ & $\mathrm{Mg}^{2+}$ & $\mathrm{Cl}^{-}+\mathrm{NO}_{3}^{2-}$ & $\mathrm{SO}_{4}{ }^{2-}$ & $\mathrm{HCO}_{3}{ }^{-}$ & \\
\hline P5 (09/1999) & 44 & 35 & 21 & 8 & 7 & 85 & bicarbonatada sódica \\
P5 (11/1999) & 25 & 60 & 15 & 12 & 21 & 67 & bicarbonatada cálcica \\
P6 (11/1999) & 57 & 30 & 13 & 30 & 2 & 68 & bicarbonatada sódica \\
P8 (11/1999) & 38 & 28 & 34 & 42 & 1 & 57 & bicarbonatada sódica \\
P8 (03/2000) & 53 & 5 & 42 & 24 & 34 & 42 & bicarbonatada sódica \\
P10 (10/1999) & 18 & 70 & 12 & 9 & 3 & 88 & bicarbonatada cálcica \\
\hline
\end{tabular}

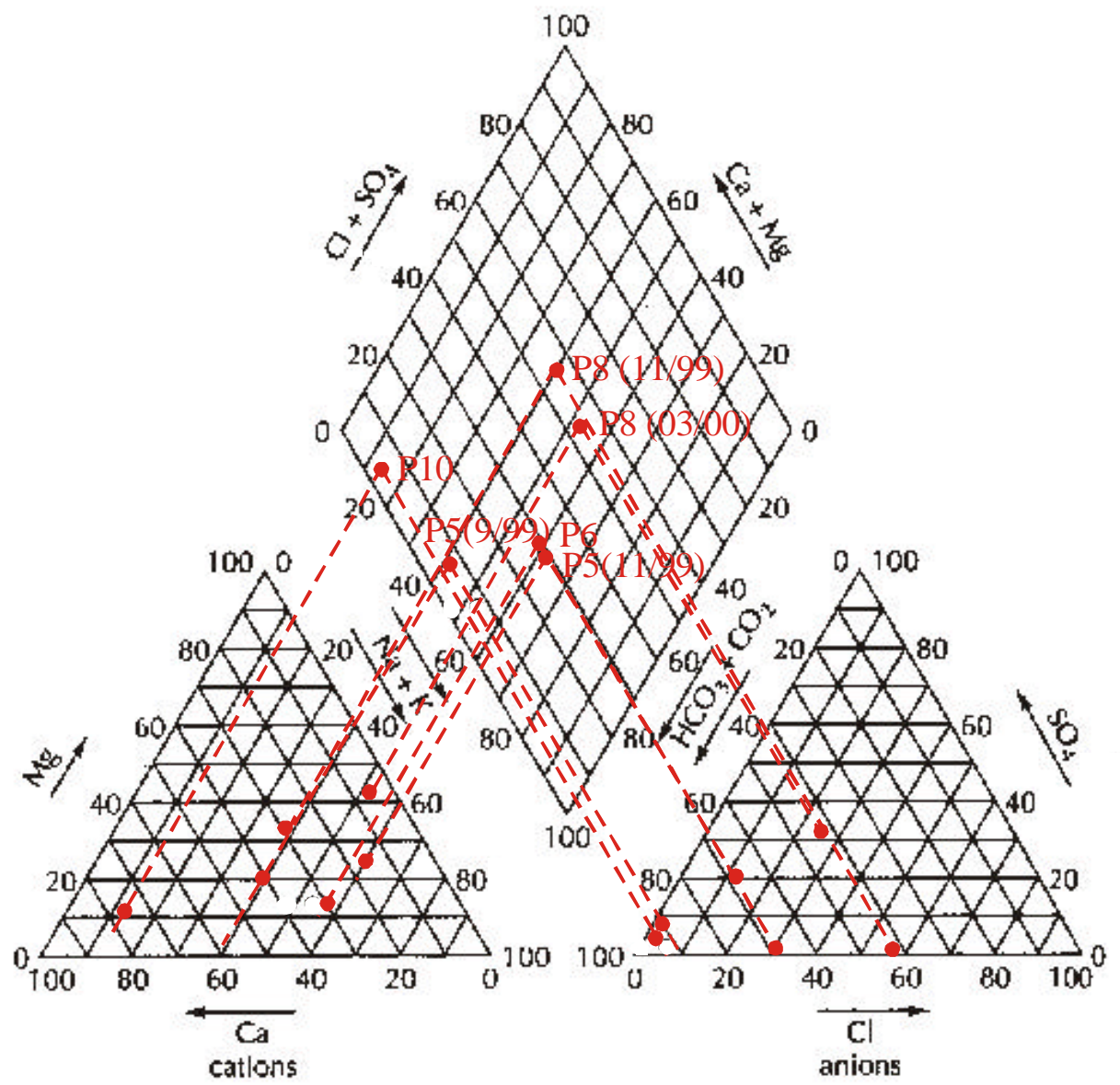

Figura 6.17 Diagrama de Piper 


\subsubsection{Indicadores microbiológicos}

A Tabela 6.17 mostra a média geométrica, os valores máximo e mínimo observados de bactérias heterotróficas, coliformes totais e fecais, bactérias proteolíticas e clostrídios sulfitoredutores nas amostras de água subterrânea do cemitério de Vila Nova Cachoeirinha.

O número de bactérias heterotróficas varia de 120 a $40 \times 10^{5} \mathrm{UFC} / \mathrm{mL}$, sendo maior nos poços P5 (média geométrica de $130 \times 10^{3} \mathrm{UFC} / \mathrm{mL}$ ) e P7 (média geométrica de $280 \times 10^{3}$ $\mathrm{UFC} / \mathrm{mL}$ ). O número de coliformes totais varia de menor que $2 \mathrm{NMP} / 100 \mathrm{~mL}$ a maior ou igual a $1.600 \mathrm{NMP} / 100 \mathrm{~mL}$ (valor observado nos poços P7 e P9). Os poços P5 e P9 apresentam as maiores médias geométricas de coliformes totais $(75$ e $69 \mathrm{NMP} / 100 \mathrm{~mL}$, respectivamente). O número de coliformes fecais varia de menor que $2 \mathrm{NMP} / 100 \mathrm{~mL}$ a maior ou igual a 1.600 NMP/100 mL (valor observado no poço P7). O poço P9 chegou a ter um número de coliformes fecais de $300 \mathrm{NMP} / 100 \mathrm{~mL}$. O número de bactérias proteolíticas varia de menor que $2 \mathrm{NMP} / 100$ $\mathrm{mL}$ a maior ou igual a $16.000 \mathrm{NMP} / 100 \mathrm{~mL}$ (observado no poço P7). Novamente, os poços P5 e P7 apresentam as maiores médias geométricas de bactérias proteolíticas (312 e 171 NMP/100 $\mathrm{mL}$, respectivamente). Os clostrídios sulfito-redutores variam de menor que $2 \mathrm{NMP} / 100 \mathrm{~mL}$ a maior que 1.600 NMP/100mL (poços P1, P5, P7 e P10).

A Tabela 6.18 mostra os resultados das análises para vírus humanos. A Figura 6.18 exemplifica os resultados da reação em cadeia da polimerase (PCR), visando detecção de adenovírus em amostras de água subterrânea coletadas nos poços P8 e P10 em 26/10/1999. A presença de adenovírus nas águas dos poços P8 e P10 foi detectada, uma vez que pode ser visualizado o fragmento de 300 pares de base (pb) na figura. Fragmentos inexpressivos, apresentando tamanhos aproximados de $200 \mathrm{pb}$, também podem ser observados. Os enterovírus foram detectados nas amostras coletadas dos poços P8 e P10 em 21/03/2000. 
Tabela 6.17 Resultados das análises bacteriológicas

\begin{tabular}{|c|c|c|c|c|c|c|c|c|c|c|c|c|c|c|c|c|}
\hline \multirow{2}{*}{\multicolumn{2}{|c|}{ Poço 1}} & \multicolumn{3}{|c|}{$\begin{array}{c}\text { Bactérias } \\
\text { heterotróficas } \\
\text { (UFC/mL) }\end{array}$} & \multicolumn{3}{|c|}{$\begin{array}{l}\text { Coliformes totais } \\
\text { (NMP/100mL) }\end{array}$} & \multicolumn{3}{|c|}{$\begin{array}{l}\text { Coliformes fecais } \\
(\mathrm{NMP} / 100 \mathrm{~mL})\end{array}$} & \multicolumn{3}{|c|}{$\begin{array}{l}\text { Bactérias proteolíticas } \\
(\mathrm{NMP} / 100 \mathrm{~mL})\end{array}$} & \multicolumn{3}{|c|}{$\begin{array}{l}\text { Clostrídios sulfito- } \\
\text { redutores } \\
(\mathrm{NMP} / 100 \mathrm{~mL})\end{array}$} \\
\hline & & $\bar{X}_{G}$ & $x_{\min }$ & $x_{\max }$ & $\bar{X}_{G}$ & $x_{\text {min }}$ & $x_{\max }$ & $\bar{X}_{G}$ & $x_{\min }$ & $x_{\max }$ & $\bar{X}_{G}$ & $x_{\min }$ & $x_{\max }$ & $\bar{X}_{G}$ & $x_{\text {min }}$ & $x_{\max }$ \\
\hline P1 & 8 & $36 \mathrm{E} 3$ & 120 & $110 \mathrm{E} 4$ & 3 & $<2$ & 10 & 2 & $<2$ & 10 & 8 & $<2$ & 300 & 15 & $<2$ & $/ 1.600$ \\
\hline $\mathrm{P} 2$ & 2 & 47E3 & $70 \mathrm{E} 2$ & $32 \mathrm{E} 4$ & 3 & 2 & 4 & 1 & $<2$ & 2 & 24 & 14 & 40 & 3 & $<2$ & 12 \\
\hline P3 & 1 & $70 \mathrm{E} 2$ & & & 2 & & & 2 & & & 80 & & & 55 & & \\
\hline $\mathrm{P} 4$ & 3 & $140 \mathrm{E} 2$ & 90E2 & 30E3 & 5 & $<2$ & 13 & $<2$ & $<2$ & $<2$ & 56 & 20 & 300 & 18 & 4 & 50 \\
\hline P5 & 5 & $130 \mathrm{E} 3$ & 90E2 & 77E4 & 76 & 23 & 170 & 15 & 2 & 30 & 312 & 22 & 16.000 & 407 & 130 & $/ 1.600$ \\
\hline P6 & 5 & $250 \mathrm{E} 2$ & 30E2 & 130E3 & 8 & $<2$ & 350 & $<2$ & $<2$ & $<2$ & 18 & $<2$ & 360 & 31 & 4 & 900 \\
\hline P7 & 5 & 280E3 & $54 \mathrm{E} 3$ & 40E5 & 10 & $<2$ & $/ 1.600$ & 8 & $<2$ & $/ 1.600$ & 171 & 10 & $/ 16.000$ & 39 & $<2$ & $/ 1.600$ \\
\hline P8 & 5 & $46 \mathrm{E} 3$ & $50 \mathrm{E} 2$ & 290E3 & 5 & $<2$ & 30 & $<2$ & $<2$ & $<2$ & 9 & $<2$ & 280 & 29 & 4 & 1.400 \\
\hline P9 & 5 & $46 \mathrm{E} 3$ & $180 \mathrm{E} 2$ & $170 \mathrm{E} 3$ & 69 & $<2$ & $/ 1.600$ & 7 & $<2$ & 300 & 25 & $<2$ & 1.600 & 106 & 13 & 1.300 \\
\hline P10 & 5 & $73 \mathrm{E} 3$ & $50 \mathrm{E} 2$ & $440 \mathrm{E} 3$ & 6 & $<2$ & 30 & $<2$ & $<2$ & $<2$ & 31 & $<2$ & 1.600 & 43 & 1 & $/ 1.600$ \\
\hline P11 & 1 & 61E3 & & & 4 & & & $<2$ & & & $<20$ & & & 23 & & \\
\hline P13 & 2 & $52 \mathrm{E} 3$ & $32 \mathrm{E} 3$ & $86 \mathrm{E} 3$ & 2 & $<2$ & 4 & 1 & $<2$ & 2 & 71 & 10 & 500 & 173 & 23 & 1.300 \\
\hline P15 & 2 & $105 \mathrm{E} 3$ & 85E3 & $129 \mathrm{E} 3$ & $<2$ & $<2$ & $<2$ & $<2$ & $<2$ & $<2$ & 100 & 20 & 500 & 1.049 & 500 & 2.200 \\
\hline P19 & 4 & $35 \mathrm{E} 3$ & 75E2 & $152 \mathrm{E} 3$ & 10 & 2 & 23 & $<2$ & $<2$ & $<2$ & 18 & 2 & 170 & 34 & 8 & 170 \\
\hline $\mathrm{P} 20$ & 3 & $58 \mathrm{E} 3$ & 95E2 & $152 \mathrm{E} 3$ & 7 & 2 & 23 & $<2$ & $<2$ & $<2$ & 25 & 8 & 170 & 25 & 8 & 170 \\
\hline$n$ & & 56 & & & 56 & & & 56 & & & 56 & & & 56 & & \\
\hline $\bar{X}_{G}$ & & $53 \mathrm{E} 3$ & & & 8 & & & 2 & & & 31 & & & 45 & & \\
\hline$x_{\min }$ & & 120 & & & $<2$ & & & $<2$ & & & $<2$ & & & $<2$ & & \\
\hline$x_{\max }$ & & $40 \mathrm{E} 5$ & & & $/ 1.600$ & & & $/ 1.600$ & & & $/ 16.000$ & & & $/ 1.600$ & & \\
\hline
\end{tabular}

UFC: Unidade formadora de colônia; NMP: Número mais provável.

$n$ : número de observações; $\bar{X}_{G}$ : média geométrica; $x_{m i n}$ : valor mínimo observado; $x_{\max }$ : valor máximo observado 
Tabela 6.18 Resultados das análises para pesquisa de vírus humano

\begin{tabular}{l|cc|cc|cc}
\hline Poço & \multicolumn{6}{|c}{ Indicador } \\
\cline { 2 - 7 } & \multicolumn{2}{|c|}{$26 / 10 / 1999$} & \multicolumn{2}{c}{$07 / 02 / 2000$} & \multicolumn{2}{c}{$21 / 03 / 2000$} \\
& Adenovírus & Enterovírus & Adenovírus & Enterovírus & Adenovírus & Enterovírus \\
\hline P5 & - & - & - & - & - & - \\
P8 & + & - & - & - & - & + \\
P10 & + & - & - & - & - & + \\
\hline
\end{tabular}

-: abaixo do limite de detecção; +: detectado.

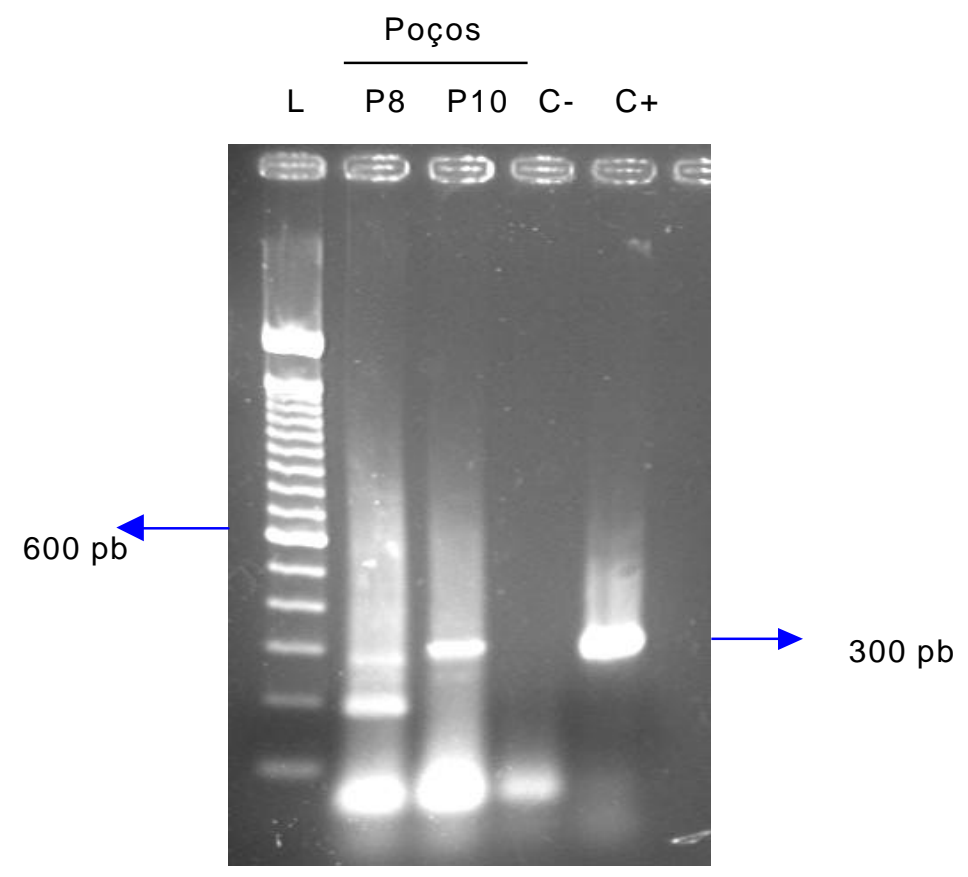

L: Marcador de peso molecular, DNA ladder de $100 \mathrm{pb}$ (pares de bases); P8: PCR da amostra do poço P8 em 26/10/1999; P10: PCR da amostra do poço P10 em 26/10 de 1999; C-: Controle negativo-água DEPC 0,1\%; C+: Controle positivo-Adenovírus 5.

Figura 6.18 Resultados da reação em cadeia da polimerase (PCR) para pesquisa de adenovírus 


\section{DISCUSSÃO}

\subsection{Etapa de laboratório}

\subsubsection{Inativação dos vírus}

Nos experimentos in vitro, o traçador biológico apresentou uma constante de inativação $\lambda=0,012 \mathrm{~h}^{-1}$ em meio aquoso de $\mathrm{pH}=5,0$ e temperatura de $25^{\circ} \mathrm{C}$, enquanto para $\mathrm{pH}=6,5 \mathrm{e}$ para a mesma temperatura, $\lambda=0,004 \mathrm{~h}^{-1}$. Ou seja, em meio mais ácido, a sobrevivência do T4 foi menor. Como a maioria dos outros microrganismos, o T4 é mais estável com pH próximo ao neutro, podendo sofrer alterações na membrana protéica, e nas capacidades de adsorção no hospedeiro e de infecção com mudanças no pH (KUTTER et al., 1994). Estes resultados são consistentes com os que foram observados por diversos autores (GERBA \& BITTON, 1984; YATES \& YATES, 1988; ZELIKSON, 1994). Os valores calculados de $\lambda$ foram utilizados no modelo numérico de simulação do transporte de vírus nas colunas de solo, ou seja, supomos que a inativação do T4 foi a mesma nos experimentos in vitro e nos experimentos de coluna.

A constante de inativação $\lambda$ foi determinada para o microrganismo considerado (colifago T4) e para as condições específicas do meio, que foram os efluentes da coluna de solo arenoso $(\mathrm{pH}=5,0)$ e da coluna de solo do cemitério de Vila Nova Cachoeirinha $(\mathrm{pH}=6,5)$. Diferentes valores de $\lambda$ poderiam ter sido determinados em outras condições ambientais, já que a sobrevivência dos vírus é função de vários fatores como temperatura, umidade, $\mathrm{pH}$ e outros (GERBA \& BITTON, op. cit.). PEKDEGER \& MATTHESS (1983) afirmam que a constante de inativação pode variar muito. No caso específico de vírus, foram observados valores entre $0,02 \mathrm{e}$ 0,44 dia $^{-1}$. PARK et al. (1994) resumiram as constantes de inativação de vários vírus em diversos estudos, mostrando valores entre 0,0103 e 3,2603 dia ${ }^{-1}$. DEBORDE et al. (1998) detectaram a presença do bacteriófago MS2 em poços de observação nove meses depois de terem sido injetados. SCHIJVEN et al. (1999) calcularam constantes de inativação para os bacteriófagos MS2 e PRD1, em laboratório e no campo, observando valores entre 0,0019 e 0,12 $\mathrm{dia}^{-1}$, com a temperatura variando entre 2 e $5^{\circ} \mathrm{C}$. 
A OMS (1979) assegura que os vírus podem persistir durante meses em águas naturais. CORAPCIOGLU \& HARIDAS (1984) afirmam que os vírus podem sobreviver de um a seis meses no meio ambiente. Segundo ROMERO (1970), em condições favoráveis, bactérias e vírus podem sobreviver por até cinco anos. Veremos mais adiante que há indícios que os enterovírus e adenovírus permanecem pelo menos um ano no cemitério de Vila Nova Cachoeirinha. Estudos adicionais devem ser realizados para verificar se os vírus continuam infecciosos.

\subsubsection{Adsorção dos vírus}

A relação entre a concentração em equilíbrio $C$ e a quantidade de vírus adsorvidos $C^{*}$ mostrou que os vírus são mais adsorvidos no solo do cemitério (solo 2) do que no solo arenoso (solo 1).

Considerando uma relação aproximadamente linear entre $C$ e $C^{*}$, os coeficientes de distribuição $K_{d}$ foram calculados em 51 e $295 \mathrm{~mL} / \mathrm{g}$ para os solos 1 e 2, respectivamente. A isoterma de adsorção linear é adequada se desconsiderarmos alguns valores mais altos de $C$, pois aumentando a concentração dos vírus em solução, chega-se a um ponto em que o solo já não consegue adsorver estes de maneira tão eficiente, como é observado na relação entre $C$ e $C^{*}$ para o solo arenoso (solo 1).

Os valores de $K_{d}$ calculados in vitro não foram capazes de expressar a adsorção do T4 nos solos 1 e 2 nos experimentos de coluna. Os coeficientes de distribuição $K_{d}$ estimados pelo modelo numérico são menores $(0,4$ e $1 \mathrm{~mL} / \mathrm{g}$ nas colunas de solo 1 e 2 , respectivamente). $\mathrm{Ou}$ seja, a adsorção sofrida pelo T4 nas colunas de solo foi muito menor do que aquela estimada pelo experimento in vitro. Esse resultado mostra que os experimentos realizados in vitro podem não ser adequados para representar a adsorção do T4 nos solos. Conclusões semelhantes foram registradas por POWELSON \& GERBA (1994), que também obtiveram adsorção muito maior nos experimentos in vitro quando comparados com os experimentos em colunas de solo. HENDRY et al. (1997) observaram que a adsorção de Klebsiella oxytoca em colunas de areia diminui com o aumento da escala de trabalho.

Diversos fatores físicos, químicos e biológicos atuam no processo de adsorção de vírus nos solos. Por isso, vários valores de $K_{d}$ foram observados em diferentes circunstâncias. PARK et al. (1994) resumem valores representativos de $K_{d}$ entre 0 e $2 \mathrm{~mL} / \mathrm{g}$ em materiais arenosos, entre 0 e $500 \mathrm{~mL} / \mathrm{g}$ em materiais siltosos e entre 2 e $2 \times 10^{4} \mathrm{~mL} / \mathrm{g}$ em materiais argilosos. Os 
valores aqui determinados de $K_{d}$ para os experimentos in vitro e em colunas devem ser utilizados levando-se em consideração as condições específicas do microrganismo e do meio.

\subsubsection{Transporte dos vírus}

A condutividade hidráulica $K$ da coluna de solo do cemitério $\left(1 \times 10^{-5} \mathrm{~m} / \mathrm{s}\right)$ é próxima do valor médio de $K$ determinado nos testes tipo slug $\left(1,32 \times 10^{-5} \mathrm{~m} / \mathrm{s}\right)$. Porém, a primeira deve ser considerada com algumas restrições, uma vez que a coluna de solo foi montada com amostras de solo deformadas e também porque foram determinados valores de $K$ desde $2,90 \times 10^{-8}$ até $8,41 \times$ $10^{-5} \mathrm{~m} / \mathrm{s}$ na área de estudo, mostrando que o meio é heterogêneo.

Os valores de dispersividade estimados para a coluna de solo arenoso ( $\alpha=0,03$ e 0,08 m) e do solo do cemitério $(\alpha=0,2 \mathrm{~m}$ ) são consistentes com resultados obtidos em outros experimentos de coluna (BALES et al., 1989; BALES et al., 1991; HENDRY et al., 1997; FETTER, 1999; SCHWARTZ et al., 1999). DOMENICO \& SCHWARTZ (1998) apontam valores típicos de dispersividade longitudinal de $10^{-2}$ a $1 \mathrm{~cm}$ em experimentos de coluna e de 0,1 a $2 \mathrm{~m}$ em experimentos de campo. A dispersividade $\alpha$ estimada no teste de traçador realizado em campo foi de $0,2 \mathrm{~m}$, igual àquela determinada na coluna de solo do cemitério. Nesse caso, é coerente obter valores semelhantes entre os experimentos de coluna e de campo, já que a escala de trabalho foi próxima ( $\mathrm{L}=0,34 \mathrm{~m}$ na coluna e $0,50 \mathrm{~m}$ no campo). A dispersividade $\alpha$ em campo foi estimada a partir de uma área muito pequena do cemitério, outros valores podem ser obtidos em outras condições do meio e de escala de trabalho.

No efluente da coluna de solo arenoso, a concentração máxima observada de cloreto é de aproximadamente $25 \%$ da concentração inicial $C_{0}$. Os vírus alcançam apenas $0,6 \%$ de $C_{0}$, sofrendo uma atenuação quase quarenta e duas vezes maior que o cloreto. No efluente da coluna de solo do cemitério, o pico de concentração de cloreto é cerca de $3,8 \%$ de $C_{0}$, em uma distância de 0,34 m, enquanto os vírus chegam a apenas $6 \times 10^{-5} \%$. Neste caso, a atenuação é sessenta e três vezes maior. Em resumo, a quantidade retida de vírus é maior do que a de cloreto e o solo do cemitério consegue reter mais vírus do que o solo arenoso.

É provável que a atenuação sofrida por vírus no cemitério de Vila Nova Cachoeirinha seja menor do que aquela observada na coluna de solo do cemitério ( $7 \log _{10}$ em $\left.0,34 \mathrm{~m}\right)$, uma vez que enterovírus e adenovírus foram detectados nos poços P8 e P10. Se a atenuação fosse a 
mesma, dificilmente os vírus seriam transportados mais que algumas dezenas de centímetros e não teriam sido observados nos poços. BALES et al. (1997) afirmaram que a atenuação estimada através dos resultados de seus experimentos de campo era dez vezes menor que aquela determinada em laboratório com traçadores biológicos. Discrepâncias entre parâmetros estimados em campo e em laboratório foram observadas por YEH (1992) apud BALES et al. (1997), MCCARTHY et al. (1996) apud BALES et al. (op. cit.) e SCHIJVEN et al. (1999).

A menos de um metro do poço P8 (Figura 7.1) - e estendendo-se a montante por cerca de 15 m - há sepultamentos recentes (abril de 1999 a julho de 2000) de crianças, principalmente neonatos. Mais acima, a $30 \mathrm{~m}$ do poço P8, são encontrados sepultamentos de adultos, de agosto de 1998. Os vírus encontrados no poço P8 não devem ter sua origem nas crianças, porque não foram encontrados outros indícios de contaminação recente, como bactérias proteolíticas. Poderíamos supor que a carga contaminante oriunda das covas de crianças não é expressiva, mas na verdade, não há informação disponível sobre a quantidade de vírus que um corpo em decomposição pode liberar. Sabe-se que enterovírus em fezes humanas podem chegar a $10^{5}-10^{8}$ $\mathrm{UFP} / \mathrm{g}$; que indivíduos infectados com rotavírus podem excretar até $10^{9}$ partículas por grama de fezes; que foram encontradas concentrações de enterovírus em esgotos de até $10^{5}$ partículas/L (OMS, 1979). Contudo, é difícil estimar a quantidade que efetivamente pode chegar ao aqüífero originada do corpo em decomposição. Estudos devem ser realizados nesta área.

A profundidade mínima do nível d'água no poço P8 é de 4,75 m. Como a profundidade de sepultamento é de $1,55 \mathrm{~m}$, os vírus foram transportados, no mínimo, 3,2 $\mathrm{m}$ na zona não saturada, até alcançar o aqüífero. Esse fato mostra que a distância mínima entre o fundo do sepultamento e o nível freático, estabelecida em 1,5 m pela Norma Técnica L1.040 (Anexo 1) da CETESB (1999), não é suficiente para reter os vírus.

Cerca de $50 \mathrm{~cm}$ separa o poço P10 (Figura 7.1) de sepultamentos de agosto e setembro de 1997. Dez metros a montante do poço, são encontradas inumações no solo de julho e agosto de 1998 que se estendem por aproximadamente $40 \mathrm{~m}$. Outras mais recentes (primeiro semestre de 1999) só foram encontradas a cerca de $120 \mathrm{~m}$ de P10. Considerando a velocidade linear média anteriormente determinada no cemitério de $8 \mathrm{~cm} /$ dia, vírus oriundos das sepulturas de 1999 não alcançariam o poço em menos de 1.500 dias. Portanto, é provável que aqueles vírus provenientes das sepulturas de 1998 alcançaram o poço P10, semelhante aos resultados encontrados no P8. 


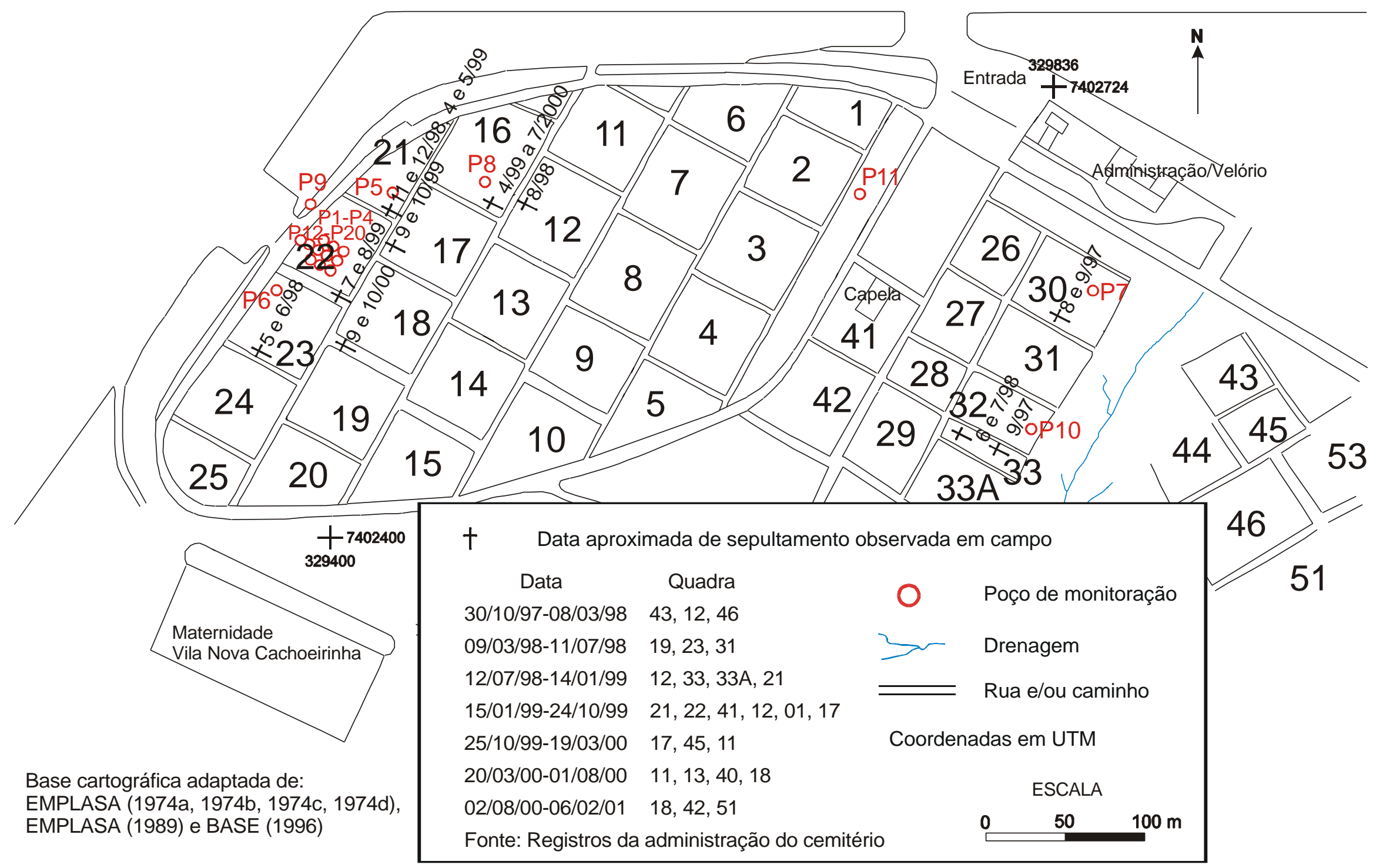

Figura 7.1 Mapa de localização e data aproximada dos sepultamentos 
O método empregado (PCR) na análise para detecção de adenovírus e enterovírus não pôde afirmar a quantidade existente nas amostras de água dos poços ou se estavam infecciosos. Todavia, os vírus foram transportados, no mínimo, algumas dezenas de metros, mantendo o seu genoma intacto pelo menos um ano. Os adenovírus são responsáveis por infecções oculares, respiratórias e gastrintestinais, enquanto alguns membros do gênero Enterovírus podem provocar meningite, poliomielite e cardiopatias. Além disso, podem estar presentes vírus causadores da hepatite do tipo A.

O modelo numérico de transporte de massa conseguiu simular satisfatoriamente o transporte dos traçadores químico e biológico e deve ser usado para fazer previsões sobre tempo de trânsito de microrganismos em meio poroso. Contudo, os parâmetros estimados podem ser outros para outras circunstâncias, uma vez que o transporte e retenção dos vírus são influenciados por diversos fatores citados anteriormente, como $\mathrm{pH}$ e temperatura. Vimos também que os parâmetros variam com a escala de trabalho: a dispersividade $\alpha$, por exemplo, aumenta com a escala; os coeficientes de distribuição $K_{d}$ de experimentos in vitro superestimam a adsorção observada em experimentos de coluna, os quais também superestimam a adsorção observada em campo. Ou seja, em campo, os vírus podem ser transportados para distâncias maiores que aquelas estimadas através de experimentos in vitro e em colunas.

Obter valores dos parâmetros nas condições reais de campo, só seria possível com a injeção e a monitoração do traçador biológico no cemitério, que não foram realizadas devido a diversas dificuldades. A própria natureza heterogênea do meio dificulta os estudos, assim como problemas desconhecidos que podem vir a surgir com a injeção de um microrganismo alóctone. Além disso, o comportamento de um colifago pode não ser igual ao de um enterovírus ou de um adenovírus. Se optarmos pela manipulação de patógenos humanos, teremos outras dificuldades como a possível periculosidade.

Além das dificuldades acima citadas em estimar os parâmetros, o modelo numérico utilizado fez algumas simplificações do fluxo das águas subterrâneas e do transporte dos vírus. O modelo foi solucionado em apenas uma dimensão; as propriedades hidráulicas do meio foram consideradas homogêneas; as propriedades do fluido não dependeram da concentração do contaminante; a adsorção dos vírus foi descrita pela isoterma de equilíbrio linear e a inativação por um decaimento de primeira ordem. 


\subsection{Etapa de campo}

\subsubsection{Estudos de investigação geofísica}

Os modelos geoelétricos mostraram que o embasamento está a uma profundidade de 9,0 $\mathrm{m}$ na cota mais baixa e $20,5 \mathrm{~m}$ no topo. Os matacões vistos próximos da área de estudo e as descrições lito-estratigráficas de poços anteriormente citados confirmam que o topo do embasamento encontra-se próximo à superfície do terreno. Não sabemos os locais precisos das sondagens elétricas realizadas por MENDES et al. (1989) - que apontaram profundidades do embasamento entre oito e trinta e seis metros no cemitério -, mas é provável que também sejam correspondentes a menor cota e ao topo do cemitério, respectivamente. Não foi possível confirmar a profundidade do embasamento, porque nenhum dos furos de sondagem chegou a ser perfurado até atingir a rocha sã.

As sondagens elétricas não foram capazes de estimar com precisão a profundidade do nível freático no local. A sondagem SE-8, por exemplo, infere uma camada condutiva a apenas 1 $\mathrm{m}$ de profundidade, mas os poços de monitoração mostram que o nível freático encontra-se entre quatro e cinco metros no local. No topo do cemitério, a sondagem elétrica infere uma profundidade de 12,0 $\mathrm{m}$ até a camada saturada, mas o poço P11 mostra que o nível freático está a, no mínimo, 16,53 $\mathrm{m}$ de profundidade. As camadas condutivas, observadas em algumas das sondagens (SEV-5, SEV-6, SEV-8), devem ser associadas a material mais argiloso, que forma aqüíferos suspensos confirmados por ocasião das sondagens geológicas e anteriormente observados por MENDES et al. (1989). As análises granulométricas das amostras de solo mostraram o domínio da fração argila nos primeiros $6 \mathrm{~m}$ de profundidade. Aqueles aqüíferos suspensos e/ou temporários são responsáveis pelo extravasamento do necrochorume nas ruas e vielas do cemitério que costuma ocorrer durante a época de chuvas.

Os sais minerais existentes no necrochorume atingem os aqüíferos suspensos e freático e acabam por aumentar a condutividade elétrica da água. Os locais de maior condutividade elétrica observados nos estudos eletromagnéticos foram escolhidos para a realização dos furos de sondagem, coleta de amostras e instalação dos poços de monitoração. Eles estão localizados nas cotas mais baixas, sendo relacionados à proximidade do nível freático da superfície e à presença de contaminação. 


\subsubsection{Indicadores químicos}

Os poços P6, P8 e P11 foram utilizados como valores de fundo ou de background, devido às suas localizações e à maior profundidade do nível freático. Porém, foram encontradas concentrações mais elevadas de $\mathrm{NO}_{3}{ }^{-}$(11,56 e 21,62 mg/L) nos poços P6 e P8. Além disso, adenovírus e enterovírus foram detectados no poço P8. O P11 teve um uso restrito, uma vez que só foi possível monitorá-lo por um breve período, pois o nível d'água ficou abaixo do seu filtro, durante os meses de menor precipitação.

Os resultados dos indicadores químicos mostraram que as águas subterrâneas mais próximas da superfície possuem maior condutividade elétrica (chega a atingir $600 \mu \mathrm{S} / \mathrm{cm}$ ) que as águas mais profundas (não passa de $200 \mu \mathrm{S} / \mathrm{cm}$ ), sugerINDO um enriquecimento em íons das águas mais vulneráveis. DENT apud WHO (1998) também observou aumento na condutividade elétrica nas águas subterrâneas próximas de sepulturas recentes no cemitério Botany, na Austrália. MIGLIORINI (1994) notou um aumento na condutividade elétrica e na concentração de íons maiores no cemitério de Vila Formosa, em São Paulo.

Os resultados das análises de íons e metais nas águas subterrâneas do cemitério de Vila Nova Cachoeirinha não foram satisfatórios, porque apenas os poços P5, P6, P8 e P10 tiveram um afastamento entre cátions e ânions abaixo de $10 \%$ no balanço iônico. Essas águas foram classificadas como bicarbonatadas cálcicas e sódicas, como é comum em se tratando de águas do município de São Paulo (PARISOT, 1983; SZIKSZAY et al., 1990; MENEGASSE, 1991; MENEGASSE VELASQUEZ, 1996) e do Estado de São Paulo (CAMPUS, 1993 apud ROSA, 1999). MIGLIORINI (1994) classificou as águas do cemitério de Vila Formosa, em São Paulo, como bicarbonatadas cálcicas e sódicas.

As águas dos poços P5 e P10 possuem mais ferro, alumínio, chumbo e zinco do que os P6 e P8. Considerando a possibilidade de pessoas captarem a água subterrânea na proximidade do cemitério, através de poços rasos, e tomando os padrões de potabilidade estabelecidos pela Portaria $\mathrm{n}^{\mathrm{o}} 36$ do MINISTÉRIO DA SAÚDE (1990), as quantidades de $\mathrm{Mn}^{2+}, \mathrm{Pb}^{2+}$ e $\mathrm{Al}^{3+}$ nos poços P5, P6, P8 e P10 estão acima dos valores máximos admissíveis que são de 0,1, 0,05 e 0,2 $\mathrm{mg} / \mathrm{L}$, respectivamente. É importante mencionar que aquela portaria foi substituída pela Portaria nº 1.469 (MINISTÉRIO DA SAÚDE, 2001), publicada no Diário Oficial em 19 de janeiro de 
2001, concedendo 24 meses para que instituições e órgãos se adaptem ao cumprimento dos novos padrões.

Os poços P5, P6, P8 e P10 não apresentaram concentrações elevadas de nitrato ou nitrito, mas isso não implica na ausência de produtos nitrogenados no cemitério, porque não foram analisados outros compostos menos oxidados como o nitrogênio orgânico, amônia $\left(\mathrm{NH}_{3}\right)$ e amônio $\left(\mathrm{NH}_{4}{ }^{+}\right)$. PEQUENO MARINHO (1998) encontrou a ocorrência de produtos nitrogenados nas águas subterrâneas do cemitério São João Batista, em Fortaleza. MIGLIORINI (1994) também encontrou concentrações elevadas de $\mathrm{NH}_{4}{ }^{+}$e $\mathrm{NO}_{3}{ }^{-}$no cemitério de Vila Formosa em São Paulo que, segundo esse autor, provêm do processo de decomposição dos corpos que produz diaminas, como a cadaverina $\left(\mathrm{C}_{5} \mathrm{H}_{14} \mathrm{~N}_{2}\right)$ e a putrescina $\left(\mathrm{C}_{4} \mathrm{H}_{12} \mathrm{~N}_{2}\right)$, que podem ser degradadas, gerando $\mathrm{NH}_{4}{ }^{+}$.

É possível que MIGLIORINI (1994) tenha encontrado quantidades elevadas de $\mathrm{NH}_{4}{ }^{+}$no cemitério de Vila Formosa, devido à escassez de oxigênio imposta pelo alto consumo deste pelas bactérias e reações de oxidação. No cemitério de Vila Nova Cachoeirinha, as águas mais próximas da superfície apresentam menor quantidade de oxigênio dissolvido ( 1,6 mg/L) do que as águas mais profundas (P6, P8) que possuem, em média, 3,2 mg/L. Naquele ambiente redutor, nitrogênio orgânico e amônio são mais estáveis, como foi observado em efluente de fossa séptica no Parque Ecológico do Tietê em São Paulo (VARNIER \& HIRATA, 2000). Mais distante da fonte de contaminação, como nos poços P6 e P8, encontramos o nitrogênio na sua forma mais oxidada $\left(\mathrm{NO}_{3}{ }^{-}\right)$. Estas suposições precisariam ser confirmadas através da monitoração mais eficiente dos indicadores químicos, incluindo todos os compostos de nitrogênio e, claro, de melhores resultados analíticos das análises químicas.

As águas mais profundas apresentam um $\mathrm{pH}$ menor do que as águas mais próximas da superfície. Esse fato também foi observado por MIGLIORINI (1994) no cemitério de Vila Formosa.

\subsubsection{Indicadores microbiológicos}

A pesquisa de indicadores microbiológicos demonstrou a presença, principalmente, de bactérias heterotróficas, proteolíticas e clostrídios sulfito-redutores nas águas subterrâneas do cemitério. Considerando a possibilidade das pessoas captarem essa água para beber, coliformes totais e fecais não devem ser encontrados em águas potáveis, e o número de bactérias 
heterotróficas não deve ultrapassar 500 UFC/mL (MINISTÉRIO DA SAÚDE, 1990). A Portaria n⿳⺈ 36 não faz menção aos outros indicadores analisados neste estudo.

Os poços P5, P7 e P9 apresentaram os maiores números dos indicadores pesquisados. O poço P5 teve as maiores médias geométricas $\bar{X}_{G}$ de bactérias heterotróficas $\left(130 \times 10^{3}\right.$ UFC/mL), coliformes totais (76 NMP/100 mL), fecais (15 NMP/100 mL), bactérias proteolíticas (312 NMP/100 mL) e a segunda maior média geométrica de clostrídios sulfito-redutores (407 NMP/100 mL). Durante as coletas, a água do P5 tinha odor nauseabundo, podendo estar relacionado à presença do necrochorume. Neste poço, também foram observadas concentrações elevadas de bicarbonato, cloreto, sódio e cálcio, quando comparado com os poços P6 e P8 onde o nível freático está mais profundo. A menos de $2 \mathrm{~m}$ a montante do poço P5, existem sepultamentos de novembro de 1998 a maio de 1999 que se estendem por aproximadamente 20 m. Aquelas covas parecem ser a fonte principal de contaminação do poço.

No poço P7, foram detectadas concentrações mais elevadas de bactérias heterotróficas $\left(\bar{X}_{G}=280 \times 10^{3} \mathrm{UFC} / \mathrm{mL}\right)$, coliformes totais $\left(\bar{X}_{G}=10 \mathrm{NMP} / 100 \mathrm{~mL}\right)$, fecais $\left(\bar{X}_{G}=8\right.$ NMP/100 mL) e bactérias proteolíticas $\left(\bar{X}_{G}=312 \mathrm{NMP} / 100 \mathrm{~mL}\right)$, quando comparadas com valores de fundo ou background (P6 e P8). Os sepultamentos a montante do P7 são de agosto e setembro de 1997. Cerca de $10 \mathrm{~m}$ para cima, existe uma área de jazigos permanentes com sepulturas em datas diversas. Os poços P7 e P10, apesar de não estarem próximos de sepultamentos recentes, estão em uma área onde foi observada a presença de aqüíferos suspensos durante a execução das sondagens geológicas. É possível que a contaminação observada no P7, e em menor escala no P10, seja oriunda de corpos saponificados, que segundo PACHECO \& BATELLO (2000) podem ser fontes de contaminação.

O poço P9 é contíguo ao muro do cemitério e apresenta números elevados de coliformes totais $\left(\bar{X}_{G}=69 \mathrm{NMP} / 100 \mathrm{~mL}\right)$ e fecais $\left(\bar{X}_{G}=7 \mathrm{NMP} / 100 \mathrm{~mL}\right)$. Acreditamos que o P9 sofra uma influência maior da galeria de águas pluviais que se encontra a menos de $1 \mathrm{~m}$ deste. Os números elevados de bactérias encontrados neste poço não são resultantes dos sepultamentos no cemitério, mas de possíveis vazamentos da galeria que, provavelmente, recebe esgotos. Análises bacteriológicas de amostras de água do córrego canalizado que atravessa o cemitério apresentaram número elevado de coliformes totais $(>16.000 \mathrm{NMP} / 100 \mathrm{~mL})$ e fecais $(>16.000$ NMP/100 mL), demonstrando a contribuição direta de esgotos (MATOS et al., 1998). Análises bacteriológicas realizadas por TÔRRES (1992b) também mostraram concentrações elevadas de 
coliformes totais $\left(\bar{X}_{G} \cong 1.600 \mathrm{NMP} / 100 \mathrm{~mL}\right)$ e fecais $\left(\bar{X}_{G} \cong 80 \mathrm{NMP} / 100 \mathrm{~mL}\right)$ em poços próximos ao muro do cemitério, onde hoje está o P9.

Observar aumento nas concentrações de coliformes totais e fecais em áreas mais a jusante das sepulturas, como o que aconteceu no P9 no cemitério de Vila Nova Cachoeirinha, e foi observado no cemitério do Benguí, em Belém (CARVALHO JUNIOR \& COSTA E SILVA, 1997; BRAZ et al., 2000) deve ser visto com desconfiança. Pode ser outra a fonte de contaminação, que não os cemitérios.

Os números observados de bactérias heterotróficas $\left(\bar{X}_{G}=53 \times 10^{3} \mathrm{UFC} / \mathrm{mL}\right)$, coliformes totais $\left(\bar{X}_{G}=8 \mathrm{NMP} / 100 \mathrm{~mL}\right)$ e fecais $\left(\bar{X}_{G}=2 \mathrm{NMP} / 100 \mathrm{~mL}\right)$ no cemitério de Vila Nova Cachoeirinha foram semelhantes aqueles observados por PACHECO et al. (1991). O número de clostrídios sulfito-redutores $\left(\bar{X}_{G}=45 \mathrm{NMP} / 100 \mathrm{~mL}\right.$ ) foi cerca de seis vezes maior que o encontrado no estudo daqueles autores, enquanto o de bactérias proteolíticas $\left(\bar{X}_{G}=31\right.$ $\mathrm{NMP} / 100 \mathrm{~mL}$ ) foi trinta e três vezes menor.

As bactérias heterotróficas - aquelas que usam compostos orgânicos como fonte de carbono - foram encontradas em números elevados em todos os poços, principalmente naqueles próximos da fonte de contaminação, funcionando bem como indicadores. Os coliformes totais e fecais foram detectados em concentrações maiores apenas nos poços próximos das fontes de contaminação, mostrando que são transportados para distâncias de alguns metros. Apesar de serem bons indicadores de contaminação de origem humana ou animal, as bactérias do grupo coliforme não são tão resistentes no meio ambiente; além disso, elas podem ser inibidas pela presença de outras bactérias (CETESB, 1996). A utilização destas bactérias para o estudo do transporte de contaminantes em cemitérios, e em geral nas águas subterrâneas, deve ser considerada com cuidado, uma vez que outros contaminantes mais persistentes, como os vírus, podem ser transportados no meio poroso para distâncias maiores (KESWICK et al., 1982).

As bactérias proteolíticas são responsáveis pela hidrólise das proteínas. Análise de uma amostra do percolado de sepultamentos, coletada em março de 2000 por ocasião do extravasamento em uma rua do cemitério, apresentou números elevados de bactérias proteolíticas (9.000 NMP/100 mL). O emprego destas bactérias como indicador foi eficiente na detecção da contaminação oriunda de sepultamentos. Os clostrídios também funcionaram bem como indicadores da contaminação, mostrando a sua persistência no meio. 
Os resultados indicam que as bactérias foram transportadas alguns metros, e os vírus, algumas dezenas de metros. A maioria dos estudos realizados (ROMERO, 1970; KESWICK et al. 1982; MCDOWELL-BOYER et al., 1986; ALHAJJAR et al., 1988) mostram que os vírus alcançam distâncias maiores que as bactérias. Porém, não é consenso de todos os estudos, segundo WHO (1998), os vírus podem ser retidos no solo por adsorção, atingindo distâncias menores que as bactérias. 


\section{ASPECTOS LEGAIS}

\section{1 ÂAmbito federal}

Na esfera federal, não há legislação específica ou norma técnica regulamentando a implantação e operação de cemitérios em termos ambientais e sanitários. Existem iniciativas por parte de alguns estados brasileiros, como a Norma Técnica L1.040 (Anexo 1) do órgão responsável pelo controle ambiental do Estado de São Paulo (CETESB) e um Termo de Referência (PARÁ, 1996 apud BRAZ et al., 2000) elaborado pela Secretaria de Ciência, Tecnologia e Meio Ambiente do Estado do Pará.

Apesar de não tratarem especificamente de implantação de cemitérios visando a proteção ambiental, algumas leis estaduais e municipais fazem algumas exigências sobre o assunto, pois tratam de questões relativas à saúde pública, construção de cemitérios, e outros. Um exemplo é o Decreto "E” no. 3.707 (RIO DE JANEIRO, 1970) - regulamenta o Decreto-Lei No. 88 (RIO DE JANEIRO, 1969) -, dispondo sobre a criação de cemitérios no município do Rio de Janeiro e exigindo, entre outros, sondagens geológicas do terreno e que o nível freático esteja à profundidade mínima de $3 \mathrm{~m}$ em áreas de sepultamento.

\section{2 $\underline{\text { Âmbito estadual }}$}

A CETESB elaborou a Norma Técnica L1.040 em 1989. Revista em 1993 e 1999 (Anexo 1), estabelece os requisitos e as condições técnicas para a implantação de cemitérios destinados ao sepultamento no subsolo, no que tange à proteção do ambiente, em particular do solo e das águas subterrâneas. A norma exige que o empreendedor de cemitério apresente uma caracterização da área, com informações geográficas, geológicas e hidrogeológicas; distância mínima de 1,5 m entre o nível freático e o nível inferior das sepulturas, ou rebaixamento do nível freático, entre outros.

O Código Sanitário do Estado de São Paulo (SÃO PAULO, 1991) - regulamenta a promoção, preservação e recuperação da saúde - exige que os cemitérios sejam construídos em áreas elevadas, na contravertente das águas que possam alimentar poços e outras fontes de 
abastecimento (Anexo 1). O código ainda estabelece perímetros mínimos de proteção, ordena que a área do cemitério não esteja sujeita a inundações e afirma que o nível do lençol freático deve ficar a pelo menos 2,00 m de profundidade, entre outros. Porém, no que cabe a cemitérios, o texto é confuso e acaba por inviabilizar o seu pleno cumprimento. 


\section{CONCLUSÕES}

A pesquisa de indicadores microbiológicos demonstrou a presença, principalmente, de bactérias heterotróficas $\left(53 \times 10^{3} \mathrm{UFC} / \mathrm{mL}\right)$, bactérias proteolíticas $(31 \mathrm{NMP} / 100 \mathrm{~mL}) \mathrm{e}$ clostrídios sulfito-redutores (45 NMP/100 mL) nas águas subterrâneas do cemitério de Vila Nova Cachoeirinha. Também foram encontrados enterovírus e adenovírus.

As bactérias heterotróficas foram encontradas em números elevados em todos os poços, principalmente naqueles mais próximos da fonte de contaminação, funcionando bem como indicadores. Os coliformes totais e fecais foram detectados em concentrações maiores apenas nos poços próximos dos sepultamentos, mostrando que alcançam distâncias de poucos metros. As bactérias proteolíticas foram eficientes na detecção da contaminação oriunda de sepultamentos. Os clostrídios também funcionaram bem como indicadores da contaminação, mostrando a sua persistência no meio.

As principais fontes de contaminação das águas subterrâneas no cemitério são as sepulturas com menos de um ano localizadas nas cotas mais baixas, próximas ao nível freático. Nestes locais, é maior a ocorrência de bactérias em geral. Há um grande consumo do oxigênio existente nas águas. As sepulturas ainda provocam um acréscimo na quantidade de sais minerais, aumentando a condutividade elétrica destas águas. Parece haver um aumento na concentração dos íons maiores bicarbonato, cloreto, sódio e cálcio, e dos metais ferro, alumínio, chumbo e zinco nas águas próximas de sepulturas.

As bactérias são transportadas alguns metros, diminuindo em concentração com o aumento da distância à fonte de contaminação. Os vírus parecem ter uma mobilidade maior que as bactérias, alcançando, no mínimo, algumas dezenas de metros no aqüífero freático do cemitério de Vila Nova Cachoeirinha. Os vírus foram transportados, pelo menos, 3,2 m na zona não saturada até alcançar o aqüífero.

No cemitério, o embasamento está à cerca de 9,0 m de profundidade na cota mais baixa e 20,5 m no topo. O nível freático encontra-se entre 4,0 e mais de 16,0 m de profundidade. O solo do cemitério é formado pelo material de alteração das rochas graníticas, de caráter predominantemente argiloso ( 43\% de argila), $\mathrm{pH}=5,0$, matéria orgânica entre 0,7 e 4,2\% e capacidade de troca de cátions entre 10,2 e 109,0 mmolc/kg. A fração argila é constituída principalmente por caulinita e óxidos de ferro e alumínio. 
A condutividade hidráulica do aqüífero varia de $2,90 \times 10^{-8}$ a $8,41 \times 10^{-5} \mathrm{~m} / \mathrm{s}$. O gradiente hidráulico na porção oeste do cemitério é de aproximadamente $0,07 \mathrm{~m} / \mathrm{m}$; considerando o meio homogêneo e isotrópico e uma porosidade efetiva de $2 \%$, a velocidade linear média foi estimada $\mathrm{em} 8 \mathrm{~cm} /$ dia.

O bacteriófago T4 foi utilizado, satisfatoriamente, como traçador biológico, apresentando uma constante de inativação $\lambda=0,012 \mathrm{~h}^{-1}$ em meio aquoso de $\mathrm{pH}=5,0$ e temperatura de $25^{\circ} \mathrm{C}$, enquanto em $\mathrm{pH}=6,5$ e para a mesma temperatura, $\lambda=0,004 \mathrm{~h}^{-1}$.

A adsorção do T4 no solo do cemitério de Vila Nova Cachoeirinha foi representada pela isoterma de adsorção linear com um coeficiente de distribuição $K_{d}$ de $1 \mathrm{~mL} / \mathrm{g}$ no experimento de coluna. Os experimentos realizados in vitro $\left(K_{d}=295 \mathrm{~mL} / \mathrm{g}\right)$ não conseguiram representar satisfatoriamente a adsorção do T4 na coluna de solo do cemitério. A atenuação sofrida pelo T4, na coluna $\left(\sim 7 \log _{10}\right.$ em $\left.0,34 \mathrm{~m}\right)$ deve ser maior do que a sofrida por vírus no cemitério, uma vez que enterovírus e adenovírus foram detectados nos poços P8 e P10. Os valores de dispersividade $\alpha$ estimados pelo modelo numérico foram de $0,2 \mathrm{~m}$ na coluna de solo do cemitério e $0,2 \mathrm{~m}$ no teste de traçador realizado em campo. 


\section{RECOMENDAÇÕES}

Os cemitérios são fontes potenciais de contaminação das águas subterrâneas, pelo simples fato de serem laboratórios de decomposição de matéria orgânica, durante a qual está presente uma infinidade de microrganismos. Como forma de controlar os riscos que aquele tipo de construção apresenta, sugerimos as seguintes recomendações:

1. A elaboração de projetos para implantação de cemitérios deve cumprir exigências de prefeituras e órgãos ambientais visando a proteção e preservação do solo e das águas subterrâneas;

2. Deve ser elaborada uma legislação nacional regulamentando a implantação e operação de cemitérios, em termos ambientais e sanitários;

3. No que tange ao Estado de São Paulo, a legislação sobre cemitérios, contida no Código Sanitário, deve ser tratada como matéria especial;

4. Os cemitérios também devem constar da lista de fontes potenciais de contaminação das águas subterrâneas;

5. Mais estudos sobre a contaminação das águas subterrâneas por cemitérios, em especial, a carga potencial poluidora, a composição química e bacteriológica do necrochorume, e o impacto gerado por corpos saponificados;

6. Mais estudos devem ser feitos sobre o transporte de microrganismos, em particular, de vírus, porque desconhecemos o comportamento destes em ambiente cemiterial. 


\section{REFERÊNCIAS BIBLIOGRÁFICAS}

ALLARD, A.; GIRONES, R.; PER JUTO; WADELL, G. (1990) Polymerase chain reaction for detection of adenoviruses in stool samples. Journal of Clinical Microbiolog. v. 28, p. 26592667.

AMERICAN PUBLIC HEALTH ASSOCIATION - APHA (1995) Standard methods for the examination of water and wastewater. 19th ed. Washington, APHA, AWWA, WEF.

AMERICAN TYPE CULTURE COLLECTION - ATCC (2000) American Type Culture Collection. Disponível em <http://www.atcc.org>. Acesso em 25 set. 2000

ARIÈS, P. (1977) O homem perante a morte. Lisboa, Europa América. 2v. 714 p.

ASSOCIAÇÃO BRASILEIRA DE GEOLOGIA DE ENGENHARIA - ABGE (1990) Manual de sondagens. 3. ed. São Paulo, ABGE. 73 p. (Boletim n.3).

ASSOCIAÇÃO BRASILEIRA DE NORMAS TÉCNICAS - ABNT (1997) Construção de poços de monitoramento e amostragem - (NBR 13895). Rio de Janeiro, ABNT. 21 p.

BAARS, J.K. (1957) Travel of pollution, and purification em route, in sandy soils. Bulletin of the World Health Organization, v. 16, p. 727-747.

BALES, R.C.; GERBA, C.P.; GRONDIN, G.H.; JENSEN, S.L. (1989) Bacteriophage transport in sandy soil and fractured tuff. Applied and Environmental Microbiology, v. 55, n. 8, p. 2061-2067.

BALES, R.C.; HINKLE, S.R.; KROEGER, T.W.; STOCKING, K.; GERBA, C.P. (1991) Bacteriophage adsorption during transport through porous media: chemical perturbations and reversibility. Environmental Science and Technology, v. 25, n. 12, p. 2088-2095.

BALES, R.C.; LI, S.; MAGUIRE, K.M.; YAHYA, M.T.; GERBA, C.P. (1993) MS-2 and poliovirus transport in porous media: Hydrophobic effects and chemical pertubations. Water Resources Research, v. 29, n. 4, p. 957-963.

BALES, R.C.; LI, S.; YEH, T.-C.J.; LENCZEWSKI, M.E.; GERBA, C.P. (1997) Bacteriophage and microsphere transport in saturated porous media: Forced-gradient experiment at Borden, Ontario. Water Resources Research, v. 33, n. 4, p. 639-648.

BASE AEROFOTOGRAMETRIA E PROJETOS (1996) Projeto P.M.S.P.-RESOLO: foto aérea. São Paulo. Fx 21 ${ }^{\mathrm{A}}$, n. 04. (Escala 1:5.000).

BAYARD, J.P. (1993) Le sens caché des rites mortuaires. France, Dangle, 330 p. 
BERGAMO, H. (1954) Os cemitérios - Um problema de engenharia sanitária. In: CONGRESSO INTERAMERICANO DE ENGENHARIA SANITÁRIA, 4., São Paulo, 1954. Anais. São Paulo, AIES, p. 333-339.

BOUWER, H. (1984) Elements of soil science and groundwater hydrology. In: BITTON, G.; GERBA, C.P. (Eds.). Groundwater pollution microbiology. New York, John Wiley \& Sons. p. 9-38.

BOUWER, H.; LANCE, J.C.; RIGGS, M.S. (1974a) High rate land treatment II: Water quality and economic aspects of the Flushing Meadows project. Journal of the Water Pollution Control Federation, v. 46, n. 5, p. 844-859.

BOUWER, H.; RICE, R.C.; ESCARCEGA, E.D. (1974b) High rate land treatment I: infiltration and hydraulic aspects of the Flushing Meadows project. Journal of the Water Pollution Control Federation, v. 46, n. 5, p. 834-843.

BOUWER, H. (1978) Groundwater hydrology. New York, Mc Graw Hill. 480 p.

BRAZ, V.; BECKMANN; COSTA E SILVA, L. (2000) Integração de resultados bacteriológicos e geofísicos na investigação da contaminação de águas por cemitérios. In: CONGRESSO MUNDIAL INTEGRADO DE ÁGUAS SUBTERRÂNEAS, 1., Fortaleza, 2000. Anais. Fortaleza, ABAS. 1 CD-ROM.

CALDWELL, E.L. (1938) Studies of subsoil pollution in relation to possible contamination of the ground water from human excreta deposited in experimental latrines. Journal of Infectious Diseases, v. 62, n. 3, p.272-292.

CALDWELL, E.L.; PARR, L.W. (1937) Ground water pollution and the bored hole latrine. Journal of Infectious Diseases, v. 61, n. 2, p. 148-183.

CALDWELL, E.L.; PARR, L.W. (1938) Direct measurement of the rate of ground water flow in pollution studies. Journal of Infectious Diseases, v. 62, n. 3, p. 259-271.

CARLSON, K.; MILLER, E.S. (1994a) Working with T4. In: KARAM, J.D. (Ed.). Molecular biology of bacteriophage T4. Washington, American Society for Microbiology. p. 421-426.

CARLSON, K.; MILLER, E.S. (1994b) General procedures. In: KARAM, J.D. (ed). Molecular biology of bacteriophage T4. Washington, American Society for Microbiology. p. 427-437.

CARVALHO JUNIOR, M.A.F.; COSTA E SILVA, L.M. (1997) SP e eletrorresistividade aplicados ao estudo hidrogeológico de um cemitério. In: CONGRESSO INTERNACIONAL DA SOCIEDADE BRASILEIRA DE GEOFÍSICA, 5., São Paulo, 1997. Resumos Expandidos. São Paulo, Sociedade Brasileira de Geofísica, v. 1, p. 471-474.

CASTRO, M.G.S. (1993) A chuva ácida na cidade de São Paulo. São Paulo, 153 p. Dissertação (Mestrado) - Departamento de Geografia da Faculdade de Filosofia, Letras e Ciências Humanas, Universidade de São Paulo.

CHRYSIKOPOULOS, C.V.; SIM, Y.; (1996) One-dimensional virus transport in homogeneous porous media with time-dependent distribution coefficient. Journal of Hydrology, v. 185, p. 199-219. 
COMPANHIA DE TECNOLOGIA DE SANEAMENTO AMBIENTAL - CETESB (1988)

Guia de coleta e preservação de amostras de água. São Paulo, CETESB. 150 p.

COMPANHIA DE TECNOLOGIA DE SANEAMENTO AMBIENTAL - CETESB (1993a) Coliformes totais e fecais - Determinação pela técnica de tubos múltiplos. São Paulo, CETESB. 39 p. (Norma L5.202).

COMPANHIA DE TECNOLOGIA DE SANEAMENTO AMBIENTAL - CETESB (1993b) Clostridium perfringes - Determinação em amostras de água pela técnica de tubos múltiplos. São Paulo, CETESB. 28 p. (Norma L5.213).

COMPANHIA DE TECNOLOGIA DE SANEAMENTO AMBIENTAL - CETESB (1996) Bactérias heterotróficas. Contagem em placas. São Paulo, CETESB. 26 p. (Norma L5.201)

COMPANHIA DE TECNOLOGIA DE SANEAMENTO AMBIENTAL - CETESB (1999) Implantação de cemitérios. São Paulo, CETESB. 6 p. (Norma L1.040).

CORAPCIOGLU, M.Y.; HARIDAS, A. (1984) Transport and fate of microorganisms in porous media: A theoretical investigation. Journal of Hydrology, v. 72, p. 149-169.

CORAPCIOGLU, M.Y.; HARIDAS, A. (1985) Microbial transport in soils and groundwater: A numerical model. Advances in Water Resources, v. 8, p. 188-200.

DANTAS, A.S.L. (1990) Geologia da faixa São Roque e intrusivas associadas na região entre São Paulo e Mairiporã, norte de São Paulo, SP. São Paulo, 199 p. Dissertação (Mestrado) Instituto de Geociências, Universidade de São Paulo.

DEBORDE, D.C.; WOESSNER, W.W.; LAUERMAN, B.; BALL, P.N. (1998) Virus ocuurrence and transport in a school septic system and unconfined aquifer. Ground Water, v. 36 , n. 5, p. 825-834.

DEPARTAMENTO DE ÁGUAS E ENERGIA ELÉTRICA - DAEE (1975) Estudo de águas subterrâneas: região administrativa 1 - Grande São Paulo. São Paulo, DAEE. 3 v.

DEPARTAMENTO DE ÁGUAS E ENERGIA ELÉTRICA - DAEE (1998) Banco de dados pluviométricos do Estado de São Paulo: versão 1.0. São Paulo, Secretaria de Recursos Hídricos, Saneamento e Obras/DAEE/CTH-USP. 1 CD-ROM.

DOMENICO, P.A.; SCHWARTZ, F.W. (1998) Physical and chemical hydrogeology. 2nd ed. New York, John Wiley and Sons. 506 p.

DREWRY, W. A.; ELIASSEN, R. (1968) Virus movement in groundwater. Journal of the Water Pollution Control Federation, v. 40, p. 257-271.

EMPRESA BRASILEIRA DE PESQUISA AGROPECUÁRIA - EMBRAPA (1997) Manual de métodos de análise de solo. 2. ed. Rio de Janeiro, EMBRAPA. 212 p.

EMPRESA METROPOLITANA DE PLANEJAMENTO DA GRANDE SÃO PAULO EMPLASA (1974a) Sistema cartográfico metropolitano da grande São Paulo: levantamento aerofotogramétrico - Folha Vila Nova Cachoeirinha (SF 23 Y C III 4 SO F I 5). São Paulo, EMPLASA. (Escala 1:2.000). 
EMPRESA METROPOLITANA DE PLANEJAMENTO DA GRANDE SÃO PAULO EMPLASA (1974b) Sistema cartográfico metropolitano da grande São Paulo: levantamento aerofotogramétrico - Folha Vila Nova Cachoeirinha (SF 23 Y C III 4 SO F I 6). São Paulo, EMPLASA. (Escala 1:2.000).

EMPRESA METROPOLITANA DE PLANEJAMENTO DA GRANDE SÃO PAULO EMPLASA (1974c) Sistema cartográfico metropolitano da grande São Paulo: levantamento aerofotogramétrico - Folha Casa Verde/Vila Nova Cachoeirinha/Limão (SF 23 Y C III 4 SO F III 2). São Paulo, EMPLASA. (Escala 1:2.000).

EMPRESA METROPOLITANA DE PLANEJAMENTO DA GRANDE SÃO PAULO EMPLASA (1974d) Sistema cartográfico metropolitano da grande São Paulo: levantamento aerofotogramétrico - Folha Casa Verde (SF 23 Y C III 4 SO III 3)São Paulo, EMPLASA. (Escala 1:2.000).

EMPRESA METROPOLITANA DE PLANEJAMENTO DA GRANDE SÃO PAULO EMPLASA (1989) Sistema cartográfico metropolitano da grande São Paulo: levantamento aerofotogramétrico. Folha Santana (SF-23-Y-C-III-4-SO-F). São Paulo, EMPLASA. (Escala 1:10.000).

FETTER, C.W. (1994) Applied hydrogeology. 3rd ed. Upper Saddle River, Prentice Hall. 691 p.

FETTER, C.W. (1999) Contaminant hydrogeology. 2nd ed. Upper Saddle River, Prentice Hall. $500 \mathrm{p}$.

FLETCHER, M.W.; MYERS, R.L. (1974) Groundwater tracing in karst terrain using bacteriophage T-4. In: ANNUAL MEETING OF THE AMERICAN SOCIETY FOR MICROBIOLOGY. 1974. Abstracts. American Society for Microbiology. p. 52.

GERBA, C.P.; BITTON, G. (1984) Microbial pollutants: their survival and transport pattern to groundwater. In: BITTON, G.; GERBA, C.P. (Eds.). Groundwater pollution microbiology. New York, John Wiley \& Sons. p. 65-88.

GERBA, C.P.; WALLIS, C.; MELNICK, J.L. (1975) Fate of wastewater bacteria and viruses in soil. Journal of the Irrigation and Drainage Division, v. 101, n. IR3, p. 157-174.

GOLDSHMID, J. (1974) Water-quality aspects of ground-water recharge in Israel. Journal of the American Water Works Association, v. 66, n. 3, p. 163-166.

GRANT, S.B.; LIST, E.J.; LIDSTROM, M.E. (1993) Kinetic analysis of virus adsorption and inactivation in batch experiments. Water Resources Research, v. 29, n. 7, p. 2067-2085.

HENDRY, M.J.; LAWRENCE, J.R.; MALOSZEWSKI, P. (1997) The role of sorption in the transport of Klebsiella oxytoca through saturated silica sand. Ground Water, v. 35, n. 4, p. 574-584.

HYPOLITO, R. (1998) Alcalinidade. São Paulo, Instituto de Geociências/USP. 52 p. (Apostila da disciplina Geoquímica da Interação solo/rocha/água).

INSTITUTO BRASILEIRO DE GEOGRAFIA E ESTATÍSTICA - IBGE (1984). Folha Guarulhos: mapa topográfico da região sudeste - (SF-23-Y-C-III-4). Rio de Janeiro, IBGE. (Escala 1:50.000). 
INTERNATIONAL COMMITTEE OF TAXONOMY OF VIRUS - ICTV (1995) Virus taxonomy: classification and nomenclature of viruses.. New York, International Union of Microbiological Societies. 586 p. (Archives of virology. Supplementum, 10).

INTERNATIONAL COMMITTEE OF TAXONOMY OF VIRUS - ICTV (2000) Archives of virology. International Union of Microbiological Societies. Disponível em <http://www.life.anu.edu.au/viruses/ICTVdB/43010001.htm>. Acesso em 25 set. 2000.

IRITANI, M.A. (1993) Potencial hidrogeológico da cidade universitária de São Paulo. São Paulo, 97 p. Dissertação (Mestrado) - Instituto de Geociências, Universidade de São Paulo.

KEAREY, P.; BROOKS, M. (1984) An introduction to geophysical exploration. Oxford, Blackwell. 296 p.

KESWICK, B.H. (1984) Sources of groundwater pollution. In: BITTON, G.; GERBA, C.P. (Eds.) Groundwater pollution microbiology. New York, John Wiley \& Sons. p. 39-64.

KESWICK, B.H.; WANG, D.; GERBA, C.P. (1982) The use of microorganisms as groundwater tracers: a review. Ground Water, v. 20, n. 2, p. 142-149.

KRONE, R.B.; MCGAUGHEY, P.H.; GOTAAS, H.B. (1957) Direct recharge of ground water with sewage effluents. Journal of the Sanitary Engineering Division. v. 83, n. SA 4, p. 1335 $1-1335-25$.

KUTTER, E.; KELLENBERGER, E.; CARLSON, K.; EDDY, S.; NEITZEL, J.; MESSINGER, L.; NORTH, J.; GUTTMAN, B. (1994) Effects of bacterial growth conditions and physiology on T4 infection. In: KARAM, J.D. (Ed.). Molecular biology of bacteriophage T4. Washington, American Society for Microbiology. p. 406-418.

LEPSCH, I.F. (1975) Classificação e mapeamento dos solos de São Paulo. In: MONIZ, A.C. (Coord.) (1975) Elementos de pedologia. 2. ed. Rio de Janeiro, Livros Técnicos e Científicos. p. 377-390.

MADIGAN, M.T.; MARTINKO, J.M.; PARKER, J. (1997) Brock biology of microorganisms. 8th ed. New Jersey, Prentice Hall. 986 p.

MARTINS, M.T.; PELLIZARI, V.H.; PACHECO, A.; MYAKI, D.M.; ADAMS, C.; BOSSOLAN, N.R.S.; MENDES, J.M.B.; HASSUDA, S. (1991) Qualidade bacteriológica de águas subterrâneas em cemitérios. Revista de Saúde Pública, v. 25, n. 1, p. 47-52.

MATOS, B.A.; BASTIANON, D.; BATELlO, E.; PACHECO, A.; PELIZZARI, V.; MENDES, J.M. (1998) Contaminação do aqüífero livre em cemitérios: estudo de caso. In: CONGRESSO BRASILEIRO DE ÁGUAS SUBTERRÂNEAS, 10., São Paulo, 1998. Anais. São Paulo, ABAS. 1 CD-ROM.

MATOS, B.A.; PACHECO, A. (2000) Ocorrência de microrganismos no aqüífero freático do cemitério Vila Nova Cachoeirinha, São Paulo. In: CONGRESSO MUNDIAL INTEGRADO DE ÁGUAS SUBTERRÂNEAS, 1., Fortaleza, 2000. Anais. Fortaleza, ABAS. 1 CD-ROM.

MCDOWELL-BOYER, L. M.; HUNT, J. R.; SITAR, N. (1986) Particle transport through porous media. Water Resources Research, n. 22, v. 13, p. 1901-1921. 
MCKAY, L.D.; CHERRY, J.A.; BALES, R.C.; YAHYA, M.T.; GERBA, C.P. (1993) A field example of bacteriophage as tracers of fracture flow. Environmental Science and Technology, v. 27, p. 1075-1079.

MEHNERT, D.U.; STEWIEN, K.E.; HÁRSI, C.M.; QUEIROZ, A.P.S.; CANDEIAS, J.M.G.; CANDEIAS, J.A.N. (1997) Detection of rotavirus in sewage and creek water: efficiency of the concentration method. Mem. Inst. Oswaldo Cruz, v. 92, n. 1, p. 97-100.

MENDES, J.M.B.; PACHECO, A.; HASSUDA, S. (1989) Cemitérios e meio ambiente - a geofísica como método auxiliar na avaliação de sua influência nas águas subterrâneas. In: ENCONTRO NACIONAL DE ESTUDOS SOBRE O MEIO AMBIENTE, 2., Florianópolis, 1989. Anais. Florianópolis, UFSC. v. 1, p. 50-57.

MENEGASSE, L.N. (1991) Estudo hidrogeológico das rochas metassedimentares do Grupo São Roque a NW da Grande São Paulo -critérios para locação de poços profundos. São Paulo, 104 p. Dissertação (Mestrado) - Instituto de Geociências, Universidade de São Paulo.

MENEGASSE VELASQUEZ, L.N. (1996) Efeitos da urbanização sobre o sistema hidrológico: aspectos da recarga no aqüífero freático e escoamento superficial - Área piloto: sub-bacias Sumaré e Pompéia, município de São Paulo. São Paulo, 124 p. Tese (Doutorado) - Instituto de Geociências, Universidade de São Paulo.

MIGLIORINI, R.B. (1994) Cemitérios como fonte de poluição em aqüíferos. Estudo do Cemitério Vila Formosa na bacia sedimentar de São Paulo. São Paulo. 74 p. Dissertação (Mestrado) - Instituto de Geociências, Universidade de São Paulo.

MINISTÉRIO DA SAÚDE (1990) Portaria no. 36, de 19 de janeiro de 1990. Aprova novas normas e padrões de potabilidade da água a serem observados em todo território nacional. Diário Oficial da República Federativa do Brasil, Brasília, DF, 23 jan. 1990.

MINISTÉRIO DA SAÚDE (2001) Portaria no. 1.469, de 29 de dezembro de 2000. Estabelece os procedimentos e responsabilidades relativos ao controle e vigilância da qualidade da água para consumo humano e seu padrão de potabilidade, e dá outras providências. Diário Oficial da República Federativa do Brasil, Brasília, DF, 19 jan. 2001. 22 p.

MIOTTO, S.L. (1990) Aspectos geológico-geotécnicos da determinação da adequabilidade de áreas para a implantação de cemitérios. Rio Claro, 116 p. Dissertação (Mestrado) Instituto de Geociências e Ciências Exatas, Universidade Estadual Paulista.

MOREIRA-NORDEMANN, L.M.; FORTI, M.C.; ANDRADE, F.; ORSINI, C.M.Q. (1985) Composição iônica das chuvas da cidade de São Paulo. In: SIMPÓSIO BRASILEIRO DE HIDROLOGIA E RECURSOS HÍDRICOS, 6., São Paulo, 1985. Anais. São Paulo, Associação Brasileira de Recursos Hídricos e International Association of Hydrological Sciences. v. 3, p. 419-424.

OLIVEIRA, J.B.; CAMARGO, M.N.; ROSSI, M.; CALDERANO FILHO, B. (1999). Mapa pedológico do Estado de São Paulo. Campinas, Instituto Agronômico/ EMBRAPA. (Escala 1:500.000).

ORGANIZACIÓN MUNDIAL DE LA SALUD - OMS (1979) Virus humanos en el agua, aguas servidas y suelo. Ginebra, OMS. p. 1-52. (Serie de Informes Técnicos, n. 639). 
OTTMAN, F. (1987) Créer ou aménager un cimetière. Paris, Moniteur, 161 p.

PACHECO, A. (1986) Os cemitérios como risco potencial para as águas de abastecimento. Revista do Sistema de Planejamento e Administração Metropolitana, n. 17, p. 25-31.

PACHECO (2000) Cemitérios e meio ambiente. São Paulo, 102 p. Tese (Livre Docência) Instituto de Geociências, Universidade de São Paulo.

PACHECO, A.; BATELlO, E. (2000) A influência de fatores ambientais nos fenômenos transformativos em cemitérios. Revista Engenharia e Arquitetura, v.2, n. 1, p. 32-39.

PACHECO, A.; MATOS, B.A. (2000) Cemitérios e meio ambiente. Tecnologias do Ambiente, n. 33 , p. 13-15.

PACHECO, A.; MENDES, J.M.B.; MARTINS, T.; HASSUDA, S.; KIMMELMANN, A.A. (1991) Cemeteries - a potential risk to groundwater. Water Science and Technology, v. 24, n. 11, p. 97-104.

PACHECO, A.; REBOUÇAS, A.C. (1985) Aspectos de proteção sanitária dos poços tubulares no município de São Paulo. Revista Águas Subterrâneas, v. 9, p. 51-58.

PACHECO, A.; SILVA, L.M.; MENDES, J.M.B.; MATOS, B.A. (1999) Resíduos de cemitérios e saúde pública. Revista Limpeza Pública, v. 52, p. 25-27.

PARISOT, E.H. (1983) As águas subterrâneas no centro-oeste do município de São Paulo. São Paulo, 93 p. Dissertação (Mestrado) - Instituto de Geociências, Universidade de São Paulo.

PARK, N.S.; BLANDFORD, T.N.; HUYAKORN, P.S.; LINGAM, R.; KOOL, J. (1994) VIRALT: A modular semi-analytical and numerical model for simulating viral transport in ground water. International Ground Water Modeling Center, version 3.0, 1 diskette 3.5”.

PEKDEGER, A.; MATTHESS, G. (1983) Factors of bacteria and virus transport in groundwater. Environmental Geology, v. 5, n. 2, p. 49-52.

PEQUENO MARINHO, A.M.C. (1998) Contaminação de aqüíferos por instalação de cemitérios. Estudo de caso do Cemitério São João Batista, Fortaleza, 88 p. Dissertação (Mestrado) - Centro de Ciências, Universidade Federal do Ceará.

PERSON, M. (1991) In situ hydraulic conductivity testing at the UNH well field. New Hampshire, Earth Sciences Department, University of New Hampshire (U.S.A.). 8 p. (Notes Groundwater Hydrology 710/810).

POUNDER, D.J. (1995) Postmortem changes and time of death. Disponível em <http:www.dundee.ac.uk.forensicmedicine/llb/timedeath.htm>. Acesso em 3 nov. 2000.

POWELSON, D.K.; GERBA, C.P. (1994) Virus removal from sewage effluents during saturated and unsaturated flow through soil columns. Water Research, v. 28, n. 10, p. 2175-2181.

PREVEDELlO, C.L. (1996) Física do solo. Curitiba, Sociedade Autônoma de Estudos Avançados em Física do Solo. 446 p.

REBOUÇAS, A.C. (1992) Condições de uso e proteção das águas subterrâneas. In: SEMINÁRIO PROBLEMAS GEOLÓGICOS E GEOTÉCNICOS DA REGIÃO 
METROPOLITANA DE SÃO PAULO. São Paulo, 1992. São Paulo, Associação Brasileira de Águas Subterrâneas, Associação Brasileira de Geologia de Engenharia e Sociedade Brasileira de Geologia - Núcleo São Paulo, p. 77-87.

REINACH, H.C. (1984) Projeto Vila Nova Cachoeirinha - construção habitacional por ajuda mútua. In: SEMINARIO INTERNACIONAL PROGRAMA DE ESTUDOS DE VIVIENDA EN AMERICA LATINA, 2., Colômbia, 1984. São Paulo, 86p.

REZENDE, E.C.M. (2000) Metrópole da morte: necrópole da vida. São Paulo, Carthago. 108 p.

RIO DE JANEIRO (Município) (1969) Decreto-Lei no. 88 de 7 de agosto de 1969. Dispõe sobre a criação de cemitérios particulares, dá outras providências. Imprensa Oficial do Estado.

RIO DE JANEIRO (Município) (1970) Decreto "E" no. 3.707 de 6 de fevereiro de 1970. Disciplina a criação, construção e funcionamento de cemitérios tipo tradicional, parque e vertical, bem como estabelece normas para o funcionamento de agências funerárias e casas de artigos funerários, nos termos do Art. 30 do Decreto-Lei no. 88 de 7 de agosto de 1969. Imprensa Oficial do Estado.

ROMERO, J.C. (1970) The movement of bacteria and viruses through porous media. Ground Water, v. 8, n. 2, p. 37-48.

ROSA, F.V.T (1999) Elementos para estudo de viabilidade de projetos de explotação de água mineral. Campinas, 137 p. Dissertação (Mestrado) - Instituto de Geociências, Universidade Estadual de Campinas.

ROSS, J.L.S. (1981) Qualidade da água subterrânea no espaço urbano da grande São Paulo. São Paulo, 120 p. Tese - Faculdade de Filosofia, Letras e Ciências Humanas, Universidade de São Paulo.

ROSS, J.L.S.; MOROZ, I.C. (1997) Mapa geomorfológico do Estado de São Paulo. São Paulo, USP/IPT/FAPESP. (Escala 1:500.000).

SÃO PAULO (Estado) (1991) Código Sanitário: regulamento da promoção, preservação e recuperação da saúde no campo de competência da Secretaria de Estado da Saúde (revisto e atualizado até dezembro de 1990). 4. ed. São Paulo, Imprensa Oficial do Estado. 412 p. (Decreto lei n. 12.342 de 27 de setembro de 1978).

SCHAUB, S.A.; SORBER, C.A. (1976) Viruses on solids in water. In: BERG, G.; BODILY, H.L.; LENNETTE, E.H.; MELNICK, J.L.; METCALF, T.G. (Eds.). Viruses in water. Washington, American Public Health Association. p.128-138.

SCHIJVEN, J.F.; HOOGENBOEZEM, W.; HASSANIZADEH, S.M.; PETERS, J.H. (1999) Modeling removal of bacteriophages MS2 and PRD1 by dune recharge at Castricum, Netherlands. Water Resources Research, v. 35, n. 4, p. 1101-1111.

SCHWABB, K.J.; DE LEON, R.; SOBSEY, M.D. (1995) Concentration and purification of beef extract mock eluates from water samples for the detection of enteroviruses, hepatitis A and Norwalk virus by reverse transcription-PCR. Applied Environmental Microbiology, v. 61, p. 531-537. 
SCHWARTZ, R.C.; MCINNES, K.J.; JUO, A.S.R.; WILDING, L.P.; REDDELL, D.L. (1999) Boundary effects on solute transport in finite soil columns. Water Resources Research, v. 35, n. 3, p. 671-681.

SILVA, L.M. (1998) Cemitérios: fonte potencial de contaminação dos aquíferos livres. In: CONGRESSO LATINO AMERICANO DE HIDROLOGIA SUBTERRÂNEA, 4., Montevideo, 1998. Memórias. Montevideo, ALHSUD. v. 2, p. 667-681.

SILVA, V.R. (2000) Ocupação territorial e qualidade de água subterrânea em maciço fraturado na região de Itaquera, São Paulo-SP. São Paulo, 127 p. Dissertação (Mestrado) - Instituto de Geociências, Universidade de São Paulo.

SIM, Y.; CHRYSIKOPOULOS, C.V. (1995) Analytical models for one-dimensional virus transport in saturated porous media. Water Resources Research, v. 31, n. 5, p. 1429-1437.

SIM, Y.; CHRYSIKOPOULOS, C.V (1996) One-dimensional virus transport in porous media with time-dependent inactivation rate coefficients. Water Resources Research, v. 32, n. 8, p. 2607-2611.

SZIKSZAY, M.; KIMMELMANN, A.A.; HYPOLITO, R.; FIGUEIRA, R.M.; SAMESHIMA, R.H. (1990) Evolution of the chemical composition of water passing through the unsaturated zone to ground water at an experimental site at the university of São Paulo, Brazil. Journal of Hydrology, v. 118, p. 175-190.

TIM, U.S.; MOSTAGHIMI, S. (1991) Model for predicting virus movement through soils. Ground Water, v. 29, n. 2, p. 251-259.

TÔRRES, S.L. (1992a) O problema geo-ambiental da localização de cemitérios em meios urbanos: estudo 2. São Paulo, Fundação de Amparo à Pesquisa do Estado de São Paulo FAPESP. p. 1-33. (Relatório parcial; Processo 91/0360-6).

TÔRRES, S.L. (1992b) O problema geo-ambiental da localização de cemitérios em meios urbano: estudo 2. São Paulo, Fundação de Amparo à Pesquisa do Estado de São Paulo FAPESP. p. 1-32. (Relatório final; Processo 91/0360-6).

VAL, R.R. (1997) Estudo da biodiversidade de colifagos somáticos isolados de ambientes aquáticos e de fezes humanas e animais. São Paulo, 87 p. Dissertação (Mestrado) - Instituto de Ciências Biomédicas, Universidade de São Paulo.

VARNIER, C.; HIRATA, R. (2000) Contaminação da água subterrânea por nitrato no Parque Ecológico do Tietê - São Paulo, Brasil. In: CONGRESSO MUNDIAL INTEGRADO DE ÁGUAS SUBTERRÂNEAS, 1., Fortaleza, 2000. Anais. Fortaleza, ABAS. 1 CD-ROM.

VERA, H.D.; DUMOFF, M. (1974) Culture media. In: LENNETTE, E.H.; SPAULDING, E.H. TRUANT, J.P. (Ed.). Manual of clinical microbiology. 2nd ed. Washington, D.C. American Society for Microbiology. p. 881-929.

VILKER, V.L.; BURGE, W.D. (1980) Adsorption mass transfer model for virus transport in soils. Water Research, v. 14, n. 7, p. 783-790.

WATERLOO HYDROGEOLOGIC (1998) Visual MODFLOW for Windows, version 2.7.1. 5 diskettes 3.5". 
WESNER, G.M.; BAIER, D.C. (1970) Injection of reclaimed wastewater into confined aquifers. Journal of the American Water Works Association, v. 62, p. 203-210.

WIBERG, J.S. (1994) Role of a host chaperonin in T4 growth. In: KARAM, J.D. (Ed.). Molecular biology of bacteriophage T4. Washington, D.C., American Society for Microbiology. p. 480-481.

WILHELM, S.R.; SCHIFF, S.L.; CHERRY, J.A. (1994) Biogeochemical evolution of domestic waste water in septic systems: 1. Conceptual model. Ground Water, v. 32, n. 6, p. 905-916.

WORLD HEALTH ORGANIZATION - WHO (1998) The impact of cemeteries on the environment and public health. An introductory briefing. Copenhagen, Denmark, WHO Regional Office for Europe. 11 p. (Rept. EUR/ICP/EHNA 010401 (A)).

YATES, M.V.; YATES, S.R. (1988) Modeling microbial fate in the subsurface environment. CRC Critical Reviews in Environmental Control. v. 17, n. 4, p. 307-344.

ZELIKSON, R. (1994) Microorganisms and viruses in groundwater. In: ZOLLER, U.(Ed.). Groundwater contamination and control. New York, Marcel Dekker. p. 425-436.

ZHENG, C. (1992) Extension of the method of characteristics for simulation of solute transport in three dimensions. Ground Water, v. 31, n. 3, p. 456-465. 
Nome do arquivo: TESEFINAL

Pasta: $\quad$ C:IDocuments and SettingslclientelConfigurações locais $\backslash$ Temporary Internet Files\Content.IE516XUTO3SN

Modelo: $\quad$ C:IDocuments and SettingslclientelDados de aplicativos $\backslash$ Microsoft $M$ Modelos $\backslash$ Normal.dot

Título:

RESULTADOS

Assunto:

Autor: $\quad$ Bolivar Antunes Matos

Palavras-chave:

Comentários:

Data de criação: $\quad$ 28/3/2001 11:15

Número de alterações:258

Última gravação: $\quad$ 2/7/2001 16:14

Gravado por: Bolivar Antunes Matos

Tempo total de edição: $\quad 2.352$ Minutos

Última impressão: $\quad$ 27/1/2001 16:34

Como a última impressão

Número de páginas: 123

Número de palavras: $\quad 30.206$ (aprox.)

Número de caracteres: 172.176 (aprox.) 
ANEXO 1: LEGISLAÇÃO 


\title{
TRECHOS DO CÓdIGO SANITÁRIO (SÃO PAULO, 1991)
}

\author{
CÓDIGO SANITÁRIO
}

DECRETO N. ${ }^{\circ}$ 12.342, DE 27 DE SETEMBRO DE 1978 REGULAMENTO DA PROMOÇÃO, PRESERVAÇÃO E RECUPERAÇÃO DA SAÚDE NO
CAMPO DE COMPETÊNCIA DA SECRETARIA DE ESTADO DA SAÚDE (REVISTO E ATUALIZADO ATÉ DEZEMBRO DE 1990)

4. ${ }^{\mathrm{a}}$ EDIÇÃO, SÃO PAULO, IMESP, 1991

(....)

\section{SEÇÃO II}

\section{Cemitérios}

Artigo 151 - Os cemitérios serão construídos em áreas elevadas, na contravertente das águas que possam alimentar poços e outras fontes de abastecimento.

Parágrafo único - Em caráter excepcional, serão tolerados, a juízo da autoridade sanitária, cemitérios em regiões planas.

Artigo 152 - Deverão ser isolados, em todo o seu perímetro, por logradouros públicos ou outras áreas abertas, com largura mínima de 15,00 m, em zonas abastecidas por redes de água, e de 30,00 m, em zonas não providas de redes.

Artigo 153 - O nível dos cemitérios deverá ser suficientemente elevado de maneira a assegurar que as sepulturas não sejam inundadas.

Artigo 154 - O nível do lençol freático, nos cemitérios, deverá ficar a 2,00 m, no mínimo, de profundidade.

Parágrafo único - Na dependência das condições das sepulturas, deverá ser feito o rebaixamento suficiente desse nível.

Artigo 155 - Os projetos de cemitérios deverão ser acompanhados de estudos especializados, comprovando a adequabilidade do solo e o nível do lençol freático.

Artigo 156 - Nos cemitérios, deverá haver, pelo menos:

I - local para administração e recepção; 
II - sala de necropsia atendendo aos requisitos exigidos neste Regulamento;

III - depósito de materiais e ferramentas;

IV - vestiários e instalação sanitária para os empregados;

V - instalações sanitárias, para o público, separadas para cada sexo.

Parágrafo único - A autoridade sanitária poderá reduzir as exigências deste artigo em função das limitações sócio-econômicas do município de localização do cemitério.

Artigo 157 - Nos cemitérios, pelo menos $20 \%$ de suas áreas serão destinadas a arborização ou ajardinamento.

$\S 1 .^{\circ}$ - Os jardins sobre jazigos não serão computados para os efeitos deste artigo.

$\S 2 .^{\circ}$ - Nos cemitérios-parque poderá ser dispensada a destinação da área mencionada neste artigo.

Artigo 158 - Os vasos ornamentais não deverão conservar água, a fim de evitar a proliferação de mosquitos.

(...)

\section{LIVRO XII}

Inumações, Exumações, Transladações e Cremações

Artigo 547 - A inumação de pessoas vitimadas por doenças transmissíveis somente poderá ser feita com observância das medidas e cautelas determinadas pela autoridade sanitária.

Parágrafo único - Havendo suspeita de que o óbito foi conseqüente à doença transmissível, a autoridade sanitária poderá, exigir a necropsia para determinar a causa da morte.

Artigo 548 - É proibido o uso de caixões metálicos, ou de madeira revestida, interna ou externamente, com aquele material, excetuando-se os destinados:

I - aos embalsamados;

II - aos exumados;

III - aos cadáveres que não tenham de ser com eles enterrados, sendo obrigatória a desinfecção após o uso.

Parágrafo único - Outros materiais poderão ser utilizados na confecção de caixões, desde que submetidos à aprovação da autoridade sanitária. 
Artigo 549 - Os caixões destinados à cremação de cadáveres deverão satisfazer às seguintes exigências:

I - ser de material de fácil combustão;

II - ter alças removíveis, evitadas quaisquer peças metálicas;

III - não serem pintados, laqueados ou envernizados;

IV - não provocar, quando queimados, poluição atmosférica acima dos padrões vigentes, nem deixar resíduos aglutinados.

Parágrafo único - Os cadáveres deverão ser cremados em caixões individuais, podendo conter, nos casos de óbitos de gestantes, também o feto ou natimorto.

Artigo 550 - O transporte de cadáveres só poderá ser feito em veículo especialmente destinado a esse fim.

Parágrafo único - Os veículos deverão ser de forma a se prestarem à lavagem e desinfecção após o uso, tendo, no local em que pousar o caixão, revestimento de placa metálica ou de outro material impermeável.

Artigo 551 - O prazo mínimo para exumação é fixado em três anos, contados da data do óbito, sendo reduzido para dois anos no caso de criança até a idade de seis anos, inclusive.

$\S 1$ 1 $^{\circ}$ - Nos casos de construção, reconstrução ou reforma dos túmulos, bem como pedido da autoridade judicial ou policial para instruir inquéritos ou, ainda, em caso de interesse público comprovado, poderão ser alterados os prazos referidos neste artigo, a critério da autoridade sanitária.

$\S 2 .^{\circ}$ - O transporte dos restos mortais exumados será feito em caixão funerário adequado, ou em urna metálica, após a autorização da autoridade sanitária.

(....) 
NORMA TÉCNICA L1.040 (CETESB, 1999)

\begin{tabular}{|c|c|}
\hline IMPLANTAÇÃO DE CEMITÉRIOS & $\begin{array}{c}\text { L1.040 } \\
\text { jan/99 }\end{array}$ \\
\hline
\end{tabular}

SUMÁRIO

Pág.

Introdução.

01

1 - Objetivo.

01

2 - Documentos Complementares.

01

3 - Definições

02

4 - Caracterização do Meio Físico.................................................................. 02

5 - Condições Gerais.................................................................................. 03

6 - Condições Específicas.............................................................................. 05

7 - Referências Bibliográficas....................................................................... 06

Introdução

Dentro de uma política ambiental que objetiva preservar o solo e os recursos hídricos superficiais e subterrâneos, ressalta-se a necessidade de normas técnicas para a implantação de empreendimentos com potencial poluidor.

Neste contexto, os cemitérios envolvem uma problemática intrinsecamente vinculada à saúde pública e à qualidade ambiental, dado o comprometimento potencial a que estão sujeitos os solos e as águas.

A CETESB, no cumprimento de suas atribuições como órgão responsável pelo controle ambiental no Estado de São Paulo, por conseguinte, houve por bem elaborar a presente Norma Técnica para a implantação de cemitérios.

\section{1 - Objetivo}

Esta Norma estabelece os requisitos e as condições técnicas para a implantação de cemitérios destinados ao sepultamento no subsolo, no que tange à proteção e à preservação do ambiente, em particular do solo e das águas subterrâneas.

\section{2 - Documentos Complementares}

Na aplicação desta Norma é necessário consultar:

- Ministério da Saúde - Portaria no 36, de 18.01.1990.

- Resolução n ${ }^{\circ} 5$ de 05.08.1993 do Conselho Nacional do Meio Ambiente - CONAMA.

- Norma ABNT NBR 8.036 - Programação de sondagens de simples reconhecimento dos solos para fundação de edifícios - Procedimento

- Norma ABNT NBR 13.895 - Construção de poços de monitoramento e amostragem Procedimento 
- Norma CETESB E15.011 - Sistema de incineração de resíduos de serviços de saúde, portos e aeroportos - Especificação.

- Boletim 04 da ABGE - Ensaios de permeabilidade em solos - Orientações para sua execução no campo (Junho/1996).

3 - Definições

\subsection{Essências nativas}

São espécies vegetais, arbustivas ou arbóreas, naturais de uma dada região geográfica.

\subsection{Necrochorume}

É um neologismo, também conhecido como putrilagem, que designa o líquido resultante da decomposição de cadáveres. Trata-se de uma solução aquosa rica em sais minerais e substâncias orgânicas degradáveis, de cor castanho-acinzentada, mais viscosa que a água, polimerizável, de odor forte e pronunciado, com grau variado de toxicidade e patogenicidade.

4 - Caracterização da Área

\section{1 - Caracterização geográfica}

A área destinada ao cemitério deverá ser localizada geograficamente por meio de demarcação em carta planialtimétrica regional (Cartas FIGBE em escala 1:50.000; Cartas IGC em escalas 1:50.000, 1:25.000 ou 1:10.000; ou outra carta similar).

Esta área deverá, ainda, ser demarcada em levantamento topográfico planialtimétrico e cadastral cuja escala mínima, para áreas superiores a 7 hectares $\left(70.000 \mathrm{~m}^{2}\right)$, será de 1:1.000, com curvas de nível de metro em metro. Para áreas iguais ou inferiores a 7 hectares, a escala mínima será de 1:500, com curvas de nível de metro em metro. Neste levantamento deverão estar representados os atributos encontrados num entorno de $30 \mathrm{~m}$, tais como ruas e equipamentos urbanos.

\section{2 - Caracterização geológica}

A informação básica que deverá constar da caracterização do terreno é o mapeamento geológico básico, ou seja, a descrição das litologias do substrato, com indicação das formações onde se inserem, dados estes obtidos por meio de sondagens mecânicas de reconhecimento adequadamente locadas. Estas sondagens deverão ser realizadas de acordo com a Norma ABNT NBR 8.036 - Programação de sondagens de simples reconhecimento dos solos para fundação de edifícios - Procedimento e seccionar o maciço geológico até atingir o lençol freático (aprofundando-se na zona saturada pelo menos $3 \mathrm{~m}$ ), ou até uma profundidade de10 $\mathrm{m}$ ou impenetrável a percussão. 
[CETESB1]Nessas sondagens serão conduzidos ensaios de permeabilidade e/ou infiltração, conforme Boletim 04 da ABGE - Ensaios de permeabilidade em solos - Orientações para sua execução no campo.

Nos casos de ocorrência ou risco de viabilização no terreno, de erosões, escorregamentos, subsidências ou movimentação de solo, é necessário, também, uma carta geotécnica onde estes processos estejam representados.

\subsection{Caracterização hidrogeológica}

As informações básicas que devem ser apresentadas são: indicação das profundidades dos níveis do aqüífero freático, medidos no fim da estação de cheias, em mapa potenciométrico com indicação do sentido de fluxo das águas subterrâneas e indicação dos atributos existentes num entorno de $30 \mathrm{~m}$, como fontes, surgências, córregos, drenos, poços ou cacimbas de abastecimento de água.

Nos casos em que for comprovado que o nível mais alto do lençol freático (medido no fim da estação de cheias) está a mais de $10 \mathrm{~m}$ de profundidade, não será necessária a apresentação do mapa potenciométrico.

No caso de utilização de método geofísico, este deverá ser devidamente especificado.

\section{5 - Condições Gerais}

a) A área-objeto deverá situar-se a uma distância mínima de cursos d'água (rios, riachos, córregos), bem como de corpos naturais ou artificiais (lagos, lagoas e reservatórios), de acordo com a legislação vigente.

b) Os cemitérios deverão ser implantados onde as condições de fluxo do lençol freático não ensejem a deterioração das condições de potabilidade (Portaria 36/90 do Ministério da Saúde) pré-existentes de captações de água subterrânea.

c) Internamente, o cemitério deverá ser contornado por uma faixa com largura mínima de $5 \mathrm{~m}$, destituída de qualquer tipo de pavimentação ou recobertura de alvenaria, destinada à implantação de uma cortina constituída por árvores e arbustos adequados, preferencialmente de essências nativas. Parte dessa faixa poderá ter $20 \%$ em sua extensão linear destinada a edifícios, sistema viário ou logradouro de uso público, desde que não contrariem a legislação vigente. Caso a faixa interna exceda este valor mínimo, em situações específicas, poderá ser permitida a construção de ossários regulamentares, sistema viário ou outras construções.

d) Deverão ser mantidas as faixas de isolamento previstas na legislação vigente, onde não serão efetuados nenhum sepultamento. 
e) No interior do cemitério, na chamada zona de enterramento ou sepultamento, é aconselhável o plantio de espécies com raízes pivotantes, a fim de evitar invasões de jazigos, destruição do piso e túmulos ou danos às redes de água, de esgoto e drenagem.

f) O perímetro e o interior do cemitério deverão ser providos de um sistema de drenagem adequado e eficiente, além de outros dispositivos (terraceamentos, taludamentos, etc.) destinados a captar, encaminhar e dispor de maneira segura o escoamento das águas pluviais e evitar erosões, alagamentos e movimentos de terra.

g) O subsolo deverá ser constituído por materiais com coeficientes de permeabilidade entre $10^{-3}$ e $10^{-7} \mathrm{~cm} / \mathrm{s}$, na faixa compreendida entre o fundo das sepulturas e o nível do lençol freático(medido no fim da estação de cheias ); ou até $10 \mathrm{~m}$ de profundidade, nos casos em que o lençol freático não for encontrado até este nível. Coeficientes de permeabilidade diferentes só devem ser aceitos, condicionados a estudos geológicos e hidrogeológicos, fundamentados em conjunto com a tecnologia de sepultamento empregada, os quais demonstrem existir uma condição equivalente de segurança, pela profundidade do lençol freático e pelo uso e importância das águas subterrâneas no local, bem como pelas condições de projeto.

h) O nível inferior das sepulturas deverá estar a uma distância de pelo menos 1,5 m acima do mais alto nível do lençol freático (medido no fim da estação de cheias). Distâncias inferiores poderão vir a ser consideradas aceitáveis, condicionadas a estudos geológicos e hidrogeológicos fundamentados em conjunto com a tecnologia de sepultamento empregada, os quais demonstrem existir uma condição equivalente de segurança, por ser o subsolo extremamente favorável à atenuação dos poluentes, em função de sua granulometria, permeabilidade, umidade e condição de aeração, bem como pelas condições de projeto.

i) Caso as condições naturais do terreno não permitam que as distâncias previstas no item anterior sejam obedecidas, o lençol freático deverá ser rebaixado artificialmente através da instalação de um sistema de drenagem subterrânea, convenientemente locado e implantado, tomando-se os devidos cuidados para que sua eficiência não seja comprometida ao longo do tempo.

j) Resíduos sólidos relacionados à exumação dos corpos, tais como urnas e material descartável (luvas, sacos plásticos, etc.) deverão ter, preferencialmente, o mesmo tratamento dado aos resíduos sólidos gerados pelos serviços de saúde, de acordo com a legislação vigente (Resolução CONAMA n o 5, de 1993 e, no caso de incineração local, Norma CETESB E15.011). Se os resíduos sólidos forem enterrados no próprio cemitério, deverá ser usada unicamente a zona de sepultamento com recobrimento mínimo de $0,5 \mathrm{~m}$ de solo. Fica vetado o uso da faixa especificada no item 5.c, para tal finalidade. 


\section{Condições específicas}

a) A implantação e a operação de cemitérios em Áreas de Proteção Ambiental (APAs) ou Áreas de Proteção de Mananciais (APMs) fica condicionada às exigências adicionais e/ou complementares às estabelecidas nesta Norma, em consonância com a legislação ambiental vigente e as especificações da Secretaria do Meio Ambiente e do CONAMA.

b) Áreas com substrato rochoso extremamente vulnerável, tais como zonas de falhamentos, zonas cataclasadas, rochas calcárias ou calcossilicatadas intemperizadas ou com erosão subsuperficial (canais de dissolução, dolinas, cavernas, etc.) deverão ser previamente descartadas ou consideradas com restrições.

c) Caso os estudos geológicos e hidrogeológicos efetuados em âmbito local demonstrem que o aquíffero freático é potencialmente vulnerável a contaminações, o cemitério deverá ser provido de um sistema de poços de monitoramento, instalados em conformidade com a norma vigente (ABNT NBR13.895 - Construção de Poços de monitoramento e Amostragem). Desde que possível, é recomendável a instalação de alguns poços de monitoramento no entorno da área-objeto, estrategicamente localizados a montante e a jusante da área de sepultamento, com relação ao sentido de escoamento freático. Neste caso, os poços deverão ser amostrados e as águas subterrâneas analisadas, antes do início de operação do cemitério, para o estabelecimento da qualidade "em branco" do aqüífero freático, de acordo com os padrões de potabilidade da Portaria $n^{\circ} 36$, do Ministério da Saúde (1990). A cada trimestre, os poços deverão ser amostrados, em conformidade com a norma NBR13.895 e as amostras de água analisadas para os seguintes parâmetros : condutividade elétrica, sólidos totais dissolvidos, dureza total, $\mathrm{pH}$, cor aparente, cloretos, cromo total, ferro total, fosfato total, nitrogênio amoniacal, nitrogênio nitrato, coliformes totais, coliformes fecais e bactérias heterotróficas . Caso ocorram indícios de contaminação, deverão ser analisados novamente os parâmetros de potabilidade estabelecidos na portaria $\mathrm{n}^{\mathbf{o}} 36$ do Ministério da Saúde. 
7. Referências Bibliográficas

DELMONTE, C. Putrefação e Suas Consequências para o Meio Ambiente. Palestra proferida no Primeiro Seminário Nacional Cemitério e Meio Ambiente. São Paulo, jun/95.

HURST, C.J.; GERBA, C.P.; CECH, I. Effects of Environmental Variables and Soil Characteristics on Virus Survival in Soil. Applied and Environmental Microbiology, p. 1067-1079, dec/80.

LANCE, J.C.; GERBA, C.P.. Virus Movement in Soil During Saturated and Unsaturated Flow. Applied and Environmental Microbiology, p.335-337, fev/84.

MAGALHÃES, F.S.P.; MELLO, L.G.F.S.; MOTIDOME, M.J.. Cemeteries and their Impact on the Environment - Cemetery da Paz, São Paulo, Brazil. Trabalho apresentado no "Word Clean Air Congress 1998; Durban, South Africa, set/ 98.

MARTINS, M.T.; PELLIZARI, V.H.; PACHECO, A.; MYAKI, D.M. Qualidade bacteriológica de águas subterrâneas em cemitérios. Revista Saúde Pública. Vol. 25(1), São Paulo, p. 47$52,1991$.

MCCONNELL, L.K.; SIMS, R. C.; BARNETT, B.B.. Reovirus Removal and Inactivation by Slow-Rate Sand Filtration. Applied and Environmental Microbiology, p. 818-825, oct/84.

MELLO, L.G.F.S.; MOTIDOME, M.J.; MAGALHÃES, F.S.P.. Os Cemitérios Poluem? Revista Saneamento Ambiental, n.34 e 35, 1995.

PACHECO, A.; MENDES, J.M.B.; MARTINS, T.; HASSUDA, S.; KIMMELMANN, A. A.. Cemeteries - A Potential Risk to Groundwater. Water Science Technology; Vol. 24(11), p. 97-104, 1991.

PACHECO, Alberto. Os Cemitérios como Risco Potencial para as Águas de Abastecimento. Revista SPAM. EMPLASA nº 17, ago/86.

SILVA, Lezíro M. Cemitérios: Fonte Potencial de Contaminação dos Aqüíferos Livres. $4^{\circ}$ Congresso Latino-Americano de Hidrologia Subterrânea. Montevidéo, Uruguai - ALHSUD $-1998$.

SILVA, Lezíro M. Os Cemitérios na Problemática Ambiental. I Seminário Nacional "Cemitérios e Meio Ambiente", SINCESP e ACEMBRA. São Paulo, jun/95. 
ANEXO 2: SONDAGENS ELÉTRICAS VERTICAIS

E CAMINHAMENTOS ELETROMAGNÉTICOS 


\section{SONDAGENS ELÉTRICAS VERTICAIS}

Tabela A.1 Resistividade da sondagem elétrica vertical 1 (SEV-1)

\begin{tabular}{rrr}
\hline & \multicolumn{2}{c}{ Resistividade (ohm.m) } \\
\cline { 2 - 3 } AB/2 (m) & Modelo & Observado \\
\hline 1,0 & 241,4 & 263,8 \\
1,5 & 270,2 & 306,3 \\
2,2 & 317,3 & 317,0 \\
3,2 & 372,5 & 379,8 \\
4,6 & 413,7 & 424,4 \\
6,8 & 416,3 & 514,9 \\
10,0 & 371,3 & 313,4 \\
14,7 & 306,6 & 295,8 \\
21,5 & 272,5 & 294,7 \\
31,6 & 289,7 & 295,1 \\
46,4 & 336,6 & 346,7 \\
68,1 & 387,8 & 351,8 \\
100,0 & 432,7 & 473,1 \\
146,8 & 467,0 & \\
\hline
\end{tabular}

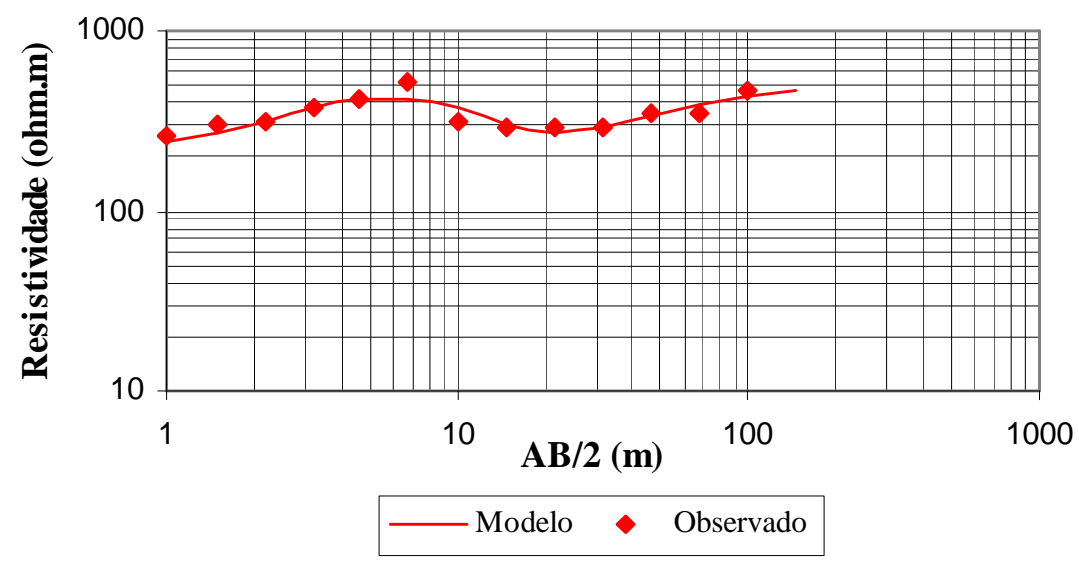

Figura A.1 Sondagem elétrica SEV-1 
Tabela A.2 Resistividade da sondagem elétrica vertical 2 (SEV-2)

\begin{tabular}{rrr}
\hline & \multicolumn{3}{c}{ Resistividade (ohm.m) } \\
\cline { 2 - 3 } AB/2 $(\mathrm{m})$ & Modelo & Observado \\
\hline 1,0 & 232,9 & 251,2 \\
1,5 & 238,4 & 250,7 \\
2,2 & 251,9 & 250,2 \\
3,2 & 278,9 & 266,5 \\
4,6 & 319,1 & 318,5 \\
6,8 & 361,5 & 385,7 \\
10,0 & 395,8 & 400,6 \\
14,7 & 425,9 & 396,1 \\
21,5 & 469,3 & 458,5 \\
31,6 & 541,2 & 533,2 \\
46,4 & 636,4 & 607,7 \\
68,1 & 735,7 & 658,2 \\
100,0 & 823,7 & 935,0 \\
146,8 & 892,1 & \\
\hline
\end{tabular}

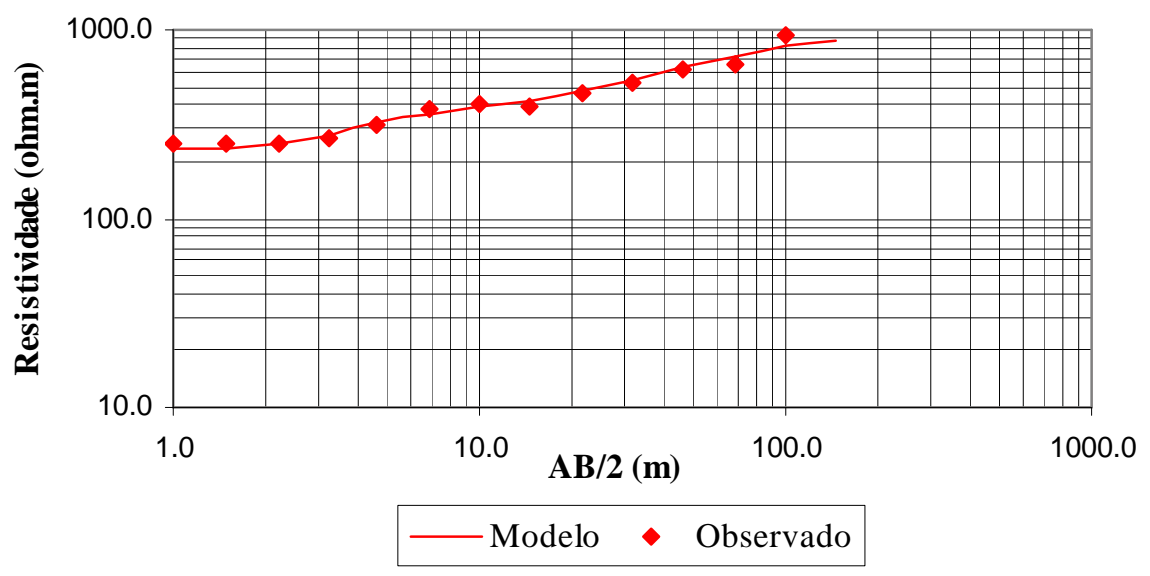

Figura A.2 Sondagem elétrica SEV-2 
Tabela A.3 Resistividade da sondagem elétrica vertical 3 (SEV-3)

\begin{tabular}{rrr}
\hline & \multicolumn{2}{c}{ Resistividade (ohm.m) } \\
\cline { 2 - 3 } AB/2 (m) & Modelo & Observado \\
\hline 1,0 & 94,4 & 94,2 \\
1,5 & 102,1 & 105,4 \\
2,2 & 119,0 & 109,4 \\
3,2 & 149,1 & 159,3 \\
4,6 & 190,7 & 187,8 \\
6,8 & 238,4 & 233,0 \\
10,0 & 285,5 & 282,1 \\
14,7 & 326,5 & 303,8 \\
21,5 & 360,8 & 423,1 \\
31,6 & 394,1 & 405,3 \\
46,4 & 430,9 & 433,6 \\
68,1 & 468,2 & 472,6 \\
100,0 & 499,3 & 502,6 \\
146,8 & 521,2 & 519,3 \\
\hline
\end{tabular}

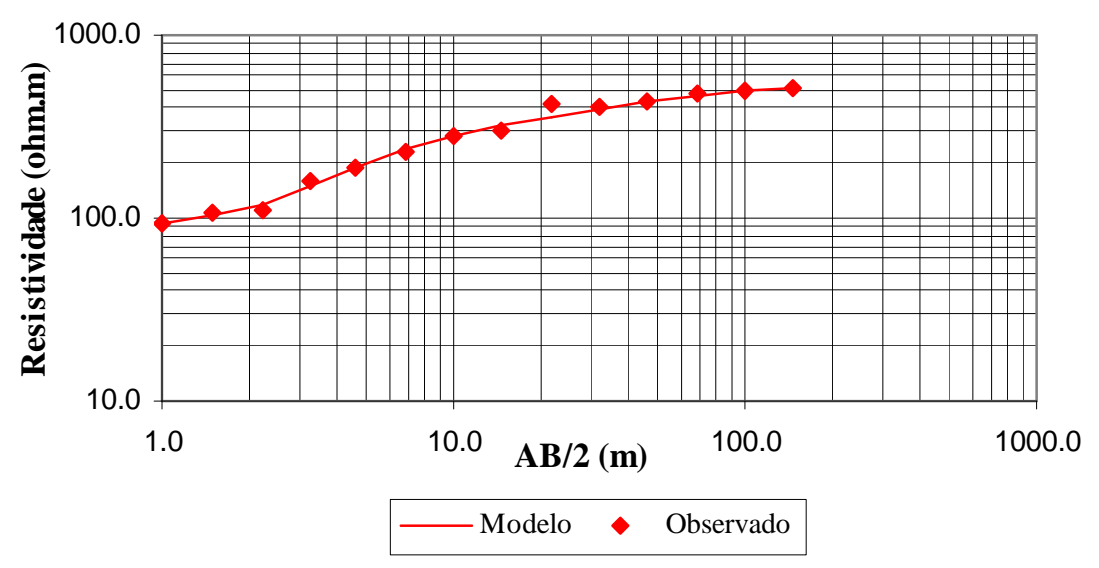

Figura A.3 Sondagem elétrica SEV-3 
Tabela A.4 Resistividade da sondagem elétrica vertical 4 (SEV-4)

\begin{tabular}{|c|c|c|}
\hline \multirow{2}{*}{$\begin{array}{c}\mathrm{AB} / 2 \\
(\mathrm{~m})\end{array}$} & \multicolumn{2}{|c|}{ Resistividade (ohm.m) } \\
\hline & Modelo & Observado \\
\hline 1,0 & 88,9 & 56,5 \\
\hline 1,5 & 87,0 & 70,7 \\
\hline 2,2 & 82,1 & \\
\hline 3,2 & 72,7 & 73,0 \\
\hline 4,6 & 59,6 & 63,8 \\
\hline 6,8 & 47,7 & 44,4 \\
\hline 10,0 & 41,6 & 40,1 \\
\hline 14,7 & 41,6 & 44,0 \\
\hline 21,5 & 47,6 & 53,2 \\
\hline 31,6 & 61,4 & 61,5 \\
\hline 46,4 & 84,1 & 81,3 \\
\hline 68,1 & 115,5 & 121,5 \\
\hline 100,0 & 155,8 & 155,6 \\
\hline 146,8 & 204,7 & \\
\hline
\end{tabular}

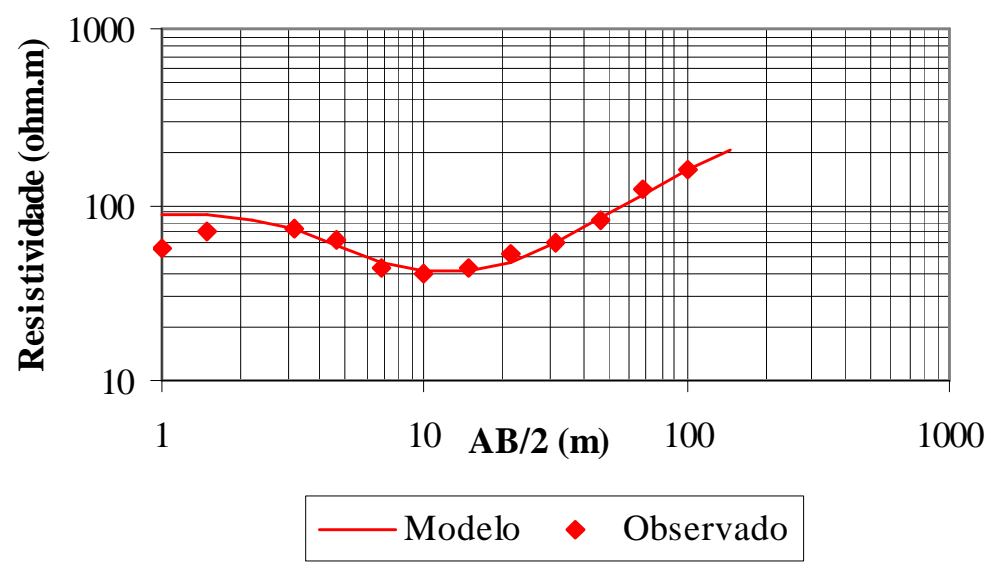

Figura A.4 Sondagem elétrica SEV-4 
Tabela A.5 Resistividade da sondagem elétrica vertical 5 (SEV-5)

\begin{tabular}{rrr}
\hline & \multicolumn{2}{c}{ Resistividade (ohm.m) } \\
\cline { 2 - 3 } AB/2 $(\mathrm{m})$ & Modelo & Observado \\
\hline 1,0 & 249,6 & 230,3 \\
1,5 & 248,9 & 259,2 \\
2,2 & 246,6 & 248,9 \\
3,2 & 240,5 & 243,8 \\
4,6 & 226,3 & 222,3 \\
6,8 & 201,1 & 181,2 \\
10,0 & 172,8 & 160,2 \\
14,7 & 161,0 & 166,8 \\
21,5 & 179,4 & 209,0 \\
31,6 & 222,7 & 229,1 \\
46,4 & 277,9 & 259,0 \\
68,1 & 336,3 & 337,0 \\
100,0 & 391,9 & 392,7 \\
146,8 & 439,3 & \\
\hline
\end{tabular}

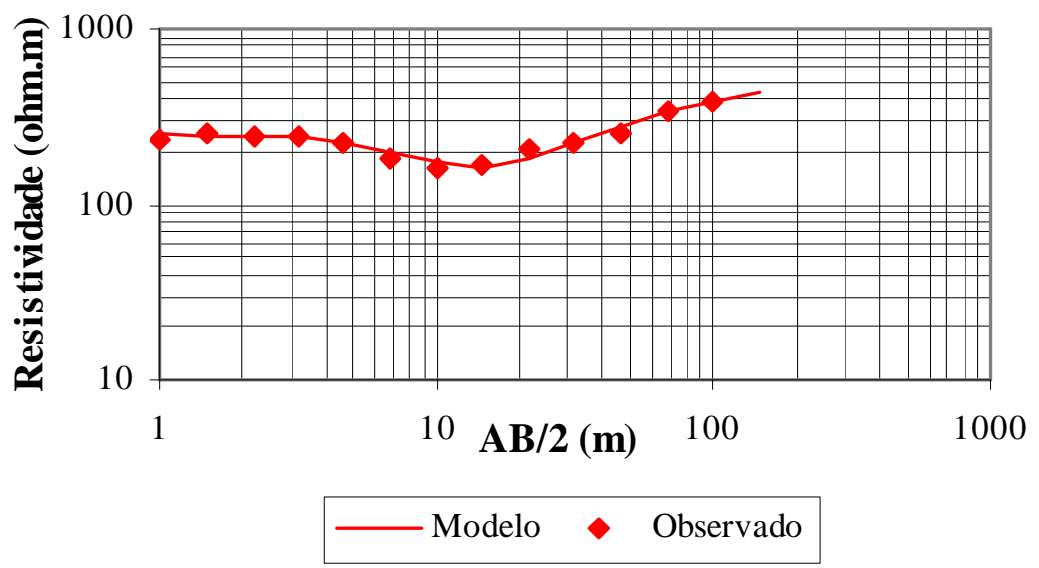

Figura A.5 Sondagem elétrica SEV-5 
Tabela A.6 Resistividade da sondagem elétrica vertical 6 (SEV-6)

\begin{tabular}{rrr}
\hline & \multicolumn{2}{c}{ Resistividade (ohm.m) } \\
\cline { 2 - 3 } AB/2 $(\mathrm{m})$ & Modelo & Observado \\
\hline 1,0 & 186,4 & 219,8 \\
1,5 & 180,0 & 176,7 \\
2,2 & 165,7 & 170,1 \\
3,2 & 142,1 & 138,8 \\
4,6 & 118,8 & 116,6 \\
6,8 & 112,9 & 120,5 \\
10,0 & 125,0 & 131,6 \\
14,7 & 137,4 & 134,4 \\
21,5 & 135,1 & 130,5 \\
31,6 & 119,1 & 130,1 \\
46,4 & 106,5 & 104,1 \\
68,1 & 114,3 & 101,2 \\
100,0 & 140,0 & 173,5 \\
146,8 & 172,5 & \\
\hline
\end{tabular}

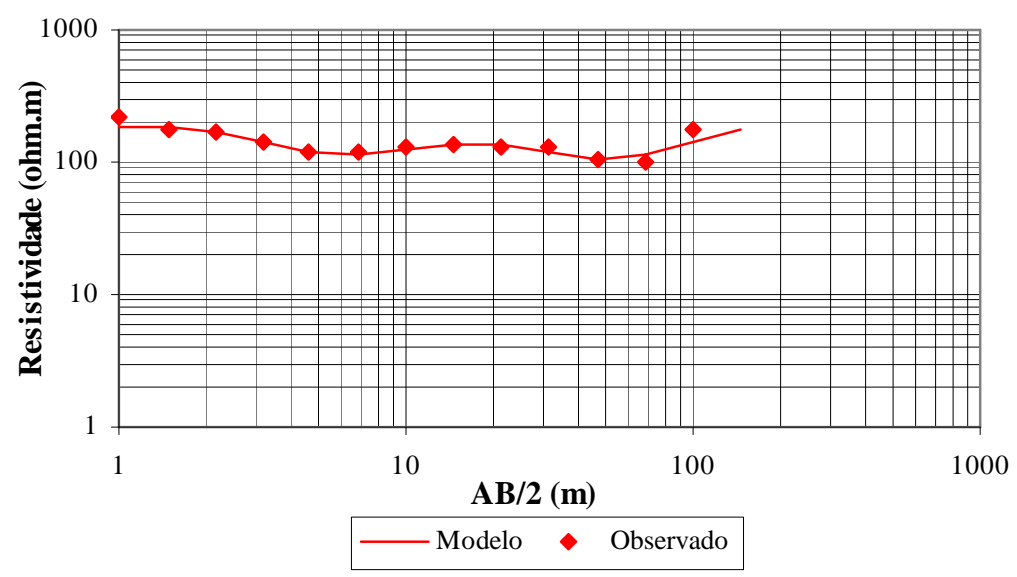

Figura A.6 Sondagem elétrica SEV-6 
Tabela A.7 Resistividade da sondagem elétrica vertical 7 (SEV-7)

\begin{tabular}{rrr}
\hline & \multicolumn{2}{c}{ Resistividade (ohm.m) } \\
\cline { 2 - 3 } AB/2 (m) & Modelo & Observado \\
\hline 1,0 & 446,8 & 471,0 \\
1,5 & 440,6 & 438,7 \\
2,2 & 424,1 & 435,7 \\
3,2 & 387,0 & 375,5 \\
4,6 & 323,7 & 298,6 \\
6,8 & 250,9 & 233,6 \\
10,0 & 201,0 & 218,3 \\
14,7 & 189,7 & 210,4 \\
21,5 & 215,0 & 228,1 \\
31,6 & 275,4 & 243,8 \\
46,4 & 368,2 & 367,8 \\
68,1 & 487,5 & 555,6 \\
100,0 & 628,2 & \\
146,8 & 782,6 & \\
\hline
\end{tabular}

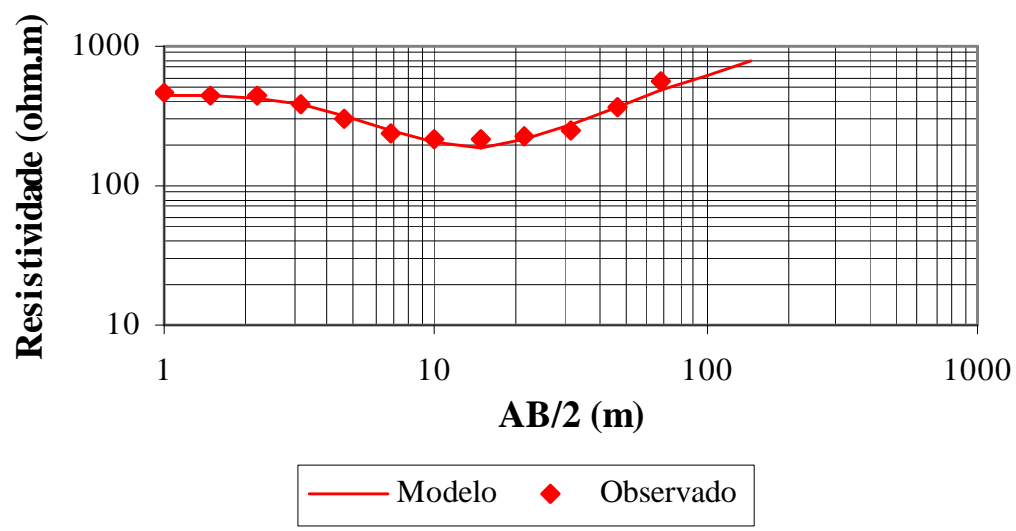

Figura A.7 Sondagem elétrica SEV-7 
Tabela A.8 Resistividade da sondagem elétrica vertical 8 (SEV-8)

\begin{tabular}{rrr}
\hline & \multicolumn{2}{c}{ Resistividade (ohm.m) } \\
\cline { 2 - 3 } AB/2 (m) & Modelo & Observado \\
\hline 1,0 & 468,4 & 376,8 \\
1,5 & 378,6 & 270,9 \\
2,2 & 249,1 & 240,3 \\
3,2 & 132,0 & 138,4 \\
4,6 & 73,6 & 82,1 \\
6,8 & 61,5 & 60,1 \\
10,0 & 68,9 & 62,3 \\
14,7 & 89,8 & 97,4 \\
21,5 & 126,0 & 130,2 \\
31,6 & 179,6 & 149,4 \\
46,4 & 253,9 & 297,2 \\
68,1 & 354,2 & \\
\hline
\end{tabular}

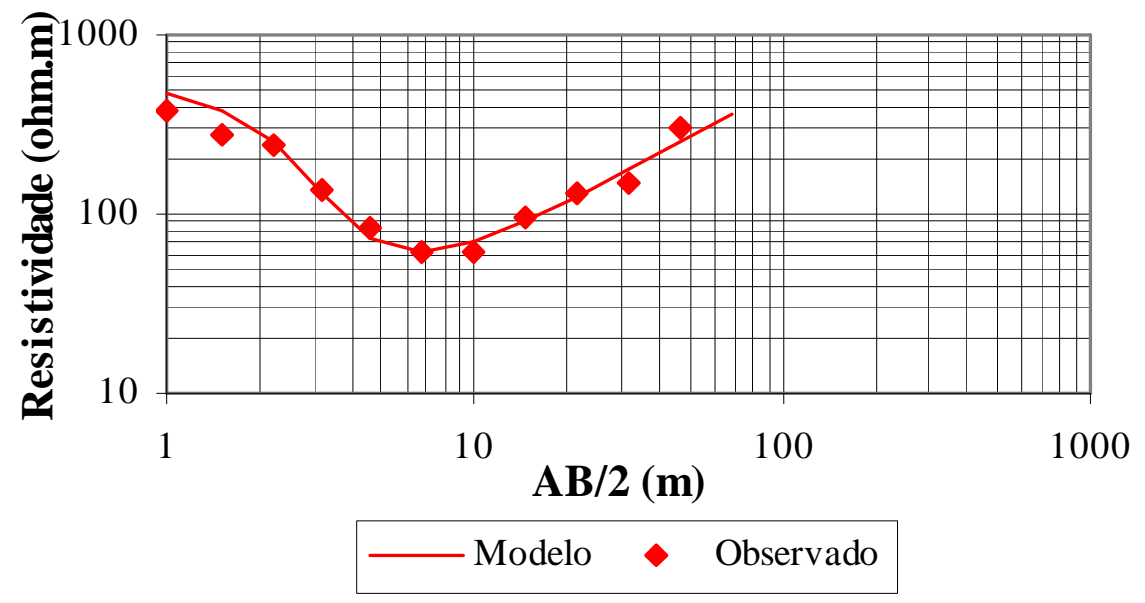

Figura A.8 Sondagem elétrica SEV-8 


\section{ESTUDOS ELETROMAGNÉTICOS}

Tabela A.9 Condutividade aparente do EM-1

\begin{tabular}{lrrr}
\hline \multirow{2}{*}{ Ponto } & \multicolumn{2}{c}{ Condutividade aparente $(\mathbf{m S} / \mathbf{m})$} & \multirow{2}{*}{ Observação } \\
\cline { 2 - 3 } Horizontal & \multicolumn{2}{c}{ Vertical } & \\
\hline 1 & 5 & 5 & \\
2 & 4 & 6 & \\
3 & 4 & 7 & próximo ao poste \\
4 & 3 & 11 & \\
5 & 3 & 9 & \\
6 & 3 & 6 & \\
7 & 3,5 & 13 & \\
8 & 4 & 13 & \\
9 & $*$ & $*$ & poste \\
10 & 5 & 7 & \\
11 & 3 & 2 & \\
12 & 2 & 10 & \\
13 & 2,2 & 5 & \\
14 & 3,2 & 4 & \\
15 & 4 & 7 & \\
16 & 4 & 4,5 & \\
17 & 4 & 6 & \\
18 & 3,5 & 4 & \\
19 & 4 & $*$ &
\end{tabular}

OBSERVAÇÕES: CAMINHAMENTO No. $\underline{01}$

DATA: $\underline{10 /} \underline{03 / 98}, 13: 00$.

RESPONSÁVEIS: Bolivar A. Matos, Douglas Bastianon

Aparelho EM34-3. Distância entre o transmissor e o receptor de 10 m. Separação entre pontos é de $10 \mathrm{~m}$.* Registro fora de escala. 
Tabela A.10 Condutividade aparente do EM-2

\begin{tabular}{lrrl}
\hline \multirow{2}{*}{ Ponto } & \multicolumn{2}{c}{ Condutividade aparente (mS/m) } & \multirow{2}{*}{ Observação } \\
\cline { 2 - 3 } Horizontal & \multicolumn{2}{c}{ Vertical } & \\
\hline 1 & 9 & 3,5 & \\
2 & 7,5 & 2,4 & \\
3 & 6,8 & 4 & \\
4 & 6,8 & 6,8 & \\
5 & 6,4 & 4,4 & rua por trás do santuário \\
6 & 6,4 & 5 & \\
7 & 8 & 7,6 & \\
8 & 8,6 & 7,2 & \\
9 & 6,4 & 4,2 & \\
10 & 8,4 & $*$ & fora da escala \\
11 & 8,0 & 10 & \\
12 & 8,0 & 10,5 & \\
13 & 8 & 11 & \\
14 & 7 & 8 & \\
15 & 9 & 8 & \\
16 & 6 & 8 & \\
17 & 8 & 4 & \\
18 & 8 & 10 & \\
19 & 7,5 & 8 & ao lado do local de \\
20 & 6,5 & 6 & descanso de funcionários \\
& & &
\end{tabular}


Tabela A.11 Condutividade aparente do EM-3

\begin{tabular}{|c|c|c|c|}
\hline \multirow[t]{2}{*}{ Ponto } & \multicolumn{2}{|c|}{ Condutividade aparente $(\mathrm{mS} / \mathrm{m})$} & \multirow[t]{2}{*}{ Observação } \\
\hline & Horizontal & Vertical & \\
\hline 1 & 5 & 7 & \\
\hline 2 & 5 & 6 & \\
\hline 3 & 7 & 5 & \\
\hline 4 & 10 & 7 & \\
\hline 5 & 10 & 9 & \\
\hline 6 & 8 & 5,5 & \\
\hline 7 & 8 & 8 & $\begin{array}{l}\text { rua entre o transmissor e } \\
\text { o receptor }\end{array}$ \\
\hline 8 & 7,5 & 8 & \\
\hline 9 & 8 & 8 & \\
\hline 10 & 10 & 7 & \\
\hline 11 & 10 & 3,5 & ao lado da porta do santuário \\
\hline 12 & 8 & 8,5 & $\begin{array}{l}\text { rua entre o transmissor e } \\
\text { o receptor }\end{array}$ \\
\hline 13 & 11 & 9 & \\
\hline 14 & 9 & 9 & \\
\hline 15 & 7 & 4 & \\
\hline 16 & 7 & 3 & rua asfaltada \\
\hline 17 & 8 & 1 & \\
\hline 18 & 8 & 3 & \\
\hline 19 & 9,5 & 3 & \\
\hline 20 & 8 & 0,5 & ponto mais elevado da linha \\
\hline 21 & 6 & 5 & transmissor na rua asfaltada \\
\hline
\end{tabular}


Tabela A.12 Condutividade aparente do EM-4

\begin{tabular}{lrrl}
\hline \multirow{2}{*}{ Ponto } & Condutividade aparente $(\mathbf{m S} / \mathbf{m})$ & \multirow{2}{*}{ Observação } \\
\cline { 2 - 3 } Horizontal & \multicolumn{2}{c}{ Vertical } & \\
2 & 5 & 6 & \\
3 & 4 & 8 & \\
4 & 4 & 7 & \\
5 & 5 & 8,5 & \\
6 & 5 & 8 & \\
7 & 6 & 7 & \\
8 & 3 & 11 & receptor na rua \\
9 & 4 & 8,5 & \\
10 & 7 & 5,5 & \\
11 & 8 & 6 & \\
12 & 9 & 3 & transmissor em baixo da coberta \\
& & & (pilares metálicos) \\
13 & 9 & 6 & receptor em baixo da coberta \\
& & & (pilares metálicos) \\
14 & 8 & 7 & \\
15 & 5,5 & 1,6 & transmissor na rua após santuário \\
16 & 4,5 & 4,5 & \\
17 & 2,2 & 4,5 & \\
18 & 1,6 & 4,8 & \\
19 & 2 & 3,8 & \\
20 & 3,2 & 3,8 & \\
21 & 5 & 2,8 & transmissor na rua asfaltada \\
\hline CAMINHAMENTO No. 04 & &
\end{tabular}


Tabela A.13 Condutividade aparente do EM-5

\begin{tabular}{lrrl}
\hline \multirow{2}{*}{ Ponto } & \multicolumn{2}{c}{ Condutividade aparente $(\mathbf{m S} / \mathbf{m})$} & \multirow{2}{*}{ Observação } \\
\cline { 2 - 3 } Horizontal & \multicolumn{2}{c}{ Vertical } & \\
2 & 9 & 9 & \\
3 & 8 & 9 & \\
4 & 8 & 8 & \\
5 & 9 & 12 & \\
6 & 9 & 9 & \\
7 & 9 & 9 & transmissor na rua antes do santuário \\
8 & 6 & 12 & receptor na rua antes do santuário \\
9 & 5 & 8 & \\
10 & 5 & 6 & \\
11 & 2,8 & 6 & \\
& 6 & 1,5 & transmissor alinhado com coberta \\
12 & & & (pilar metálico) \\
13 & 3,5 & \\
14 & 4,5 & 0,3 & rua entre transmissor e receptor \\
15 & 6,5 & 5 & \\
16 & 5 & 3 & \\
17 & 4 & 4,5 & transmissor na Quadra 33, túmulo 228 \\
18 & 3,2 & $*$ & $? ? ? ? ? ? ? ? ? ? ?$ caixões metálicos??????? \\
19 & 4,5 & $*$ & $? ? ? ? ? ? ? ? ? ? ?$ caixões metálicos??????? \\
20 & 6 & 1 & $? ? ? ? ? ? ? ? ? ?$ caixões metálicos??????? \\
\hline
\end{tabular}


Tabela A.14 Condutividade aparente do EM-6

\begin{tabular}{|c|c|c|c|}
\hline \multirow[t]{2}{*}{ Ponto } & \multicolumn{2}{|c|}{ Condutividade aparente $(\mathrm{mS} / \mathrm{m})$} & \multirow[t]{2}{*}{ Observação } \\
\hline & Horizontal & Vertical & \\
\hline 1 & 10 & 10 & \\
\hline 2 & 11 & 13 & \\
\hline 3 & 11 & 11 & \\
\hline 4 & 11 & 9 & \\
\hline 5 & 12 & 10 & \\
\hline 6 & 12 & 0,15 & $\begin{array}{l}\text { transmissor em cima do } \\
\text { túmulo } 294 \text {, quadra } 31\end{array}$ \\
\hline 7 & 10 & $*$ & \\
\hline 8 & 2 & $*$ & \\
\hline 9 & 6 & 5 & \\
\hline 10 & 4 & 9 & \\
\hline 11 & 6 & 6 & \\
\hline 12 & 5 & 7 & transmissor alinhado com cobertura \\
\hline 13 & 6 & 5 & \\
\hline 14 & 5 & 4 & $\begin{array}{l}\text { receptor na Q34, T195 } \\
\text { transmissor na rua após santuário }\end{array}$ \\
\hline 15 & 4 & 6 & \\
\hline 16 & 4 & 4 & \\
\hline 17 & 2,8 & 4,2 & \\
\hline 18 & 3 & 0,7 & \\
\hline 19 & 4 & $*$ & \\
\hline 20 & 4 & 3 & \\
\hline 21 & 4 & 5 & \\
\hline
\end{tabular}


Tabela A.15 Condutividade aparente do EM-7

\begin{tabular}{|c|c|c|c|}
\hline \multirow[t]{2}{*}{ Ponto } & \multicolumn{2}{|c|}{ Condutividade aparente (mS/m) } & \multirow[t]{2}{*}{ Observação } \\
\hline & Horizontal & Vertical & \\
\hline 1 & 4,2 & 5,2 & saída à uns $13 \mathrm{~m}$ da linha anterior \\
\hline 2 & 2,2 & 2,6 & \\
\hline 3 & 3,9 & 6,2 & \\
\hline 4 & 5,6 & $*$ & \\
\hline 5 & 5,2 & 3 & \\
\hline 6 & 4,8 & 4,2 & \\
\hline 7 & 4 & 5,2 & rua entre transmissor e receptor \\
\hline 8 & 5 & 6,2 & \\
\hline 9 & 6 & 1,6 & \\
\hline 10 & 5 & 6,2 & \\
\hline 11 & 5,2 & 7 & \\
\hline 12 & 7 & 7 & rua alinhada com coberta \\
\hline 13 & 7 & 8 & \\
\hline 14 & 6 & 10 & \\
\hline 15 & 7 & 12 & \\
\hline 16 & 7 & 13 & \\
\hline 17 & 10 & 12 & \\
\hline 18 & 12 & 13 & \\
\hline 19 & 15 & 14 & \\
\hline 20 & 15 & 11 & \\
\hline 21 & 15 & 6 & \\
\hline 22 & 11 & 15 & \\
\hline 23 & 11 & 14 & transmissor na rua \\
\hline
\end{tabular}


Tabela A.16 Condutividade aparente do EM-8

\begin{tabular}{|c|c|c|c|}
\hline \multirow[t]{2}{*}{ Ponto } & \multicolumn{2}{|c|}{ Condutividade aparente $(\mathrm{mS} / \mathrm{m})$} & \multirow[t]{2}{*}{ Observação } \\
\hline & Horizontal & Vertical & \\
\hline 1 & 13 & 15 & \\
\hline 2 & 13 & 13 & \\
\hline 3 & 13 & 17 & \\
\hline 4 & 14 & 14 & \\
\hline 5 & 14 & 14 & \\
\hline 6 & 13 & 14 & \\
\hline 7 & 12 & 14 & \\
\hline 8 & 12 & 14 & \\
\hline 9 & 11 & 11 & \\
\hline 10 & 10,5 & 11 & \\
\hline 11 & 11 & 9 & \\
\hline 12 & 7 & 6 & \\
\hline 13 & 7 & 5 & receptor alinhado com coberta \\
\hline 14 & 5 & 4 & $\begin{array}{l}\mathrm{Rx} \\
\text { monte à frente }\end{array}$ \\
\hline 15 & 4 & 7 & transmissor na rua \\
\hline 16 & 3 & 4 & \\
\hline 17 & 2,4 & 4 & \\
\hline 18 & 3 & 4 & \\
\hline 19 & 1,4 & 4 & \\
\hline 20 & 1,8 & 6,5 & \\
\hline 21 & 3 & 5,8 & rua \\
\hline
\end{tabular}


Tabela A.17 Condutividade aparente do EM-9

\begin{tabular}{|c|c|c|c|}
\hline \multirow[t]{2}{*}{ Ponto } & \multicolumn{2}{|c|}{ Condutividade aparente (mS/m) } & \multirow[t]{2}{*}{ Observação } \\
\hline & Horizontal & Vertical & \\
\hline 1 & 6 & 1,6 & \\
\hline 2 & 3,8 & 3 & \\
\hline 3 & 4 & 5 & \\
\hline 4 & 3 & 6,8 & \\
\hline 5 & 3 & 8 & \\
\hline 6 & 6 & 8 & \\
\hline 7 & 7 & 7 & \\
\hline 8 & 9 & 12 & \\
\hline 9 & 9 & 8 & receptor e transmissor no "vale" \\
\hline 10 & 18 & 6 & $\begin{array}{l}\text { córrego ao lado }(3 \mathrm{~m}) \text {, bueiro, } \\
\text { parte mais baixa, pouco entulho }\end{array}$ \\
\hline 11 & 22 & 8 & transmissor no entulho \\
\hline 12 & 20 & 13 & receptor no entulho \\
\hline 13 & 25 & 11 & receptor ao norte do entulho \\
\hline 14 & 25 & 16 & \\
\hline 15 & 24 & 19 & \\
\hline 16 & 23 & 15 & \\
\hline 17 & 23 & 13 & \\
\hline 18 & 21 & 11 & \\
\hline 19 & 16 & 13 & \\
\hline 20 & 14 & 18 & \\
\hline 21 & 13 & 16 & \\
\hline 22 & 14 & 16 & $\begin{array}{l}\text { transmissor alinhado com o início. } \\
\text { Chegada à } 17 \mathrm{~m} \text { da linha } 8\end{array}$ \\
\hline
\end{tabular}


Tabela A.18 Condutividade aparente do EM-10

\begin{tabular}{|c|c|c|c|}
\hline \multirow[t]{2}{*}{ Ponto } & \multicolumn{2}{|c|}{ Condutividade aparente (mS/m) } & \multirow[t]{2}{*}{ Observação } \\
\hline & Horizontal & Vertical & \\
\hline 1 & 3,5 & 4 & \\
\hline 2 & 3,5 & 3,5 & \\
\hline 3 & 2,8 & 5 & \\
\hline 4 & 2,8 & 12 & \\
\hline 5 & 3 & 19 & \\
\hline 6 & 3 & 22 & \\
\hline 7 & 4 & 32 & \\
\hline 8 & 5 & 40 & \\
\hline 9 & 5 & 48 & \\
\hline 10 & 4 & 36 & \\
\hline 11 & 3 & & $\begin{array}{l}\text { caminhamento interrompido devido } \\
\text { às leituras de altas condutividades provocadas } \\
\text { pelas ruas em concreto armado }\end{array}$ \\
\hline
\end{tabular}

OBSERVAÇÕES: CAMINHAMENTO No. $\underline{10}$

DATA: 02/ 04/ 98, 13:00.

Aparelho EM34-3. Distância entre o transmissor e o receptor de $10 \mathrm{~m}$. Separação entre pontos é de $20 \mathrm{~m}$.

Tabela A.19 Condutividade aparente do EM-11

\begin{tabular}{|c|c|c|c|}
\hline \multirow[t]{2}{*}{ Ponto } & \multicolumn{2}{|c|}{ Condutividade aparente $(\mathrm{mS} / \mathrm{m})$} & \multirow[t]{2}{*}{ Observação } \\
\hline & Horizontal & Vertical & \\
\hline 1 & 4 & 3 & receptor na rua da borda \\
\hline 2 & 6 & 4 & \\
\hline 3 & 5 & 6 & \\
\hline 4 & 3 & $*$ & transmissor em cruzamento de rua larga \\
\hline 5 & 6 & 8 & \\
\hline 6 & 5 & 8 & \\
\hline 7 & 4 & 7 & rua entre transmissor e receptor \\
\hline 8 & 5 & 6 & \\
\hline 9 & 5 & 7 & rua entre transmissor e receptor \\
\hline 10 & 4 & 7 & \\
\hline 11 & 6 & 8 & \\
\hline 12 & 5 & 6 & \\
\hline 13 & 5 & 6 & \\
\hline 14 & 4 & 4 & \\
\hline 15 & 4 & 4 & avenida entre transmissor e receptor \\
\hline
\end{tabular}


Tabela A.20 Condutividade aparente do EM-12

\begin{tabular}{|c|c|c|c|}
\hline \multirow[t]{2}{*}{ Ponto } & \multicolumn{2}{|c|}{ Condutividade aparente (mS/m) } & \multirow[t]{2}{*}{ Observação } \\
\hline & Horizontal & Vertical & \\
\hline 1 & 4 & 5 & \\
\hline 2 & 4 & 5 & \\
\hline 3 & 8 & 5 & \\
\hline 4 & 15 & 7 & \\
\hline 5 & 18 & 13 & \\
\hline 6 & 18 & 19 & receptor em frente "água" \\
\hline 7 & 18 & 20 & buraco ao lado \\
\hline 8 & 15 & 15 & $\begin{array}{l}\text { receptor em frente ao portão, } \\
\text { ao lado do piezômetro }\end{array}$ \\
\hline 9 & 8 & 10 & \\
\hline 10 & 4 & 11 & \\
\hline 11 & 4 & 8 & \\
\hline 12 & 4 & 8 & \\
\hline 13 & 4 & 7 & \\
\hline 14 & 3 & 9 & início da subida \\
\hline 15 & 2 & 9 & curva atrás do hospital \\
\hline
\end{tabular}

CAMINHAMENTO No. $\underline{12} \quad$ DATA: 02/ 04/ 98 .

Tabela A.21 Condutividade aparente do EM-13

\begin{tabular}{|c|c|c|c|}
\hline \multirow[t]{2}{*}{ Ponto } & \multicolumn{2}{|c|}{ Condutividade aparente $(\mathrm{mS} / \mathrm{m})$} & \multirow[t]{2}{*}{ Observação } \\
\hline & Horizontal & Vertical & \\
\hline 1 & 4 & 5 & início próximo à avenida \\
\hline 1,5 & 4 & 5 & \\
\hline 2 & 4 & 4 & \\
\hline 3 & 4 & 6 & \\
\hline 4 & 4 & 8 & \\
\hline 5 & 4 & 10 & transmissor em rua na direção do santuário \\
\hline 6 & 4 & 11 & \\
\hline 7 & 5 & 12 & \\
\hline 8 & 5 & 13 & transmissor em frente à "praça" \\
\hline 9 & 4 & 21 & $\begin{array}{l}\text { anomalia aumentando com a } \\
\text { calçada se aproximando, } \\
\text { caminhamento interrompido }\end{array}$ \\
\hline
\end{tabular}

Repetição da linha 10, mas seguindo a grama e não a calçada. Aparelho EM34-3. Distância entre o transmissor e o receptor de $10 \mathrm{~m}$. Separação entre pontos é de $20 \mathrm{~m}$. 
Tabela A.22 Condutividade aparente do EM-14

\begin{tabular}{|c|c|c|c|}
\hline \multirow[t]{2}{*}{ Ponto } & \multicolumn{2}{|c|}{ Condutividade aparente $(\mathrm{mS} / \mathrm{m})$} & \multirow[t]{2}{*}{ Observação } \\
\hline & Horizontal & Vertical & \\
\hline 1 & 6 & 4 & receptor na borda da avenida \\
\hline 2 & 17 & 7 & $?$ \\
\hline 3 & 4 & $*$ & receptor na rua que desce \\
\hline 3,5 & 6 & 17 & \\
\hline 4 & 6 & 11 & \\
\hline 5 & 5 & 12 & \\
\hline 6 & 5 & 9 & rua entre receptor e transmissor \\
\hline 7 & 5 & 10 & \\
\hline 8 & 6 & 11 & \\
\hline 9 & 5 & 11 & \\
\hline 10 & 6 & 11 & \\
\hline 11 & 7 & 15 & \\
\hline 12 & 4 & $*$ & receptor na rua \\
\hline 12,5 & 5 & 11 & \\
\hline 13 & $*$ & 7 & transmissor na avenida \\
\hline 14 & 4 & 7 & \\
\hline 15 & 4 & $*$ & \\
\hline
\end{tabular}

Tabela A.23 Condutividade aparente do EM-15

\begin{tabular}{|c|c|c|c|}
\hline \multirow[t]{2}{*}{ Ponto } & \multicolumn{2}{|c|}{ Condutividade aparente (mS/m) } & \multirow[t]{2}{*}{ Observação } \\
\hline & Horizontal & Vertical & \\
\hline 1 & 8 & 7 & \\
\hline 2 & 7 & 10 & \\
\hline 3 & 15 & 17 & nível d'água à $30 \mathrm{~cm}$ \\
\hline 4 & 18 & 19 & \\
\hline 5 & 13 & 26 & \\
\hline 6 & 9 & 21 & \\
\hline 7 & 9 & 13 & \\
\hline 8 & 8 & 70 & transmissor na calçada \\
\hline 9 & 7 & 29 & receptor à $3 \mathrm{~m}$ da calçada \\
\hline 10 & 3 & 17 & \\
\hline 11 & 4 & 17 & caixões metálicos ????????? \\
\hline 12 & 0,3 & 9 & \\
\hline 13 & 5 & 7 & \\
\hline 14 & 3 & 8 & \\
\hline 15 & 6 & $*$ & \\
\hline
\end{tabular}


ANEXO 3: TESTES TIPO SLUG 


\section{TESTES TIPO SLUG}

Tabela A.24 Teste slug no poço P1

\begin{tabular}{|c|c|c|}
\hline \multicolumn{3}{|c|}{$\begin{array}{l}\text { TempoNível d' água (H-h)/(H-Ho) } \\
\begin{array}{ll}(\min ) & (\mathrm{m})\end{array}\end{array}$} \\
\hline 0,00 & 2,767 & 1,001 \\
\hline 0,50 & 2,730 & 0,844 \\
\hline 0,75 & 2,700 & 0,717 \\
\hline 1,33 & 2,670 & 0,591 \\
\hline 1,58 & 2,650 & 0,506 \\
\hline 2,00 & 2,640 & 0,464 \\
\hline 2,33 & 2,630 & 0,422 \\
\hline 2,50 & 2,625 & 0,401 \\
\hline 3,00 & 2,615 & 0,359 \\
\hline 3,25 & 2,610 & 0,338 \\
\hline 3,92 & 2,590 & 0,253 \\
\hline 4,50 & 2,585 & 0,232 \\
\hline 5,00 & 2,575 & 0,190 \\
\hline 5,50 & 2,575 & 0,190 \\
\hline 6,33 & 2,570 & 0,169 \\
\hline 7,00 & 2,560 & 0,127 \\
\hline 7,50 & 2,557 & 0,114 \\
\hline 8,00 & 2,555 & 0,105 \\
\hline 9,00 & 2,553 & 0,097 \\
\hline 10,00 & 2,540 & 0,042 \\
\hline 11,00 & 2,537 & 0,030 \\
\hline 12,00 & 2,536 & 0,025 \\
\hline 13,00 & 2,535 & 0,021 \\
\hline 14,00 & 2,532 & 0,008 \\
\hline 15,00 & 2,531 & 0,004 \\
\hline 15,50 & 2,531 & 0,004 \\
\hline 16,50 & 2,531 & 0,004 \\
\hline
\end{tabular}

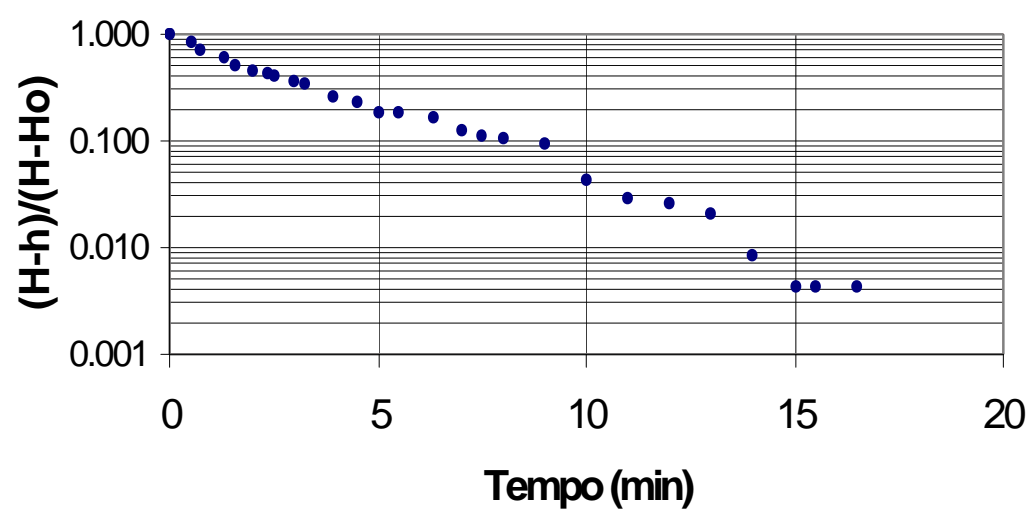

Figura A.9 Recuperação no poço P1

$T_{0}=3 \mathrm{~min}$ 
Tabela A.25 Teste slug no poço P2

\begin{tabular}{crr}
\hline $\begin{array}{c}\text { TempoNível d' água(H-h)/(H-Ho) } \\
\text { (min) }\end{array}$ & $(\mathrm{m})$ & \\
\hline 0,00 & 4,172 & 1,001 \\
0,83 & 4,115 & 0,759 \\
1,17 & 4,115 & 0,759 \\
1,50 & 4,115 & 0,759 \\
1,83 & 4,114 & 0,755 \\
2,08 & 4,110 & 0,738 \\
2,83 & 4,109 & 0,734 \\
3,00 & 4,109 & 0,734 \\
4,00 & 4,104 & 0,713 \\
5,00 & 4,100 & 0,696 \\
6,00 & 4,099 & 0,692 \\
7,00 & 4,097 & 0,684 \\
8,00 & 4,097 & 0,684 \\
10,00 & 4,093 & 0,667 \\
15,00 & 4,085 & 0,633 \\
20,50 & 4,070 & 0,570 \\
25,00 & 4,060 & 0,527 \\
30,00 & 4,005 & 0,295 \\
\hline
\end{tabular}

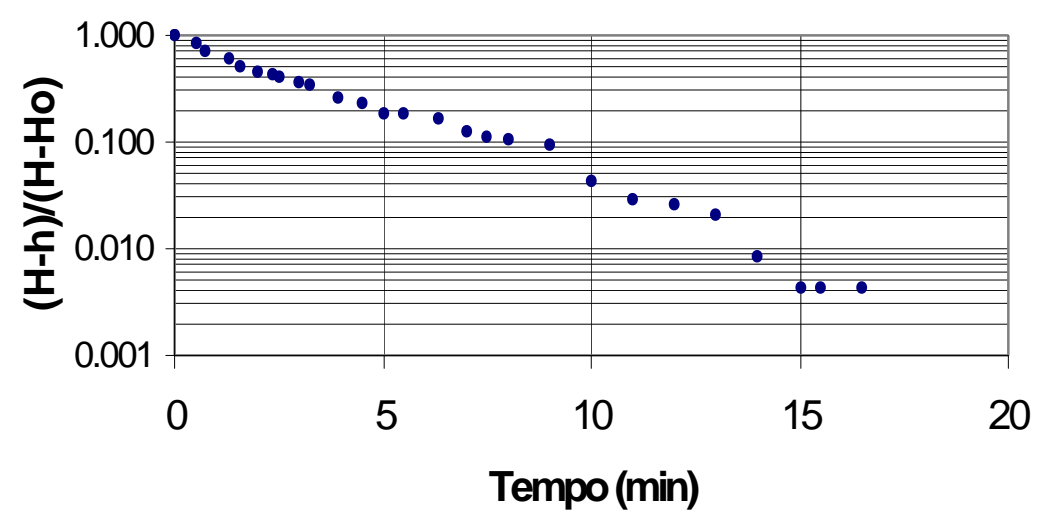

Figura A.10 Recuperação no poço P2 $T_{0}=40 \mathrm{~min}$ 
Tabela A.26 Teste slug no poço P3

\begin{tabular}{|c|c|c|}
\hline $\begin{array}{l}\text { Tempol } \\
\text { (min) }\end{array}$ & $\begin{array}{l}\text { ld' água } \\
\text { (m) }\end{array}$ & H-Ho) \\
\hline 0,00 & 4,350 & 1,001 \\
\hline 1,00 & 4,345 & 0,979 \\
\hline 2,00 & 4,344 & 0,975 \\
\hline 3,50 & 4,322 & 0,882 \\
\hline 5,50 & 4,315 & 0,852 \\
\hline 7,00 & 4,297 & 0,776 \\
\hline 8,00 & 4,225 & 0,473 \\
\hline 9,00 & 4,235 & 0,515 \\
\hline 10,00 & 4,220 & 0,451 \\
\hline 11,00 & 4,220 & 0,451 \\
\hline 12,00 & 4,205 & 0,388 \\
\hline 13,00 & 4,200 & 0,366 \\
\hline 15,00 & 4,180 & 0,283 \\
\hline 17,50 & 4,170 & 0,241 \\
\hline 21,00 & 4,155 & 0,177 \\
\hline 27,00 & 4,145 & 0,135 \\
\hline 30,00 & 4,140 & 0,114 \\
\hline 34,50 & 4,135 & 0,093 \\
\hline
\end{tabular}

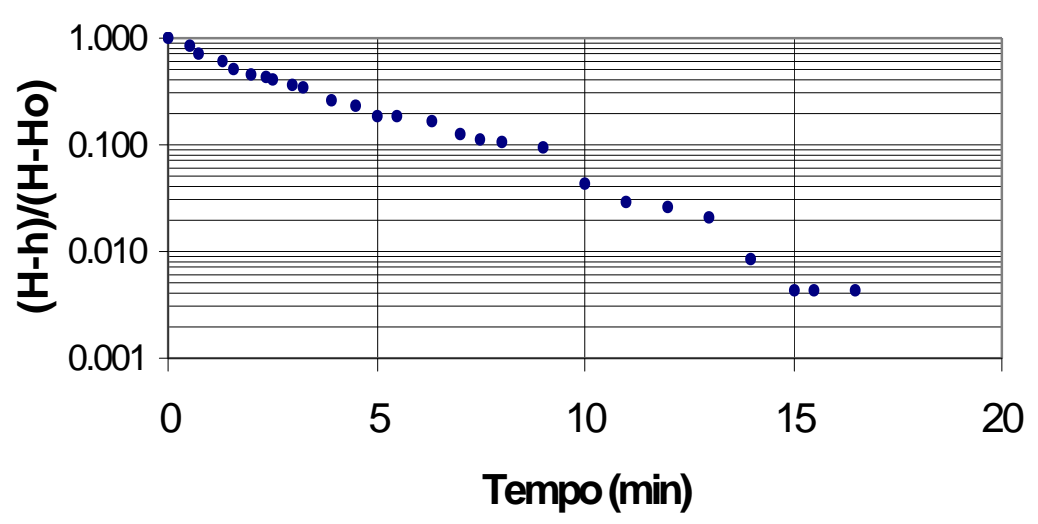

Figura A.11 Recuperação no poço P3

$T_{0}=13,3 \mathrm{~min}$ 
Tabela A.27 Teste slug no poço P4

\begin{tabular}{|c|c|c|}
\hline \multicolumn{3}{|c|}{$\begin{array}{l}\text { TempoNível d'água (H-h)/(H-Ho) } \\
\begin{array}{ll}(\min ) & (\mathrm{m})\end{array}\end{array}$} \\
\hline 0,00 & 4,687 & 1,001 \\
\hline 0,83 & 4,650 & 0,844 \\
\hline 1,17 & 4,645 & 0,823 \\
\hline 1,50 & 4,635 & 0,781 \\
\hline 1,83 & 4,630 & 0,759 \\
\hline 2,00 & 4,628 & 0,751 \\
\hline 2,50 & 4,625 & 0,738 \\
\hline 2,83 & 4,622 & 0,726 \\
\hline 3,50 & 4,615 & 0,696 \\
\hline 3,67 & 4,615 & 0,696 \\
\hline 3,75 & 4,615 & 0,696 \\
\hline 4,00 & 4,610 & 0,675 \\
\hline 4,50 & 4,601 & 0,637 \\
\hline 5,50 & 4,597 & 0,620 \\
\hline 6,00 & 4,597 & 0,620 \\
\hline 7,00 & 4,585 & 0,570 \\
\hline 8,00 & 4,585 & 0,570 \\
\hline 9,00 & 4,570 & 0,506 \\
\hline 10,00 & 4,570 & 0,506 \\
\hline 12,00 & 4,550 & 0,422 \\
\hline 12,50 & 4,540 & 0,380 \\
\hline 13,00 & 4,540 & 0,380 \\
\hline 14,00 & 4,530 & 0,338 \\
\hline 15,50 & 4,520 & 0,295 \\
\hline 17,00 & 4,515 & 0,274 \\
\hline 20,00 & 4,500 & 0,211 \\
\hline 23,00 & 4,490 & 0,169 \\
\hline 25,00 & 4,485 & 0,148 \\
\hline 32,50 & 4,465 & 0,063 \\
\hline
\end{tabular}

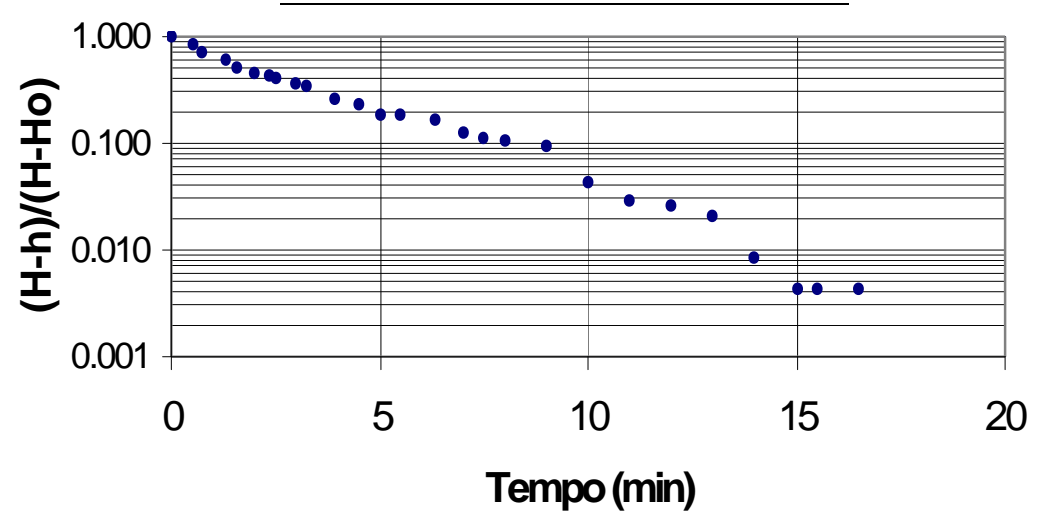

Figura A.12 Recuperação no poço P4

$T_{0}=13 \mathrm{~min}$ 
Tabela A.28 Teste slug no poço P5

\begin{tabular}{|c|c|c|}
\hline \multicolumn{3}{|c|}{$\begin{array}{l}\text { TempoNível d' água (H-h)/(H-Ho) } \\
\begin{array}{ll}\text { (min) } & (\mathrm{m})\end{array}\end{array}$} \\
\hline 0,00 & 4,833 & $\overline{1,001}$ \\
\hline 0,30 & 4,670 & 0,133 \\
\hline 0,35 & 4,661 & 0,085 \\
\hline 0,42 & 4,661 & 0,085 \\
\hline 0,50 & 4,660 & 0,080 \\
\hline 0,57 & 4,659 & 0,074 \\
\hline 0,63 & 4,659 & 0,074 \\
\hline 0,70 & 4,659 & 0,074 \\
\hline 0,80 & 4,658 & 0,069 \\
\hline 0,92 & 4,658 & 0,069 \\
\hline 0,98 & 4,658 & 0,069 \\
\hline 1,07 & 4,658 & 0,069 \\
\hline 1,33 & 4,657 & 0,064 \\
\hline 1,48 & 4,657 & 0,064 \\
\hline 1,70 & 4,657 & 0,064 \\
\hline 1,80 & 4,657 & 0,064 \\
\hline 2,00 & 4,656 & 0,059 \\
\hline 2,12 & 4,656 & 0,059 \\
\hline 2,22 & 4,656 & 0,059 \\
\hline 2,82 & 4,655 & 0,053 \\
\hline 3,30 & 4,654 & 0,048 \\
\hline 3,48 & 4,654 & 0,048 \\
\hline 4,03 & 4,653 & 0,043 \\
\hline 4,45 & 4,653 & 0,043 \\
\hline 4,72 & 4,653 & 0,043 \\
\hline 5,72 & 4,652 & 0,037 \\
\hline 6,53 & 4,651 & 0,032 \\
\hline 10,18 & 4,651 & 0,032 \\
\hline 12,03 & 4,651 & 0,032 \\
\hline 14,13 & 4,650 & 0,027 \\
\hline 16,60 & 4,649 & 0,021 \\
\hline 18,92 & 4,648 & 0,016 \\
\hline
\end{tabular}

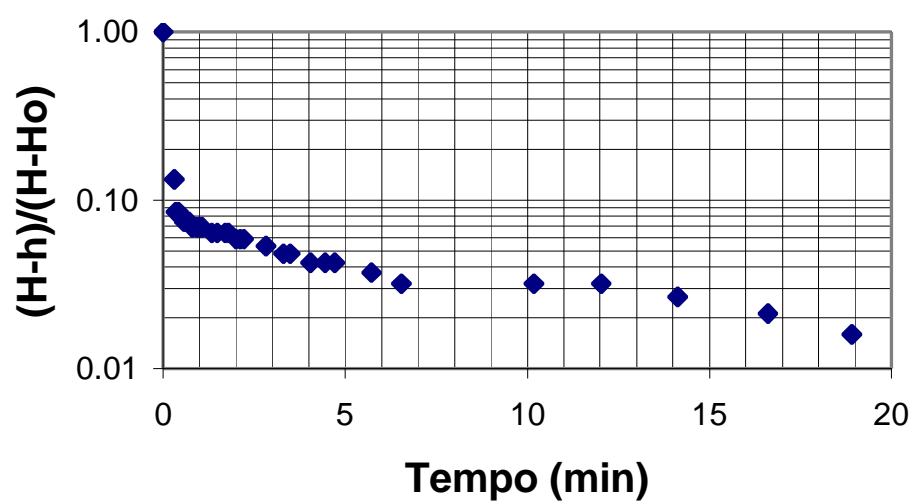

Figura A.13 Recuperação no poço P5 $T_{0}=0,2 \mathrm{~min}$ 
Tabela A.29 Teste slug no poço P6

\begin{tabular}{|c|c|c|}
\hline \multicolumn{3}{|c|}{ Tempo (min) Nível d' água (m) (H-h)/(H-Ho) } \\
\hline 0,00 & 5,679 & 1,001 \\
\hline 0,55 & 5,588 & 0,492 \\
\hline 0,82 & 5,568 & 0,380 \\
\hline 0,85 & 5,560 & 0,335 \\
\hline 0,97 & 5,564 & 0,358 \\
\hline 1,05 & 5,558 & 0,324 \\
\hline 1,12 & 5,557 & 0,318 \\
\hline 1,17 & 5,556 & 0,313 \\
\hline 1,22 & 5,553 & 0,296 \\
\hline 1,28 & 5,553 & 0,296 \\
\hline 1,33 & 5,552 & 0,291 \\
\hline 1,40 & 5,550 & 0,279 \\
\hline 1,45 & 5,550 & 0,279 \\
\hline 1,50 & 5,548 & 0,268 \\
\hline 1,55 & 5,545 & 0,251 \\
\hline 1,60 & 5,544 & 0,246 \\
\hline 1,67 & 5,543 & 0,240 \\
\hline 1,72 & 5,542 & 0,235 \\
\hline 1,80 & 5,539 & 0,218 \\
\hline 1,87 & 5,539 & 0,218 \\
\hline 1,92 & 5,539 & 0,218 \\
\hline 1,97 & 5,539 & 0,218 \\
\hline 2,03 & 5,539 & 0,218 \\
\hline 2,12 & 5,534 & 0,190 \\
\hline 2,17 & 5,534 & 0,190 \\
\hline 2,25 & 5,534 & 0,190 \\
\hline 2,30 & 5,533 & 0,184 \\
\hline 2,37 & 5,532 & 0,179 \\
\hline 2,42 & 5,531 & 0,173 \\
\hline 2,50 & 5,531 & 0,173 \\
\hline 2,57 & 5,529 & 0,162 \\
\hline 2,63 & 5,529 & 0,162 \\
\hline 2,67 & 5,530 & 0,168 \\
\hline 2,87 & 5,530 & 0,168 \\
\hline 2,97 & 5,529 & 0,162 \\
\hline 3,20 & 5,528 & 0,156 \\
\hline 3,28 & 5,525 & 0,140 \\
\hline 3,47 & 5,523 & 0,128 \\
\hline 3,57 & 5,520 & 0,112 \\
\hline 3,80 & 5,517 & 0,095 \\
\hline 4,02 & 5,517 & 0,095 \\
\hline 5,17 & 5,515 & 0,084 \\
\hline 5,65 & 5,510 & 0,056 \\
\hline 6,10 & 5,503 & 0,017 \\
\hline 6,30 & 5,502 & 0,011 \\
\hline 6,63 & 5,502 & 0,011 \\
\hline 6,83 & 5,501 & 0,006 \\
\hline
\end{tabular}

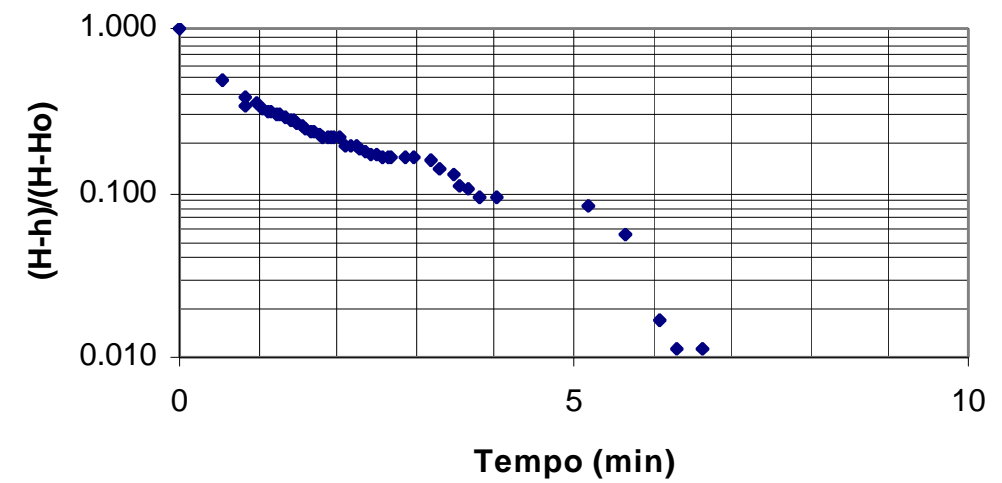

Figura A.14 Recuperação no poço P6 $T_{0}=0,9 \mathrm{~min}$ 
Tabela A.30 Teste slug no poço P7

\begin{tabular}{ccc}
\hline $\begin{array}{c}\text { TempoNível d' água(H-h)/(H-Ho) } \\
\text { (min) }\end{array}$ & $(\mathrm{m})$ & \\
\hline 0,00 & 3,968 & 1,001 \\
0,23 & 3,875 & 0,505 \\
0,30 & 3,860 & 0,426 \\
0,35 & 3,850 & 0,372 \\
0,38 & 3,841 & 0,324 \\
0,43 & 3,836 & 0,298 \\
0,48 & 3,831 & 0,271 \\
0,52 & 3,821 & 0,218 \\
0,57 & 3,813 & 0,176 \\
0,62 & 3,807 & 0,144 \\
0,67 & 3,803 & 0,122 \\
0,72 & 3,803 & 0,122 \\
0,75 & 3,800 & 0,106 \\
0,80 & 3,796 & 0,085 \\
0,85 & 3,792 & 0,064 \\
0,90 & 3,790 & 0,053 \\
0,93 & 3,789 & 0,048 \\
0,98 & 3,789 & 0,048 \\
1,02 & 3,788 & 0,043 \\
1,10 & 3,786 & 0,032 \\
1,15 & 3,785 & 0,027 \\
1,20 & 3,785 & 0,027 \\
1,28 & 3,784 & 0,021 \\
1,35 & 3,783 & 0,016 \\
1,40 & 3,782 & 0,011 \\
\hline & &
\end{tabular}

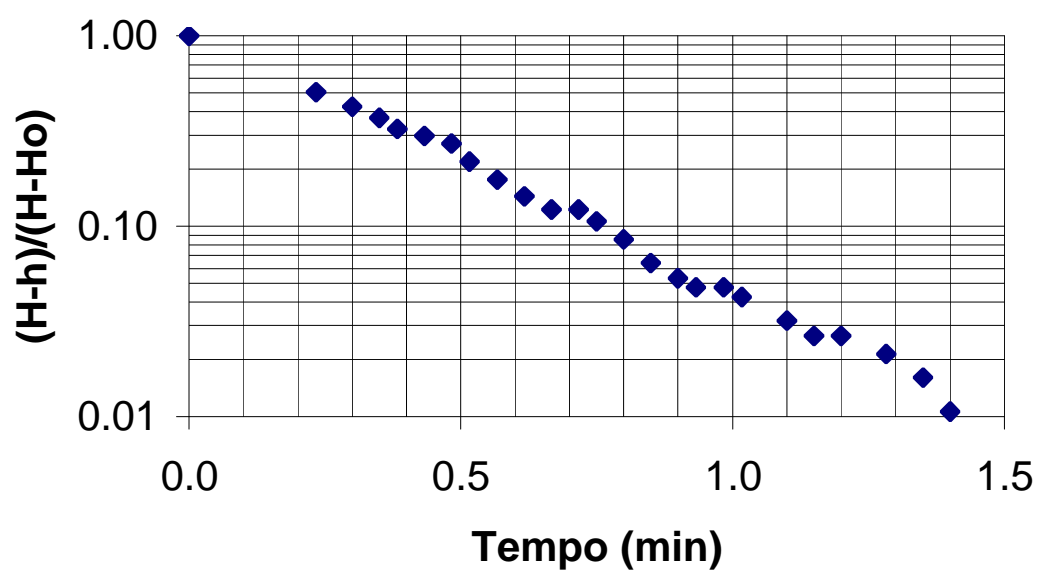

Figura A.15 Recuperação no poço P7 $T_{0}=0,37 \mathrm{~min}$ 
Tabela A.31 Teste slug no poço P8

\begin{tabular}{|c|c|c|}
\hline \multicolumn{3}{|c|}{$\begin{array}{l}\text { TempoNível d' água }(\mathrm{H}-\mathrm{h}) /(\mathrm{H}-\mathrm{Ho}) \\
(\min ) \\
\begin{array}{ll}(\mathrm{m}) \\
\end{array}\end{array}$} \\
\hline 0,00 & 5,268 & 1,001 \\
\hline 0,63 & 5,311 & 1,229 \\
\hline 0,75 & 5,307 & 1,207 \\
\hline 0,88 & 5,295 & 1,144 \\
\hline 0,98 & 5,291 & 1,122 \\
\hline 1,08 & 5,281 & 1,067 \\
\hline 1,20 & 5,280 & 1,065 \\
\hline 1,32 & 5,277 & 1,048 \\
\hline 1,38 & 5,270 & 1,011 \\
\hline 1,50 & 5,268 & 1,000 \\
\hline 1,67 & 5,260 & 0,957 \\
\hline 1,85 & 5,256 & 0,936 \\
\hline 2,02 & 5,245 & 0,878 \\
\hline 2,17 & 5,240 & 0,851 \\
\hline 2,28 & 5,235 & 0,824 \\
\hline 2,47 & 5,231 & 0,803 \\
\hline 2,60 & 5,225 & 0,771 \\
\hline 2,72 & 5,222 & 0,755 \\
\hline 2,82 & 5,218 & 0,734 \\
\hline 3,00 & 5,213 & 0,707 \\
\hline 3,17 & 5,207 & 0,676 \\
\hline 3,33 & 5,205 & 0,665 \\
\hline 3,53 & 5,199 & 0,633 \\
\hline 3,75 & 5,192 & 0,596 \\
\hline 4,10 & 5,181 & 0,535 \\
\hline 4,35 & 5,180 & 0,532 \\
\hline 4,75 & 5,173 & 0,495 \\
\hline 5,30 & 5,162 & 0,436 \\
\hline 6,12 & 5,150 & 0,372 \\
\hline 6,75 & 5,142 & 0,330 \\
\hline 7,70 & 5,129 & 0,261 \\
\hline 8,17 & 5,126 & 0,245 \\
\hline 8,90 & 5,119 & 0,207 \\
\hline 9,58 & 5,114 & 0,181 \\
\hline 11,13 & 5,105 & 0,133 \\
\hline 13,00 & 5,097 & 0,090 \\
\hline 14,62 & 5,092 & 0,064 \\
\hline 16,43 & 5,089 & 0,048 \\
\hline 18,80 & 5,084 & 0,021 \\
\hline
\end{tabular}

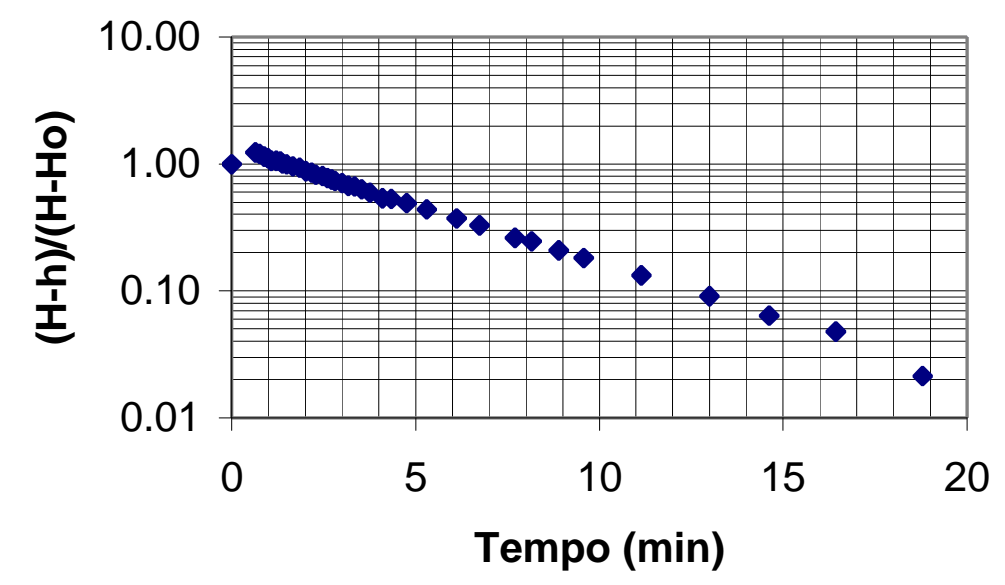

Figura A.16 Recuperação no poço P8 $T_{0}=5,8 \mathrm{~min}$ 
Tabela A.32 Teste slug no poço P9

\begin{tabular}{|c|c|c|}
\hline \multicolumn{3}{|c|}{ Tempo (min) Nível d' água (m) (H-h)/(H-Ho) } \\
\hline 0,00 & 4,759 & 1,001 \\
\hline 0,40 & 4,718 & 0,771 \\
\hline 0,50 & 4,712 & 0,737 \\
\hline 0,60 & 4,709 & 0,721 \\
\hline 0,72 & 4,705 & 0,698 \\
\hline 0,80 & 4,703 & 0,687 \\
\hline 0,87 & 4,699 & 0,665 \\
\hline 0,95 & 4,696 & 0,648 \\
\hline 1,03 & 4,692 & 0,626 \\
\hline 1,17 & 4,689 & 0,609 \\
\hline 1,25 & 4,686 & 0,592 \\
\hline 1,33 & 4,683 & 0,575 \\
\hline 1,43 & 4,680 & 0,559 \\
\hline 1,52 & 4,679 & 0,553 \\
\hline 1,62 & 4,676 & 0,536 \\
\hline 1,68 & 4,674 & 0,525 \\
\hline 1,78 & 4,673 & 0,520 \\
\hline 1,85 & 4,670 & 0,503 \\
\hline 1,93 & 4,669 & 0,497 \\
\hline 1,98 & 4,667 & 0,486 \\
\hline 2,05 & 4,665 & 0,475 \\
\hline 2,13 & 4,663 & 0,464 \\
\hline 2,30 & 4,660 & 0,447 \\
\hline 2,63 & 4,656 & 0,425 \\
\hline 2,75 & 4,654 & 0,413 \\
\hline 2,95 & 4,650 & 0,391 \\
\hline 3,07 & 4,649 & 0,385 \\
\hline 3,22 & 4,648 & 0,380 \\
\hline 3,37 & 4,647 & 0,374 \\
\hline 3,55 & 4,644 & 0,358 \\
\hline 3,88 & 4,640 & 0,335 \\
\hline 4,03 & 4,639 & 0,330 \\
\hline 4,17 & 4,638 & 0,324 \\
\hline 4,27 & 4,636 & 0,313 \\
\hline 4,40 & 4,634 & 0,302 \\
\hline 4,50 & 4,633 & 0,296 \\
\hline 5,00 & 4,630 & 0,279 \\
\hline 6,47 & 4,622 & 0,235 \\
\hline 7,72 & 4,616 & 0,201 \\
\hline 10,57 & 4,613 & 0,184 \\
\hline 12,83 & 4,610 & 0,168 \\
\hline 14,65 & 4,609 & 0,162 \\
\hline 18,18 & 4,608 & 0,156 \\
\hline 21,10 & 4,607 & 0,151 \\
\hline 25,40 & 4,605 & 0,140 \\
\hline 35,62 & 4,603 & 0,128 \\
\hline 46,80 & 4,603 & 0,128 \\
\hline
\end{tabular}

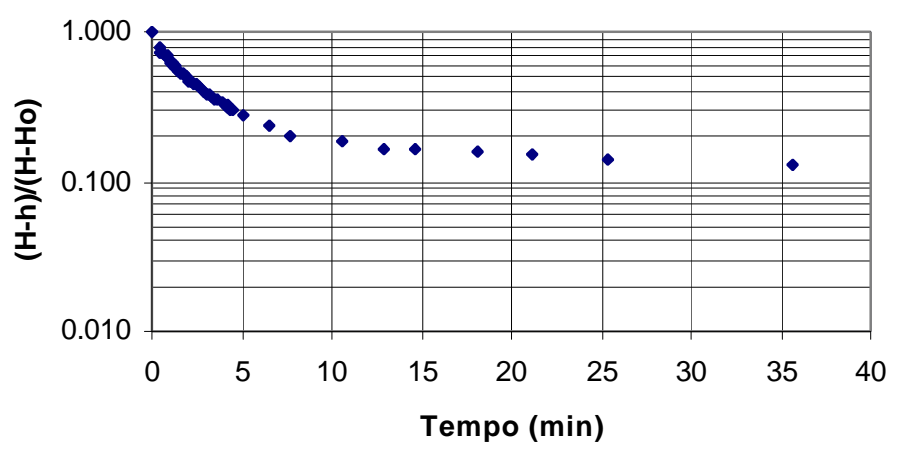

Figura A.17 Recuperação no poço P9 $T_{0}=3,0 \mathrm{~min}$ 
Tabela A.33 Teste slug no poço P10

\begin{tabular}{ccc}
\hline \multirow{2}{*}{$\begin{array}{c}\text { TempoNível d' água(H-h)/(H-Ho) } \\
\text { (min) }\end{array}$} & $(\mathrm{m})$ & \\
\hline 0,00 & 2,958 & 1,001 \\
0,33 & 2,883 & 0,601 \\
0,43 & 2,855 & 0,452 \\
0,53 & 2,836 & 0,351 \\
0,62 & 2,827 & 0,303 \\
0,67 & 2,820 & 0,266 \\
0,72 & 2,816 & 0,245 \\
0,82 & 2,806 & 0,191 \\
0,90 & 2,802 & 0,170 \\
0,97 & 2,797 & 0,144 \\
1,03 & 2,797 & 0,144 \\
1,12 & 2,793 & 0,122 \\
1,18 & 2,791 & 0,112 \\
1,25 & 2,790 & 0,106 \\
1,33 & 2,786 & 0,085 \\
1,40 & 2,785 & 0,080 \\
1,53 & 2,781 & 0,059 \\
1,62 & 2,780 & 0,053 \\
1,73 & 2,778 & 0,043 \\
1,83 & 2,777 & 0,037 \\
1,92 & 2,776 & 0,032 \\
2,05 & 2,775 & 0,027 \\
2,12 & 2,774 & 0,021 \\
2,20 & 2,774 & 0,021 \\
2,27 & 2,774 & 0,021 \\
2,47 & 2,773 & 0,016 \\
2,57 & 2,772 & 0,011 \\
\hline & &
\end{tabular}

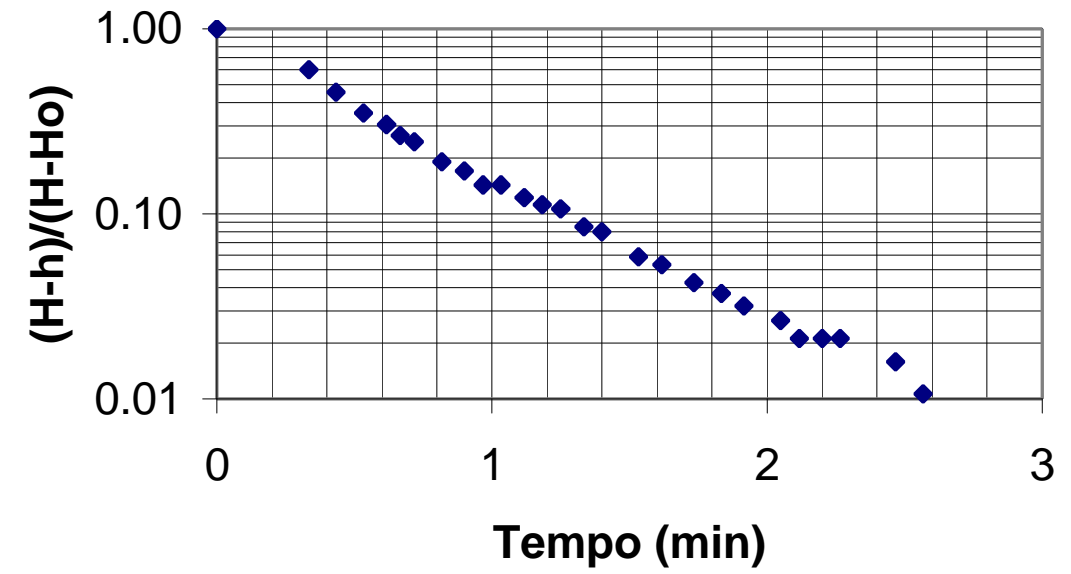

Figura A.18 Recuperação no poço P10 $T_{0}=0,59 \mathrm{~min}$ 
Tabela A.34 Teste slug no poço P12

\begin{tabular}{crr}
\hline $\begin{array}{c}\text { TempoNível d' água(H-h)/(H-Ho) } \\
\text { (min) }\end{array}$ & $(\mathrm{m})$ & \\
\hline 0,00 & 5,009 & 1,001 \\
1,38 & 5,000 & 0,950 \\
1,68 & 5,000 & 0,950 \\
1,75 & 5,000 & 0,950 \\
1,87 & 4,998 & 0,939 \\
2,07 & 4,998 & 0,939 \\
2,23 & 4,998 & 0,939 \\
2,32 & 4,998 & 0,939 \\
2,45 & 4,998 & 0,939 \\
2,65 & 4,997 & 0,933 \\
3,40 & 4,996 & 0,927 \\
3,98 & 4,996 & 0,927 \\
4,48 & 4,996 & 0,927 \\
5,67 & 4,995 & 0,922 \\
7,50 & 4,995 & 0,922 \\
8,70 & 4,994 & 0,916 \\
12,08 & 4,994 & 0,916 \\
15,47 & 4,993 & 0,911 \\
18,93 & 4,992 & 0,905 \\
22,00 & 4,992 & 0,905 \\
27,17 & 4,991 & 0,899 \\
34,45 & 4,990 & 0,894 \\
39,12 & 4,989 & 0,888 \\
42,50 & 4,989 & 0,888 \\
\hline & &
\end{tabular}

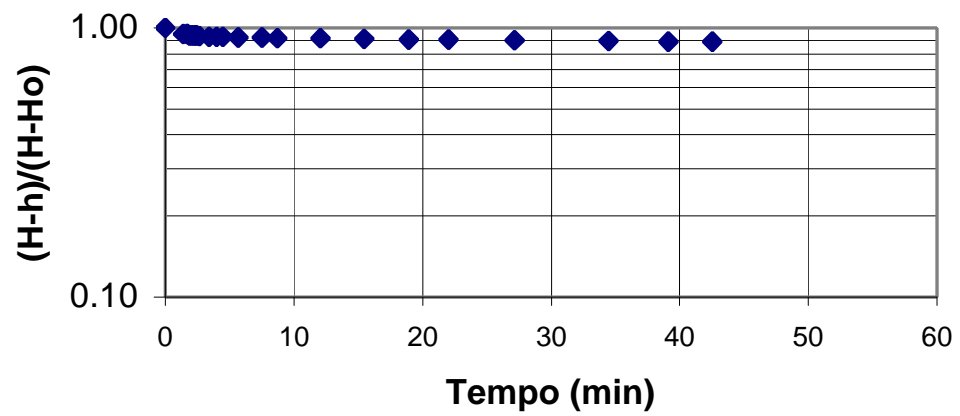

Figura A.19 Recuperação no poço P12

$T_{0}=381 \mathrm{~min}$ 
Tabela A.35 Teste slug no poço P13

\begin{tabular}{|c|c|c|}
\hline \multicolumn{3}{|c|}{$\begin{array}{l}\text { TempoNível d' água }(\mathrm{H}-\mathrm{h}) /(\mathrm{H}-\mathrm{Ho}) \\
\begin{array}{ll}(\min ) & (\mathrm{m})\end{array}\end{array}$} \\
\hline 0.00 & 4.638 & 1.001 \\
\hline 0.50 & 4.647 & 1.048 \\
\hline 0.60 & 4.649 & 1.059 \\
\hline 0.75 & 4.648 & 1.053 \\
\hline 0.90 & 4.648 & 1.053 \\
\hline 1.07 & 4.648 & 1.053 \\
\hline 1.93 & 4.648 & 1.053 \\
\hline 2.10 & 4.647 & 1.048 \\
\hline 2.25 & 4.647 & 1.048 \\
\hline 2.60 & 4.647 & 1.048 \\
\hline 3.03 & 4.647 & 1.048 \\
\hline 4.42 & 4.647 & 1.048 \\
\hline 5.72 & 4.647 & 1.048 \\
\hline 9.75 & 4.645 & 1.037 \\
\hline 14.03 & 4.645 & 1.037 \\
\hline 18.13 & 4.644 & 1.032 \\
\hline 23.42 & 4.643 & 1.027 \\
\hline 29.02 & 4.641 & 1.016 \\
\hline 35.20 & 4.639 & 1.005 \\
\hline 44.60 & 4.637 & 0.995 \\
\hline 52.33 & 4.636 & 0.989 \\
\hline 59.17 & 4.633 & 0.973 \\
\hline
\end{tabular}

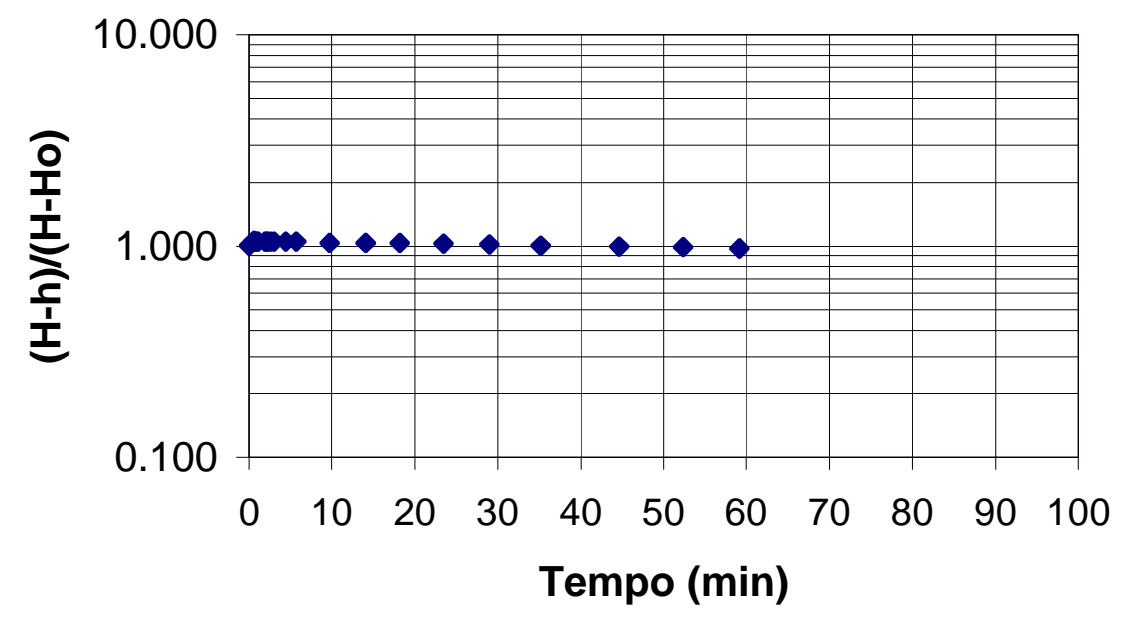

Figura A.20 Recuperação no poço P13

$T_{0}=650 \mathrm{~min}$ 
Tabela A.36 Teste slug no poço P15

\begin{tabular}{crr}
\hline \multicolumn{3}{c}{ TempoNível d' água(H-h)/(H-Ho) } \\
(min) & (m) & \multicolumn{1}{c}{$(\mathrm{m})$} \\
\hline 0,00 & 2,909 & 1,001 \\
0,57 & 2,912 & 1,017 \\
0,80 & 2,909 & 1,000 \\
0,93 & 2,909 & 1,000 \\
1,07 & 2,910 & 1,006 \\
1,22 & 2,909 & 1,000 \\
1,32 & 2,909 & 1,000 \\
1,47 & 2,909 & 1,000 \\
3,83 & 2,909 & 1,000 \\
6,32 & 2,906 & 0,983 \\
9,33 & 2,905 & 0,978 \\
13,45 & 2,904 & 0,972 \\
19,05 & 2,902 & 0,961 \\
22,67 & 2,900 & 0,950 \\
29,30 & 2,897 & 0,933 \\
35,35 & 2,896 & 0,927 \\
39,93 & 2,895 & 0,922 \\
45,00 & 2,892 & 0,905 \\
\hline
\end{tabular}

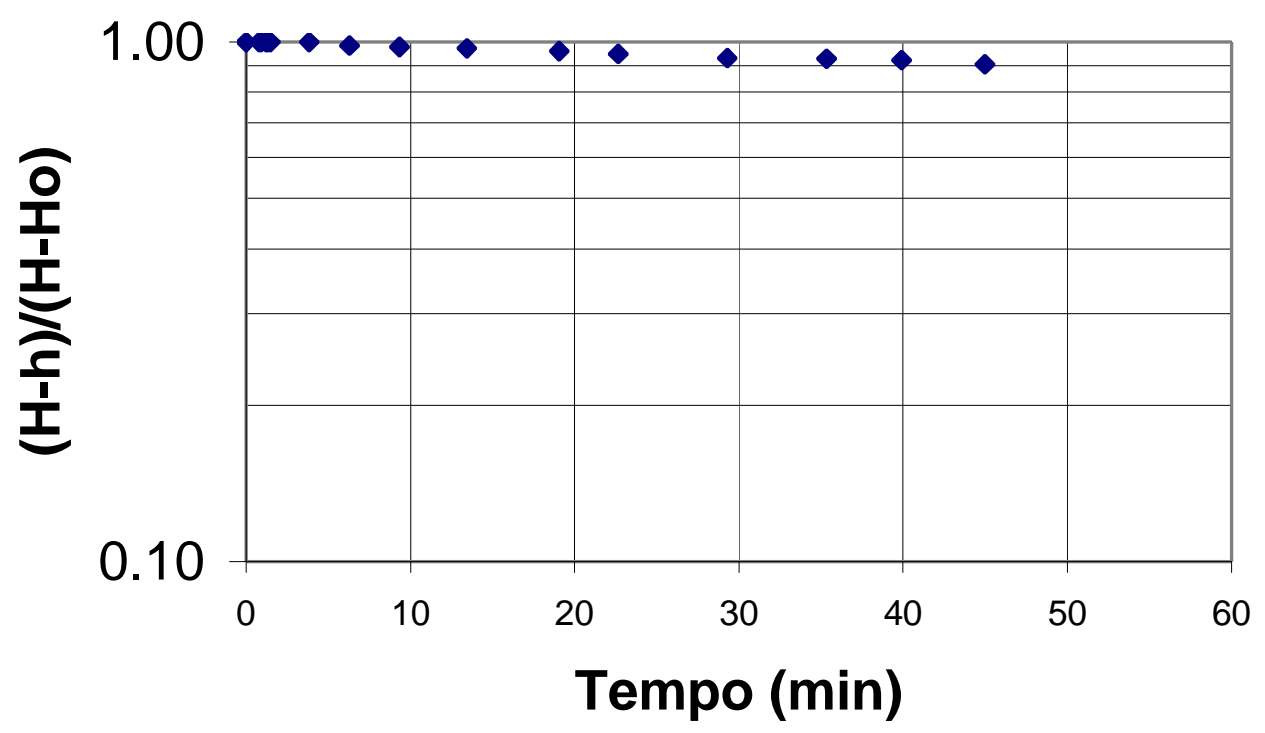

Figura A.21 Recuperação no poço P15

$T_{0}=368 \mathrm{~min}$ 
Tabela A.37 Teste slug no poço P16

\begin{tabular}{|c|c|c|}
\hline \multicolumn{3}{|c|}{$\overline{\text { TempoNível d' água(H-h)/(H-Ho) }}$} \\
\hline$(\min )$ & $(\mathrm{m})$ & $(\mathrm{m})$ \\
\hline 0,00 & 3,439 & 1,001 \\
\hline 0,53 & 3,434 & 0,972 \\
\hline 0,63 & 3,434 & 0,972 \\
\hline 0,78 & 3,433 & 0,966 \\
\hline 0,95 & 3,432 & 0,961 \\
\hline 1,10 & 3,432 & 0,961 \\
\hline 1,40 & 3,430 & 0,950 \\
\hline 2,25 & 3,429 & 0,944 \\
\hline 4,25 & 3,429 & 0,944 \\
\hline 9,07 & 3,428 & 0,939 \\
\hline 15,57 & 3,426 & 0,927 \\
\hline 21,88 & 3,423 & 0,911 \\
\hline 28,15 & 3,421 & 0,899 \\
\hline 33,00 & 3,420 & 0,894 \\
\hline 39,63 & 3,418 & 0,883 \\
\hline 44,67 & 3,416 & 0,872 \\
\hline 49,83 & 3,415 & 0,866 \\
\hline
\end{tabular}

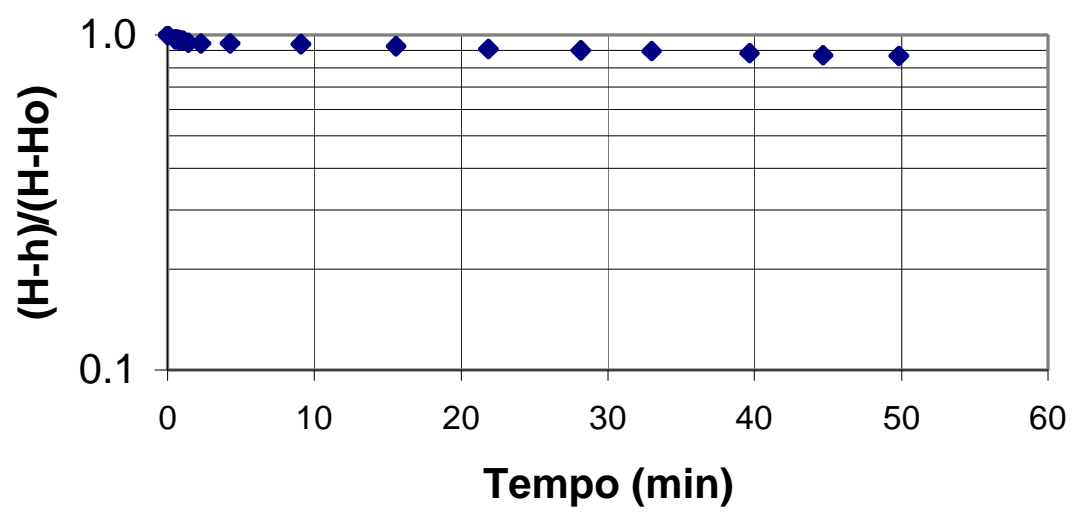

Figura A.22 Recuperação no poço P16 $T_{0}=350 \mathrm{~min}$ 
Tabela A.38 Teste slug no poço P19

\begin{tabular}{crr}
\hline $\begin{array}{c}\text { TempoNível d' água(H-h)/(H-Ho) } \\
(\mathrm{min})\end{array}$ & $(\mathrm{m})$ & \multicolumn{1}{c}{$(\mathrm{m})$} \\
\hline 0,00 & 4,349 & 1,001 \\
0,52 & 4,335 & 0,922 \\
0,72 & 4,334 & 0,916 \\
1,07 & 4,330 & 0,894 \\
1,37 & 4,329 & 0,888 \\
2,13 & 4,328 & 0,883 \\
3,43 & 4,326 & 0,872 \\
4,87 & 4,324 & 0,860 \\
6,25 & 4,324 & 0,860 \\
9,73 & 4,324 & 0,860 \\
12,53 & 4,322 & 0,849 \\
17,63 & 4,321 & 0,844 \\
22,82 & 4,319 & 0,832 \\
27,98 & 4,317 & 0,821 \\
34,43 & 4,317 & 0,821 \\
40,00 & 4,314 & 0,804 \\
45,73 & 4,313 & 0,799 \\
\hline
\end{tabular}

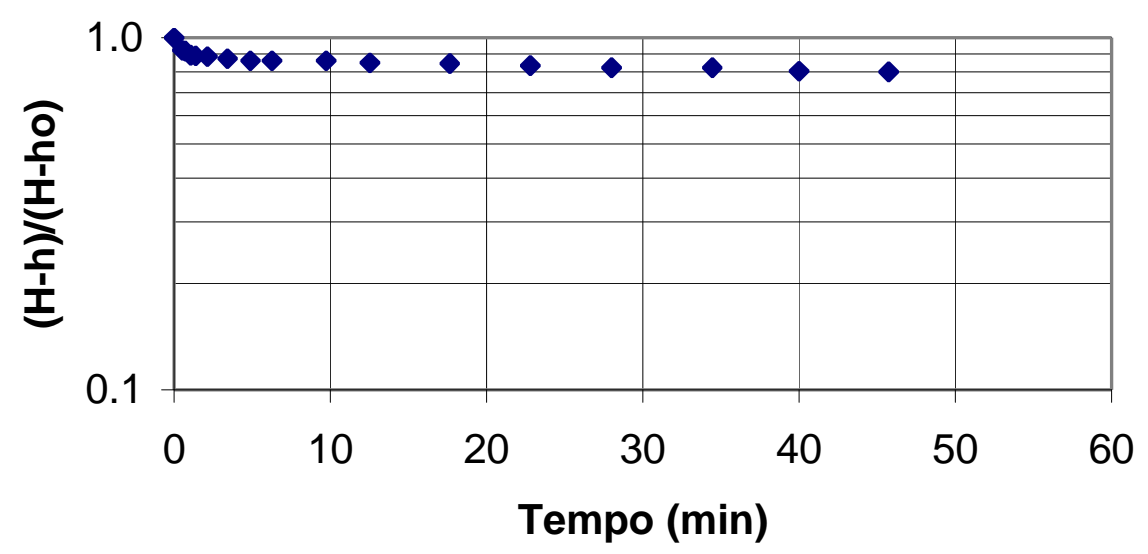

Figura A.23 Recuperação no poço P19

$T_{0}=261 \mathrm{~min}$ 
Nome do arquivo: ANEXOFINAL

Pasta: $\quad$ C:IDocuments and SettingslclientelConfigurações locais $\backslash$ Temporary Internet Files\Content.IE5\6XUTO3SN

Modelo: $\quad$ C:IDocuments and SettingslclientelDados de aplicativos Microsoft $M$ Modelos $\backslash$ Normal.dot

Título:

RESULTADOS

Assunto:

Autor: $\quad$ Bolivar Antunes Matos

Palavras-chave:

Comentários:

Data de criação: $\quad$ 10/4/2001 08:18

Número de alterações:4

Última gravação: $\quad$ 10/4/2001 08:24

Gravado por: Bolivar Antunes Matos

Tempo total de edição: $\quad 8$ Minutos

Última impressão: $\quad$ 27/1/2001 16:40

Como a última impressão

Número de páginas: $\quad 47$

Número de palavras: $\quad 5.884$ (aprox.)

Número de caracteres: 33.542 (aprox.) 